
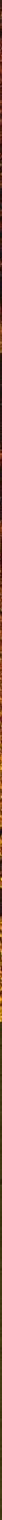

Exile and Displacement in Late Antiquity

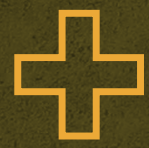

JENNIFER BARRY 


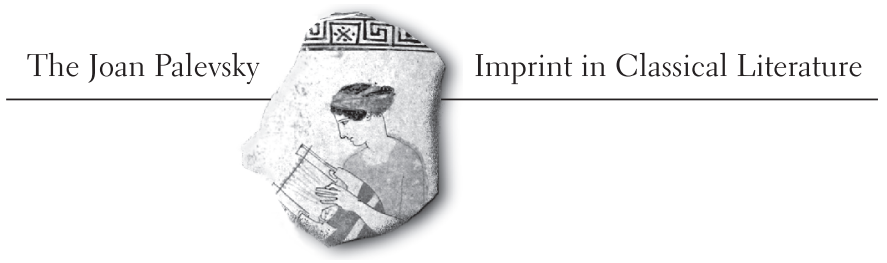

In honor of beloved Virgil_-

"O degli altri poeti onore e lume ..."

-Dante, Inferno 
The publisher and the University of California Press Foundation gratefully acknowledge the generous support of the Joan Palevsky Imprint in Classical Literature 
Bishops in Flight 
Luminos is the Open Access monograph publishing program from UC Press. Luminos provides a framework for preserving and reinvigorating monograph publishing for the future and increases the reach and visibility of important scholarly work. Titles published in the UC Press Luminos model are published with the same high standards for selection, peer review, production, and marketing as those in our traditional program. www.luminosoa.org 


\section{Bishops in Flight}

Exile and Displacement in Late Antiquity

Jennifer Barry

哩

UNIVERSITY OF CALIFORNIA PRESS 
University of California Press, one of the most distinguished university presses in the United States, enriches lives around the world by advancing scholarship in the humanities, social sciences, and natural sciences. Its activities are supported by the UC Press Foundation and by philanthropic contributions from individuals and institutions. For more information, visit www.ucpress.edu.

University of California Press

Oakland, California

(C) 2019 by Jennifer Barry

This work is licensed under a Creative Commons CC BY-SA license. To view a copy of the license, visit http://creativecommons.org/licenses.

Suggested citation: Barry, J. Bishops in Flight: Exile and Displacement in Late Antiquity. Oakland: University of California Press, 2019.

DOI: https://doi.org/10.1525/luminos.69

Library of Congress Cataloging-in-Publication Data.

Names: Barry, Jennifer, 1982- author.

Title: Bishops in flight : exile and displacement in late antiquity / Jennifer Barry.

Description: Oakland, California : University of California Press, [2019] | Includes bibliographical references and index. |

Identifiers: LCCN 2018047795 (print) | LCCN 2019012027 (ebook) | ISBN 9780520971806 () | ISBN 9780520300378 (pbk. : alk. paper)

Subjects: LCSH: Bishops--Rome--History--Early church, ca. 30-6oo. | Persecution--History--Early church, ca. 30-600. | Exiles--Rome-History. | Exile (Punishment)--Rome. | Athanasius, Saint, Patriarch of Alexandria, -373. | John Chrysostom, Saint, -407.

Classification: LCC BR1604.23 (ebook) | LCC BR1604.23 .B37 2019 (print) | DDC $273 / .4--\mathrm{dc} 23$

LC record available at https://lccn.loc.gov/2018047795

$\begin{array}{lllllllll}27 & 26 & 25 & 24 & 23 & 22 & 21 & 20 & 19\end{array}$

$\begin{array}{llllllllll}10 & 9 & 8 & 7 & 6 & 5 & 4 & 3 & 2 & 1\end{array}$ 
For Bernie (1990-2016) 

CONTENTS

Prologue xiii

Abbreviations xvii

INTRODUCTION

The Discourse of Flight 2

Explorations of Exile $\quad 5$

Episcopal Exile $\quad 9$

Models of Exile 11

$\begin{array}{ll}\text { Heresiology and Exile } & 17\end{array}$

Episcopal Exile and Displacement $\quad 22$

$\begin{array}{ll}\text { Outline of Book } & 26\end{array}$

1. ATHANASIUS OF ALEXANDRIA IN FLIGHT 31

How to Construct a Model City: Alexandria 32

If These Walls Could Talk: Defense Before Constantius 37

A Wall-Less Desert: Defense of His Flight 44

A Model City without Walls: Life of Antony 49

Conclusion $\quad 54$ 
2. HOW TO RETURN FROM FLIGHT

How to Rehabilitate a Failed Bishop: Gregory of Nazianzus 57

How to Construct a Model City: Constantinople 59

A Model Exile: In Praise of Basil the Great 64

A Model Return: In Praise of Athanasius 69

$\begin{array}{ll}\text { Conclusion } & 74\end{array}$

3. JOHN CHRYSOSTOM IN FLIGHT 76

A Man in Flight: John Chrysostom 77

How to Construct a Model City: Antioch 79

Bishops Who Die in Flight: Meletius of Antioch 81

How Not to Flee: Theophilus of Alexandria 84

Bishops Who Do Not Return $\quad 92$

$\begin{array}{ll}\text { Conclusion } & 100\end{array}$

4. TO REHABILITATE AND RETURN A BISHOP IN FLIGHT 103

How to Diagnose Exile: Ps.-Martyrius's Funerary Speech 105

How to Interpret Exile: Palladius of Helenopolis's Dialogue on the

Life of John Chrysostom 119

How to Return from Exile: Athanasius and John Chrysostom 124

$\begin{array}{ll}\text { Conclusion } & 130\end{array}$

5. TO CONDEMN A BISHOP IN FLIGHT 132

How to Condemn a Model City: Nicomedia 133

An Unorthodox Return from Flight: Eusebius of Nicomedia 136

How to Rehabilitate a Bishop: Philostorgius of Cappadocia's

Ecclesiastical History 139

How to Condemn a Model Exile: Socrates of Constantinople's

Ecclesiastical History 141

How to Rehabilitate a Condemned City: Theodoret of Cyrrhus's

$\begin{array}{ll}\text { Ecclesiastical History } & 148\end{array}$

$\begin{array}{ll}\text { Conclusion } & 151\end{array}$ 
6. REMEMBERING EXILE

Remembering a Not-So-Model City: Antioch

Martyrs and Bishops in Flight

How to Remember Orthodox Flight: Sozomen of Constantinople's Ecclesiastical History 161

Competing Memories: Socrates and Sozomen 167

Conclusion

Epilogue

173

Bibliography

179

Index

195 

Many thanks go first and foremost to Robert McGrath, who saw this project at various stages. As a close reader of this dissertation turned monograph, he has been a wonderful help and source of strength through it all. There aren't enough words to say thank you. I love you, Rob. I would also like to acknowledge my two children, who bookend this project. Laura, who was born at the start of my graduate studies, and Leighton, who was born at the end of the editorial process, offered their mother the discipline and motivation to finish this book. I would also like to thank my Doktormutter, Virginia Burrus, whose tireless patience and invaluable feedback both challenged and significantly improved my research and writing at each phase of this project. Virginia, your ongoing confidence in my work has pushed me to strive for excellence continuously. I am also indebted to the other members on my dissertation committee, Melanie Johnson-DeBaufre and Catherine Peyroux, whose comments helped me to envision where the project could go. My graduate school colleagues were also instrumental in the early stages of my research. Many thanks are due to my Drew University cohort, including my dearest friend, Peter Mena. I am also thankful for the support provided by my early graduate school writing-group members and fellow academic mothers Shanell Smith and Kathleen Gallagher Elkins. I also owe a great deal to the kindness and friendship shown to me by my colleagues Minta Fox, Matthew Ketchum, Dhawn Martin, Geoff Pollick, David Evans, Jennifer Kaalund, Natalie Williams, and Christy Cobb. The writing process was often an alienating experience, but I was often encouraged and supported by those collegial friendships that extended beyond my graduate institution. Many thanks to Maia Kotrosits, Christine Luckritz Marquis, C. Mike Chin, Kristi Upson-Saia, Susanna Drake, Blossom Stefaniw, 
Carrie Schroeder, Dana Robinson, Todd Berzon, Mike Azar, Jon Stanfill, Phil Webster, Phillip Fackler, John Penniman (PH), and Eric Daryl Meyer.

I would also like to thank another informal mentor, Andrew Jacobs, who was instrumental in helping me transition this project from dissertation to book. Your thorough feedback and ongoing collegial guidance have helped me on more than one occasion. The support offered by both Ellen Muehlberger and Mira Balberg while I was at the University of Michigan provided me with much of the confidence needed to see this project forward at a very uncertain stage in my career. Ellen, in particular, I remain indebted to you for your ceaseless mentorship and ongoing example of academic integrity and kindness. I would also like to thank Julia Hillner and Sarah Bond whose constant willingness to collaborate helped me to imagine new ways and methods to explore exile in late antiquity. I have learned a great deal from the other members of the Migrations of Faith: Clerical Exile in Late Antiquity Project as well, including Eric Fournier, David M. Reis, Margarita Vallejo Girves, and David Natal.

This book project has, of course, evolved and changed over time. My research and ideas could not have come about without the time and effort taken by many of my colleagues who have discussed, read, advised, edited, or commented on early chapters or drafts, such as Wendy Mayer, Angela Erisman, Eric Schmidt, Kathryn Yahner, Stephanie Cobb, David Eastman, Kate Cooper, Becky Krawiec, Ben Dunning, Richard Flower, Robin Whelan, Christopher Frilingos, Bradley K. Storin, Mark Delgoliano, J. Warren Smith, Susanna Elm, Taylor Petrey, Chris De Wet, Heidi Marx, Annette Yoshiko Reed, Candida Moss, Elizabeth Castelli, Elizabeth Clark, Jim Goehring, David Brakke, and David Maldonado-Rivera. My nonacademic relationships were also instrumental, and I would like to thank Caroline Dyer for running alongside me throughout this marathon of a project.

And, finally, I owe a great deal; to my wonderful mother, Ellen Barry; to my father, John Barry, and his wife, Mary Ellen Barry; to my brother, Johnny, and sister-in-law, Emily Barry; and my supportive in-laws, Mary McGrath and Bob McGrath. I could not have finished this book without all their love and assistance through various means, such as childcare, financial support, and constant encouragement. 


\section{PROLOGUE}

For if persecution proceeds from God, in no way will it be our duty to flee from what has God as its author; a twofold reason opposing; for what proceeds from God should not be avoided and it cannot be evaded.

-TERTULLIAN, ON FLIGHT IN PERSECUTION ${ }^{1}$

The Lord commanded us to withdraw and flee from persecution, and to encourage us to it. He both taught and did so Himself.

- CYPRIAN, ON THE LAPSED ${ }^{2}$

To flee during times of persecution is to deny Christ-or so Tertullian of Carthage (ca. 155-240) argued in On Flight in Persecution. Yet flight became an important part of the Christian legacy, even well after the official imperial persecution of Christians had ended. This book explores why the discourse of Christian flight became an important part of the narrative of pro-Nicene orthodoxy that would dominate the Roman Empire. Not only does Christian flight take precedence over memories of martyrdom, but the cultural authority of those bygone martyrs is also slowly folded into new persecution narratives of episcopal exile. As Athanasius of Alexandria (ca. 293-373) argued in the fourth century, the blood of the martyrs may indeed be the seed of the church, but the bishop-particularly the bishop who survives-ensures that the seed takes root. It is not the body of the martyr but the voice of the episcopal father that ensures the survival and the legacy of the church. Despite Athanasius's bold claims, made at a very different point in Christian history, flight during times of persecution would remain a troubling idea.

Tertullian insisted that persecution is possible only if God allows it. It is either a test for the faithful or a judgment passed on the unfaithful. In a moment of reflection, he posed a heuristic question, one that Athanasius would also ask: "Is it not be better to flee temporarily than to deny Christ and perish eternally?" Tertullian's response is a damning one: "Are you sure you will deny if you do not flee, or are you not sure? For if you are sure, you have denied already, because by presupposing that you will deny, you have given yourself up to that about which you have made such a presupposition; and now it is vain for you to think of flight, that you

1. Tertullian, Fug. 4.1. Edition: CSEL 76. Translation: ANF 4 unless otherwise noted.

2. Cyprian, Laps. 10. Edition: CSEL 3.1. Translation: ACW 25 unless otherwise noted. 
may avoid denying, when in intention you have denied already" (Tertullian, Fug. 5). In short, the one who flees is already guilty of the denial. In Tertullian's mind, actions speak louder than words.

As if this response was not clear enough, Tertullian anticipated a second question-should not a leader, such as a deacon, presbyter, or bishop, flee to preserve his life for the sake of his flock? - when he argued that, if one is truly a leader, it is better to give up one's life for one's flock than to lead the sheep astray. "But when persons in authority themselves-I mean the very deacons, and presbyters, and bishops - take to flight, how will a layman be able to see with what view it was said, Flee from city to city? Thus, too, with the leaders turning their backs, who of the common rank will hope to persuade men to stand firm in the battle? (Fug. 11). Tertullian's critique of flight highlights two points: First, flight is not permissible for true Christians. Second, not even Christian leaders are exempt from this mandate. Christian leaders are held to a higher standard and obliged to set an example for the community of believers.

At the heart of Tertullian's argument is the idea that flight is the external sign of an internal fault. Yet, by the fourth century, Athanasius would argue the exact opposite. He ardently defended episcopal flight, stating that it is not only evidence of Christian authenticity but also a sign of the devious nature of Christian persecution even after the imperial persecutions had ended. In a surprising move, given Tertullian's conclusions, Athanasius looked to pre-fourth-century examples of flight to point out the symptoms of persecution and further justify Christian flight. Not all martyrdoms, he concluded, take place in the arena. Those who suffer and survive prove his case.

When viewed against Tertullian, Athanasius appears to be a watershed, introducing a very different response to Christian persecution. That said, his definition of flight was not without historical precedent. In the aftermath of the emperor Decius's persecution in 250, the bishop Cyprian of Carthage (ca. 200-258) was faced with the challenge of rehabilitating members of the Christian community who had either denied Christ or chosen to flee rather than face torture and death. In On the Lapsed, he appears to follow the same logic set out by Tertullian above. He begins his treatise praising the memory of the martyrs and confessors who passed the divine test with their lives. He then quickly transitions into a lament for those who failed the same test (among whom he might be included): "Too many bishops, instead of giving encouragement and example to others, made no account of their being God's ministers, and became the ministers of earthly kings; they left their sees, abandoned their people, and toured the markets in other territories on the look-out for profitable deals" (Laps. 6). We readers are meant to compare these lamentable figures with those martyrs and confessors who willingly gave their lives. Certainly, these failed leaders should be deposed and their memories condemned-and we have ample evidence for communities, such as the Donatists and Novatians, who did just that. But Cyprian takes a slightly different approach 
when he begins to argue that not all flights were for personal gain. By combining the verbs secedere, "to withdraw," and fugere, "to flee," he states that some departures are permissible, even required: "The Lord commanded us to withdraw and flee from persecution, and to encourage us to it. He both taught and did so Himself" (Laps. 10). Cyprian's logic is as follows: If Christ fled to the desert because it was not yet his time, so too his followers ought to flee until their appointed time. Christian flight is a sign of fortitude, not of fault. True Christians, taking Christ as their example, flee.

Many early Christian martyr texts attempt to articulate the parameters around Christian flight by comparing their martyrs not only to Christ but also to exemplary heroes in classical texts. The "noble death" motif, for example, posed a significant problem for bishops like Cyprian and Athanasius, who found the charge of cowardice lurking behind their flight. ${ }^{3}$ As Stephanie Cobb has noted in her assessment of the Martyrdom of Polycarp, there is a significant number of literary allusions to the death of the famous Greek philosopher Socrates. The willingness of the martyr-bishop Polycarp to die a noble death rather than to flee was an intentional literary link to shore up his legitimacy as a classical hero. As Cobb notes, this imitatio Socratis alongside the imitatio Christi was a significant link. She writes: "Both men, for instance, were described as 'noble' ([Plato,] Phaed. 58D; Mart. Pol. 2.1), and they were both charged with atheism ([Plato,] Euth. 3B; Mart. Pol. 3.2.; 12.2). Socrates refused to flee Athens in order to save his life ([Plato,] Phaed. 98E-99A). Similarly, after receiving the vision that he must die, Polycarp refused to flee (Mart. Pol. 7.1)." 4 And while Polycarp did flee for a time (Mart. Pol. 5-6) - in order to stress that he did not seek out his martyrdom (unlike a failed martyr named Quintus) — this link to a longer tradition of "manly deaths" after a period of withdrawal reveals to what lengths authors must go to contextualize heroic acts of flight. ${ }^{5}$

By the fourth century, then, there was a well-established tradition that Christian authors would pull from to justify flight. And still, this new moment brought about significant challenges as the would-be martyr-bishop faced new adversaries-and ones that were no longer the imperial enemies of the earlier era. For late ancient Christian authors, this dilemma raised a pressing question: what happens when the enemies and heroes are no longer distinguishable? The one in flight could easily be seen as the hero or the enemy. A new script was handed to those Christians who

3. See L. Stephanie Cobb, "Polycarp's Cup: Imitatio in the Martyrdom of Polycarp," Journal of Religious History 38.2 (2014), 227n12. Many thanks to Stephanie Cobb and the other editorial readers of the "Inventing Christianity" series at Penn State Press for suggesting this article.

4. Cobb, "Polycarp's Cup," 227.

5. In a frequently cited passage, Polycarp is commanded to "play the man" (Mart. Pol. 9.1). This command is prevalent throughout martyrological texts. We find "manliness" here used to prop up Polycarp's decision to flee over and against Quintus, the cowardly martyr, who willingly sought out the glory of martyrdom only to fold under pressure (Mart. Pol. 4). 
continued to suffer imperial or, now, ecclesial persecution. How one identified the hero in the narrative of Christian triumph became its own battleground. ${ }^{6}$

Christian flight thus took on new discursive meanings that helped to define Christian orthodoxy. It became a rhetorical tool that would rival the cultural authority of the martyrs - so much so that, by the time Athanasius, who will play a central role in this book, transformed his many flights from Alexandria into a heroic tale of sacrifice and survival, he developed an exilic discourse that was easily folded into the Nicene debates of the fourth century. In the pages that follow, the reader will discover that this process was so successful that, by the fifth century, the mere mention of Athanasius's legacy as a triumphant bishop in flight became the standard by which Christian orthodoxy, specifically pro-Nicene orthodoxy, was measured. He both taught, and did so himself. And others would do the same.

6. This battle was particularly difficult to win, as Candida Moss has demonstrated in her assessment of martyrdom as a set of discursive practices that served early Christians as a way to articulate meaning and forge identities of persecution. See Candida Moss, Ancient Christian Martyrdom: Diverse Practices, Theologies, and Traditions (New Haven, CT: Yale University Press, 2012). 
ABBREVIATIONS

Ammianus Marcellinus, Res gest. Res Gestae

Athanasius, Apol. Const.

Defense before Constantius

- - Apol. sec.

Defense against the Arians

—, Ep. encyl.

Encyclical Letter

On the Councils

Letter to Dracontius

Festal Letters

Letter to Serapion concerning the Death of Arius

Defense of His Flight

History of the Arians

On the Incarnation

Index

Orations against the Arians

Life of Anthony

The City of God

Unfinished Work in Answer to Julian

Confessions

The Work of Monks

Cicero, De re pub.

On the Commonwealth

Tusculan Disputations

Theodosian Code

xvii 
Cyprian, Laps.

Dio Chrysostom, Exil.

Orat.

Diodorus Siculus, Hist.

Epiphanius, Pan.

Euripides, Her.

Eusebius of Caesarea, Eccl. Hist.

$\longrightarrow$, Vit. Const.

Evagrius, Ant.

Gregory of Nazianzus, Carm.

$\longrightarrow$ - Ep.

$\longrightarrow$, Orat.

Gregory of Nyssa, In Mel.

Gregory of Tours, Greg. Hist.

Herodotus, Hist.

Hilary of Poitiers, Contra Const.

$\longrightarrow$, De Syn.

Hippocrates, Acut.

$\longrightarrow$, Aer.

$\longrightarrow, A p h$.

Jerome, Chron.

$\longrightarrow$ Ep.

$\longrightarrow$, Vit. Paul.

John Cassian, Conlat.

$\longrightarrow$, De Incarn.

John Chrysostom, Bab.

$\longrightarrow$, Bab. Jul.

- Catech. illum.

$\longrightarrow$, Ep.

- Hom. Matt.

$\longrightarrow$, Melet.

Josephus, J.W.

Julian, Mis.

Julius, Ep.

Lactantius, Mort.

Mart. Pol.
On the Lapsed

On Exile

Orations

Library of History

Refutation of All Heresies

Herakles

Ecclesiastical History

Life of Constantine

Refutation

Poems

Letters

Orations

On Saint Meletus

History of the Franks

Histories

Against Constantius

On the Synods

Regimen of Acute Diseases

Airs, Waters, Places

On Aphorisms

Chronicles

Letters

Life of Saint Paul

The Conferences

On the Incarnation

On St. Babylas the Martyr

On Babylas against Julian and the Pagans

Homily on the Gospel of Matthew

Epistles

Homily on Matthew

On St. Meletius

Jewish War

Misopogon

Letters

Death of the Persecutors

Martyrdom of Polycarp 
Ovid, Her.

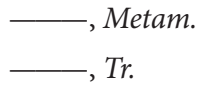

Palladius, Dia.

$\longrightarrow$, Laus. Hist.

Pausanias, Descr.

Plato, Apol.

$\longrightarrow$, Euth.

- Phaed.

Philo, Prob.

Philostorgius, Eccl. Hist.

Pliny, Nat.

Plutarch, Cons. Apoll. , Cons. ux.

Ps.-Apollodorus, Biblio.

Ps.-Martyrius, Fun. Orat.

Ptolemy, Geog.

Rufinus, Eccl. Hist.

Seneca the Younger, Dial.

$\longrightarrow$, Helv.

$\longrightarrow$, Marc

Socrates, Eccl. Hist.

Sozomen, Eccl. Hist.

Strabo, Geog.

Sulpicius Severus, Chron. II

$\longrightarrow$, St. Martin

Tertullian, Fug.

Theodoret, Eccl. Hist.
Heroides

Metamorphoses

Lamentations

Dialogue on the Life of John Chrysostom

Lausiac History

Description of Greece

Apology

Euthyphro

Phaedo

Every Good Man is Free

Ecclesiastical History

Natural History

Consolation to Apollonius

Consolation to His Wife

Library

Funerary Speech for John Chrysostom

Geography

Ecclesiastical History

Dialogues

Ad Helviam

To Marcia

Ecclesiastical History

Ecclesiastical History

Geography

Chronicles II

Life of Martin

On Flight in Persecution

Ecclesiastical History 



\section{Introduction}

With the arrival of a so-called Christian emperor, Constantine the Great, Christian leaders gained the long-awaited tolerance of the empire. Christianity's transition into the favored religious cult of the imperial household and Roman elite involved significant growing pains. The road to conformity was anything but smooth, as a series of controversial ecumenical councils demonstrated. In one effort to force bishops to conform, emperors used exile rather than capital punishment to compel episcopal leaders to produce a consensus on Christian practices and beliefs, a tactic that had adverse effects. As Richard Lim has noted, "By promoting the products of the conciliar process as reflecting a consensus omnium gentium, and by exiling opponents who refused to sign on, Constantine and his successors mistakenly believed they could forestall future ruptures." As we now know, this approach incited more conflict than resolution.

At the height of this troubling period between the great councils of Nicaea (325) and Constantinople (381), Christian authors would continuously characterize episcopal exile as a new martyrdom. More often than not, stories of the recent imperial persecutions were invoked to discredit the efforts of an opposing party or a particularly troublesome emperor. Accusations of colluding heretics and imperial representatives were rampant. Competing bishops relied on this powerful legacy of imperial persecution even as they argued for the recognition of the Roman Empire. The bishop's ambivalent relationship with the empire dictated the terms of his own orthodox identity and how he interpreted his experience of exile. Clerical exile then became coterminous with orthodoxy in many complicated and fragile ways. As we

1. Richard Lim, "Christian Triumph and Controversy," in Late Antiquity: A Guide to the Postclassical World (Cambridge: Harvard University Press, 1999), 200. 
will come to see, how Christians defined the experience of exile and its relationship to persecution determined where they fell on the spectrum of orthodoxy.

\section{THE DISCOURSE OF FLIGHT}

The use of episcopal exile to impose religious conformity points to a consistent dilemma for historians of late antiquity. The mid- to late fourth century saw a significant change in how Christian bishops - the new, rising Roman elite-were dealt with by a post-Constantinian Roman Empire. In this new era, the all-toofrequent outcome of doctrinal disputes among competing clerics was banishment, not martyrdom. It is quite difficult to reconstruct why or even how a particular bishop is exiled, because it is not always clear who takes the initiative to expel ecclesial leaders. ${ }^{2}$ In some cases, a group of bishops assemble a council with the intent of condemning a particular bishop for his position on a theological issue. In others, emperors are described as personally seeking out a particularly troublesome bishop. In still other cases, bishops take flight voluntarily. As a prime example, and one that will occupy us throughout this book, Athanasius of Alexandria appears to have fled into exile five times during his tenure as bishop, but it is not always clear why he was expelled or who enforced his expulsions.

If we follow the lead of the main source we have on his occasions of exileAthanasius himself-we might conclude that his initial banishment from Alexandria was simply for his own safety. When reflecting on his first departure for Gaul, Athanasius stressed that the charges made against him carried no validity. He insisted throughout his career, as did his supporters, that the emperor Constantine knew this and affirmed Athanasius's authority. Yet, even after his initial return after Constantine's death, his episcopacy continued to be challenged until the death of the emperor Valens in 378. Athanasius's many exiles ought to cause the historian to pause and ask why the departed bishop could claim that he remained the only legitimate bishop throughout his career as an exile-a claim that will continue to go uncontested in pro-Nicene orthodox memory.

It is well known that the events surrounding Athanasius's multiple trips into exile bend to different interpretations, depending on the biographer, whether ancient or contemporary. T. D. Barnes, for example, notes that some primary materials set Athanasius's defensive stance on the topic of exile in the context of his relationship with emperors, while others set it in the context of conciliar politics. ${ }^{3}$ Yet even Barnes states why it is extremely difficult even to define what constitutes a trip into exile. For instance, Athanasius's first exile (335-337) is described in painstaking detail in

2. Jennifer Barry, "Heroic Bishops: Hilary of Poitiers's Exilic Discourse," Vigiliae Christianae 70, no. 2 (2016): 155-74.

3. T. D. Barnes, Athanasius and Constantius: Theology and Politics in the Constantinian Empire (Cambridge: Harvard University Press, 1993), 46. 
three of his apologetic texts: Defense against the Arians (349), Defense before Constantius (ca. 353-357), and History of the Arians (357). All three texts were composed well after the fact and deliberately misrepresent historical events to place Athanasius in a favorable light-despite the damning evidence, much of which Athanasius himself preserved and which we will explore in detail in the next chapter.

We learn from these texts that Athanasius's claim to the Alexandrian see was disputed from a very early stage. Not only was his election called into question, but a rival bishop was also put in place by a competing Christian faction in Alexandria. In order to further undermine his authority, his enemies accused him of multiple counts of misconduct. Athanasius was accused of four charges, which he related in his Festal Letters, Defense against the Arians, and Index: he extorted the Melitian community in Alexandria, his representative Macarius destroyed church property, he was elected well below the permissible canonical age, and he bribed an imperial official. ${ }^{4}$ Athanasius was eventually also accused of murder, but the alleged victim, Arsenius, was discovered alive. ${ }^{5}$

After these charges were brought before Constantine, the emperor initially ruled in favor of Athanasius. ${ }^{6}$ Nevertheless, his accusers continued their efforts to rid themselves of their rival, and Athanasius was condemned at the Council of Tyre and again at Antioch. Athanasius appealed to Constantine once again, this time to be accused of treasonous activity. ${ }^{7} \mathrm{He}$ is said to have tampered with the grain trade to Constantinople, an act that posed a powerfully symbolic threat as well as a practical one, as Sarah Bond has recently pointed out. ${ }^{8}$ Subsequently, Constantine sent Athanasius to Trier. ${ }^{9}$

4. Athanasius, Ep. fest. 4.5; Apol. sec. 60.4; and Index 3.

5. Athanasius's biographers played up several jokes made at the expense of his accusers, who were said to have carried around a severed hand as evidence of the murder. It is unclear whose hand they had, because when Arsenius was found, all his limbs appeared to be intact. Socrates preserved this line from Athanasius at the trial: "Then addressing himself to those present, he said, 'Arsenius, as you see, is found to have two hands: let my accusers show the place whence the third was cut off'" (Socrates, Eccl. Hist. 1.24).

6. Athanasius, Apol. sec. 65.3.

7. Athanasius, Apol. sec. 86.2-12. Paul Peters also looks to Athanasius, as a well as Hilary of Poitiers, as a guide. See Peters, "Comment Saint Athanase s'enfuit de Tyr en 335," Bulletin de l'Académie Royale de Belgique, Classe des Lettres 30 (1994): 131-77. T. D. Barnes builds on his work in order to reconstruct the questionable interchange in Constantinople that eventually leads to Constantine's involvement in these ecclesiastical matters (Barnes, Athanasius and Constantius). Both Peters and Barnes cite Constantine's first dismissal of the charges laid against Athanasius after he appears before the emperor, although H. A. Drake contests the date of Constantine's interchange with Athanasius. See Drake, "Athanasius' First Exile," Greek, Roman, and Byzantine Studies 27 (1986): 193-204.

8. See discussion on the role of the baker's guild in the late Roman Empire in Sarah Bond, Taboo and Trade: Sordid Professions in the Ancient Mediterranean (Ann Arbor: University of Michigan Press, 2016), 25.

9. Athanasius, Apol. sec. 80; H. Ar. 50.2. Constantine is forced to intervene only in the History of the Arians. Presumably, it is during his time in Trier that Athanasius becomes acquainted with Constans, 
Upon Constantine's death in 337, Athanasius returned to Alexandria after an imperial edict was made by Constantinus (also referred to as Constantine II) in the West. ${ }^{10}$ But his return home was short lived. For all intents and purposes, he was still a deposed bishop by the standards of an ecclesiastical council, a point reconfirmed at the Council of Antioch in 341, under the direction of Constantius II, the emperor in the East. ${ }^{11}$ A rival bishop, Gregory of Cappadocia, was elected by the council and sent to Alexandria in 339 to reinforce this decision; he received the full support of Constantius. ${ }^{12}$ Here the historian must make a judgment call. Is Athanasius the legitimate bishop of Alexandria? Or is his replacement, Gregory of Cappadocia, the rightful inheritor of the Alexandrian episcopal seat? Athanasius ultimately contested his deposition, going so far as to state that a countercouncil was convened in Alexandria that successfully cleared him of all wrongdoing, and he even denied the validity of the synods at both Tyre and Antioch. ${ }^{13}$

As this series of events quickly reveals, Athanasius was either right or wrong to take up his post as the bishop of Alexandria, depending on the position one takes. The historian is left to answer several questions: Was his time in Trier, in fact, a period of exile? If so, what constitutes exile at this period? Several councils insist he is a criminal (Tyre and Jerusalem), and more than one emperor appears to have affirmed this position (Constantine and Constantius). Another council denied these claims (Alexandria), and another emperor (Constantine II) appeared to favor his return even when a replacement had been found and was supported by the emperor in the East. The description of this first occasion of exile is symptomatic of how difficult it is to reconstruct episcopal exile as a social phenomenon in antiquity. Barnes alludes to this difficulty when he says, "The exile of Athanasius in 335 was not the normal exile imposed by an emperor on a bishop who had been condemned and deposed by a church council." ${ }^{14}$ Curiously, Barnes defines "normal exile" by appealing to another controversial bishop, Eusebius of Caesarea, who wrote: "He [Constantine] likewise added the sanction of his authority to the decisions of bishops passed at their synods, and forbade the provincial governors

whom he credits for securing his reprieve from his second trip into exile (Athanasius, Apol. Const. 4.2, edition: Hans-Georg Opitz [Lieferungen 1-7] and H. C. Brennecke et al. Lieferung 8: [200o] Apologia ad Constantium, pp. 279-304; translation in consultation with the Greek and NPNF2 4. Apol. sec. 3-19). T. D. Barnes cites Hilary of Poitiers (and Sulpicius Severus, who follows Hilary's lead), in whose works we find direct imperial involvement in Athanasius's expulsion. See Barnes, "Hilary of Poitiers on His Exile," Vigiliae Christianae 46, no. 2 (1992): 134.

10. Athanasius, Apol. sec. 87.4; H. Ar. 8.2.

11. The Council of Antioch reaffirms both Tyre and Jerusalem, condemning Athanasius's return to Alexandria. He is also faulted for a self-initiated return. We will return to this ambivalent legacy in chapter 4 .

12. Athanasius, Apol. sec. 29; Ep. Encyl. 2.1.

13. Athanasius, Apol. sec. 3-19.

14. Barnes, Athanasius and Constantius, 24. 
to annul any of their decrees: for he rated the priests of God at a higher value than any judge whatever." ${ }^{15}$ Yet Eusebius's interpretation presupposes that Constantine could easily identify which council to favor and determine which one was orthodox, a point with which Athanasius and his biographers ardently disagreed. Exile as a social phenomenon is extremely difficult to reconstruct. And yet it remains one of the most pressing topics for historians of antiquity.

\section{EXPLORATIONS OF EXILE}

Ernst Ludwig Grasmück's work is the foundation for most scholarship on exile in antiquity ${ }^{16}$ His most significant contribution is the seemingly simple observation that exile had a specific political function in antiquity: to offer an alternative to the death penalty. His study includes a close examination of the interplay between power and law in Roman, Greek, and Jewish legal practices. He concludes that exile, no matter how one defines it, is not only a social reality but also an important mediator of social politics. The conventional approach deemed it sufficient to look at the legal causes of exile, but Grasmück emphasizes that this is not enough. ${ }^{17}$ In order to explore how exile actually functioned in Roman politics, historians must also explore the political and sociocultural conditions that gave rise to instances of exile.

Gordon Kelly also attempted to identify how exile functioned as a social reality in Rome in the period between the Second Punic War and the death of Julius Caesar (220-44 BCE). In order to do so, he defined exilium as a voluntary act taken by a senatorial or an equestrian male to avoid legal proceedings. ${ }^{18}$ After the

15. Eusebius of Caesarea, Life of Constantine 4.27.2.

16. Ernst Ludwig Grasmück, Exilium: Untersuchungen zur Verbannung in der Antike (Paderborn: Schoningh, 1978).

17. Grasmück builds on the work of scholars such as Ferdinand Walter, Geschichte des Römischen Rechts bis auf Justinian (Bonn, Germany: Weber, 1861), and Theodore Mommsen, Römisches Strafrecht (Graz, Germany: Akademische Druck- und Verlagsantstalt, 1955). Specifically, Grasmück sought to correct the prevailing notion that saw exile as voluntary and self-imposed. This elite view of exile is also critiqued by Peter Garnsey, Social Status and Legal Privilege in the Roman Empire (Oxford: Clarendon, 1970), 275.

18. Gordon Kelly, A History of Exile in the Roman Republic (Cambridge: Cambridge University Press, 2006) argues that, prior to the period between the Second Punic War and the death of Julius Caesar (220-44 BCE), the phenomenon of exilium is not mentioned aside from a suspect account of the banishment of Camillus in 392 BCE. See Kelly, A History of Exile in the Roman Republic (Cambridge: Cambridge University Press, 2006). Frank Stini has also added to and expanded Kelly's assessment in his expansive work, Plenum exiliis mare: Untersuchungen zum Exil in der römischen Kaiserzeit (Stuttgart, Germany: Franz Steiner Verlag, 2011). Stini provides a great deal of prosopographical details concerning the sheer numbers of exiles during this same period of time. There is also an extensive, and invaluable, index at the end of his book. His overall focus moves beyond this material alone and moves to a more ambitious project: to identify the motivation behind exile from an imperial and legal standpoint. This shift in focus helped to highlight the significant role individual imperial personalities would 
exile departs, the decree aquae et ignis interdictio, "interdiction of fire and water," is made by the concilium plebis, the plebeian assembly, in order to ensure his permanent banishment. ${ }^{19}$ Kelly concludes that the Roman Republic successfully used exilium as a safety valve or a gentleman's agreement to stave off political unrest.

Peter Garnsey and Caroline Humfress note the similar role exile played in Roman politics well into the Principate..$^{20}$ Even though the definitions of Roman citizenship fluctuated over the course of the next few centuries, the penal act of exile was still reserved for the privileged social classes. Garnsey and Humfress trace how the extension of Roman citizenship to all freeborn men by Caracalla in 212 set in place new social structures that redefined the categories of "citizen" and "alien." Citizenship was a prerequisite for any participation in the senatorial and equestrian orders. It also inferred upon these new Romans a juridical status that gave rise to legal recourse previously withheld. The extension of citizenship to all freeborn individuals allowed many who had previously been excluded to enter new brackets of social status, a historical shift that eventually worked to the advantage of ecclesiastical offices in a post-Constantinian context.

As more elite Romans adopted Christian practices after Constantine's reign, both the empire and Christians had to contend with competing ideologies of citizenship, because the identity of citizen-insider remained a complex one in Christian memory. After Constantine's rise to power and growing toleration of Christian practices, professed Jesus followers began to redefine Roman citizenship. Its positioning as an identity opposed to the alien created complex and contradictory identities for many late ancient Christian authors, so much so that Caracalla's edict, which granted citizenship to all free inhabitants of the Roman Empire, was easily adopted into the Theodosian Code in 436 . And by the time Justinian sought to revise the Roman law in the sixth century, Roman citizenship and pro-Nicene Christian identity could be seen as one and the same. ${ }^{21}$

Such a vision of the Christianization of Roman identity admittedly has its limitations. After Constantine demanded that Christians reach a consensus over

play in the displacement of Roman citizens. Exile is seen as a less extreme form of punishment and a substitute for capital punishment.

19. Richard Bauman also assesses the legal implementation of the interdiction of fire and water in his Crime and Punishment in Ancient Rome (New York: Routledge, 1996), 16-20. Exile is not his primary interest, but he discusses it as one of a variety of Roman legal practices present in the literature. Bauman notes that exile could be both voluntary and compulsory and insists that, although it was initially considered merely a custom, it was eventually brought into the legal system.

20. Peter Garnsey and Caroline Humfress, The Evolution of the Late Antique World (Cambridge: Orchard Academic, 2001), 143-52. This introductory text seeks to correct previous misrepresentations of the late Roman Empire espoused by historians such as Edward Gibbon. Rather than viewing the third through fifth centuries as a stagnant period, the authors insist that this period was dynamic and full of creative transformation.

21. Ibid., 142. 
faith and practice, political unrest continued, and all would not rest comfortably with this newfound citizenship. The theological controversies that dominated the fourth and fifth centuries reveal just how contested the citizen-insider identity truly was for the vast majority of Christians across the empire. As the term "Christian-insider" began to be associated with a pro-Nicene theological stance, tensions were raised. Christians continued (and still continue) to wrestle over how this identity should be defined and remembered. New threats to civic concord, such as interreligious conflicts, resulted in familiar responses from the empire. Although the pool of candidates for exile widened considerably by the fourth century, exile essentially served the same purpose: to create and enforce stability. Yet decisions about what constitutes an exile and who enforces those decisions remains a complicated issue, due in no small part to the terms associated with exile as a social phenomenon.

One of the principal difficulties historians then face is that ancient authors had a much more ambiguous interpretation of exile than modern interpreters. As Jan Felix Gaertner succinctly puts it, "ancient authors do not distinguish between exile and other forms of displacement." ${ }^{22}$ The fluidity Gaertner emphasizes here is reflected in the variety of terms that are used to describe exile, such as the Greek ekstasis, "displacement," phygē, "flight," ekōsma, "banishment," or Latin fuga, "flight," relegatio, "relegation," peregrinatio, "pilgrimage," and exilium, "exile." Classicists have noted this variation in the work of well-known exiles. Ovid ( $43 \mathrm{BCE}-17 \mathrm{CE}$ ), exiled by Augustus in $8 \mathrm{CE}$, employed exilium, fuga, and relegatio interchangeably in his exilic works. He played with the vocabulary in order to describe his experience as a type of death, both physical and social: "When I lost my native land, then must you think that I perished; that was my earlier and harder death., ${ }^{23}$ Seneca the Younger (ca. 1 BCE-65 CE), exiled by the emperor Claudius, denied that exile even exists: "Inside the world there can be found no place of exile [exilium]; for nothing that is inside the world is foreign to mankind." ${ }^{24}$ And the exile Dio Chrysostom (ca. 40-120 CE) envisioned his status under the reign of Domitian as a privileged, even enviable state: "If I narrate the course of my exile [phygein], men will say, not that I am lamenting, but far rather that I am boasting." 25

Like their classical counterparts, early Christian authors also manipulated terms to describe their exile in a variety of ways. Common terms associated with the concept of exile are the verbs "to hide" (kryptein) or, as we saw in the prologue

22. Jan Felix Gaertner, introduction to Writing Exile: The Discourse of Displacement in Greco-Roman Antiquity and Beyond (Leiden: Brill, 2007), 3.

23. Ovid, $\operatorname{Tr}$. 3.3.53-54. See also $\operatorname{Tr}$. 1.4.27-28: "Save yourself my weary life from cruel death, if only it were possible for one already dead not to die." Edition and translation: LCL 151, xl-xli.

24. Seneca the Younger, Helv. 8.5. Edition and translation: LCL 254.

25. Dio Chrysostom, Orat. 45.1. 
with Cyprian, "to flee" (phygein). Flight ties exile to other past experiences of compulsory retreat or preemptive acts taken to avoid violence and will remain central to our examination. For example, Athanasius explicitly states that he chose to hide for a time in order to avoid death: "It would neither have been becoming in me to surrender, and give myself up that my blood might be shed. ... It was therefore better for me to hide [krybēnai] myself." ${ }^{\prime 26}$ Athanasius's contemporary, Hilary of Poitiers, also justifies his occasion of exile by comparing Constantius II to one of the most infamous emperors in Christian history: "it is lawful for me to flee [fugere] under a Nero." ${ }^{27}$ He scathingly concludes that flight is certainly permissible if an irascible despot sits upon the throne.

Another common description of Christian exile includes exile as an ascetic discipline. As Daniel Caner convincingly argued, ascetics reinterpreted the practice of wandering as a self-exile (xeniteia). ${ }^{28}$ Wandering monks saw themselves as the inheritors of a long-standing apostolic tradition and, by the fourth and fifth centuries, considered it a legitimate form of ascetic practice. This practice was by no means without its critics. Evagrius of Pontus (345-399) affirmed the state of alienation but put extraneous constraints upon and issued dire warnings for those who dared to wander beyond their desert cells. ${ }^{29}$ Macarius the Great (ca. 300-391) also cautioned against such activity, ${ }^{30}$ along with other critics, like Augustine (353-430), Jerome (ca. 340-420), and John Cassian (ca. 360-435), who all found it fodder for polemical debate. ${ }^{31}$

The activity of wandering nevertheless remained a prevalent topic for discussion among the ascetic fathers and mothers of the desert, ${ }^{32}$ so much so that exile as a type of ascetic wandering quickly became a favored topic in later western exilic

26. Athanasius, Apol. Const. 34-35.

27. Contra Const. 11. For a more detailed examination of Hilary's treatment of these texts in relation to his exile, see Richard Flower, Emperors and Bishops in Late Roman Invective (Cambridge: Cambridge University Press, 2015), 81-88, and Barry, "Heroic Bishops."

28. Daniel Caner expands on this observation by developing the topic of wandering and begging monks in late antiquity in his Wandering, Begging Monks: Spiritual Authority in Late Antiquity (Berkeley: University of California Press, 2002).

29. For a detailed discussion on Evagrius's interpretation and use of the concept of xeniteia, see Robyn Darling Young, "Xeniteia According to Evagrius of Pontus," in Ascetic Culture: Essays in Honor of Philip Rousseau, ed. Blake Leyerle and Robin Darling Young, 229-52 (Notre Dame: University of Notre Dame Press, 2013).

30. Evagrius, Ant. 1.37; and G. Macarius, Aeg. 2. Evagrius in particular combines the theme of the xenos with the physical act of wandering.

31. The topic of wandering monks and the ills of this practice are discussed in Augustine, Op. mon.; Jerome, Epist. 22; and John Cassian, Conlat.

32. Expanding further east, we find similar itinerant monastics in Syriac Christianity as well. Caner specifically notes the similarities of the Messalian community described in the Book of Steps. Alexander the Sleepless is used as a case study to support his point. See Caner, Wandering, Begging Monks, 126-57. 
discourses, when understood as a type of pilgrimage..$^{33}$ In this vein, Augustine even used peregrinatio (a sojourn or a pilgrimage) as a synonym for exile (exilium, fuga, etc.) in order to describe the state of the civitas dei on earth. ${ }^{34}$ Isidore of Seville (560-636) consistently defined the peregrinus as someone who is outside of his own country, while Boethius (ca. 480-525) integrated the concept of peregrinatio with exilic consolatory themes from Ovid's poetry in order to capture the condition of the everyman as a homo viator, "pilgrim man." And Adomnan of Iona (ca. 627-704) refers to Columba's ministry to Iona as peregrinatio in his Life of St. Columba.

What seems to be most important for the scope of this book is not how these terms are translated in what we might consider a technical fashion but how they are used by Christian authors as a way to represent a larger social reality. It is the flexibility of these terms that reveals how the discourse of exile adapts to political and theological Christian arguments that arise in this tumultuous period.

\section{EPISCOPAL EXILE}

The transition from a faith targeted by the empire to a faith that wielded political force was by no means a smooth one. This shift becomes all the more evident when we look at the different ways exiled bishops used exile as a means of shaping identity. Exile played a significant role in how Christian leaders, as the new Roman elite, interpreted the Christian past in their present moment. According to Eric Fournier, the rise of this new Roman elite redefined the quality and the meaning of exile in late antiquity. The new status of the bishop, in particular, forced imperial authorities to rethink how bishops who broke public laws ought to be punished. Fournier points to the inconsistent use of exile by the empire as a way to quell political unrest and explores how exile helped to shape an identity of persecution particularly in the Latin West. ${ }^{35}$ And, like Grasmück, he contends that exile

33. At the 2002 International Medieval Congress at the University of Leeds, scholars examined the different forms exile took during the Middle Ages from ca. 900 to ca. 1300 in western Europe, and the proceedings were published in Laura Napran and Elizabeth van Houts, eds., Exile in the Middle Ages (Turnhout, Belgium: International Medieval Research, 2004). The second half of the volume focuses on exile in an ecclesiastical context as it is linked to new interpretations of Christian identity. And while this book will not focus on the western evolution of the exile to pilgrim, it remains a pertinent topic that will arise in our focus on the Eastern Roman Empire.

34. Augustine, Civ. 11.28 and 14.9. Manuela Brito-Martins links the verb peregrinor to the Greek verb apodèmeō, a term used by Plato, Apol., $61 \mathrm{e} 1$ and $67 \mathrm{cr}$. She also points to the verb ekpēdaō, from which is derived exsiliare, lactus exsiliendi, "flight." See Brito-Martins, "The Concept of Peregrinatio in Saint Augustine and Its Influences," in Exile in the Middle Ages, ed. Laura Napran and Elizabeth van Houts, 83-94 (Turnhout: International Medieval Research, 2004), 84n9.

35. Eric Fournier, "Exiled Bishops in the Christian Empire: Victims of Imperial Violence?" in Violence in Late Antiquity. Perceptions and Practices, ed. H. A. Drake, 157-66 (Burlington, VT: Ashgate, 2006); "Victor of Vita and the Vandal 'Persecution': Interpreting Exile in Late Antiquity" (PhD diss., 
functioned as a mechanism to alleviate social pressures but that the process was neither consistent nor well defined.

Daniel Washburn has also provided a detailed examination of Roman law and the practice of exile. ${ }^{36}$ He showed how exile functioned as a rehabilitative and restorative legal process negotiated between the exiler and the exiled within the Roman Empire from the Principate to the early fifth century. This process was intended to highlight the political superiority of the ruling authority. Christian authors thus relied upon a variety of literary depictions of banishment to negotiate their circumstances. Washburn concludes that the motivation for exile was to "transform the heterodox into the orthodox." ${ }^{37}$ This last statement reveals a great deal about the powerful nature of exilic discourse and how early Christians used it to identify orthodoxy and its links to persecution.

Like Fournier, Julia Hillner has also examined the rhetoric of persecution and how it shaped Christian imagination and the experience of exile, drawing particular attention to the martyrization of exile and the presence of a productive literary link between exile and Christian confinement. ${ }^{38}$ Hillner also edited, along with Jörg Ulrich, and Jakob Engberg, a volume that lays out the many complexities involved in efforts to trace episcopal exile in late antiquity. ${ }^{39}$ This volume touches

University of California, Santa Barbara, 2008); and, "Constantine and Episcopal Banishment: Continuity and Change in the Settlement of Christian Disputes," in Hillner, Ulrich, and Engberg, Late Antique Clerics in Exile Late Antique Clerics in Exile, 47-66. For another text that focuses on the Latin West and deploys the use of prosopographical data, see Jonathan Conant, Staying Roman: Conquest and Identity in Africa and the Mediterranean, 439-700 (Cambridge: Cambridge University Press, 2012). In his chapter, "Flight and Communications," Conant mines his sources for data that traces social movements between East and West at a later period than explored here. He then uses this data to trace particular exiled figures in the West. See Conant, Staying Roman, 67-129.

36. Daniel Washburn, Banishment in the Later Roman Empire, 284-476 C.E. (New York: Routledge, 2013). This revised dissertation ("Banishment in the Later Roman Empire: The Rhetoric and Realities of a Disciplinary Institution" (PhD diss., Stanford University, 2007]) notes the complicated overlay between what he terms sacred (Christian) and secular (Roman) politics. He attempts to draw parallels between the two institutions but falls into an argument that presupposes that an orthodoxy already realized. For example, he states, "After all, a bishop could have maintained perfect orthodoxy but still commit a banishment-worthy violation of Roman civil law" (Washburn, Banishment, 42). He also emphasizes that the exile of episcopal leaders could not have taken place without the direct involvement of secular resources.

37. Washburn, Banishment, 47.

38. Julia Hillner also invokes Washburn's concept of the Christian identity crisis. See Hillner, Prison, Punishment, and Penance (Cambridge: Cambridge University Press, 2015), 253n44. I also make note of this development in Barry, "Heroic Bishops."

39. Julia Hillner, Jörg Ulrich, and Jakob Engberg, eds., Late Antique Clerics in Exile (New York: Peter Lang, 2016). This volume is the product of a prearranged workshop held at the Seventeenth International Conference on Patristic Studies in August 2015 and provides ample data that support the prevalence of forced movement of clerics across the late Roman landscape. In her introduction to that volume, Hillner assesses the various methods used by late ancient historians and theologians to reconstruct this trend. See Hillner, introduction to Hillner, Ulrich, and Engberg, Late Antique Clerics 
on the complicated social networks at play in any given assessment of Christian exile. Clerical exile, in particular, was "a community event, in the sense that it was a real or metaphorical mechanism of inclusion and exclusion, which both created relationships and drew the boundaries of late antique Christian society." ${ }^{\circ}$ The experience of exile was hardly a solitary phenomenon, and its study is equally reliant on interdisciplinary approaches and methods.

The book builds on those interventions and conversations and turns to consider more narrowly how episcopal exiles created new pressures and possibilities for the discourse of orthodoxy and heresy. Here it will be argued that the discourse of exile served as a new rhetorical and discursive mode in heresiological discourse-and a notably fluid and flexible one at that, as Christians looked to earlier literary sources to help them to understand and articulate their own experiences.

\section{MODELS OF EXILE}

To reiterate, exile in antiquity was not just a concrete sociopolitical phenomenon; it also functioned as a discursive performance or an act of rhetorical self-representation. The reality of exile, in all its diverse forms, helped to shape ancient imaginative processes. Sarah Cohen demonstrates how the theme of exile was a powerful discursive resource for Cicero (106-43 BCE), who made full use of exilic paradoxes to comment on the res publica and to define his own position within the aristocracy in 47 BCE. ${ }^{41}$ After his return from Greece, Cicero composed his Post reditum ad populum, in which he compared his exile to the departure of the res publica from Rome. Building on his discourse on the legitimacy of the state found in On the Commonwealth, Cicero concluded that since there was not a state to be exiled from, he was never actually exiled. In a contemporaneous work, Stoic Paradoxes, he used the same logic to shame Clodius, his chief rival and the principal instigator behind his departure from Rome. He made use of irony to turn the logic of exile on its head: "Clodius is presented as doubly a fool: not only did he mistakenly believe that he had exiled Cicero, but he himself was the one who made

in Exile. Sections from chapter 4 of this book, below, appear in my own contribution to that volume; see Jennifer Barry, "Receptions of Exile: Athanasius of Alexandria's Legacy," in Hillner, Ulrich, and Engberg, Late Antique Clerics in Exile. An additional invaluable resource organized by many of the participants, including the principal investigator, Julia Hillner, is the digital humanities project titled The Migration of Faith: Clerical Exile in Late Antiquity, www.dhi.ac.uk/sites/clericalexile. Among many of its vast array of resources, the site includes an extensive database of exiled clerics and various visualization options that are free and open to the public.

40. Hillner, introduction to Hillner, Ulrich, and Engberg, Late Antique Clerics in Exile, 24.

41. Sarah Cohen, "Cicero's Roman Exile," in Writing Exile: The Discourse of Displacement in GrecoRoman Antiquity and Beyond, ed. Jan Felix Gaertner, 109-28 (Leiden: Brill, 2007). 
Cicero's exile impossible by destroying the legitimate state." ${ }^{42}$ Cicero could not be exiled from that which did not exist.

Cohen goes on to compare the exilic metaphor found in Stoic Paradoxes with its use in a series of letters written by Cicero around the same time. These letters are concerned primarily with the recall of Marcus Claudius Marcellus, Caesar's staunchest political opponent. Marcellus's refusal to return after Caesar's rise to power prompted Cicero to state that the legitimate res publica remained in exile alongside Marcellus. To justify his own return, however, Cicero argued that he was obliged to work for the return of res publica to Rome itself, which included trying to persuade Marcellus and a host of other former followers of Pompey, Caesar's primary opponent in the Civil War, to return. Cicero concluded that one's exile is not dependent upon a physical location but derives from one's distance from the true res publica. Instead of attempting to reconstruct a historical reality (which she neither defends nor contests), Cohen focuses on Cicero's use of the theme of exile to create a rhetoric of political legitimacy, a theme we will see replicated by Christian authors.

Standard exilic motifs were just as common in the composition of exilic poetry. Gaertner looks at the use of conventional themes in two works composed by Ovid, Lamentations and Letters from Pontus. While previous scholars concluded that Ovid's exilic poetry is somehow remarkably different due to his experience of exile, Gaertner argues that certain philological continuities easily refute such claims. ${ }^{43}$ He supports this argument by exploring the literary conventions used throughout the two cited works. For example, the themes of suicide, evident in Cicero's reflections, and exile as a social death are prevalent throughout these two works. The consolatory tradition proves to be particularly useful for Ovid, who "was well acquainted with the tradition of consolatory treatises on exile, and this very tradition offers precedents not only for Ovid's stereotypical descriptions of his surroundings in Tomis, but also for the repeated comparisons between the poet's plight and the wanderings of mythical characters such as Odysseus and Aeneas and the exile of historical persons such as Themistocles or Aristides." 44 Ovid, Gaertner stresses, is hardly novel. ${ }^{45}$

The marked similarities connect Ovid's exilic poetry to his earlier works, such as Amours, Art of Love, Remedy of Love, Metamorphoses, and The Book of Days. Ultimately, Gaertner wants to refute the charge that Ovid's work declined in its

42. Ibid., 116. The mistaken fool is a theme that Athanasius and other Christian exiles will use to lambast their persecutors.

43. Jan Felix Gaertner, "Ovid and the 'Poetics of Exile': How Exilic Is Ovid's Exile Poetry," in Gaertner, Writing Exile, 155-72.

44. Ibid., 158.

45. Later authors such as John Chrysostom will also deploy similar themes, which I will explore in greater detail in chapter 3 . 
technical sophistication due to the hardships of his exile. Here he corrects a trend in scholarship that attempts to psychoanalyze the poet by stating that such claims are dubious and easily undermined with careful philological study. ${ }^{46}$ Although Ovid does make use of prosaic and colloquial phrases, his metrical features actually reveal a link to Horace's Epistles. Gaertner insists that there is no credible evidence pointing to an intellectual decline; tracing the literary heritage makes clear that Ovid is creatively reproducing a standard form of exilic poetics. As we will see in later chapters, similar accusations are made against John Chrysostom as he writes to his supporters while in exile. The epistolary themes in both collections of letters point to a shared literary discourse and suggest that historians ought to temper any claims of decline based on overly zealous psychoanalysis of our writers.

Familiar exilic themes were also used by authors to challenge the political norm, which will be of chief importance for this study. For example, Tim Whitmarsh has examined how Dio Chrysostom actively took on the Roman ideologies of citizenship and imperial power through exilic tropes. ${ }^{47}$ In On Exile, Dio clearly relied on Socrates's moment of enlightenment in the Apology as a philosophical model. During his exile under Domitian, Dio recalled a clandestine meeting with an oracle who encouraged him to embrace his identity as a perpetual exile. Dio self-consciously employs Socratic irony as a way to position himself firmly within the philosophical tradition. His time in exile served as a defining moment in his philosophical journey, which continued even after he was permitted to return to Rome. As the ambassador to the emperor rather than as an enemy, Dio was forced to mediate a difficult position: although he had recovered his status as a legitimate citizen of the empire, he insisted on retaining his outsider status. Whitmarsh concludes that this identity helps Dio express his ambivalence as both a Greek ethical idealist and a Roman political agent.

46. Gaertner, "Ovid," 155. The most influential example is found in E. Doblhofer, Exil und Emigration: Zum Erlebnis der Heimatferne in der römischen Literatur (Darmstadt, Wissenschaftliche Buchgesellschaft, 1987). Doblhofer argues that there is a traceable universal psychological condition of exile that emerges out of Roman exilic literature. He highlights what he sees as an isomorphism of human experience, a condition that develops out of the ancient experience and translates across the centuries. He supports this argument by describing exile as a sickness, or Exilkrankheit-a psychological sickness inherent in all exilic experiences and stresses that the literary expression of Heimatfern, "homesickness," is the primary connecting feature within the larger body of exilic literature producing an identifiable nosography. Building on Doblhofer's observations, Jo-Marie Claassen examines more closely the development of the psychological phenomenon of Exilkrankheit in antiquity in her Displaced Persons: The Literature of Exile from Cicero to Boethius (Madison: University of Wisconsin Press, 1999). Claassen agrees that this condition is clearly evident in the literature of exile-or those texts that express the emotional aspects of the experience of exile. For her more developed argument on the condition of exile, see Claassen, Ovid Revisited: The Poet in Exile (London: Duckworth, 2008).

47. Timothy Whitmarsh, "'Greece in the World': Exile and Identity in the Second Sophistic," in Being Greek under Rome: Cultural Identity, the Second Sophistic and the Development of Empire, ed. Simon Goldhill, 269-305 (Cambridge: Cambridge University Press, 2007). 
Dio invoked the literary model of Odysseus to support this dual role: "I reflected that Odysseus after all his wanderings did not hesitate to roam once more. . . Should I not follow his example if god so summons? So after exhorting myself in this way to neither fear nor be ashamed of my action, and putting on humble attire and chastening myself, I proceeded to roam everywhere." ${ }^{48} \mathrm{He}$ relied on this countercultural hero to strike a balance. Like Odysseus, exile "serves as a self-constructed aetiology for Dio's reputation as a brave and outspoken purveyor of Greek ideals in the face of Roman authority." ${ }^{49}$ Dio Chrysostom then advises the Romans:

I would tell them that they needed a better and more carefully planned education, if they were ever to be happy in truth and reality and not merely in the opinion of the majority, as was now the case; that if anyone should win them to this view and take them in charge and teach them that not a single one of those things is a good to which they devoted themselves and which they strove, with all their zeal to acquire, in the belief that, the more they acquired, the better and happier their life would be; but that if they wholeheartedly practiced temperance, manliness, and justice, and took them into their souls, securing from somewhere teachers who taught these things and all the other things too, not caring whether the men were Greeks or Romans. . . "For only then," I continued, "will your city be great and strong and truly imperial, since at present its greatness arouses distrust and is not very secure." (Exil. 13.31-34) $)^{50}$

Such classical examples further emphasize that the status of citizen insider/outsider and its relationship to the condition of exile is a powerful discourse that bends to the rhetorical needs of the author. As will be argued throughout this book, Christian leaders also had to strike a balance as they attempted to straddle new roles as agents of the empire and mediators of Christian orthodoxy. This was an ongoing battle for Christian authors, who had to compete with a past that continuously threatened to undermine any or all allegiances to a once hostile empire. The identities of Christian and Roman citizens frequently came into conflict, as we will come to see. Once martyrologies became popular, this identity became all the more fraught and infused with cultural meaning.

The estranged or marginalized figure is by no means a new critical angle from which to examine ancient Christian texts. Unfortunately, the position of alterity in early Christian texts has more often than not been conflated with a singular vision of Christian identity: to be a Christian is to be an alien. Benjamin Dunning complicates this vision by arguing that the figure of the xenos, "alien," in the pre-Constantinian period is much more fluid than it is commonly perceived to be. ${ }^{51}$ Unlike other scholars before him, Dunning shows how the identity of the

48. Dio Chrysostom, Orat. 13.10-11.

49. Whitmarsh, "Greece in the World," 290.

50. Edition and translation: LCL 339.

51. To make this point, Benjamin Dunning closely examines the cultural continuum this identity spans in early Christianity by paying particular attention to five different texts: 1 Peter; Hebrews; Epistle 
alien contains a host of generative possibilities that produce competing, even contradictory, Christian identities. Rather than reinforce one vision of Christian alterity, early Christian texts reveal multiple sites of contestation. In the Epistle to Diognetus, for instance, the status of the alien is valorized as a marginal identity while simultaneously understood to reaffirm traditional cultural norms. Dunning remarks, "Having become resident aliens by virtue of conforming to Roman norms even better than the Romans do, Christians in fact prove to be of absolutely vital importance for the social order." ${ }_{52}$ By way of contrast, the Apocryphon of James rejects the valorization of alien identity: "The text invokes the category of the stranger [exile] not to exploit its valorized possibilities but rather to conjure up the specter of the 'un-citizen' with all its potentially negative valences." 53 Thus the trope of the alien in the larger cultural milieu takes on new interpretive meanings by blurring the distinction between civic and what Dunning deems "ethnoracial" categories of status and identity within Graeco-Roman literature. Its overlap with the trope of exile demonstrates how the Christian alien stands as the other to the most prominent insider identity: that of the citizen. This parasitic relationship highlights the instability of Roman boundaries, most especially those borders that constitute Roman identity in particular places in the empire.

In the first two centuries of the common era, Greek and Roman authors often appealed to exilic themes to construct a powerful identity to counter that of citizen-insider. For instance, both Plutarch and Philo easily adopted the language of exile in order to describe the state of the human soul as it sojourns on earth. ${ }^{54}$ Exile from the polis enacts a certain social death: it is easily and immediately

to Diognetus; Shepherd of Hermas, Similitude 1; and Apocryphon of James. Each of these texts contains a different answer to Dunning's driving question: why did the first Christians speak about themselves as resident aliens? In addition to the term xenos, Dunning also looks at paroikos, parepidēmos, and allotrios. See Dunning, Aliens and Sojourners: Self as Other in Ancient Christianity (Philadelphia: University of Pennsylvania Press, 2009).

52. Ibid., 76 .

53. Ibid., 99. The Apocryphon of John, notably, is placed among a collection of so-called gnostic texts. Dunning successfully incorporates this text back into an expansive collection of diverse Christian texts rather than relegating it to the margins of this period as the majority of biblical scholarship has tended to do; see in particular his explanation and justification of its use (ibid., 7-8, 91-102) and his brief examination of the text itself, as well as justification for its inclusion in the survey (ibid., 92-94).

54. This body of literature created a flexible identity that Greek and Roman writers invoked to articulate the function of exile in a given text. Dunning also includes the reflections of Jews in the Graeco-Roman world: "The stories of exile and diaspora to be found in the biblical texts provided powerful narrative resources for Jews in the project of maintaining Jewish identity in complex multicultural scenarios" (ibid., 74). James M. Scott highlights in this earlier work the alienation of Jewish diaspora from conversations on exile or displacement of Christian authors within biblical studies, not to mention a neglect of the overlap with Graeco-Roman texts during the Second Temple period. See Scott, "Exile and the Self-Understanding of Diaspora Jews in the Greco-Roman Period," in Exile: Old Testament, Jewish, and Christian Conceptions, ed. James M. Scott, 173-218 (Leiden: Brill, 1997). 
perceived as either a lamentable state or a praiseworthy occurrence. When early Christians adopted the topos of the alien "as a resource for articulating the shape and meaning of their own identities, they did so as participants in an already complex conversation." ${ }^{55}$ This powerful theme of citizen-outsider-more specifically, of exile-extended well into the fourth and fifth centuries, resuscitated by Christian authors of late antiquity who looked to the past in order to interpret their present.

A rich literary corpus on the state and condition of exile thus yields a flexible and powerful trope and identity. The formation of exilic identities in late antiquity continuously draws from and mimics discursive formulas found in earlier Greek and Roman exilic literature. Late ancient Christian authors looked to their literary predecessors as a guide for talking about and defining exile. Christian authors also appealed to popular narratives to reimagine themselves as famous classical exiles such as Cadmus, Heracles, Jason, and Patroclus. Odysseus is a particular favorite among late antique biographers, as Patricia Cox Miller has observed. ${ }^{56}$

In addition to these classical characters, Christian authors alluded to biblical exemplars in order to fashion flexible exilic identities. Each author examined in this study appealed to specific biblical figures in flight: Athanasius likened his experiences to those of Jacob, Moses, Elijah, and all those other men who flee into the desert to avoid persecution. John Chrysostom, in order to stress the fortitude that comes from facing hardship, contrasted those Jews resting comfortably in their homeland after their return from Babylon with those noble children in the book of Daniel who win their glory as exiles. What stands out in these interpretive strategies is the connection between alienation and objective truth. And like Paul, the exile as the outsider brings with him Christian truth - that is, until its objectivity is undermined by its very own alienation..$^{57}$

55. Dunning, Aliens and Sojourners, 44.

56. Patricia Cox Miller, Biography in Late Antiquity: A Quest for the Holy Man (Berkeley: University of California Press, 1983), 121. The motif of Odysseus is repeated in both early and late ancient Christian literature as well as non-Christian literature. Miller also references Porphyry's use of the Odysseus image as "an exploration of the true self" (ibid., 122).

57. Timothy Luckritz Marquis has also convincingly shown how Paul deployed exilic identities in several of his works. His identity as a wanderer was tied to exilic themes. These themes, such as the wandering practitioner and the cosmopolitan philosopher, were particularly important to later Christian writers who would look to Paul as an example of an orthodox Christian in flight. This positioning was not merely a reception of exilic rhetorical motifs, but, as Luckritz Marquis convincingly claims, Paul creatively used classical motifs to fashion himself as a wandering preacher and a despised foreigner to emphasize his message of truth. See Timothy Luckritz Marquis, Transient Apostle: Paul, Travel, and the Rhetoric of Empire (New Haven, CT: Yale University Press, 2013). Luckritz Marquis focuses principally on Romans and 2 Corinthians to zero in on Paul's use of exilic themes. He creatively examines how travel was paramount to Paul's message, as the apostle styled himself as an itinerant preacher. His appearance as an outsider bringing with him teachings of a foreign cult had to be explained and justified to those who were suspicious of his intentions and message. 
Literary study of the theme of exile opens up new ways of reading late ancient texts and will be the principal approach of this book. We will trace the development of the various discursive techniques used by bishops and their biographers to interpret the experience of exile. By paying attention to the way exile functions in different texts, we begin to see how exile is employed by heresiological discourse. And as we will come to see, the theological debates that ensued in the aftermath of Nicaea shaped the Christian imagination. Exile then served as a flexible discourse that allowed authors to think through the boundaries and limits of orthodoxy.

\section{HERESIOLOGY AND EXILE}

By examining the discourse of exile in addition to exile as a social phenomenon, we are able to revisit some important historiographical interventions made by scholars in the last two decades as they relate to orthodoxy and heresy. ${ }^{58}$ As Teresa Shaw summarizes, "recent studies have challenged scholars to 'rethink' previous understandings of 'heretical' individuals and groups, understandings that in many ways relied on ancient genealogies and labels developed in the agonistic context of theological dispute and its aftermath." 59 So, too, when the language of orthodoxy and heresy is invoked in the context of exilic discourse, the historian must remember that episcopal exiles during the fourth and fifth centuries were thoroughly embroiled in theological disputes. ${ }^{60}$ While interreligious disputes were by

58. A resurging interest during the 1990 s in the concept of orthodoxy and its twin, heresy, in the history of Christianity culminated in two overlapping schools of thought. In 1996 the Journal of Early Christian Studies (vol. 4, no. 4, winter 1996) published a collection of essays on heresy in late antiquity presented at the University of British Columbia's Twenty-Fourth Medieval Workshop (1994). Then, in 1998, a group of scholars gathered at the École française de Rome and also published a collection of essays that includes the Middle Ages and modernity (Susanna Elm, Eric Rebillard, and Antonella Romano, eds., Orthodoxie, Christianisme, Histoire: Orthodoxy, Christianity, History, CÉFR 27o (Rome: École francaise de Rome, 200o). Both collections stress the theoretical shift in the field of Christian history focusing on the discourse, both ancient and contemporary, of orthodoxy and heresy. Other representative works include Elizabeth Clark, The Origenist Controversy: The Cultural Construction of an Early Christian Debate (Princeton: Princeton University Press, 1992); Virginia Burrus, The Making of a Heretic: Gender, Authority, and the Priscillianist Controversy (Berkeley: University of California Press, 1995); Rebecca Lyman, "A Topography of Heresy: Mapping the Rhetorical Creation of Arianism," in Arianism after Arius: Essays on the Development of the Fourth Century Trinitarian Conflicts, ed. Michel R. Barnes and Daniel H. Williams, 45-62 (Edinburgh: T \& T Clark, 200o); and Teresa Shaw, "Ascetic Practice and the Genealogy of Heresy: Problems in Modern Scholarship and Ancient Textual Representation," in Miller and Martin, Cultural Turn, 213-36.

59. Shaw, "Ascetic Practice," 213.

6o. Patricia Cox Miller and Dale Martin, eds., The Cultural Turn in Late Ancient Studies (Durham, NC: Duke University Press, 2005). See, in particular, Dale Martin's introduction (1-24), Averil Cameron's "How to Read Heresiology" (193-212), and Teresa Shaw's "Ascetic Practice and the Genealogy of Heresy: Problems in Modern Scholarship and Ancient Textual Representation" (213-36). And, most 
no means a new phenomenon in this period, the difference was in how disputes were handled. As previously discussed, the imperial recognition of Christianity allowed for new (imperial) mechanisms to enforce right belief. One such tool was exile. Subsequently, the discursive tactics used to create a defensive orthodoxy were almost always informed by these new polemical realities. Thus, one arena in which the construction of competing orthodox identities works itself out is the literary imaginations of exiled bishops and those who remembered them.

The discourse of exile constructs, contests, and preserves orthodox identity in both ancient and contemporary works. ${ }^{61}$ Until very recently, the vast majority of scholarship on episcopal exile has taken one of two causal positions: a bishop is exiled either for theological or for political reasons. ${ }^{62}$ We see this most clearly demonstrated in debates over Athanasius's exiles as we started to explore above. Another example that draws together many of the points we have explored surrounding the academic study of clerical exile is evident in recent research on Hilary of Poitiers. ${ }^{63}$

The scholarly consensus is that Hilary was condemned at the Council of Beziers in 356. He was subsequently sent to Phrygia but traveled extensively for the duration of his short exile. Like Athanasius's first exile, the cause of Hilary's exile remains hotly debated. The traditional argument holds that Hilary was exiled for theological reasons, presumably related to his adherence to a pro-Nicene orthodoxy and his failure to condemn Athanasius at the councils held in Arles in 353 and Milan in $355 .{ }^{64}$ This explanation is often espoused by Hilary's modern biographers,

recently, see Todd Berzon, Classifying Christians: Ethnography, Heresiology, and the Limits of Knowledge in Late Antiquity (Berkeley: University of California Press, 2016).

61. I follow usage of the term discourse in Michel Foucault, The Archaeology of Knowledge: And the Discourse on Knowledge (New York: Psychology Press, 2002). He theorizes that our world is structured through linguistic practices that define the terms in which we understand the constructed world. There are social rules of exclusion and conditions by which dominant discourses articulate processes of constructing language and understanding. Discourse means more than simply speech or language. A discourse is a system of speech, thought, and action that informs and constitutes understanding, and all discourses presuppose a series of inherent relations of power. In other words, discourses are the categories of human experience that govern our thought world. Averil Cameron pointed to the usefulness of discourse analysis in early Christian studies in this influential work. See Cameron, Christianity and the Rhetoric of Empire: The Development of Christian Discourse, Sather Lectures 55 (Berkeley: University of California Press, 1991).

62. The Migrations of Faith Project (www.hrionline.ac.uk/sites/clericalexile) is the noted exception. The scholars involved in this project, including myself and Hillner, are starting to challenge previous studies that look for the causes behind individual exiles or the theological reasoning behind the persecution of individual bishops.

63. For a more developed discussion on Hilary's exilic discourse, see Barry, "Heroic Bishops."

64. This is also the most common interpretive framework used to view Athanasius's exiles. Khaled Anatolios, for example, uses Athanasius's exiles to frame the progressive development and coherence of his theological contribution to the larger Trinitarian controversies of the fourth century. See Anatolios, Athanasius: The Coherence of His Thought (New York: Routledge, 1998) and Athanasius (New York: Routledge, 2004). Ultimately, Anatolios places Athanasius firmly within a historical trajectory 
such as J. H. Reinkens and Paul Burns. ${ }^{65}$ The evidence used to support this position follows Sulpicius Severus's report of an imperial edict that states that all who did not agree to Athanasius's condemnation also ought to be banished: Edictum ab imperatore proponitur, ut qui in damnationem Athanasii non subscriberent in exilium pellerentur. ${ }^{66}$ John Cassian, in his work On the Incarnation, and Gregory of Tours, in the History of the Franks, also cite Hilary's staunch defense of orthodoxy as the principal reason for his exile. ${ }^{67}$

All are not persuaded by theological arguments, however. A second position holds that Hilary was deposed for political reasons, possibly due to treasonous acts. For example, he may have been linked to the brief revolt instigated by Silvanus in Gaul in 355, as was first posited by Alfred Feder in $1912^{68}$ and then accepted by Henry Chadwick in his 1959 encyclopedia entry. ${ }^{69}$ Hilary's possible treasonous activities were again described by Hanns Christof Brennecke ${ }^{70}$ and further explored by D. H. Williams in the 1980 os and 1990 s. $^{71}$ These claims are linked to a vague reference made by Hilary in his letter to Constantius. He states that both

that reaffirms Nicene terminology and contemporary reflections on its ongoing theological significance. A similar approach can be found in J. W. C. Wand, The Greek and Latin Doctors, ed. John H. Morgan (Bristol, ID: Wyndham Hall, 1990); M. E. Molloy, Champion of Truth: The Life of Saint Athanasius (New York: Alba House, 2003); Lewis Ayres, Nicaea and Its Legacy: An Approach to Fourth-Century Trinitarian Theology (Oxford: Oxford University Press, 2004); and George Dion Dragas, Saint Athanasius of Alexandria: Original Research and New Perspectives (Rollingsford, NH: Orthodox Research Institute, 2005).

65. J. H. Reinkens, Hilarius von Poitiers (Schaffhausen: Hurter, 1864). Many years later, Paul Burns made a similar argument in his The Christology in Hilary of Poitiers' "Commentary on Matthew" (Rome: Augustinian Patristic Institute, 1981), and then later built on it in his "Hilary of Poitiers' Road to Beziers: Politics or Religion?” Journal of Early Christian Studies 2, no. 3 (1994): 273-89.

66. Sulpicius Severus, Chron. 2 39.2.

67. John Cassian, De Incarn. 7.24; and Gregory of Tours, Greg. Hist. prol. 3.

68. Alfred Feder, Studien zu Hilarius von Poitiers III (Vienna: Hölder, 1912).

69. Henry Chadwick, "Hilarius von Poitiers," in Die Religion in Geschichte und Gegenwart, ed. Kurt Galling and Wilfrid Werbeck (Tübingen: Mohr, 1959), 317.

70. Hanns Christof Brennecke made the strongest argument for a link to treason, although many of Hilary's critics argue that his political importance prior to his exile is almost impossible to ascertain. See Brennecke, Hilarius von Poitiers und die Bischofsopposition gegen Konstantius II. Untersuchungen zur dritten Phase des arianischen Streites (337-361), PTS 26 (Berlin: de Gruyter, 1984).

71. D. H. Williams tempers the loose connection of Brennecke, Hilarius to Silvanus in Hilary of Poitiers, Contra Const., (see note 69) and points instead to passages in Hilary of Poitiers, De Syn., that address Hilary's misgivings about his episcopal network back in Gaul as well as explicate further what the false charges mentioned in Against Constantius might reveal. See Williams, "A Reassessment of the Early Career and Exile of Hilary of Poitiers," Journal of Ecclesiastical History 42, no. 2 (1991): 202-17. He affirms the argument that Hilary's support of Athanasius and failure to condemn the pro-Nicene supporter could not have been these charges, ruling out a theological connection, and concludes that Hilary must have been exiled for political reasons linked to his contentious relationship with Saturninus, his chief opponent at Beziers: "As a Western traditionalist, Hilary may have posed an obstruction to the attempts of Saturninus to create a common front among the Gallic bishops in support of the new religious policies of Constantius" (ibid., 212). 
the emperor and his Caesar, Julian, have been duped by false accusations made against the innocent bishop. ${ }^{72}$ What these false accusations are remains unclear. After reassessing the debate after the publication of Williams's article, Barnes concludes that the cause of Hilary's exile must ultimately "remain a mystery."73

Scholars do agree that Hilary remained in exile for only a short time (356-360) and that he returned to Gaul sometime soon after Julian was hailed Augustus of the West in 360. Again, it is unclear why Hilary returned. He may have received an imperial pardon, or he may have returned on his own volition. His ancient biographers provide little detail on the topic. Sulpicius Severus boasted that Hilary returned after he forced the emperor to repent, and Jerome simply writes that he returned after a short period in Constantinople. ${ }^{74}$ Unfortunately, his contemporary biographers are just as perplexed or misguided. Y.-M. Duval argues that many scholars erroneously reference Hilary's statement fugere mihi sub Nerone licuit as proof of the reason behind his return, which they understand to be a desire to avoid the emperor's insatiable desire to persecute orthodox Christians..$^{75}$ This revealing detail highlights how exiles are easily cast as persecuted, and therefore orthodox, figures by modern scholars who envision a past in which orthodoxy is already assumed.

These observations bring us to another important intervention made throughout this book: The manner in which scholars treat available sources reveals contemporary historical biases. Reconstructions of John Chrysostom's exile, in particular, have resulted in reinstating historical narratives of Christian triumph that overshadow a counter-narrative that viewed John as a heretic. Part of the problem appears to be the number of sources available to the historian. Unlike the paucity of texts concerning Hilary's exile and return, there is a plethora of material on the events surrounding John's exile.

Both Wendy Mayer and Geoffrey Dunn have convincingly argued that the surplus of evidence demonstrates a struggle between Johanite and anti-Johanite camps in Constantinople soon after John's departure and for a few years after his death. ${ }^{76}$

72. At the beginning of his brief letter, Hilary states, "Yet I am exiled not by an offense, but by a faction and by a synod's false messengers to you, devout Emperor, impeached, as I am, by impious men with no knowledge of guilty acts on my part. I have a witness of no light weight to my complaint in my religious lord Julian, your Caesar, who has endured through my exile more of calumny from the malicious than I of injustice; indeed, your Piety's letters are here at hand. But all the falsehoods of those who procured them for my exile are evident. ... Let me rely on that state of my knowledge and disclose that you, Augustus, have been cheated and your Caesar deceived" (Hilary of Poitiers, Contra Const. 2).

73. Barnes nevertheless briefly concedes that Hilary must have been deposed for theological reasons in Barnes, "Hilary of Poitiers," 129.

74. Sulpicius Severus, St. Martin 6.7; and Jerome, Chron.

75. Y.-M. Duval, "Vrais et faux problèmes concernant le retour d'exil d'Hilaire de Poitiers et son action en Italie en 360-363," Athenaeum 48 (1970): 253-66.

76. The Johanite controversy was relatively short-lived: John's name was restored to the dispatches in $418 \mathrm{CE}$, and his body was returned to Constantinople in 438; see Wendy Mayer, "Media Manipulation as a Tool in Religious Conflict: Controlling the Narrative Surrounding the Deposition 
The material that survives contains both positions. In addition to biographical accounts and ecclesiastical histories, a host of sermons circulated under John's name right before his second exile and soon thereafter. ${ }^{77}$ These pro-Johanite materials constitute a series of texts that take great pains to construct John as both a martyr and a saint..$^{7}$ Yet dissenting voices are also preserved, although sparingly. These voices surface roughly twenty-five to thirty years after John's exile, primarily in Socrates's Ecclesiastical History. ${ }^{79}$ Mayer cites a relatively recent attempt to discredit Socrates's account. Scholars blatantly favor the interpretation of Sozomen in his Ecclesiastical History over the narrative offered by Socrates. ${ }^{80}$ This trend is problematic for two reasons: Sozomen's account is written even later than that of Socrates, and Sozomen preserves a staunchly pro-Johanite slant. Mayer concludes that Socrates is so often dismissed in large part because he preserves a tradition that presents John in a less favorable light, and not without cause. Mayer writes:

Socrates' primary concern, in devoting an entire book to the events associated with John, is to document the most recent and most devastating schism within the church and to frame the individual at the centre of the schism, John, as a schismatic. Like Palladius he does not adopt a chronological approach, but rather present events in such a way that the causal factor behind the schism are brought to the front. It should be said at this point that for Socrates John is not the only person responsible for the schism . . . but the difference between his account and those of Palladius and ps.Martyrius lies in the degree of personal responsibility he attributes to John, something which the Johanite sources are at pains to avoid. ${ }^{81}$

It is not only his ancient biographers who are at pains to avoid calling into question John's orthodox legacy. Each biographer, ancient and contemporary,

of John Chrysostom," in Religious Conflict from Early Christianity to Early Islam, ed. W. Mayer and B. Neil, Arbeiten zur Kirchengeschichte 121, 151-68 (Berlin: de Gruyter, 2013). See also Geoffrey Dunn, "The Date of Innocent I's Epistula 12 and the Second Exile of John Chrysostom," Greek, Roman, and Byzantine Studies 45 (2005): 155-70, for a debate on the dating of the letter and significance of the pro-Johanite materials.

77. For a full review of the documents circulating under John's name, see Mayer, "Media Manipulation," 156-57. These sermons include psychosystemic material, such as the collection of thirty-eight Latin homilies and Augustine, C. Jul. op. imp. (CPL 35). Mayer notes the sermon On Holy Pentecost, which contains a combination of both authentic and inauthentic material circulating under John's name. Forty-six homilies assessed by Sever Voicu are also among this suspect group (CPG 4536). In particular, Wendy Mayer provides useful references regarding the scholarly conversation on this material in Mayer, "Media Manipulation," 156nn22-23.

78. Wendy Mayer, "The Making of a Saint: John Chrysostom in Early Historiography," in Chrysostomosbilder in 1600 Jahren: Facetten der Wirkungsgeschichte eines Kirchenvaters, ed. M. Wallraff and R. Brändle, Arbeiten zur Kirchengeschichte 105, 39-6o (Berlin: de Gruyter, 2008).

79. Socrates, Eccl. Hist. 6.1-21. Mayer, "Making of a Saint," 52-59, provides a chart that carefully describes the overlap and differences in details preserved by John's biographers.

8o. Here Mayer, "Making of a Saint," $40 n_{3}$.

81. Ibid., 40-41. 
appears to have a particular stake in the way John's exile is described, so each dismisses traditions that call into question John's legacy. The discursive politics involved in this battle over the correct reception of John's exile points to a larger historiographical dilemma: Episcopal exile appears to go hand in hand with the orthodox project.

As the figures of Hilary and John demonstrate, exile as a social phenomenon is difficult to disentangle from the highly polemical texts available to us. Instead of trying to delineate hard and fast rules to define whether or not an experience counts as an orthodox exile, here we will turn to the theological and political polemics at work in defining exile one way or the other. To be clear, this book is not chiefly concerned with issues of causation, although debates surrounding cause and effect are at times discussed. Instead, we will trace the development of exilic discourses through various literary texts. The contradictions and gaps in the sources become evident when we begin to see how the process of orthodoxy became so reliant on exilic discourse.

Pointing to the discursive nature of exile also makes us aware of the theological discourse used by Christian authors and the rhetoric of orthodoxy and heresy they deploy. This becomes most clear when we see how exilic discourse shifts once it is adopted into the biographical/hagiographical accounts. In the very moments at which exilic identities are sealed as orthodox, they also reveal the instability of the discourse. As discussed in the prologue, it appears almost simple for Tertullian to condemn flight in times of persecution as cowardly and contrary to one's identity as a Christian in the third century, and yet, by the early fifth century, exile is presented as evidence of one's access to truth-and, according to some biographers, a requirement for legitimacy. What is erased, however, is the fact that the orthodox were not the only ones to find themselves in exile. As we will explore in greater detail later, some of the most infamous heretics in Christian history-such as Meletius of Antioch and Eusebius of Nicomedia-also found themselves expelled from their communities. Exile is equally a symptom of heresy as it is a symptom of orthodoxy. In addition to discourse analysis, readers will encounter in this book alternative methods to study episcopal exile as a preventative measure to avoid reifying orthodoxy.

\section{EPISCOPAL EXILE AND DISPLACEMENT}

We will come across several theoretical concepts of displacement over the course of this book. These theories map the late ancient Roman Empire in inventive ways that draw tighter connections between the fleeing bishops examined here. The places to which bishops actually flee or into which they are imaginatively placed in retrospect create links between competitive topographical narratives. For example, Nicene narratives of utopian urban spaces such as Alexandria and Constantinople come into direct conflict when heretical bishops invade those borders. 
Likewise, the cities from which these bishops flee become a significant part of the story in how the bishops themselves are remembered. Exile, by its very nature, is a displacement. The exiled individual is removed from particular places: homelands, cities, episcopal sees, or imagined spaces of authority. The exile of bishops is therefore a productive place to apply space/place theory where relevant.

Current space/place theorists, especially human geographers, make a careful distinction between space and place. ${ }^{82}$ For instance, the modern concept of place is linked more directly to specific geographical locations than is the modern concept of space. While the ancients were equally fixated on space and on place, they moved between the abstract and the particular indiscriminately. In this book, space/place theory identifies topographical themes that link the imaginative process of the ancient concept of displacement. When we pay attention to the relationality, movement, and constructedness of displacement in the ancient world, it becomes clear that the social nature of space and place acts as an imaginative exercise for these ancient thinkers. For example, Alexandria and Constantinople are frequently imagined alongside one another to establish the boundaries of orthodox space over against Nicomedia. For these writers, place was not just a location-such as a geographical coordinate on a map-but was infused with meaning through the creative process of exilic discourse. The authors examined in this book created new topographical meanings for their exile as they moved across the ancient Mediterranean landscape. These places and spaces were then used as a polemical strategy to articulate an individual exile's own displacement, as well as the displacements of other exiles.

Recent spatial theories are therefore helpful for our examination of the past, as has been successfully demonstrated by Christine Shepardson in her work on the city of Antioch. ${ }^{83}$ Theorists consider, for instance, the ways in which spatial classification relies upon moments of transgression. These crossings are then used to reinforce identifiable boundaries. Homelessness, for example, creates a sense of out-of-placeness that troubles accepted meanings and practices about spaces. ${ }^{84}$

82. For a thorough assessment of the debates about space and place in various theoretical circles, especially during the 1970s, see Phil Hubbard, Rob Kitchin, and Gill Valentine, introduction to Key Thinkers on Space and Place (London: SAGE, 2004), 1-15.

83. Christine Shepardson, Controlling Contested Places: Late Antique Antioch and the Spatial Politics of Religious Controversy (Berkeley: University of California Press, 2014). For an overview of space/ place theory in late ancient studies, see, in particular, her introduction, 1-30.

84. Tim Cresswell, in In Place/Out of Place: Geography, Ideology, and Transgression (Minneapolis: University of Minnesota Press, 1996), cites as examples Mary Douglas, Purity and Danger: An Analysis of Concepts of Pollution and Taboo (New York: Praeger, 1966); A. R. Veness, "Home and Homelessness in the United States: Changing Ideals and Realities," Environment and Planning D: Society and Space 10, no. 4 (1992): 445-68; and L. Malkki, "National Geographic: The Rooting of Peoples and the Territorialization of National Identity among Scholars and Refugees," Cultural Anthropology 71, no. 1 (1992): 24-44. 
In a similar way, the refugee today creates a sense of panic as large numbers of foreigners (those who are not from this place) cross the carefully preserved and policed nation-state boundaries. The alien or outsider thus threatens preconceived notions of belonging. In an ancient context, then, authors relied on a similar distinction between outsiders and insiders to determine who had the authority to control strategic cities such as Alexandria, Antioch, Nicomedia, and Constantinople.

Conversely, the alien status of an exiled bishop could also work to a bishop's advantage. While the alien is often presented in a modern context as a source of anxiety, as Tim Cresswell has stressed, this status was infused with positive attributes in the ancient world. By challenging accepted social norms as an outsider, exiles were often identified as both aliens and persecuted victims. This connection between alienation and persecution allowed the exile to invoke all the cultural authority of the martyr tradition. Displacement, then, became a malleable concept that reinforced claims to orthodoxy at the very moments when it was most under threat.

Space and place theory will, therefore, help us to read and deconstruct the various forms of displacement we will encounter. ${ }^{85}$ As Juliette Day, Raimo Hakola, Maijastina Kahlos, and Ulla Tervahauta aptly surmise, "Places and spaces are not approached as neutral categories but as key factors in how individuals and groups construct their identities." ${ }^{86}$ Athanasius's construction of an Alexandrian orthodox city waylaid by heretics - men described as outsiders-helps him to reaffirm his own ownership over that space, even while absent from it. Athanasius's biographers will also resurrect this spatial concept in their narration of the past. When this strategy falls short during his own lifetime, Athanasius changes his approach and creates counterspaces, or heterotopias, that mirror the urban space he is incapable of inhabiting.

John Chrysostom's construction of the city of Constantinople as a Christian utopia also prepares us for the catastrophe that begins once its bishop flees from its borders. ${ }^{87}$ John and Palladius both ground their respective defenses of John's

85. Equally important for this study is how theory works to the advantage of the historian of late antiquity. Here I take seriously the observations made by Elizabeth Clark, who notes that late ancient historians "do not possess the type of documents on which social historians of modernity work, but high literary/philosophical texts that lend themselves well to theoretical analysis." See Clark, History Theory Text: Historians and the Linguistic Turn (Cambridge: Harvard University Press, 2004), 159. As Bruno Esteel remarks, "modernity was infatuated with questions concerning time and history whereas the post-modern obsession appears to be with questions pertaining to space and to geography." See Esteel, "Nonplaces: An Anecdoted Topography of Contemporary French Theory," Diacritics 33, nos. 3-4 (2003): 117-39. Esteel maps the so-called spatial turn in French theory through a critical lens of nonplace first espoused by Marc Augé.

86. Juliette Day, Raimo Hakola, Maijastina Kahlos, and Ulla Tervahauta, introduction to Spaces in Late Antiquity-Cultural, Theological and Archaeological Perspectives (New York: Routledge, 2016), 2.

87. The term utopia, coined by Thomas More, has its roots in classical literature. Fatima Vieira states that More's neologism stems from a compound of the Greek words ouk, "not," and topos, "place." It is both an affirmation and a denial of place, thus, a nonplace. The neologism also collapses "utopia" 
flight from Constantinople by contrasting the utopian vision of the city with the inevitable dystopia that takes place once John is expelled. As soon as the bishop is exiled, that perfected society breaks down. The catastrophe that sets in is the direct result of the bishop's departure and provides John and his biographers with a spatial rhetoric that capitalizes on apocalyptic images of torture and destruction. The subsequent upsurge of episcopal exiles in the surrounding episcopacies only reinforces John's condition as the most heinous of crimes enacted on the church. It is a bleak picture indeed.

A shift in perspective-and one that allows for a historiographical engagement open to the theoretical-allows us to encounter these ancient texts as literary production. Many of the texts assessed, for an example, are letters. In an effort to show the fluidity of exilic discourse, the genre of epistolography, in both Greek and Latin texts, serves as the primary medium through which this discourse of displacement is transmitted, although the larger literary genres out of which letters develop certainly vary. Put simply, the majority of the texts studied here are addressed to someone and sent somewhere else. Whether these letters actually reached their addressed recipients-whether the emperor Constantius II ever saw the letters Athanasius addressed to him, for instance-is a historical argument I do not intend to address here. What is of interest is how these letters constitute a shared cultural space that moves across the empire that can be used as evidence of a Nicene orthodoxy under persecution from its very inception by later ecclesiastical historians.

Moreover, epistolography is a favored genre used by authors to create imaginative spaces that are social and extremely productive, as well as to house descriptions of charged spaces of contestation. Additionally, authors took already theologically charged spaces like Nicaea or Rome and inserted their spatial authority into new spaces, such as Constantinople or Alexandria, in order shore up their boundaries. Displacement alongside the study of exile thus reveals how the process of making meaning moved across the ancient landscape as it carried the stories of fleeing bishops into different territories. This process becomes all the clearer when we see how orthodox spaces differ from heretical spaces.

(no place) into "eutopia" (the good place), which has the effect of idealizing nonspace. Vieira states, "by creating two neologisms which are so close in their composition and meaning-More created a tension that has persisted over time and has been the basis for the perennial duality of meaning of utopia as the place that is simultaneously a non-place (utopia) and a good place (eutopia)." See Vieria, "The Concept of Utopia," in The Cambridge Companion to Utopian Literature, ed. Gregory Claeys (Cambridge: Cambridge University Press, 2010), 4. 


\section{OUTLINE OF BOOK}

This book focuses on two bishops who are initially cast as heretics and sent into exile but who live on as champions of orthodoxy in both the Eastern and Western Roman Empire: Athanasius of Alexandria and John Chrysostom. I consider not only how these two bishops reflected on their own exiles but also how others represented them. In particular, I analyze the biographical reflections in the works of such figures as Gregory of Nazianzus, Palladius of Helenopolis, and the so-called Ps.-Martyrius. In order to construct a defensible orthodox identity, exiled bishops and their biographers invoke rhetorical formulas of suffering and alienation familiar from Christian martyrologies as well as Greek and Roman exilic literature. ${ }^{88}$ These strategies are so effective that biographical accounts, written soon after the death of these two figures, remember an orthodoxy already decided, however controversially.

For this reason, in chapter 1, we begin with an exploration of Athanasius's career outside of the city of Alexandria, in exile. It is in alternative spaces that he formulated a powerful exilic discourse that guaranteed not only Nicaea's legacy but also his own. By tracing the evolution of Athanasius's desert askesis, we are able to see how his version of Christian flight became a powerfully transient tale. ${ }^{89}$ So powerful that it was read and reread in several texts and spaces as Athanasius's fame-and his version of Christian orthodoxy - spread to cities across the Roman Empire and became central to the Nicene legacy in Constantinople.

In this first chapter, we explore Athanasius's reliance on and resistance to the empire. Athanasius's contentious relationship with Constantius II would link his experience to a past of imperial persecution. In a post-Constantinian period, however, empire was an effective tool used by all varieties of Christians to advance their causes. An ongoing, ambivalent relationship between Christian and imperial leaders was the subject of much debate among early Christian writers. In his early apologetic works, Athanasius displayed a certain level of deference to Constantius's authority. Once he was safely hidden in the desert and no longer under the emperor's gaze, however, Athanasius became much more critical of imperial meddling in ecclesiastical affairs.

Athanasius's interpretation of episcopal flight was soon picked up by Gregory of Nazianzus, who played a key role in ensuring the Athanasian legacy as an unquestionably orthodox one and who solidified the link between orthodoxy and exile. Chapter 2 examines how Gregory used the theme of Christian flight in two

88. Flower, Emperors and Bishops, 2-3, also makes this connection in his summary of the Dispute between Heraclianus and Germinius (Altercatio Heracliani cum Germinio) in which the bishop of Sirmium's public persecution of three pro-Nicene martyrs mimics the trials in the Acts of the Scillitan Martyrs.

89. I here refer to desert askesis as way to capture the progression of Athanasius's understanding of the ascetic life during his time in the desert. For a more detailed description, see the following chapter. 
orations to help rehabilitate his own failed career as the bishop of Constantinople. In these two works, Gregory constructs the orthodox bishop as a man forged in the fires of exile. Much like Cyprian, in his call for withdrawal, Gregory will rely on the temporary nature of Christian flight to promote the legacy of his heroes. Exile is only ever a temporary position for the truly orthodox. Gregory thus reaffirmed ecclesiastical authority within the civic centers of the Roman Empire and emphasized victory in those settings.

Constantinople, or the second Rome, would continue to play a major role in the growing battle over Nicene orthodoxy that remained tied to Alexandria in many complicated ways. John Chrysostom's troubles in Constantinople were due in no small part to his tense relationship with another Alexandrian bishop. As we will come to see in chapter 3, John will align Constantinople with Rome. He stresses that these two holy cities-and the bishops who appropriately reside within-are at risk when outsiders threaten to invade and undermine their authority. John describes what he sees as an assault. He focuses on the activities of his nemesis bishop, Theophilus of Alexandria, who unlawfully interfered in Constantinopolitan politics. Due to this invading bishop's heinous activity, John argues, the very sanctity of Constantinople-and possibly of other holy Roman cities-is under threat.

Familiar appeals to themes of persecution and tacit charges of episcopal malfeasance will initially frame his defense of his exile. When his appeals to Rome fail to secure a permanent return, John expands his epistolary efforts, although his exilic identities forged in his extensive letter collection produced between 404 and 407 would change significantly. The letters are modeled after classical themes and include references to long suffering, indifference, and even descriptions of luxurious retreat. As we will explore, the aim in this second phase of his defense is to produce an authorial position that justified his ongoing status as an exile. John's epistolary efforts perform what Owen Hodkinson has identified as a "macro-unit of composition" and what he sees as "a kind of literature in which the author can experiment with miniature correspondences, personas, chronological and thematic relations and intratextual allusion."9o

John was a masterful craftsman and appealed to a variety of literary models and themes to fashion his exilic self, but his efforts failed to secure his ultimate objective. He remained a bishop in exile with no end in sight. This outcome is seen most clearly in the two theological treatises composed for his most intimate correspondent, Olympias, in which he argues that exile is the natural state of all humanity. His experience in exile might appear at first sight different, and maybe even suspicious. Quite to the contrary, he concludes: all Christians are in exile.

90. Owen Hodkinson, "Better Than Speech: Some Advantages of the Letter in the Second Sophistic," in Letters: Classical and Late Antique Epistolography, ed. Ruth Morello and A. D. Morrison (Cambridge: Oxford University Press, 2007), 287. 
Yet John's final assessment of his two trips into exile was not tied to any one enemy or place but looked to classical examples of the long-suffering wanderer. As a perpetual exile, he would not have the satisfaction of a triumphant return, like Athanasius. Instead, he was resigned to wander outside of Constantinople and eventually died as an exile. John's biographers were thus faced with a particular challenge when reviving the memory of their failed hero. Chapter 4 looks at how John Chrysostom's biographers made use of alternate exilic themes to construct a localized exilic discourse that would eventually reinstate his memory as an orthodox one. Ps.-Martyrius, for example, insisted that Constantinople was only as holy as the bishop who resided in its space. The moment the bishop leaves the city, orthodoxy also takes flight. John's second biographer, Palladius of Helenopolis, went on to argue that the destruction of the city in the aftermath of John's removal proves the authenticity of its ousted bishop. In both instances, Ps.-Martyrius and Palladius argue that the bishop's memory must be defended and his body returned in order to restore the integrity of the city. This was no easy task, evident from Gregory's insistence on a triumphal return. It is only after both biographers align John's experience with Athanasius's exiles that his orthodoxy is eventually revived.

Ps.-Martyrius's Funerary Speech for John Chrysostom and Palladius's Dialogue on the Life of John Chrysostom are important not just for what they say but also for what they appear to mask. The rhetorical strategies used by those sympathetic to John's cause emphasize the important role administrative conduct plays in these texts, so much so that overt doctrinal positions are (or appear to be) absent from these texts. As Susanna Elm concluded, the overwhelming silence was due in no small part to the powerful influence these cities held in the empire, as well as the power asserted by their patriarchs. ${ }^{91}$ The bishop of Alexandria and the bishop of Constantinople may appear to operate in a doctrine-free zone, but by no means do they operate free of heresiological discourse. As Ps.-Martyrius's efforts reveal, orthodoxy and heresy are difficult to identify when exile becomes the marker of guilt. It therefore takes a discerning eye to truly distinguish a heretical flight from an orthodox one. Palladius must also argue that all was not as it appeared to be. Unlike Ps.-Martyrius, Palladius relies on a legacy of Christian flight that sees the triumphant return as the ultimate goal. Both men, however, will turn back to the city of Constantinople to finish their tale of Christian triumph. All true exiles must return to the city of truth-if only in death.

91. Susanna Elm, “The Dog That Did Not Bark: Doctrine and Patriarchal Authority in the Conflict between Theophilus of Alexandria and John Chrysostom of Constantinople," in Christian Origins: Theology, Rhetoric and Community, ed. Lewis Ayres and Gareth Jones, 68-93 (London: Routledge, 1998). She states, "Leaving modern scholarship aside for the moment, the issue at hand is precisely the ancient sources' treatment of the doctrinal aspects of the conflict: the moment Theophilus and John Chrysostom, the two protagonists, enter the scene, none of the sources closest to the events mentions doctrinal positions, as if Theophilus and John were operating in a 'doctrine-free zone'" (69). 
As John Chrysostom's failure will reveal, episcopal exile was not a clear indicator of orthodoxy. Christian flight remained a slippery category that continuously threatened to unmask episcopal cowards rather than prop up orthodox heroes. In chapters 5 and 6 , two counter-cases demonstrate why this might be. Like their so-called orthodox counterparts, Eusebius of Nicomedia and Meletius of Antioch were also exiled. Unlike Athanasius and John, these two exiled bishops did not live on as stalwarts of orthodoxy. Eusebius's exile is remembered as a just punishment for his support of Arian theology. Yet it is evident that Eusebius returns from his exile with even more power and influence. Meletius's exile, on the other hand, is marred by his controversial election by a so-called Arian community in and around Antioch. Unlike Eusebius, ecclesiastical historians often excuse Meletius for his earlier heretical leanings, which is due in no small part to his role in John Chrysostom's conversion. John must be remembered as orthodox, and so must all his mentors. The two powerful episcopal sees of Alexandria and Antioch remained at odds, and their struggle determined the parameters of the battle over orthodoxy. Antiochene politics were often in direct conflict with Alexandria, and that legacy of conflict appears to have traveled with John to Constantinople. ${ }^{92}$ Like the men we will explore here, the cities they flee to and from will also have a significant afterlife. As we will come to see, the space and place of exile will reveal a great deal about the making of a recognizably orthodox landscape.

The displacement and replacement of contested figures was not lost on ancient authors set on remembering particular places as orthodox and others as heterodox. We thus end this book with an evaluation of how the ecclesiastical historians became invested in shifting their reader's focus to the politics of the Eastern Roman Empire as the Christological controversies took off. Those champions of Nicaea-and its ultimate champion, Athanasius-were then resurrected in recognizable spaces of orthodoxy.

The exilic discourses explored here relied upon the both the subject of Christian flight and the topographical imaginings of displacement to construct a defensible mapping of the Nicene orthodox legacy. In the following pages, the reader will discover how the literary imaginings of fleeing bishops provided a new understanding of why Tertullian's critique, with which this book opened, was eventually displaced by Athanasius's promotion of the bishop in flight.

92. See chapters 2 and 3 . 



\section{Athanasius of Alexandria in Flight}

The desert has no doors, and all who wish pass through, but the Lord's house is enclosed with walls and doors, and brings to light the differences between the pious and the profane.

- ATHANASIUS, DEFENSE BEFORE CONSTANTIUS ${ }^{1}$

Then do walls make Christians?

-AUGUSTINE, CONFESSIONS ${ }^{2}$

In book 8 of his Confessions, Augustine of Hippo (354-430) describes in great detail a series of conversion narratives that lead to his own famous scene in the garden. Wandering men turn to the Christian faith as they mine the scriptures for Platonic truths or encounter fanciful stories of monks in the desert. Augustine decides to initiate his stories of conversions with the tale of Marius Victorinus. A famous fourthcentury orator and fierce defender of the Roman imperial cults for the majority of his long life, Victorinus eventually devotes himself to the careful study of the scriptures. As we might expect, his study results in his conversion. After Victorinus discloses this miraculous change of heart to a friend, he is immediately chided: "I shall not believe that or count you among the Christians unless I see you in the church of Christ." Victorinus, puzzled by such a statement, quickly retorts with a question that will occupy us in this chapter: "Then do walls make Christians?"

For Augustine and his friends, it would seem that walls do, in fact, make Christians. Holy spaces safely mark out those who are in and those who are not. This question was by no means a new one by the time Augustine wrote his Confessions: Athanasius of Alexandria made a similar argument nearly half a century earlier, although, for him, at least at an early moment in his career as the reigning bishop of Alexandria, the overarching issue was not the declaration of one's faith within

1. Athanasius, Apol. Const. 17. Edition: PG 25. Translation of this text is in consultation with Hanns Christof Brennecke, Uta Heilsand, and Annette Stockhausen, eds., Apologia ad Constantium, Lieferung 8 (Berlin: de Gruyter, 2006), with a few alterations or otherwise noted.

2. Augustine, Conf. 8.2(4). Edition: PL 32, CSEL 33, CCSL 27. Translation mine. 
the walls of the church but who owned the walls of the church. Those walls, he stressed, belonged to the Roman emperor. Athanasius was a fierce defender of those Roman imperial walls until, forced to flee from them, he was also forced to change his thinking. This miraculous transformation came about in the most unlikely of places: the Nitrian desert.

In this chapter, I focus on how the displaced bishop of Alexandria represented his own exile in two key polemical texts: Defense before Constantius and Defense of His Flight. In the first text, Athanasius began to think through the role particular spaces play in the identification and preservation of the Christian faith. As his position as an exile came into sharper focus, he shifted his argument away from the protection of imperial walls and toward the desert. By the end of his Defense before Constantius, Athanasius concluded that the desert, although a fearful place, is much safer than the walls of a church corrupted by a misguided emperor and, worse, heretical foes.

The desert, the space into which he fled, was then carefully constructed as a heterotopic politeia, which he defended in Defense of His Flight. ${ }^{3}$ In this second text, Athanasius elaborated on his theory of the desert to redefine and further defend his continued absence from Alexandria as accusations of cowardice and abandonment began to mount against him. The desert is an ascetic retreat rendered holy by other fleeing saints, who also find refuge there. It is not cowardly to flee, he argued, but this flight-his flight-is paramount to the survival of the Christian faith.

His description of this transformation finally solidified in his most famous work, the Life of Antony. ${ }^{4}$ The desert is no longer a temporary haven but a mirrored image of Alexandria made new and devoid of all the corrupting powers of heresy. As we will come to see, the walls of the Alexandrian churches quickly become too dangerous in the hands of Athanasius's enemies. The walls and doors then give way to the safety and, most importantly, the orthodox space of the desert, transformed into a holy city.

\section{HOW TO CONSTRUCT A MODEL CITY: ALEXANDRIA}

The actual space from which a bishop is exiled plays a significant role in how Athanasius and other fleeing men imagine themselves and how they will later be remembered. While Athanasius's first two trips into exile took him beyond the Alexandrian city limits, his literary prowess and identity as an exile began to flourish as he moved between Alexandria and the neighboring Nitrian desert. ${ }^{5}$ By the fourth century, Alexandria had already developed a long history in the politics

3. For a discussion of the meaning of the term politeia, see n. 40 below.

4. Athanasius, Vit. Ant. Edition: PG 26, col. 835-976. Translation: John C. Gregg, The Life of Antony and the Letter to Marcellinus (New York: Paulist, 1980) in consultation with Tim Vivian and Apostolos N. Athanassakis, trans., Athanasius of Alexandria: The Life of Antony. The Coptic Life, and the Greek Life, with Rowan A. Greer, Cistercian Studies Series 202 (Kalamazoo, MI: Cistercian, 2003).

5. The Nitrian desert is also known as Scetis (an archaic reference) and Wadi el-Natrun (its contemporary name). Coptic monastic communities are still active there today. 
of an expansive Roman Empire and an eroding Greek past. Founded by Alexander the Great in 331 BCE, it later became the capital of the Hellenistic world and exemplified the height of civilization, despite being invaded frequently and experiencing significant internal unrest. Between the restoration efforts made by Diocletian (284-305 CE) and the conquest of the Arab armies in the seventh century, Alexandria became a powerful and influential megalopolis within the Roman Empire. As a strategic stronghold, it boasted of its access to both a Mediterranean port and the Nile. That it was surrounded by two immense bodies of water that partitioned it from mainland Egypt no doubt led to its being referred to as "Alexandria ad Aegyptum" (Alexandria next to Egypt). ${ }^{6}$ Alexandria thus sat at the political center of the Graeco-Roman world. The colonnades and statues in the central streets, Canopica Way and the Soma, continued to remind visitors of its rich history.? The city was also an amalgam of intellectual, religious, and economic wealth that captured the literary imaginations of many ancient authors and further bolstered its reputation as a vibrant civic epicenter. ${ }^{8}$

The unified imperial presence in Egypt was also instrumental in promoting its affluence. Egypt's political structure was systematized due in large part to the reform efforts of Septimius Severus (193-211) and Diocletian (284-305) after him. As Philip Rousseau surmises,

In 199 or 200, Severus decided to allow Alexandria and to each metropolis (the urban center of a nome, or administrative district) a [boulē], or council, of its own. His purpose was undoubtedly to render more efficient the collection of taxes.... The districts around the towns were retained under the central control of the provincial government. But members of the new [boulai] quickly acquired responsibilities within the territoria, at least as agents of that government if not in their own right. The increased status of the towns encouraged in its turn the establishment in them of bishoprics. That ecclesiastical network and the new rapport between town and country paved the way for developments after Diocletian, when the metropoleis gained the added responsibility of administering the territoria themselves. ${ }^{9}$

6. This epithet is found in numerous ancient sources, including Ptolemy, Geog. 4.5.46; Strabo, Geog. 5.1.7; Philo, Prob. 125; and Athanasius, H. Ar. 17 712D.

7. The Canopica Way, a central avenue, cut through the city from the Moon Gate to the Sun Gate (east to west). The Soma was a central street that spanned from the harbor to Lake Mareotis (north to south). For the archeological evidence and excavation efforts, as well as a detailed description of the ancient layout of the urban setting, see Christopher Haas, Alexandria in Late Antiquity: Topography and Social Conflict (Baltimore, MD: John Hopkins University Press, 1997), esp. 18-44.

8. Walter Schneider cites the difficulties posed to reconstructions of the growth process of such a large-scale metropolis in antiquity. He provides a careful study of both the limitations and what sources are available. See Schneider, "Creating a Metropolis: A Comparative Demographic Perspective," in Ancient Alexandria between Egypt and Greece, ed. William V. Harris and Giovanni Ruffini (Leiden: Brill, 2004), 1-31.

9. Philip Rousseau, Pachomius: The Making of a Community in Fourth-Century Egypt (Berkeley: University of California Press, 1985), 3-4. For a thorough assessment of this transference, see Jacqueline Lallemand, L'administration civile de l'Egypte de l'avènement de Dioclétien à la création du diocèse 
The hierarchical structures set in place by these imperial reforms helped to centralize the Egyptian episcopal authority in Alexandria, although it was not until the fifth and sixth centuries that large-scale construction of churches and monasteries began there. ${ }^{10}$

The Alexandrian diocese was coveted and was the site of inter-ecclesial conflict from an early stage in Christian history. ${ }^{11}$ Control over this valuable city had its advantages as well as its risks. Because Alexandria was known as the breadbasket of the Roman Empire, ${ }^{12}$ misuse of the ports and the export of goods to the surrounding regions such as Constantinople and Rome were considered a treasonable act. The bishop of this city was, politically, a broker of stomachs as much as souls within the empire. Indeed, one of the first reasons cited for Athanasius's exile was his rumored meddling in the grain trade. ${ }^{13}$

The civic center was not the only space that captured the heart (or stomachs) of the empire. The Nitrian desert, roughly thirty to fifty miles south of Alexandria, also held its own acclaim. Archeological digs have produced evidence that a vibrant monastic community began to develop during the fourth and fifth centuries. ${ }^{14}$ The majority of these early monastic communities developed along the desert

(284-382): Contribution à l'étude des rapports entre l'Egypte et l'Empire à la fin du IIIe siècle et au IVe siècle (Brussels: Palais des Academies, 1964).

10. On the evidence available for the material growth and ecclesiastical ownership of land and church property of these sites, see Roger S. Bagnall, Egypt in Late Antiquity (Princeton, NJ: Princeton University Press, 1996), 289-303. The massive change that takes place during this period is often marked by the infamous destruction of the Serapeum in 392 CE. For a description of this event, see Johannes Hahn, "The Conversion of the Cult Statues: The Destruction of the Serapeum 392 A.D. and the Transformation of Alexandria into the 'Christian Loving' City,' in From Temple to Church: Destruction and Renewal of Local Cultic Topography in Late Antiquity, ed. Johannes Hahn, Stephen Emmel, and Ulrich Gotter (Leiden: Brill, 2008): 335-63.

11. Athanasius's rise to the patriarchate is intensely debated.

12. Haas, Alexandria, 42, estimates, "under the late empire, when Egypt bore the responsibility for provisioning the rapidly growing population of Constantinople, 36 million modii or approximately 220,000 tons of grain were sent annually to the new capital. This comes to roughly 5.5 million sackfuls, which would require 647 average-sized grain ships to sail annually from Alexandria's harbors."

13. See the interpretation of the charge in Athanasius, Apol. sec. 1:5; 9:3-4. For a relatively recent study on the grain trade in antiquity, including an assessment of grain-trade market intervention, see Paul Erdkamp, The Grain Market in the Roman Empire: A Social, Political, and Economic Study (Cambridge: Cambridge University Press, 2009), esp. 258-316.

14. For a review on the growth of Egyptian desert monasticism and its relationship to Athanasius, see David Brakke, Athanasius and Asceticism (Baltimore, MD: John Hopkins University Press, 1998), 80-141; and E. A. Judge, The Earliest Use of Monachos for "Monk" and the Origins of Monasticism (Münster: Aschendorffsche Verlagsbuchhandlung, 1977). On the complexity of literary evidence concerning Egyptian monasticism, see James Goehring, "The Origins of Monasticism," in Eusebius, Christianity, and Judaism, ed. H. W. Attridge and G. Hata (Detroit, MI: Wayne State University Press, 1992), 235-55. Desert monasticism, simplistically put, had three types: the eremitical (reclusive), the semieremitical (reclusive and communal), and the cenobitic (communal) life. These three ways of life are traditionally associated with the foundational leaders Antony, Ammoun and Marius, and Pachomius, respectively. 
strip adjacent to cultivated land and known as the "outer desert." ${ }^{15}$ Extending even further south is what was known as the "inner desert," an expanse of land beyond the valley that still contains remnants of ancient mines and quarries. ${ }^{16}$ For the most part, those who inhabited this region were criminals or slaves who worked in the mines and quarries; only a few zealous ascetics were said to have dared traverse this difficult landscape.

The harsh conditions of the Nitrian desert were not lost on early Christian authors, including Athanasius, for whose ascetic imaginations the outer and inner deserts became a literary backdrop. ${ }^{17}$ By the fourth century, these two significant spaces, the city and the desert, experienced both institutional transition and ongoing ecclesiastical conflict. The memory of imperial persecution haunted the avenues of the city and bled out into the surrounding desert sands. The battle over the Christian memory of Diocletian's persecution in North Africa (302-303), for example, resulted in the creation of two Christian factions based in Alexandria. Meletius, an elected bishop of Lycopolis, became bishop of Alexandria after the patriarch Peter fled into hiding sometime during the Diocletian persecution. ${ }^{18}$ In a controversial move,

Antony, as we will soon come to see, crosses these types. Each of the founders is linked to material remains that are still being excavated today.

15. Recent work by the Yale Egyptological Institute continues to uncover the archeological remains of Kellia and Pherme, later (fifth- and sixth-century) ascetic communities that developed further southwest of the Nitrian desert communities. For a working bibliography on these sites, see https:// egyptology.yale.edu/expeditions/current-expeditions/yale-monastic-archaeology-project-north-wadi-al-natrun/kellia-and-pherme. For the results of a survey of the land, see Tomasz Herbich, Darlene Brooks Hedstrom, and Stephen J. Davis, "A Geophysical Survey of Ancient Pherme: Magnetic Prospection at an Early Christian Monastic Site in the Egyptian Delta," Journal of the American Research Center in Egypt 44 (2007): 129-37.

16. Bagnall provides a thorough assessment of papyrological evidence to reconstruct the late antique desert environment. In the chapter where he explores the margins of Egyptian life, he notes the monastic preoccupation with the surrounding deserts and actual use of the desert by Roman officials: "The further reaches of the deserts had uses more commercial than the isolation demanded by the most ascetic monks. For one thing, they contained mines and quarries, sources of gold and of luxury building stone, like the brilliant porphyry beloved of Roman imperial architects" Bagnall, Egypt in Late Antiquity, 143-44.

17. Historical memories of the church in Alexandria are prevalent in later texts as well as in those explored in this chapter. In his chapter on the historical memories of the Coptic church, Tito Orlandi, cites the various ancient materials preserved by those in charge of collecting official documents and producing city chronicles: "Eusebius of Caesarea used such materials in his Ecclesiastical History, as did other later authors who dealt with the history of the Alexandrian patriarchate. While Sozomen is perhaps the best known and most important of these, other anonymous figures making use of the archive include the authors of the Historia acephala, the Index to the festal letters of Athanasius, the Passio Petri Alexandrini, the Passio Metrophanis et Alexandri." Orlandi, "The Coptic Ecclesiastical History," in The World of Early Egyptian Christianity: Language, Literature, and Social Context, ed. James E. Goehring and Janet Timbie (Washington DC: Catholic University of America Press, 2007), 4.

18. Also known as the "Great Persecution" in 303. It is common knowledge that Christians were persecuted in the period, prior to the Edict of Milan established under Constantine in 313. Various 
Meletius of Alexandria continued to act as a rival bishop even after Peter returned. ${ }^{19}$ As a response to his breach of conduct, a synod was convened, and Meletius was formally deposed by the council in 306. Persecutions soon resumed under Maximinus in 308, and Meletius was condemned to the mines in Palestine. He returned to Alexandria in 311 and started what is frequently referred to as the "Church of the Martyrs." After persecutions ceased, two competing Christian factions remained and continued to vie for control over the Alexandrian patriarchate. As many scholars have noted, this battle over the blood of the martyrs and the cultural authority of their memory shaped much of Athanasius's literary output and episcopal career. His story of a localized persecution will work to his advantage as he reads his own story into spaces long troubled by violence, even as he flees from them.

The birth of the Arian controversy in Alexandria also transformed how Athanasius would view the function of the desert over against the city. ${ }^{20}$ For it is in the desert that Nicaea's textual legacy was supplanted and received a new literary life. As Virginia Burrus has noted, Athanasius took great pains to condemn Arius's teaching well after his death and, at the same time, to create the legacy of the famed council of Nicaea in a new (literary) landscape. Burrus remarks: "Only after the crisis of Gregory's entry into Alexandria in late 338 did Athanasius rediscover 'Arius' (who had been dead since 335 or 336) and the usefulness of the label 'Arianism.'” ${ }^{21}$ Athanasius maligned Arius's memory and the memories of his supporters and sympathizers in order to construct his orthodox project in and around Alexandria. His subsequent polemical works capitalized on a genealogical rhetoric that pit the "Arian madmen" against the true inheritors of Nicene Christianity. ${ }^{22}$ This move then amplified the legacy of Nicaea and the fathers of the orthodox faith, a move we will continue to encounter in later chapters. The city of Alexandria and its neighboring desert changed the way later Christians would remember their theological heritage.

sources, both Roman and Christian, depict persecutions as sporadic and localized up until the middle of the third century. Our earliest Roman reference that associates the name "Christian" with persecution is found in a collection of Pliny's letters to and from the emperor Trajan in the early second century.

19. For Athanasius's perspective on the ongoing meddling in Alexandrian affairs (that they caused him trouble), see Athanasius, $H$. Ar. 3:78-81. Meletius of Alexandria is not to be confused with Meletius of Antioch, who is discussed in chapter 6 .

20. The infamous priest Arius (ca. 256-336), whose controversial teaching regarding the relationship between the Father and Son sparked an intense theological debate on the topic. Arius and his theological ideas were addressed at the ecumenical council at Nicaea in 325. For a detailed review of the development and legacy of Nicaea, see Lewis Ayres, Nicaea and Its Legacy: An Approach to FourthCentury Trinitarian Theology (Oxford: Oxford University Press, 2006).

21. Virginia Burrus, Begotten, Not Made: Conceiving Manhood in Late Antiquity (Stanford, CA: Stanford University Press, 2000), 60.

22. Athanasius, in De Synod. 13 and Orat. C. Arian 4, cleverly coins the phrase "Arian madmen" or Ariomaniacs, as an effective way to dismiss his enemies. 
Much like the Alexandrian city, the famous bishop of Alexandria has his own mythical beginnings. ${ }^{23}$ Born into a humble family, Athanasius showed promise from an early age and quickly rose through the ranks of ecclesial office. He became a deacon as soon as his age would permit, and Alexander, bishop of Alexandria from 313 to 328 , took him on as a trusted assistant and protégé. He is said to have been present at the Council of Nicaea in 325 and was almost immediately an ardent defender of its decrees. Upon the death of his mentor, Athanasius was named Alexander's heir despite the fact that, according to the Festal Index, he had not reached the canonical age for the episcopacy. ${ }^{24}$ From its very inception, Athanasius's career as the bishop of Alexandria was contested.

Fairly early on, then, Athanasius's enemies sought to oust the young bishop from his position of power. As discussed in the previous chapter, their efforts appeared to have been successful: between the end of Constantine's reign and the early years of Constantius's sole rule, Athanasius found himself in the western part of the empire, first in the city of Trier and then in Rome. Athanasius's first two periods in exile were spent outside of Egypt. Given the contradictory reports found in the primary sources, the precise reasons for these flights are difficult to pin down. What is clear is that Athanasius took advantage of his displacement and its literary possibilities to construct a sympathetic and powerful identity. Exile, Athanasius argued, is synonymous with persecution. He construed himself as a victim, though in reality he was hardly a passive one. It is clear that by adopting the identity of an exile, Athanasius ensured his legacy as an orthodox bishop whose circumstances behind closed walls eventually drove him to the desert.

\section{IF THESE WALLS COULD TALK: DEFENSE BEFORE CONSTANTIUS}

Athanasius's discourse on his exile and the desert begins in his Defense before Constantius. The defense is particularly difficult to date, but T. D. Barnes, building on the work of Archibald Robertson (1892) and J.-M. Szymusiak (1958), suggests that the defense was written in two stages: chapters 1-26 between 353 and 355, and chapters $27-35$ in $357 .{ }^{25}$ In the decade prior to his third exile (346-356), Athanasius composed the first stage in order to defend himself against a series of charges, both long-standing and new. The second stage signaled a change in both his dealings with the emperor and his view of the desert.

23. Gregory, Orat. 21. Edition: SC 247. Translation: $N P N F 2$ 7. I will discuss this source later in this chapter. See also Rufinus, Eccl. Hist. 10.15; Socrates, Eccl. Hist. 1.15; and Sozomen, Eccl. Hist. 2.17.5-13.

24. For a thorough and recent discussion on the history and difficulty in assessing the Index and the assembly of the surviving Festal Letters, see David M. Gwynn, Athanasius of Alexandria: Bishop, Theologian, Ascetic, Father (Oxford: Oxford University Press, 2012), 7-8.

25. Barnes, Athanasius and Constantius, 196-97. For full biographic reference for Robertson and Szymusiak, and a description of the argument, see Barnes, Athanasius and Constantius, 302nn3-4. 
By the time Athanasius completed the text, presumably during his third exile into the desert, it became evident that his hopes of securing imperial sympathy would go unfulfilled. The beginning of the text strikes a conciliatory note and is sympathetic to the emperor's position as a misinformed mediator and defender of sacred space. By its end, it is clear that Athanasius's opinion of the emperor has shifted significantly, as have his opinions of where orthodox space might be found.

Written in the form of a letter, the text begins with a detailed response to four charges the so-called Arians laid against Athanasius. First, he is accused of conspiring with the youngest son of Constantine, Constans (chaps. 2-5), and then of seeking an alliance with Magnetius after the conspiratorial death of Constans (chaps. 6-13). ${ }^{26}$ If these treasonous activities were not worrisome enough, Athanasius's enemies also accuse him of making use of a church in Alexandria that had not yet been sanctioned by Constantius (chaps. 14-18). Finally, Athanasius must answer to the charge that he failed to adhere to a summons to appear before Constantius to answer to these charges and more (chaps. 19-27). It is in response to the latter two charges that Athanasius begins his discussion on the desert. As we will soon see, the further he ventures away from city and moves into the desert, the more his relationship with Constantius deteriorates. The desert is infused with different meanings, as Athanasius lays out his defense. And it is in the desert that Athanasius begins to articulate why the Alexandrian churches are no longer safe for Christian worship and the proof of Christian authenticity.

Athanasius first mentions the desert in chapter 14, where he defends his decision to use the unsanctioned Alexandrian church in the first place. The week prior to the Easter celebration, the crowds had grown too large for the approved spaces of worship. In a moment of desperation, Athanasius decides to turn to the larger space, but only after the worshippers had threatened to go into the desert:

When the churches were too small, and the people so numerous as they were, and desirous to go forth into the deserts, what should I have done? The desert has no doors, and all who wish pass through, but the Lord's house is enclosed with walls and doors, and brings to light the differences between the pious and the profane.... The charge would have been much greater if we had passed by the place which the emperor was building and went into the desert to pray. (Athanasius, Apol. Const. 17, emphasis mine)

As we see here, Athanasius states that the desert is hardly an appropriate place for worship and prayer. It has no doors-anyone might pass through. It does not even have any walls. And we hear the familiar refrain: Athanasius insists that walls do, in fact, make Christians. They are all that separate the pious from the profane.

26. Magnetius was an ambitious general whose rebellion cost him his life. For a description of his role in Athanasius's third exile, see Barnes, Athanasius and Constantius, 101-8. 
Athanasius goes on to make clear that a church belongs to the emperor whether it is dedicated or not. In a deferential moment, he insists that it is not the faithful who build a church, but the emperor. In fact, the people prove their allegiance to the emperor by worshiping in the church rather than in the desert. He goes on to assure the emperor that it is, of course, also in the emperor's church that the faithful dedicate their prayers to his safety and health. The walls and doors of the church within the city are therefore conducive to (imperial) allegiance and piety. The desert, by contrast, promotes chaos, not least because it lies beyond the view of the imperial authorities.

For they know that here [in the church], prayer is lawfully offered, while a suspicion of irregularity attaches to it there [in the desert]. Unless, indeed, no place proper for it existed, and the worshippers dwelt only in the desert, as was the case with Israel; although after the tabernacle was built, they also had a place set apart for prayer... I am blamed ... for the keeping of your laws. Heavier had been the blame, and more true had been the charge, had we passed by the place that the emperor was building, and gone forth into the desert to pray. (Athanasius, Apol. Const. 17)

This characterization of the desert as a fearful place not controlled by the emperor is particularly striking: in the second half of the defense, written during his exile, Athanasius argues that it is not the desert that is dangerous, but the very same walls he defends here. Those who now control the walls of the Alexandrian church have forced the faithful out, and all that remains is the desert.

Prior to this conclusion, however, Athanasius explains how he has now found himself in that very space he so feared before. He begins by countering the fourth charge: that he refused to adhere to a summons to appear before the emperor. He contests that he never received a formal letter to appear. Still more, it seems that no physical letter was ever delivered. Instead, a simple verbal summons was all that was relayed to him. The absence of something tangible made him highly suspicious: "Seeing they produced no letters from you, [I] considered it improbable that a mere verbal communication should be made to them" (Athanasius, Apol. Const. 24). This method of delivery alone caused him to hesitate, but his suspicions were exacerbated because the messengers themselves were questionable: "I confess-I say it boldly-I was suspicious of them. For there were many Arians about them, who were their companions at table and their counselors" (Athanasius, Apol. Const. 25). Athanasius concludes that he should not be held responsible for his initial hesitancy. If these messengers had simply produced a written document, he would have happily complied.

In addition to citing the dubiousness of the request, Athanasius declares that he dared not abandon his flock: "You know, for you have read the scriptures, how great an offense it is for a bishop to desert [katalimpanein] his church, and to neglect [amelein] the flocks of God" (Athanasius, Apol. Const. 26). Tertullian's warning and Cyprian's initial concerns regarding flight and cowardice both linger 
in the background. Both authors criticize Christian leaders who willingly abandon their charges during times of persecution, ${ }^{27}$ which would be by far the most heinous of crimes: "For the absence [apousia] of the shepherd gives the wolves an opportunity to attack the sheep. And this was what the Arians and all the other heretics desired, that during my absence [apousia], they might find an opportunity to entrap the people into impiety" (Athanasius, Apol. Const. 26).

In order to stress the perils of leaving his flock, Athanasius invokes the language of flight, a theme he will continue to build on throughout his exilic discourse: "If then I had fled [phygōn], what defense could I have made before the true bishops? Or rather before Him Who has committed to me His flock? He it is Who judges the whole earth, the true King of all, our Lord Jesus Christ, the Son of God. Would not everyone have rightly charged me with neglect of the people [amelein tōn laōn]?" (Athanasius, Apol. Const. 26). Here Athanasius lays the groundwork for his ultimate defense. He insists he was reluctant to leave but ultimately could not ignore the summons. Thus, it was only against his better judgment that he decided to depart from Alexandria. Although he knew leaving would result in chaos, he trusted Constantius's ability to hear him out. His initial intuitions proved to be right. We soon learn that Athanasius never made it to court. En route, he traveled through the desert (tên erèmon exelthontos), where he heard new rumors that his enemies had begun to persecute his flock, and this led him to abandon his journey altogether.

What remains a mystery is why Athanasius chose to travel through the desert on his way to Constantius. This was hardly a direct route, given that the Nitrian desert was south, not north of Alexandria. Nevertheless, to convey the gravity of the situation, Athanasius once again turns to the desert for inspiration. He recounts for Constantius a particularly gruesome event. In his absence, the people do not pray in a church but once again decide to worship in the desert: "While the brethren were praying during Easter and on the Lord's day in a desert place outside a cemetery [en erēmō topō pleion trischilionn], the general came upon them with a force of soldiery, more than three thousand in number, with arms, drawn swords, and spears" (Athanasius, Apol. Const. 27). The desert quickly dissolves into chaos, as we might expect. The army violently mistreats the women and children of his flock. Furthermore, they violate dedicated virgins and banish many aged bishops. Athanasius emphasizes that these travesties would never have been allowed to happen if he had remained in Alexandria and his charges were permitted to worship behind the safety of the walls of a church. Yet he now finds himself helpless to remedy the situation.

In the second half of the defense, the desert slowly comes into sharper focus, for it is in this space that Athanasius finds himself sequestered when he learns that Constantius has sent out an order for his arrest. He includes two letters as proof.

27. See the prologue for a more developed discussion on the views of both Tertullian and Cyprian on flight during times of persecution. 
The first letter from Constantius is addressed to the citizens of Alexandria, and in it, the emperor encourages the Alexandrians to abandon their alliance with "that pestilent fellow Athanasius" (Athanasius, Apol. Const. 30) and pledge to follow Athanasius's rival, the venerable George-namely, George of Cappadocia, a rival (and an Arian bishop at that) who has taken control of the Alexandrian see. ${ }^{28}$ Athanasius finds himself trapped between a hostile emperor and his Arian enemies.

In the second letter, composed to the princes of Auxumis (in the northeastern territory Africa), Constantius depicts Athanasius as a deplorable character who corrupts the lowly and whose loyal followers have been consistently condemned by the emperor. Constantius then calls for Fermentius, the bishop of Auxum, to appear before the venerable George in Alexandria to defend his right to the appointment given to him by Athanasius. It is a wonder that Athanasius includes the letter at all. The emperor again impugns Athanasius and states he is nothing short of a pestilent criminal. He describes Athanasius as "a man who is guilty of ten thousand crimes; for he has not been able fairly to clear himself of any of the charges brought against him, but was at once deprived of his see, wanders about destitute of any fixed abode, and passes from one country to another, as if by this means he could escape his own wickedness" (Athanasius, Apol. Const. 31, emphasis mine). ${ }^{29}$ Curiously, it is Athanasius's wanderings, or flights into exile, that serve as evidence for his unstable character.

Prior to this point, Athanasius has described his flight into the desert as an obedient act: he was simply obeying orders. He will consistently make the argument for his earlier flights into exile as well. Constantius, on the other hand, interprets his flight as evidence of his criminal activity and questionable character. Athanasius is a wanderer, a fugitive who is incapable of escaping his crimes. Sylvia Montiglio argues that the wanderer (planetes or aletes) is an all-encompassing identity that can mean someone who moves about in an unstructured manner, a person who moves away from a path, or one who moves outward or away from a particular center. The latter interpretation, according to Montiglio, describes someone who is expelled from his or her home, community, and belongings; in other words, the wanderer is an exile. This distinction differentiates between those who wander and those who travel in the ancient world.

28. The link to Cappadocia is significant for Athanasius. George is an outsider, as is his replacement, Gregory, who is also from Cappadocia. It appears as if no good can come from this part of Asia Minor. In another discussion, Athanasius also notes that Auxentius of Milan comes from Cappadocia (Athanasius, H. Ar. 75.1). In each case, "Cappadocia" is used as a signal for "outsider." Prior to the Cappadocian fathers, this location appeared to be a seedbed of so-called Arian theology. Later ecclesiastical historians picked up on this language of location when discussing Eusebius of Nicomedia. In the minds of the pro-Nicene writers, one's homeland makes all the difference in the battle over orthodox landscape. See chapter 5 for fuller discussion of the city of Nicomedia.

29. This description alludes to a number of infamous classical characters, such as Oedipus, Tydeus, Peleus, and Telamon. 
Constantius's vilification of Athanasius's flight involves allusion to classical motifs concerning the suspicious nature of such wanderers. The wanderer carries both positive and negative characteristics in classical literature. While Odysseus typically stands as the archetype of praiseworthy wandering, Oedipus is the antiwanderer. ${ }^{30}$ Odysseus often tells lies, but he does so for noble purposes, as, for example, when he returns to his homeland and disguises himself as an old man and an exile in order to win back his home from his wife's suitors. He is cunning and careful and gains knowledge through his travels. Oedipus, however, is doubly abhorrent. He not only wanders, but he also wanders without knowledge. He wanders about Thebes and is expelled from his homeland only after he kills his father and mistakenly marries his mother. Like Oedipus, Athanasius's guilt is confirmed by his rootlessness. He too has no fixed abode but wanders (alatai) and, like Oedipus, moves from one place to the next as if he could escape his crimes, which, the emperor insists, he is clearly incapable of doing.

In order to counter such a damning conclusion, Athanasius invokes the language of persecution to reinterpret his sinister wandering as a righteous exile. He, like Odysseus, is cunning and carries with him the truth. The heretics are the real criminals. They persecute the faithful and take full advantage of Athanasius's absence. Still worse, these heretics dare to use imperial forces to support their activities. By making this point, Athanasius implies that it is under Constantius's directive that such persecution is necessary.

These men alone not only did not fear to strip and to scourge those undefiled limbs, which the virgins had dedicated solely to our Savior Christ; but, what is worse than all, when they were reproached by everyone for such extreme cruelty, instead of manifesting any shame, they pretended that it was commanded by your piety. Such a deed as this was never heard of in past persecutions: or supposing that it ever occurred before, yet surely it was not befitting either that virginity should suffer such outrage and dishonor, in the time of your majesty, a Christian, or that these men should impute to your piety their own cruelty. Such wickedness belongs only to heretics, who blaspheme the Son of God, and who do violence to His holy virgins. (Athanasius, Apol. Const. 27, emphasis mine)

While the abuse of virgins is certainly a crime, the misuse of the emperor's words in order to justify the cruel treatment of the faithful is more deplorable. Constantius is far from innocent, however, as the letters above imply. Yet Athanasius reserves any overt criticism. He merely presumes that the emperor is simply ill advised and has been duped.

Athanasius then further mobilizes the chaos of the desert to his advantage in the concluding chapters of the defense. The heretics corrupt the city as they continue to push the faithful into the desert. While the emperor does encourage the

30. Sylvia Montiglio, Wandering in Ancient Greek Culture (Chicago: University of Chicago Press, 2005). 
expulsion of bishops to the outskirts of the city (in hopes of quelling civic unrest), the Arians and their civil counterparts go a step further and force the bishops into the desert, those "unfrequented and frightful places" (Athanasius, Apol. Const. 32). Even if Constantius is not fully aware of the level of abuse the Arians take against the faithful, a full-scale imperial persecution has once again begun.

Finally, Athanasius reinforces his argument by building on the language of persecution. He alludes to Paul's flight from Damascus (Acts 9:25) and states that he should hide for a time, as the scriptures dictate.

O blessed and pious Augustus, what would you have wanted me to do? Should I have come to you while my enemies were inflamed with rage against me and were seeking to kill me; or, as it is written, to hide [apokrybēnai] myself a little, that in the meantime they might be condemned as heretics, and your goodness might be shown to me? . . It would neither have been becoming in me to surrender and give myself up that my blood might be shed, nor in you, as a Christian emperor, to have the murder of Christians, and those bishops, imputed to you. ... It was therefore better for me to hide [krybennai] myself and to wait for this opportunity. (Athanasius, Apol. Const. 34-35, emphasis mine)

Athanasius still appears to give the emperor the benefit of the doubt, stressing that Constantius must be ignorant of the events that are transpiring. For Athanasius's purposes, Constantius's misguided actions suggest he is guilty only of attempting to restore order and certainly not of direct persecution. Or is he? Athanasius's repeated stress upon the epithet "Christian" starts to lose its meaning as the language of persecution recalls an all-too-present past of imperial persecutions. ${ }^{31}$ Whether or not the emperor is one among the many wolves in sheep's clothing, he has certainly lost control of his Alexandrian representatives.

In Athanasius's Defense before Constantius, then, we see the slow development of his use of the desert to think through his defense of his flight from Alexandria. The text begins with a hard line: the desert is a dangerous place and certainly no place for Christian worship. By the end of the text, the chaos of the desert serves as proof of the unruly state of the Alexandrian city and the churches found within its care. The faithful are forced out and flee to the desert under threat of persecution. Although a dangerous place, the desert begins to take on new meaning, and flight becomes the only means of survival.

As the meaning of the desert evolves, so does Athanasius's interpretation of his exile. At first, he abhors the idea of leaving his beloved city and flock. He

31. Athanasius, H. Ar. 68-71, would later develop a more damning picture in which his characterizations of Constantius are very similar to those made by Hilary of Poitiers, namely, that Constantius is a villain akin to biblical villains, such as Pilate. Exile is again cited as a particularly horrible act. Richard Flower also makes this connection in his "The Emperor's New Past: Re-Enactment and Inversion in Christian Invectives against Constantius II," in Unclassical Traditions, volume 1, Alternatives to the Classical Past in Late Antiquity, ed. Christopher Kelly, Richard Flower, and Michael Stuart Williams (Cambridge: Cambridge University Press, 2010), 34-35. 
protests that his departure would be akin to abandonment. Yet his deference to the emperor compels him to leave his post. His flight is an obedient act. But obedience quickly turns into defiance as he slips beyond the reach of his enemies. In the end, he decides, walls and doors will do him no good, but the desert will provide him all the safety he needs.

\section{A WALL-LESS DESERT: DEFENSE OF HIS FLIGHT}

Constantius is rarely mentioned in Athanasius's Defense of His Flight (c. 357). Athanasius is now beyond the emperor's line of sight, and this second polemical text responds directly to all those who might feel abandoned by the fleeing bishop by invoking a long-standing biblical tradition of men who flee into the desert during times of persecution. Athanasius is focused on rebutting the charge of cowardice and placing blame upon his persecutors, whom he claims are false Christians. As before, heresy is intertwined with imperial politics: Athanasius appeals to the empire to identify his enemies. Those who abuse imperial power, he concludes, do not have the right to the title "Christian."

Athanasius counters the charge of cowardice by accusing his Arian enemies of filial impiety (asebeia), framing the accusation with the commandment "Honor your father and your mother" (Athanasius, Fug. 2.9). Burrus has previously pointed out that pious obedience to the tradition of the fathers serves as a litmus test for Athanasian orthodoxy, which reveals one's true identity as either a Christian or a heretic. ${ }^{32}$ According to Athanasius, those who reveal themselves as disloyal sons risk incurring divine judgment: "He that curses his father or his mother-let him die the death" (Athanasius, Fug. 2.9).

He then begins this defense by arguing that the so-called Arians dishonor (atimian) the memory of the martyrs by mimicking the violence of imperial persecution. George of Cappadocia, Athanasius's chief rival to the Alexandrian patriarchate, for example, uses imperial troops as well as heretics to enforce religious obedience: "George, that abandoned person . . . stirred up against them the commander Sebastian, a Manichee; who straightaway with a multitude of soldiers with arms, drawn swords, bows, and spears, proceeded to attack the people, though it was the Lord's day" (Athanasius, Fug. 6.21). Here we see multiple causes for alarm. Not only do the Arians collude with imperial officials and attack the defenseless, but they do so with the aid of a Manichean and on the Lord's day. To further stress this heinous behavior, Athanasius briefly recounts his competitor's atrocious treatment of a group of virgins, saying, "Having lighted a pile, he placed certain virgins near the fire and endeavored to force them to say that they were of the Arian faith; and when he saw that they were getting the mastery and cared not for the fire, he immediately stripped them naked and

32. Burrus, Begotten, Not Made, 63. 
beat them in the face in such a manner that for some time they could hardly be recognized" (Athanasius, Fug. 6.24). Just as in the previous letter, imperial thugs conspire with heretics.

This conspiratorial relationship and continued excessive violence against the most vulnerable should be reason enough to support Athanasius's decision to flee, but he does not stop there. In the second half of the treatise, Athanasius stresses that the authority of the martyr's body, once the paradigm of Christian orthodoxy, is capable of saying only so much; the bishop (and all those who have fled before him) must continue to confess and, more importantly, enforce the truth. Much like his earlier allusion to Paul's flight from Damascus, Athanasius points to other scriptural examples of fleeing saints in order to reconstruct a tradition of flight worthy of emulation:

What will they do when they see Jacob fleeing from his brother Esau, and Moses withdrawing into Midian for fear of Pharaoh? What excuse will they make for David, after all this idle talk, for fleeing from his house on account of Saul, ... [and] the great Elijah, after calling upon God and raising the dead, hiding himself for fear of Ahab and fleeing from the threats of Jezebel? At which time the sons of the prophets, when they were sought after, hid themselves with the assistance of Obadiah and lay concealed in caves, ... the disciples also withdrew and hid themselves for fear of the Jews; and Paul, when he was sought after by the governor at Damascus, was let down from the wall in a basket, and so escaped him. (Athanasius, Fug. 18)

The implication in this passage is that these men survive so that others might follow their behavior rather than suffer the same fate of the martyrs who remain victims rather than models to live-or die-by. ${ }^{33}$

Athanasius invokes these exemplary men in flight to intentionally undercut the authority of the martyr. Those beaten or cruelly treated are presented as helpless victims. He describes the abuse of these men and women in detail in order to highlight the base nature of their abusers. The passive victims are to be pitied but not necessarily emulated. Conversely, the actions of the saintly fathers, or those who survive, stand as the superior example of Christian piety. In a bold statement, Athanasius writes:

The flight to which they [the saintly fathers] submitted was rather a conflict and war against death. For with wise caution they guarded against these two things; either that they should offer themselves up without reason ... or that they should willingly subject themselves to the reproach of negligence, as if they were unmoved by in the tribulations they met with in their flight, and which brought with them sufferings greater and more terrible than death. (Athanasius, Fug. 17.18, emphasis mine)

33. James Ernest points to Athanasius's use of paradeigma as the primary tool with which to bolster his defense: "His exempla are taken not simply from past events and definitely not from events he made up himself but almost always from the paradigmatic narrative of scripture." Ernest, The Bible in Athanasius of Alexandria (Leiden: Brill, 2004), 196. 
The masculine virtue of fortitude is thus cultivated under the pains of persecution and, according to Athanasius, this suffering is much greater than that of the martyrs.

As a bishop in exile, Athanasius's authority is built on the shoulders of all those saintly fathers who fled before him. Paternal generativity, as Burrus states, relies on a set of discursive strategies and rhetorical performances that blur gender roles and create queer crossings. ${ }^{34}$ His flights into exile serve as only one type of performance used to forge a distinctly orthodox patrilineal legacy over and against an effeminate heresy. In short, orthodoxy is concretized by the paternal generativity that is born in exile.

In his other polemical texts, paternal generativity is also linked to the legacy of Nicaea. ${ }^{35}$ Burrus touches on Athanasius's third flight into exile to state that his development of the city in the desert in the Life of Antony is particularly effective. His "'flight' from the city can always be retooled as the ascetic 'withdrawal' through which the city is produced anew (Apologia de fuga); 'exile' helps create a flexibly transcendentalized sense of place." ${ }^{36}$ As we will come to see, this transcendentalized sense of space is of central importance to Athanasius's larger exilic discourse.

In this particular text, however, Athanasius invokes paternal generativity to place himself among a male lineage of holy men who have fled during times of persecution, men such as Abraham, Moses, David, and, most importantly, Christ. These saintly men fortify their manly courage through the ongoing trials of persecution while in exile, and their authority is strengthened by the proper use of that time and space. Athanasius continues:

Behold, therefore, in that they were thus engaged in conflict with their enemies, they passed not the time of their flight unprofitably, nor while they were persecuted did they forget the welfare of others-but as being ministers of the good word, they grudged not to communicate it to all men, so that even while they fled, they preached

34. Burrus examines Athanasius's exiles in the context of her discussion of how Nicene orthodoxy took shape through the gendered language of the aptly named "church fathers," noting that "Nicaea' enters Athanasius's texts on the heels of 'Arianism,' but initially with faltering steps" (Burrus, Begotten, Not Made, 61). Nicaea only enters into Athanasius's polemical works after Gregory, his rival, enters into Alexandria.

35. It is outside of the Defense of His Flight that Burrus most clearly sees the link between patrilineal lineage and claims to doctrinal purity. She first sees the development of Athanasius's defensive stance in the Encyclical Letter of the Council of Egypt (a letter that was circulated widely during his third exile). Nicaea is juxtaposed with Tyre in a way that couches Athanasius's own experience within his imaginings of a so-called orthodox tradition. On the Council of Nicaea is the first text to identify those who attended Nicaea as "fathers." The introduction of paternal terminology is a key factor in the evolution of Athanasius's concept of Nicaea: "Since those who attended Nicaea are in a conspicuous sense the transmitters and agents of the divine 'tradition' or 'paradosis', that is, of the 'teaching' or 'didaskalia' that is handed down from 'Fathers to Fathers', they themselves are designated with this title, which is surely the highest that Athanasius has to bestow" (Burrus, Begotten, Not Made, 61).

36. Ibid., 75 . 
the Gospel and gave warning of the wickedness of those who conspired against them, and confirmed the faithful by their exhortations. (Athanasius, Fug. 21.14)

These fathers do not suffer silently, nor do they waste their time in exile. They openly proclaim the gospel, speaking not just with their bodies, as the dead martyrs do, but with their lively tongues. The saintly fathers are preserved so that their testimony might affirm the message of right belief.

It is unsurprising, then, that Athanasius identifies the divine logos as among the exemplary characters of flight. The logos hides himself within flesh for the sake of humanity and flees from his enemies in order that others might follow his example: "Thus the Lord acted, and thus he taught" (Athanasius, Fug. 13.7). James Ernest argues that, for Athanasius, the Son is the primary exemplum, the principal source of human conduct; he is the logos of the Father enfleshed. ${ }^{37}$ By taking on the human body, he experiences persecution just as the saints do. The Son's flight is thus paradigmatic of the flight of all who are persecuted, and the slanderous charge of cowardice is a charge made not against Athanasius but against the divine logos himself. Episcopal flight is once again confirmed as an act of filial allegiance to those saintly men who have come (and gone) before him and, more importantly, to the Son who affirms his role as an authentic witness to the truth.

By way of contrast, Athanasius stresses that the Arians disinherit themselves from this past of persecution. They are worthy of blame because they conspire and collude with the empire: "For the Arians were mixed with the soldiers in order to exasperate them against me" (Athanasius, Fug. 24). The Arians not only mimic the past of imperial persecution but also take a leading role as the new persecutors of the faith.

Despite these criticisms of imperial mimicry, Athanasius does not wholly discount the language of civic authority. Athanasius easily transitions from being disciplined to being a disciplinarian. He appropriates a political rhetoric that corresponds with the very same violence of empire that his adversaries appear so eagerly to abuse. ${ }^{38}$ In so doing, he redefines the ecclesiastical office in terms of civic leadership. The new alliance between civic and ecclesial authority speaks to the very divisive performance of the bishop in the text, first evident in his displacement of the authority of the martyrs. The complicit relationship with empire is clearly an ambivalent one: Athanasius both profits and suffers under its recognition. Consequently, he is split between what Rebecca Lyman characterizes as "the old ideals of a separate Christian identity and the new social realities of a public, imperial church." ${ }^{39}$

37. Ernest, Bible in Athanasius of Alexandria.

38. For a more recent discussion on the role of violence in Christian polemic, see Thomas Sizgorich, Violence and Belief in Late Antiquity: Militant Devotion in Christianity and Islam (Philadelphia: University of Pennsylvania Press, 2008), esp. 12-18 and chapter 4, for an examination of fourth-century explorations of Christian religious violence.

39. Rebecca Lyman, Christology and Cosmology: Models of Divine Activity in Origen, Eusebius, and Athanasius (Oxford: Clarendon, 1993), 126. 
Athanasius thus emphasizes filial piety in order to lay claim to the authority of orthodoxy. The orthodox subject displays an image of the appropriate relationship between Father and Son. The heretic, however, mocks this heavenly relationship by acting impiously. The distinction clearly has both a theological and a political function. David Brakke points to Athanasius's use of the term politeia in order to articulate how the bishop distinguishes the pious from the impious. Those who correctly imitate the saints bear the image (eikonn) in their way of life (politeia).40 Athanasius, as an imitator of the saints in flight, bears the image of those saints who have gone before him: "For since the manner of our withdrawal [tēs anachōrēseōs] was such as we have described, I do not think that any blame whatever can attach to it in the minds of those who are possessed of a sound judgment: seeing that according to holy scripture, this pattern has been left us by the saints for our instruction" (Athanasius, Fug. 26.8, emphasis mine).

Athanasius once again affirms that the saints, in their imitation of the Son's flight, model themselves after his image. They are, therefore, correct to imitate the heavenly civic life on earth and, more importantly, in the desert. It is in this moment that Athanasius equates flight with an ascetic withdrawal. Brakke also notes how Athanasius plays upon the ambiguous nature of the Greek verb anachōrein, "to withdraw." He uses the term to present his flight, and the flight of those before him, as an ascetic practice. ${ }^{41}$ The imitation of flight is, again, both a theological and a political act. It unites the true Christians with the heavenly politeia now realized in the desert.

In Defense of His Flight, it is the Arians who mimic imperial persecution. They persecute the saintly fathers, making a mockery of their true alliance. Athanasius is careful here to blame the heretics and not the empire for his flight, even when Constantius, the emperor most known for his Arian sympathies, is rhetorically set up as the dupe of Arian impiety: "He compelled then the people in every city to change their party; ... he proceeded to act entirely in accordance with the designs and suggestions of the heretics; or rather they acted themselves, and receiving authority from him, furiously attacked everyone" (Athanasius, H. Ar. 30-31). Their impiety (asebeia) exposes their abuse of civic authority and eventually undermines their claim to the identity Christian. Yet, as Burrus and Daniel Boyarin point out, Athanasius is "reduced to mimicking the very mockery he attributes to the Arians, his own strident claims to authority are both exposed and subtly destabilized

40. "This ethic of imitation exploited the double meaning of the terms politeia ('civic life'), which referred both to an individual citizen's behavior and to a city's shared life and institutions: individual imitation of a saint's politeia contributed to the formation of the Church's politeia" (Brakke, Athanasius and Asceticism, 164).

41. Athanasius, Fug. 6.22; 10.20; 12.12; 13.14; 19.5; 20.24; 24.6, 23, 27, 28; 26.5; and Brakke, Athanasius and Asceticism, 106n123. 
by their very excessiveness." ${ }^{22}$ The space of authority thus functions discursively within Athanasius's account of personal suffering in exile.

Yet Athanasius must project his own mimicry of empire back upon his oppressors by inhabiting the rhetorical space of both a civic and an episcopal leader. On the one hand, the dishonor supports Athanasius's textual claim that persecution "is a device of the devil" (Athanasius, Fug. 23.8). Those who persecute conspire with their father, the devil, and make a mockery out of the commandment to honor your father and your mother. On the other hand, Athanasius does not hesitate to occupy the position of despot when force is necessary: "He who curses his father or his motherlet him die the death" (Athanasius, Fug. 2.9, emphasis mine). The strategic splitting of imperial discourse results in a discursive doubling: Athanasius condemns the Arians, just as they condemn him in order to preserve the integrity of civic authority. His use of piety, moreover, projects his own despotic language back onto the Arians while claiming absolute power to cast judgment on them: "But there is a common blot that attaches to them, in that through their heresy, they are enemies of Christ and are no longer called Christians, but Arians" (Athanasius, Fug. 27.2).

Athanasius capitalizes on this new identity of civic and ecclesial authority in the most unlikely of figures: a desert monk. Antony functions for Athanasius as a mirrored spiritual ruler of the new city, the exiled politeia of the desert. This unlikely hero creates a heterotopic vision of a new city in the desert where the truth now resides. It is in his vita that Athanasius once again reconfigures himself in the desert landscape in the guise of another withdrawing saint.

\section{A MODEL CITY WITHOUT WALLS: LIFE OF ANTONY}

It is the geographical periphery that allows Athanasius to establish his own authority as the author of one of the most famous stories of flight into the desert. The Life of Antony is one way in which Athanasius authorizes himself through the genre of (auto)biography and therefore sets up a particular definition of orthodoxy that will be repeated in both the Greek East and the Latin West. By telling the story of the saintly monk who flees into the desert, Athanasius not only legitimizes the desert space which he now inhabits but also establishes the literary paradigm for how he imagines his own exile: as a desert askesis.

The Life of Antony traces the life and movements of the famous monk Antony, who abandons the life of the polis for the desert. His strict practices serve as a model for ascetic discipline and exemplary Christian life. The biography was vastly popular and by the fifth century had been translated into many languages. ${ }^{43}$ For our

42. Daniel Boyarin and Virginia Burrus, "Hybridity as Subversion of Orthodoxy? Jews and Christians in Late Antiquity," Social Compass 52 (2005): 435.

43. For a detailed analysis of the afterlife of the Life of Antony and its many translations, see Vivian and Athanassakis, Athanasius of Alexandria. 
purposes, it is worth stressing that Athanasius composed this text during his time in the desert in $357^{44}$ The basic structure of the text includes a description of Antony's early life, a detailed account of his discipline (askesis), and a narration of his death.

It is now generally accepted that Athanasius's soteriology is worked out in this tale of the life of the fleeing monk. ${ }^{45}$ As is clear in Athanasius's first work, On the Incarnation, the first human beings were created out of nothing (ex nihilo). ${ }^{6}$ Athanasius's soteriological claims are tangibly embodied in the very genetic makeup of humanity. With the introduction of sin, humanity is condemned to a life of dissolution, both in body and in mind. Athanasius states: "Transgression of the commandment was turning them back to their natural state, so that just as they have had their beginning out of nothing, so also, as might be expected, they might look for corruption into nothing in the course of time" (Athanasius, Inc. 4.4). In the Life of Antony, Athanasius works this theological understanding of the state of humanity and its salvation into the very movements of the monk. Antony flees further and further into the desert to rediscover and renew the primordial state of humanity.

As Dag Øistein Endsjø notes, the Greek understanding of the original human is found in border areas, such as the eschatia. ${ }^{47}$ Although the term eschatia is absent from Athanasius's Life of Anthony, Endsjø makes a strong argument for why it is

44. Some scholars still debate the authorship of this text, which was first questioned by H. Weingarten, "Der Ursprung des Mönchtums im nachconstantinischen Zeitalter, Zeitschrift für Kirchengeschichte 1 (1877): 11-35. Weingarten argues that Athanasius could not have been its author and that Christian asceticism began well after Antony's death. The transmission and translation has also caused some scholars to question Athanasius's involvement in the composition of the Greek life. Other scholars have questioned why Antony seemed to be all but absent in Athanasius's other works. While these are certainly good questions to ask, I nevertheless follow the convention that this text was written by Athanasius. In addition to other scholarly arguments, the thematic links highlighted in the two other texts explored in this chapter prove to be too compelling for this reader.

45. Robert C. Gregg, Athanasius: Life of Antony and Letter to Marcellus (Mahwah, NJ: Paulist, 1977), xiii-xxi.

46. For a more developed argument concerning the intersection between Athanasius's soteriology and cosmology, see Lyman, Christology and Cosmology, esp. 124-59, and Burrus, Begotten, Not Made, $40-58$.

47. See Dag Øistein Endsjø, Primordial Landscapes, Incorruptible Bodies: Desert Asceticism and the Christian Appropriation of Greek Ideas on Geography, Bodies, and Immortality (New York: Lang, 2008). Endsjø insists that Athanasius is working within a Greek tradition of biography. His intervention counters an unproblematized assumption too often made by Athanasian scholars that the bishop was not classically educated or knew little of traditional Greek paideia. Endsjø repeatedly points out that Athanasius was well within the bounds of a Greek worldview and used a common language and structure in his writings, especially in his use of the biography genre: "The very structure of the hagiography reveals the author's familiarity with the classical genre of biography ... the description of Vita Antonii 14.3-4 is clearly modeled on a section of Porphyry's Vita Pythagorae" (ibid., 28). Athanasius, contrary the claims he makes about himself, was an educated bishop familiar not only with literary genres such as biography but also with the rules of argument and rhetoric, as we saw in the previous exploration of his apologies. 
useful here. He describes the concept of eschatia as a shared literary understanding of those borderlands that serve to constitute the polis. Eremos, "desert," the term favored by Athanasius, describes the desert as an uncultivated and untamed wilderness outside of Egypt proper. Athanasius uses this term interchangeably with oros, "mountain." Due to the loose way in which Athanasius deploys these terms, as we saw in his Defense before Constantius, Endsjø rightly argues that Athanasius is, for the most part, invoking the broader concept of the eschatia used by other Christian writers (such as Gregory of Nazianzus, whom we will discuss in further detail in the next chapter) to describe the desert. The eschatia is that area outside of the polis, where the human and the divine meet. It is also where the two intermingle. This conception of desert thus expands its meaning and function for Athanasius and allows the desert to take on a new life as a literary theme, as the monk journeys into the desert and away from the city walls. This familiar Greek worldview distinguishes between polis and borderlands by introducing physical borders as well as temporal ones.

The Greek city exists in the present tense, whereas the eschatia-as a place where the proper polis has never been established and the land has never been properly cultivated-forever reflects the past. This was how any part of the Greek periphery could be considered to reflect something like an eternal continuation of a primordial golden age. By deserting the city for the wilderness, one not only left civilization behind; one turned back time. Take away the city, and not only is the essence of humanity removed, but even the aspect of present time..$^{48}$ As Antony ventures further into the desert, for example, he quite literally stops the movements of his biological clock. His body is suspended in time as he embodies the very place in which he resides.

In the early part of his askesis, Antony flees merely to the catacombs outside of the city (Athanasius, Vit. Ant. 8). After he conquers this challenge, he goes further into the mountains and takes up residence in an abandoned fortress (Athanasius, Vit. Ant. 12). In a particularly revealing passage, witnesses are amazed at the sight of Antony's body. As he ascends out of the deserted fortress in the desert, they are shocked to find that "his body had maintained its former condition, neither fat from lack of exercise, nor emaciated from fasting and combat with demons, but was just as they had known him prior to his withdrawal" (Athanasius, Vit. Ant. 14). At the height of his withdrawal, Antony moves from the outer and to the inner desert, which is a noman's-land (Athanasius, Vit. Ant. 49). This final phase of his ascetic retreat into the desert ensures that Antony's body neither suffers from mortal decay nor is changed by age. Even at the point of death his body is miraculously well preserved.

He never succumbed due to old age, to extravagance in food, nor did he change his mode of dress because of frailty of the body, nor even bathe his feet with water, and 
yet in every way he remained free of injury. For he possessed eyes undimmed and sound, and he saw clearly. He lost none of his teeth-they simply had been worn to the gums because of the old man's great age. He also retained health in his feet and hands, and generally he seemed brighter and of more energetic strength than those who make use of baths and a variety of foods and clothing. (Athanasius, Vit. Ant. 93)

Here we see Athanasius's soteriological claims being worked out in Antony's body. Due to his strict discipline and Christlike appearance, his body is perfected. It has begun to take on the likenesses of immortality rather than of dissolution. Embodiment is intimately linked to landscape.

James Goehring has argued that the desert functions for Athanasius as a Greek landscape steeped within a literary imagination of the Graeco-Roman culture. ${ }^{49}$ The desert functions as a rhetorical tool that subverts civic ideologies. Goehring remarks, "Antony flees to the desert because truth resides in the desert." ${ }^{50}$ Antony thus sets up a dichotomy that sees the polis as a place of corruption over against the desert, which allows the monk access to truth. Yet the desert is not just where truth naturally resides. The inhabitant of this abstract desert landscape must also embody truth in order for truth to inhabit the space. According to Athanasius, it is Antony, not just any monk, who flees into the desert. And it is this monk alone who brings the truth with him. Antony is certainly the hero of the text, and his death appears to be the end of the story-or at the very least the natural consequence of the human condition. Yet there is another incarnation of truth in the text, one that has been with the reader for the entirety of the monk's life.

Athanasius self-consciously bookends the monk's tale, inserting himself into the text in the prologue and surfacing yet again on the lips of Antony as he dies. We learn in those last moments that it is Athanasius who clothed the monk. And on his death bed, Antony commands his followers to return his tattered clothing to Athanasius: "To Bishop Athanasius give the one sheepskin and the cloak on which I lie, which he gave to me new, but I have by now worn out" (Athanasius, Vit. Ant. 90). ${ }^{51}$ The reader is reminded that the monk has been clothed in the bishop's mantel for the entirety of his journey into the desert, a detail that does not escape the notice of Jerome, who records that the ascetic monk requests to be buried in Athanasius's cloak (Jerome, Vit. Paul. 12). As the monk disrobes himself at the point of death, it is the bishop who is exposed. Burrus vividly points out that it is Athanasius who is the "exile sometimes seen lurking within city limits with the

49. James Goehring, "The Dark Side of the Landscape: Ideology and Power in the Christian Myth of the Desert," Journal of Medieval and Early Modern Studies 33, no. 3 (2003): 437-51.

50. James Goehring, "The Encroaching Desert: Literary Production and Ascetic Space in Early Christian Egypt," Journal of Early Christian Studies 1, no. 3 (1993): 284.

51. We might also read a passage found in the middle of the text as another reference to this cloak: "He subjects himself to an even greater and more strenuous asceticism, for he was always fasting, and he had clothing with hair on the interior and skin on the exterior that he kept until he died" (Athanasius, Vit. Ant. 47). 
unworldly scent of the desert on his ragged sheepskin cloak." ${ }^{2}$ While we know how the monk's story ends, the pungent mantle of authority lives on in the literary fabric of the exiled bishop who also now finds himself in the desert-turned-city.

Brakke asserts that the Life of Antony epitomizes Athanasius's ascetic program, ${ }^{53}$ and I argue that it also legitimizes his exile. What Athanasius will come to call a "withdrawal" (anachōrēsis) into the desert does important work for the bishop. In a letter to fellow bishop Dracontius, he differentiates between two types of withdrawal: "The surprising unanimity about your election in the district of Alexandria will necessarily give way to schism because of your withdrawal [anachōrēsis], and the episcopate of the district will be grasped at by many.... Think of the Church, lest because of you many of the little ones be harmed and the others receive a pretext for withdrawing [anachōrēsis]" (Athanasius, Ep. Drac. 1.3).54 Monks withdraw in order to dedicate their lives to discipline and to seek out an individual path to the contemplative life. Bishops are also permitted to withdraw, but they must take extra care. Their lives are much more demanding. The monk has to care only for himself, but the bishop must recognize that he lives for the good of his flock. ${ }^{55}$ Brakke states: "Athanasius argued that the moral discernment that must accompany ascetic withdrawal should take into account the welfare of the Church, full of 'little ones' and endangered by people who are 'crooked', because the Church and its episcopate were essential to the monastic life. There would be no monks, Athanasius tells Dracontius, without the church and its bishops. ${ }^{56}$ Athanasius's own withdrawal into the desert, then, is interpreted as a benefit for the desert ascetic community. But his ascetic withdrawal must only ever be temporary. Ultimately, his flight into the desert is reimagined as a temporary ascetic retreat into a heterotopia.

I refer here to Michel Foucault's notion of heterotopic spaces to elucidate Athanasius's theory of the desert because Foucault helpfully captures how alternate spaces or other spaces reflect back to us certain ideals. A heterotopia-such as a garden, a prison, or a museum-acts as a mirror between built space and the human imaginative space around which it is constructed:

In the mirror, I see myself there where I am not, a sort of shadow that gives my own visibility to myself, that enables me to see myself there where I am absent: such is the utopia of the mirror. But it is also a heterotopia in so far as the mirror does exist

52. Burrus, Begotten, Not Made, 38 .

53. Brakke, Athanasius and Asceticism.

54. Edition: PG 25. Translation mine unless otherwise noted.

55. This work is an intellectual biography of Athanasius as well as a thorough history of asceticism in the fourth century, as noted by Brakke, Athanasius and Asceticism.

56. Brakke, Athanasius and Asceticism, 106. Athanasius argues that there would be no Christians without bishops: "For if everyone were of the same mind as your advisers now are, how would you have become a Christian since there would be no bishops? And if those who come after us receive this state of mind, how will the Church be able to hold together?" (Athanasius, Ep. Drac. 2, trans. Brakke, Athanasius and Asceticism, 99-101). 
in reality, where it exerts a sort of counteraction on the position that I occupy. From the standpoint of the mirror I discover my absence from the place where I am since I see myself over there. Starting from this gaze that is, as it were, directed toward me, from the ground of this virtual space that is on the other side of the glass, I come back toward myself; I begin again to direct my eyes toward myself and to reconstitute myself where I am. ${ }^{57}$

Foucault holds that the ideals of societies are found in the heterotopic places. These spaces both reflect the space a person occupies and hold the image of a space from which a person is absent. The function of a heterotopia is to create a space of illusion or a space that is other-a perfected space of compensation. Athanasius's use of desert is compensatory in just this fashion. The desert is infused with multiple meanings that allow Athanasius to reconstitute his displacement as a relocation into a counterspace full of generative possibilities. The desert is remade into an alternate city that reflects the one from which he is so frequently absent.

A heterotopia reflects both a specific location, that place at which a person is not, and the myth of a location, that space in which a person sees himself or herself. As we have explored, Athanasius's use of the desert counteracts the space that the bishop in flight actually occupies during his exile. The role of the heterotopia, according to Foucault, "is to create a space that is other, another real space, as perfect, as meticulous, as well arranged as ours is messy, ill constructed, and jumbled." ${ }^{8}$ The desert becomes the city that Alexandria could not be.

\section{CONCLUSION}

The myth of the desert functions for Athanasius as this counterspace to which he has been banished. ${ }^{59}$ The desert transforms into a heterotopia as the bishop, as monk, moves deeper into it. As Athanasius seeks to escape the polis, the polis is paradoxically recreated in the desert. This is evident when Athanasius remarks that Antony's popularity and devoted imitators grew so large that the "desert was made a city" (Vit. Ant. 14). The politeia is not only the location of civilization, but it is also, for Athanasius (by way of Antony), a shared way of life. That shared way of life is not found in Alexandria proper but is reflected in the heterotopic city of the desert.

As Antony draws deeper into the desert, and into the truth, his entire being is transformed. This withdrawal and transformation not only supports Brakke's observation that this text successfully synthesizes Athanasius's ascetic program, but it also supports Athanasius's larger project-namely, reconfiguring his exile as desert askesis, which authenticates his claim to orthodoxy. The remaking of the

57. Michel Foucault, "Of Other Spaces," Diacritics 16, no. 1 (1986): 24.

58. Ibid., 27 .

59. Goehring, "Dark Side of the Landscape," 437-51. 
desert into a new politeia, as we saw in the Defense of His Flight, allows Athanasius to reimagine this heterotopic space as a counterspace, a countercity.

To state it another way, the remaking of the desert into a new politeia provides an alternative vision to the corruption rampant in the neighboring city. This desert turned city is notably free of heresy and walls. The rhetoric of political legitimacy requires that the vision of an ideal politeia be removed from the confines of heretical influence. ${ }^{60}$ Alexandria is, as Burrus remarks, "a city that traces a horizontal path of transcendence into the desert, where it is reconceived as a harmonious community of fathers, sons, and brothers, overseen by the orthodox bishop, to whom Father Antony himself had bequeathed one sheepskin and the garment that Athanasius had given him long before." ${ }^{11}$

Athanasius thus capitalizes on ascetic Christianity as a way to legitimize his own position as an exile. As we will soon see, Gregory of Nazianzus's own (auto) biographical reflections will draw a similar conclusion. In the next chapter, I will show how Gregory uses Athanasius's desert exile qua askesis as a way to amplify the Alexandrian bishop's own success as an orthodox figure in the desert. Gregory's In Praise of Athanasius, however-like Athanasius's reflection on his return to Alexandria in his History of the Arians - must retrieve the exiled bishop from the desert. It seems that Athanasius does not live on in a heterotopic desert but returns and lives on firmly seated within the walls of the city. The desert is once again reread as an alternate space, but for Gregory, it is only a temporary residence. The civic centers of the empire, and the walls and the doors of its churches, are where true orthodoxy must be found.

6o. Cicero makes a similar move when he describes the res publica as being in exile alongside of Marcus Claudius Marcellus after the Pompeian revolution and Caesar's occupation of Rome; see Cohen, “Cicero's Roman Exile." Cicero concludes, much like Athanasius will later, that one's exile is not dependent upon a physical location.

61. Burrus, Begotten, Not Made, 76; she has in mind here Athanasius, Vit. Ant. 91. 


\section{How to Return from Flight}

I withdrew temporarily until I had [time to] reflect and console my grief, but now I am commissioned to exalt him among the people of the church and the seat of the presbyters. If the temporary withdrawal deserved blame, this worthy return pardons [it].

—GREGORY OF NAZIANZUS, DEFENSE OF HIS FLIGHT

The wildness of the desert landscape held theological and cultural significance within Christian memory well before and after Athanasius of Alexandria fashioned his city in the Nitrian desert. Within the Christian imagination, the desert was the ultimate training ground for Christian fortitude. Like Athanasius, other early Christian writers would capitalize on the theological as well as culturally significant space of the desert to imagine and reconstruct their heroes of the past. These men and women of faith were not simply tested in the desert during peak periods of persecution. They also had to find the courage to return. For someone like Gregory of Nazianzus, Christian flight always carried with it uncertain dangers. The charge of cowardice, which we have addressed before, was always a step or two behind the fleeing saint. These flights into the wild, therefore, could not be an end in themselves. True Christians must carry the knowledge of their desert sojourn with them back to the city. According to Gregory, it is only after one returns that the full benefits of Christian flight are realized and, more importantly, justified. As we will come to see, Gregory's legacy as a man in flight is dependent upon this logic.

In this chapter, we will explore how Gregory's biographical depictions of both Basil of Caesarea and Athanasius of Alexandria as fleeing men were paramount to his theological offensive in and around Constantinople. We will begin by examining how Basil's familial link to other fleeing men and women and then his own flight to Pontus helped secure his victory over heresy. Then we will turn to how Gregory promoted Athanasius's exile into the desert. As Gregory narrated

1. Gregory of Nazianzus, Orat. 2.115. Edition: SC 247. Translation in consultation with PG 35:58-59, 513 and NPNF2 7, with modifications. 
it, orthodoxy is intimately tied to ascetic withdrawal. Ultimately, both Basil and Athanasius must return to their respective cities, for it is their return that confirms their authority. And-as he concludes in defense of his own flight-the return is what pardons the flight.

\section{HOW TO REHABILITATE A FAILED BISHOP: GREGORY OF NAZIANZUS}

Gregory of Nazianzus was born around 329, the middle child of three. His elder sister, Gorgonia, and his younger brother, Caesarius, played an integral role in Gregory's autobiographical reflections, as did his influential parents, Gregory the Elder and his beloved mother, Nonna. As a highly educated man, Gregory reflects the best of what late antiquity had to offer. His studies took him to the epicenters of Graeco-Roman education: Caesarea, Caesarea Maritima (Palestine), Alexandria, and Athens. It was in these influential cities that he developed as a rhetor and fierce intellectual.

Gregory's education was not without its controversy, however. As Neil McLynn and Susanna Elm have both argued, it was at Caesarea Maritima that Gregory and his friend Basil may have first encountered (however briefly) Origen of Alexandria's works and possibly purchased a copy of the Philocalia. ${ }^{2}$ Origen's ideas and legacy would later haunt Gregory, among others, in powerful ways. ${ }^{3}$ Nevertheless, Gregory was a man of the city and his greatest works were written and influenced by all it had to offer.

Gregory was as well connected as he was well traveled. He seemed to collect famous friends as he did controversial texts. While studying in Athens, Gregory met Basil, the future bishop of Caesarea. ${ }^{4}$ According to Gregory, the two became inseparable and continued to influence one another throughout their literary and ecclesiastical careers. ${ }^{5}$ And it was Basil's brother, Gregory of Nyssa, who

2. For detailed assessment of the scholarly discussion on Gregory and the Philocalia, see Susanna Elm, Sons of Hellenism, Fathers of the Church: Emperor Julian, Gregory of Nazianzus, and the Vision of Rome (Berkeley: University of California Press, 2012), nn. 22-23, 34. Mark DelCogliano has recently challenged this claim in his "Tradition and Polemic in Basil of Caesarea's Homily on the Theophany," Vigiliae Christianae 66 (2012): 54. DelCogliano's article provoked a response from Adam Rasmussen, "Basil of Caesarea's Uses of Origen in His Polemic against Astrology," Zeitschrift für Antikes Christentum 18, no. 3 (2014): 472. The encounters of both Gregory and Basil with Origen's teachings are found in Sozomen, Eccl. Hist. 6.17.

3. See chapter 4 for a discussion on the Origenist controversy and its influences on John Chrysostom's biographers and many other figures who traveled between Alexandria and Constantinople. Sozomen's easy acceptance of Origen's influence is also quite telling once we examine the history of the Constantinopolitan see in his ecclesiastical history.

4. Not to be confused with the so-called homoiousian bishop of Ancyra.

5. Neil McLynn has called into question just how close Basil and Gregory actually were. See McLynn, “Gregory Nazianzen's Basil: The Literary Construction of a Christian Friendship," Studia Patristica 37 (2001): 178-93. 
would eventually complete their triad as the Cappadocian fathers. Their friendship-and a rapidly growing social network of pro-Nicene heavy hitters-was remembered as what fiercely defended Asia Minor against the throes of heresy. It was no coincidence, according the later ecclesiastical historians, that the epic battle over Nicene Christianity came to a head in the eastern capital of the Roman Empire, Constantinople.

Gregory's extensive literary corpus frequently alludes to the support provided by influential friends in the surrounding powerful cities of Asia Minor. While at times hard to retrace, his biographical works provide us with a glimpse into the complex theological battles that were waged on the road from Nicaea to Constantinople. It is unsurprising, then, that this elite man from the small town of Nazianzus quickly rose through the ranks, even to briefly take over the coveted role as bishop of Constantinople. His influence and connections continued to bolster his reputation. Even after his failed and brief tenure in Constantinople, his notoriety would continue to follow him and eventually win him the name "Gregory the Theologian."

As a gifted rhetorician, he made full use of his talents to laud the achievements of his friends as well as his theological allies. His use of panegyric, for example, has been well documented and will occupy our attention later in this chapter. But before we turn to his impressive display of oratorical skill, we must first examine his journey to Constantinople and why it was possible for this particular man not only to inherit this powerful episcopal seat but also to help establish a formidable brand of Nicene Christianity firmly within its walls.

Much like Alexandria, the city of Constantinople occupies an important place within Christian memory, particularly in the ecclesiastical histories of the fifth century. And, as we found in the previous chapter, the locations and the borders of orthodox spaces are infused with cultural and theological meaning in the growing battle over Nicaea. Here we will begin to explore how Gregory of Nazianzus played an important role in constructing the Constantinopolitan legacy as a pro-Nicene one that later historians would look to as their guide. This process was due in no small part to Gregory's links to Athanasius and his exilic discourse. His claim over the Alexandrian legacy, however, would not go unchallenged.

As we will come to see, Gregory, either keen to take a risk or pressured into the position, made ample use of other theologically-infused spaces to shore up Constantinople's orthodox reputation, as well as his own. ${ }^{6}$ As Elm has recently

6. The naming of Constantinople as a "New" or "Second" Rome is contested prior to 381. It is commonly accepted that the title is confirmed at the Council of Constantinople. Lucy Grig and Gavin Kelly also reference Themistius, who, in a speech before Constantius II in 357, claims that Rome and Constantinople "share their Fortune (tychē) and name, the old and the New Rome (Or. 3.42a, 42c)." See Grig and Kelly, "From Rome to Constantinople," in Two Romes: Rome and Constantinople in Late Antiquity, ed. Lucy Grig and Gavin Kelly (Oxford: Oxford University Press, 2010) 11. They also cite Socrates, Eccl. Hist. 1.16.1; CTh 13.5.7, 1; and a poem by Publilius Optatianus Porphyrius Carmina 4.6. See also Grig and Kelly, "From Rome to Constantinople," 11n39, for debates concerning earlier references. 
noted, the urban competitions taking place in Constantinople, Alexandria, and Antioch-and, I would add, Nicomedia-are instructive as we assess the growing significance and overlap of imperial and theological import in the aftermath of the council of Nicaea. ${ }^{7}$ Unfortunately, most of our evidence comes from later historians. We will return to the historiographical exercise of the later pro-Nicene historians at a later point. For now, we will concentrate on the various ways the city of Constantinople and its embattled episcopacy took on new levels of theological and political significance in a very short period of time.

\section{HOW TO CONSTRUCT A MODEL CITY: CONSTANTINOPLE}

Constantinople's rapidly growing wealth and size made the city an ecclesiastical force in the Roman Empire during the late fourth and fifth centuries. ${ }^{8}$ The city, given its name by Constantine, was founded in $324 \mathrm{CE}$ and dedicated by the emperor on May 11, 330. And while it was never the primary residence of Constantine-he appeared to favor the neighboring city of Nicomedia-it grew significantly until his death in $337 .{ }^{9}$ Soon after that, its population expanded dramatically, and the city was adorned with art installations and statues imported from across the empire. ${ }^{10}$ Constantinople was soon regarded as the seat of emperors-Julian was the first to be born there-although it was not consistently inhabited by imperial rulers until Theodosius in $380 .{ }^{11}$ However, Constantius II is said to have brought the relics of Timothy, Luke, and Andrew to the city in 356-357, and the bones of Constantine were said to have been transferred to Constantinople shortly after his death. ${ }^{12}$ Finally, church buildings were commissioned during this period, which culminated in construction of the basilica of Hagia Sophia, which transformed Constantinople into a holy city in its own right.

7. Elm, Sons of Hellenism.

8. For a helpful material reconstruction of the city grid enabled by a close examination of the layout of the streets, see Albrecht Berger, "Streets and Public Places in Constantinople," Dumbarton Oaks Papers 54 (2000): 161-72.

9. For a description of the building campaign, see Hartmut Leppin, Theodosius der Große: Aufdem Weg zum christlichen Imperium (Darmstadt: Primus, 2003), 188-201.

10. For material evidence, see Carlos Machado, "Aristocratic Houses and the Making of Late Antique Rome and Constantinople," in Two Romes: Rome and Constantinople in Late Antiquity, ed. Lucy Grig and Gavin Kelly (Oxford: Oxford University Press, 2012), 136-58. Machado explores the urban development of both Rome and Constantinople and provides useful biographical references in his footnotes, as well as helpful maps of aristocratic domiciles. For references to Constantinople, see especially $154-58$.

11. Brian Croke, "Reinventing Constantinople: Theodosius I's Imprint on the Imperial City," in From the Tetrarchs to the Theodosians: Later Roman History and Culture, 284-450, ed. Scott McGill, Cristiana Sogno, and Edward Watts, Yale Classical Studies 34 (Cambridge: Cambridge University Press, 2010), 241-42.

12. We will explore this detail in chapter 5 . 
The overlap of imperial fanfare with Christian ritual has been extensively studied. Lucy Grig and Gavin Kelly have pointed out that Constantinople's history as the chosen capital of Constantine symbolized the triumph of Christianity, imagined or real, and placed it on equal footing with Rome. ${ }^{13}$ The Nicene legacy instilled by Theodosius I marked the city as theologically significant, and it continued to thrive well beyond that emperor's death in $395 .{ }^{14}$ Whether or not Constantinople even stood as a competitor, let alone a usurper, of Rome's powerful influence is certainly debatable. But it is clear that Constantinople's champions certainly believed it to be a political and ecclesial contender among the surrounding imperial cities of the Eastern Roman Empire. More importantly, the power its bishop held was not to be overlooked. Indeed, by the late fourth century, Constantinople stood as a strong rival not just to Rome but also to Alexandria in terms of its theological and political significance within Asia Minor. This ongoing race for theological influence would be a source of woe for Gregory and those who followed in his footsteps. ${ }^{15}$

Before his appointment to Constantinople, Gregory was given the bishopric of Sasima, although he never actually appears to have taken up his charge there. Instead, he spent a short period tending to his ailing parents in Nazianzus; after their deaths, he fled to Seleucia for three years. ${ }^{16}$ By this point in his life, he was already well known as a man in flight and extremely hard to pin down. As Bradley Storin has argued, many of Gregory's acquaintances in and around Asia Minor persuaded him to take up residence in Constantinople. ${ }^{17}$ Members of the Antiochene council in 379 would help to position him as the favored pro-Nicene representative in the theological battleground. ${ }^{18}$ It is this role that would eventually lead to his election as its bishop.

According to the fifth-century historian Socrates, it was Theodosius I and not the Antiochene council who initiated his election as bishop of Constantinople,

13. Grig and Kelly, "From Rome to Constantinople," 14.

14. Constantinople's developing supremacy as the uncontested capital of the empire is hotly debated. Recently, scholars have tried to counteract persistent methods of research that take the vantage point of teleological interpretations espoused in monumental works such as Edward Gibbon's History of the Decline and Fall of the Roman Empire. They also seek to debunk mythic claims built around documents like the Donation of Constantine, a commonly acknowledged forgery. See, for example, Grig and Kelly, "From Rome to Constantinople," 3-30. Croke, "Reinventing Constantinople," 247, also draws out Theodosius's efforts to consolidate the various factions within Constantinople during his reign: "Faced with a plethora of church practice and belief that had produced a range of competing congregations centered on particular churches and a deeply factionalized community, Theodosius' instinct was to bring them all together and let them find their common ground."

15. See chapter 3 for a discussion of John Chrysostom's controversial election.

16. Gregory of Nazianzus, Carm. 2.1.2.547-51.

17. Bradley Storin, "The Letter Collection of Gregory of Nazianzus," in Late Antique Letter Collections: A Critical Introduction and Reference Guide, ed. Cristiana Sogno, Bradley K. Storin, and Edward J. Watts (Berkeley: University of California Press, 2017), 82.

18. Storin, "Letter Collection," 82, 96n12. 
only a few days after his own triumphant arrival. ${ }^{19}$ And Sozomen remarks that Theodosius gave the then bishop of Constantinople, Demophilus (frequently referred to as a homoian or simply an Arian), the opportunity to take up Nicaea's cause or leave. ${ }^{20}$ After informing his community of the edict, Demophilus encouraged his disciples to follow him outside the city walls. To make his reasoning perfectly clear, he invoked Matthew 10:23: "When they persecute you in one town, flee to the next." ${ }^{21}$ We will return to this verse at a later point. For the time being, regardless of who initiated Demophilus's replacement, Gregory never sat comfortably on the bishop's throne. ${ }^{22}$

To be fair, the story is further complicated by the series of rotating bishops prior to Gregory's ill-fated election to the see of Constantinople. The battle over the Constantinopolitan patriarchate was fierce from its earliest inception. ProNicene historians, for instance, will extol Alexander of Constantinople as the fiercest defender of Nicaea's legacy in the new Rome and claim him as its first official bishop. Socrates and Sozomen both state that it was Alexander alone who resisted Arius's readmittance into the church despite threats of banishment from Constantine. And, according to Athanasius, it was Alexander's prayers that brought about Arius's timely death right before his readmittance to the faith. ${ }^{23}$

But the race for control began soon after Alexander's death in 337. Rafal Kosinski has most recently provided a sketch of the subsequent power grab that took place. ${ }^{24}$ Between 337 and 339, Paul I and Macedonius I both vied for the position, with Paul as the favored candidate. In a curious move that will remain a sore spot in pro-Nicene memory, Eusebius of Nicomedia temporarily won the day (ca. 339-341). ${ }^{25}$ This detail is often downplayed by later historians or deemed a

19. Socrates, Eccl. Hist. 5.7. For Theodosius's calls for a unified Christianity, see CTh 16.1.2. For notes on whether Theodosius initiated a pro-Nicene position early on, see Elm, Sons of Hellenism, $403 n 93$. We will engage Socrates in more detail in chapter 5.

20. Sozomen, Eccl. Hist. 7.5.

21. Gregory's rival is also mentioned in Basil's letter, Ep. 48. Lester L. Field also believes Gregory takes a jab at Demophilus in his In Praise of Athanasius, when Gregory remarks, "For it is not the intruder, but he whose rights are intruded upon, who is the successor, not the lawbreaker, but the lawfully appointed, not the man of contrary opinions, but the man of the same faith; if this is not what we mean by successor, he succeeds in the same sense as disease to health, darkness to light, storm to calm, and frenzy to sound sense" (Gregory of Nazianzus, Orat. 21.8). See Field, On the Communion of the Damasus and Meletius: Fourth-Century Synodal Formulae in the Codex Veronensis LX (Ontario: Pontifical Institute of Mediaeval Studies, 2004), 159n88.

22. For a list of scholars who view Gregory's episcopacy as a failure, see Elm, Sons of Hellenism, $5 \mathrm{n} 15$.

23. Athanasius, Ep. mort. Ar. 4. Edition: Hans-Georg Opitz (ed.), Athanasius Werke II, Band 1, Erster Teil: Die Apologien (Lfg. 1-7) (Berlin: de Gruyter, 1940), 178-80.

24. For the most recent attempt to trace the many appointments and exiles of the Constantinopolitan bishops, see Rafal Kosinski, "The Exiled Bishops of Constantinople from the Fourth to the Late Sixth Century," Studia Ceranea 5 (2015): 231-47.

25. Kosinski helpfully traces the four exiles of Paul: 337, 341, 342-343, and 350-351; see Kosinski, "Exiled Bishops," 232n3. The episode of Macedonius's forced appointment is suspect given that the 
brief dark period within the history of the holy city, and it is one to which we will return. We might recall from the previous chapter that Eusebius appointed George of Cappadocia as Athanasius's replacement while he was firmly in control at Constantinople, with the full support of Constantius II. We hear of George's appointment in several of Athanasius's works, including the Defense before Constantius and Defense of His Flight. As David Gwynn has noted, both George and his successor, Gregory, are identified as "Eusebians" (hoi peri Eusebion) who are hirelings of the Arian party. ${ }^{26}$ It appeared as if the anti-Nicene party would win the day in both Alexandria and Constantinople, a point that Gregory contested in his oration, discussed below. Nevertheless, Eusebius's tenure as the bishop of Constantinople was a resounding success. Unlike Arius, Eusebius died unmolested and uncontested, a detail that remained embarrassing for later pro-Nicene historians.

Yet Eusebius was quickly replaced by Paul, a presumed pro-Nicene supporter, in what would later be described as a momentary reprieve. But Paul's grasp on the episcopacy, like that of Gregory later in his career, was a tenuous one. He was immediately ousted by the Arian-leaning Macedonius, whose seizure of the office was described as a riotous affair that resulted in a bloodbath. It took nothing short of an imperial escort to transfer Macedonius safely to the great Constantinopolitan Church. According to other pro-Nicene historians, an anti-Nicene stronghold remained in power until the triumphant arrival of Gregory of Nazianzus. ${ }^{27}$

Admittedly, this narrative is highly suspect, due to its pro-Nicene slant. What camp each bishop aligned himself with between the death of Alexander and the appointment of Eusebius of Nicomedia would certainly shift and change as new charges of heresy from all sides of the debate were hurled against each appointment. For our purposes, we should consider in hindsight how Constantinople was transformed into a beacon of orthodoxy once Gregory of Nazianzus, that defender

evidence we have comes from later pro-Nicene historians who are invested in preserving Paul as the true inheritor of the see and not his Arian counterpart.

26. David M. Gwynn, The Eusebians: The Polemic of Athanasius of Alexandria and the Construction of the "Arian Controversy" (Oxford: Oxford University Press, 2007), 54.

27. Macedonius was followed by Eudoxius in $360 \mathrm{CE}$, after Macedonius appears to have had a falling out with Constantius II (Socrates, Eccl. Hist. 2.38 and Sozomen, Eccl. Hist. 4.21). Evagrius briefly followed Eudoxius in 370 but was quickly replaced by Demophilus, although Evagrius appears to also have remained an active competitor. But with the arrival of the emperor Theodosius I, according to Sozomen, Demophilus fled the city along with his supporters and set up a church just beyond the city walls, a detail we will explore later. For recent works debating Demophilus's flight, see R. Malcolm Errington, "Church and State in the First Years of Theodosius I," Chiron 27 (1997): 21-72; Neil McLynn, "Moments of Truth: Gregory of Nazianzus and Theodosius I," in From the Tetrarchs to the Theodosians: Later Roman History and Culture, 284-45o CE, ed. Scott McGill, Cristiana Sogno, and Edward Watts, YCS 34 (Cambridge: Cambridge University Press, 2010), 215-39; and Susanna Elm, "Waiting for Theodosius, or the Ascetic and the City: Gregory of Nazianzus on Maximus the Philosopher," in Ascetic Culture: Essays in Honor of Philip Rousseau, ed. Blake Leyerle and Robin Darling Young (Notre Dame: University of Notre Dame Press, 2013), 185-86. 
of Nicene Christianity, took control. Much as it was for Athanasius, it is Gregory's own posturing and narration of the events that promoted this picture and made it the one later writers would adopt. It is worth emphasizing that only after the proNicene ecclesiastical historians picked up the storyline was Gregory's brief time in Constantinople remembered as a success. During Gregory's lifetime, however, this claim would be an embattled one.

Many of Gregory's problems appear to stem from his alliance with members at the Antiochene council, specifically his ties to Meletius of Antioch and his supporters. It is quite possible that the same group responsible for Gregory's appointment in Constantinople was also responsible for his inevitable flight. By aligning himself with Meletius rather than the Alexandrian favorite, Paulinus, Gregory placed himself at odds with Alexandria. I argue that this relationship was further strained by his insistence on claiming Athanasius's legacy upon his appointment to Constantinopolitan see. As Storin has recently pointed out, it was Timothy of Alexandria who first called into question Gregory's legitimacy as the rightful bishop of Constantinople, a connection we should not overlook and which I will make all the clearer in the next chapter. Timothy directly challenged Gregory's claim by invoking the fifteenth canon of Nicaea, "which prohibited the translation of bishops, priests, and deacons from one see to another." ${ }^{28}$ Although Gregory never took up his post in Sasima, it was an appointment he clearly could not escape. After a mere few months as the reigning bishop of Constantinople and president of the Council of Constantinople, Gregory was forced to step down and flee once again. For our purposes, it is the complex alliances forged between Alexandria, Antioch, and Constantinople (and Nicomedia) that continued to play a major role in the development of the Nicene legacy. Gregory is hardly the first to draw the attention and ire of Alexandria, and the outcome would soon become a familiar one.

Tension arose between Constantinople and Alexandria when Gregory claimed the Athanasian legacy and exilic discourse. In pro-Nicene memory, Gregory of Nazianzus is one of the first to shape Athanasius's story of exile as a sign of Christian orthodoxy, in his Oration 21, also known as In Praise of Athanasius, delivered in Constantinople in 380. ${ }^{29}$ Athanasius's theory of the desert and larger exilic discourse is revived and altered in this text and later championed by pro-Nicene ecclesiastical historians.

Gregory's adoption of Athanasius's exilic discourse in In Praise of Athanasius appears all the more significant when that text is read alongside his more famous panegyric, Oration 43, or In Praise of Basil the Great. In both works, we find remarkable links to the tradition of Christian flight and the heterotopic spaces of the desert.

28. Storin, "Letter Collection," 82. The account is found in Gregory of Nazianzus, Carm. 2.1.2.1810.

29. Gregory of Nazianzus, Orat. 21. Edition: PG 35:1081A-1128C and SC 270. Translations of this oration often modified slightly. 
As we will come to see, the mythical desert must eventually be left behind as both men return to their respective cities to secure their orthodox legacies. But before we turn to this text and its significance for later historians, we will examine Gregory's broader theory on Christian flight, because it is in the space between flight and episcopal duty that we find his most ardent defense of (his) orthodoxy.

\section{A MODEL EXILE: IN PRAISE OF BASIL THE GREAT}

From an early stage in his Christian journey, Gregory was a man in flight. The tugof-war between philosophical withdrawal and civic responsibility, captured in the epigraph with which this chapter began, would continue to haunt his many theological and, later, explicitly apologetic works. Gregory would eventually reread Christian flight as a temporary withdrawal in order to help preserve an orthodox reputation for himself as well as those with whom he associated. ${ }^{30}$ This rhetorical move is seen most clearly in his panegyrics on Basil of Caesarea and Athanasius of Alexandria. ${ }^{31}$

Basil of Caesarea, whose defense of Nicene politics in Asia Minor and ties to Alexandria played an important role in the pro-Nicene narrative read back into this particularly tense moment. Like Gregory, Basil's involvement with Antiochene politics would temporarily put him at odds with the pro-Athanasian narrative. As has been frequently noted, Basil was a firm supporter of two significant exiles, Eustathius of Antioch and Meletius of Antioch. This theological and political alliance temporarily called into question Basil's allegiance to Nicaea, due to questionable theological claims of those men. ${ }^{32}$

Between 330 and 415, in the aftermath of Eustathius's exile and the Council of Nicaea, Antioch would host anywhere from two to three competing bishops at a time, for reasons that are mixed and filled with intrigue. There appears to have been a split down geographic as well as theological party lines, as many vied for this bishopric. In Athanasius's On the Synod and Tome of Antioch we hear of significant, albeit failed, efforts to bring about a compromise among competing parties. For instance, Basil's stubborn support of Eustathius and, later, Meletius would put him at odds with the supporters of Paulinus, who aligned themselves with Alexandria. This ardent defense of the wrong party, according to Philip Rousseau, put Basil's orthodoxy on trial. On his way to meet Eustathius in 373 , for example, he

30. For Gregory's own efforts to rehabilitate his reputation in the period immediately after his failed tenure as bishop of Constantinople, see Bradley Storin, "In a Silent Way: Asceticism and Literature in the Rehabilitation of Gregory of Nazianzus," Journal of Early Christian Studies 19, no. 2 (2011): 225-57.

31. See, in particular, Elm, Sons of Hellenism, 213-24.

32. When we turn to the complicated history of John Chrysostom and his links to Antioch in the next chapter, we will continue to unravel the various ways in which the ties of Gregory and Basil to Antioch will eventually be reconciled and explained away. 
was asked to draft a statement of orthodoxy to clarify his theological position..$^{33}$ We will spend more time on the Antiochene divisions at a later point, but for now it is Basil's decision to support Meletius over against Paulinus that required a great deal of revisionary work by his most famous biographers, Gregory of Nyssa and Gregory of Nazianzus. ${ }^{34}$

There is a marked contrast between Gregory of Nyssa's Encomium on His Brother Basil (ca. 380-381) and Gregory of Nazianzus's In Praise of Basil the Great (Orat. 43) (382). In the former, the brother of the famed bishop of Caesarea is compared to the most exemplary biblical figures, chief among them the apostle Paul. As David Konstan highlights, this comparison eclipses his familial relationships. While Gregory of Nazianzus began with a narration of Basil's earthly attachments, as would be expected, Gregory of Nyssa lifted his brother out of his earthly lineage - and any possible scandals those links might bring about-and intentionally transplanted Basil into a biblical lineage in order to stress that he was a man from a different realm. ${ }^{35}$

Gregory of Nazianzus also stressed Basil's placelessness in his eulogy. But rather than strip him of his illustrious and elite lineage, Gregory instead emphasized his legacy as one among many fleeing saints, not unlike Athanasius's Defense of His Flight. ${ }^{36}$ Gregory appealed to Basil's familial heritage as a lineage filled with men and women who flee from the city into the wilderness to train and to learn that no earthly attachments, no homeland, and no creaturely comforts afforded by one's social status will effectively cultivate the virtues of a true Christian. Instead, the practice of ascetic withdrawal is what truly prepares the Christian for life's many trials. One does not stay in the desert, however; one must return to the city to do battle. Gregory of Nazianzus thus interprets Christian flight-here understood as a temporary ascetic retreat-as essential to one's training for the clerical office.

In his Oration 43, In Praise of Basil the Great, written a few years after Basil's death in 379, Gregory uses the theme of Christian flight to emphasize his dearly departed friend's virtue. ${ }^{37}$ What stands out in this speech is the way Gregory traces Basil's actions and reputation through his familial lineage to the men and women

33. Philip Rousseau, Basil of Caesarea (Berkeley: University of California Press, 1998), 241.

34. See chapter 6 on the effort to revive Meletius's legacy.

35. David Konstan stresses this placelessness: "His discourse constructs a barrier between Basil, who is written into a sacred text that is not so much ancient as transcendently enduring, and those outside the narrative space, whether the speaker himself or his audience who take Basil as their ideal. There is no communion between these realms: in saying nothing of Basil's family, Gregory is, of course, saying nothing of his own." See Konstan, "How to Praise a Friend," in Greek Biography and Panegyric in Late Antiquity, edited by Tomas Hagg (Berkeley: University of California Press, 2000), 165.

36. See chapter 1.

37. Gregory of Nazianzus, Funeral Oration to St. Basil (BHG 245-Oration 43); Critical ed. and French tr. Jean Bernardi, Gregoire de Nazianze, Discours 42-43, SC 384 (1992); Unless otherwise noted, English translation (with some slight modifications) follows Leo McCauley, Funeral Orations by Saint Gregory Nazianzen and Stain Ambrose, (FC 22) Washington DC, 1953, 27-99. 
who fled during times of persecution. Gregory looks back to their flight as what ushers in and secures Basil's heroism. He concludes that it was their willingness to flee that would model for Basil the virtue of, and even the demand for, Christian flight.

Notably, Gregory differentiates between Christian flight and imperial banishment. One is voluntary and the other compulsory. Imperial banishment, or the threat thereof, was a tool deployed by wayward emperors to compel bishops to bend to imperial rule and, as we saw with Athanasius in the previous chapter, served as a sign of Christian persecution. Gregory insisted that the true bishop does not fear banishment, because he will have already trained himself in the desert to prepare for his role as a Christian leader. Imperial threats of compulsory exile, then, have no hold on those bishops who have already wandered.

Gregory of Nazianzus's eulogy follows the standard formula for laudationes funebres. ${ }^{38}$ The first half of the speech praises Basil's ancestral lineage and describes his illustrious education. Then the text concludes with many details of his life, which continue to emphasize his virtue. What stands out in this eulogy, and is the focus of our study, is how Gregory characterizes exile as a desert askesis, which was also the conclusion of his earlier panegyric on Athanasius. We will begin with Gregory's eulogy on his friend Basil, although it is a later text than In Praise of Athanasius, in order to stress how the desert functions as a training ground for the Christian elite. We will then turn to his earlier oration on Athanasius to see how Gregory alters Athanasius's discourse to emphasize the temporary nature of Christian flight. It is this model that will set the standard for later biographical inheritors of Athanasius's legacy as an exile, and we will soon see why. While Athanasius's legacy as an orthodox exile during his own lifetime is linked to the language of persecution - a strategy Gregory will also use-the orthodox bishop ultimately must return triumphant to substantiate that claim. And he must return not to just any city, but to one bound to the legacy of Nicaea.

In his funerary speech on Basil the Great, Gregory states that it is possible to capture the value of a man in two ways: we can look to those traits inherited from a man's pedigree, and we can look to how that legacy influences the man's actions throughout his life. To begin, Gregory turns to the Christian persecutions under Maximinus (303-313). As we might expect, he stresses that martyrdom should be neither sought voluntarily nor avoided. It appears that Tertullian's charge of cowardice is never far behind. But the decision to flee is not an easy one, especially for the social elite. Gregory is careful to stress that when Basil's illustrious ancestors decided to escape, they chose the harder course. He describes their flight to the secluded location of Pontus in the following ways: "For their flight was exceedingly prolonged, to about seven years or a little more, and their mode of life, delicately nurtured as

38. For a description of the standard formula of a funeral oration, see Konstan, "How to Praise a Friend," 166-67. 
they were, was straitened and unusual, as may be imagined, with the discomfort of its exposure to frost and heat and rain. And the wilderness allowed no fellowship or converse with friends - a great trial to men accustomed to the attendance and honor of a numerous retinue" (Orat. 43.6). ${ }^{39}$ Here Gregory explains that those who were accustomed to the luxuries of life and constant companionship in their social circles were forced into far harsher conditions than the average Christian. These men and women were not used to living without the many comforts afforded to their class.

Gregory frequently compares their wandering to Israel's exodus. Without the comforts of Egypt, the Israelites also wandered with constant threat of starvation and exposure to the most abhorrent of living conditions. Like the Israelites, Basil's ancestors endured their sojourn into the wilderness in order to humble themselves and better prepare for their return. And because they suffered during their wandering, their children would benefit from their example, as they faced their own battles in their homeland. Basil's immediate family likewise benefitted from the suffering endured during their ancestors' retreat. It is no coincidence, Gregory argues, that Basil's family lived lives that reflected this flight to Pontus. All the members of Basil's family dedicated themselves to an ascetic lifestyle, as if they too were in the wilderness. The legacy of the flight was thus passed on to each child, Gregory insists, and it served as the very foundation of Basil's virtue and success as the future bishop of Caesarea.

With this past of Christian flight in mind, Gregory turns to Basil's childhood and intellectual training. Exceedingly well educated and ambitious, Basil stood out from an early age. Once he and Gregory encountered one another at school, their friendship blossomed instantaneously, although it was only in Athens that the two men became inseparable. In many instances, Gregory describes their friendship as uneven. He had to protect Basil from the cruelties of adolescence, as when he claims to have sheltered Basil from a hazing ritual at the baths and, later, a conspiratorial attempt to humiliate Basil in an oratorical game of logic. In his early years at least, Gregory made every effort to go to battle on his friend's behalf, for the love shared between the two men was superhuman: "We seemed to have one soul inhabiting two bodies" (Orat. 43.20). It was with great pain and heartbreak that the two young men were eventually separated by the responsibilities of adulthood, and Gregory could no longer protect his dear friend.

Halfway through the speech, Gregory describes one of the first major conflicts Basil was forced to endure alone. He appears to have clashed with the bishop of Caesarea (whom Gregory does not name). Ill equipped to face this challenge on his own, Basil fled to Pontus. Thus it is not as a bishop but as a committed ascetic that Basil's initially flees, a notable contrast with Athanasius. He was welcomed in the familiar deserted landscape of Pontus, Gregory states, by Elijah and John,

39. Gregory favors the terms ermia and oros to describe the location of their retreat. Like Athanasius, he uses the terms interchangeably. 
"those professors of austerity" (Orat. 43.29). This retreat transformed Basil. It is while he was in the desert that Basil decided to dedicate himself to the clerical office as a priest. His return is thus made all the more glorious. Now, Gregory proclaims, Basil was able to withstand any opposition. And he returns to Caesarea to face his greatest challenge yet: he must take on a warring, heretical emperor.

The emperor Valens, who also goes unnamed in this text, is described as "most fond of gold and most hostile to Christ, infected with these two most serious diseases, insatiate avarice and blasphemy; a persecutor in succession to the persecutor [Valentinian I], and in succession to the apostate [Julian]" (Orat. 43.30). Valens was a rueful opponent, indeed, and one worth returning from the desert to take on. Trained in the desert and no longer in need of defense from his childhood protector, Gregory, Basil stands boldly as the defender of the church. We are to conclude that his retreat was both necessary and beneficiary, as it guaranteed his victory. ${ }^{40}$

While Basil waged his epistolary war, we learn that other defenders of the faith were cast out of their bishoprics. The enemy, Gregory reports, used a variety of attacks: "Exiles, banishments, confiscation, open and secret plots, persuasion (where time allowed), [and] violence (where persuasion was impossible)" (Orat. 43.46). Gregory is careful to make a distinction between forced displacement and temporary retreat. The former is a weapon used against the church; the other, Christian flight, is described as a time of training that prepares the Christian soldier for battle. While Basil's conflict with Valens raged on, he came into contact with a formidable foe: an imperial representative baptized by the "other party" - in other words, a heretic at the service of the empire. This prefect attempted to intimidate Basil by threatening him with traditional forms of Christian persecution, namely, violence and exile. Basil, however, scoffed at these threats: "'Confiscation, banishment, torture, death. If there is nothing else', said Basil, 'threaten me with that, too, for none of these you mentioned can affect me. . . . As for exile, I do not know what it is, since I am not circumscribed by any place nor do I count as my own the land where I now dwell or any land into which I may be cast. Rather all belongs to God, whose passing guest I am.'” (Orat. 43.49). The false Christian, Gregory announces, has met his match. No threat of violence or banishment would stir the true Christian. Basil carried with him the memory of the desert. He knew that his authority was neither manmade nor tied to any one space. No threat of displacement could frighten him, because he had already faced the wildness of the desert, and he carried that knowledge with him wherever he went.

40. Gregory of Nazianzus, Orat. 1, 2, 26, 33; Ep. 107-14, 116-19; and Carm. 2.1.1.34-48, also uses the language of spiritual purification as a repetitive act, due to the nature of the ecclesiastical office, which exposes one to constant pollution. The need for retreat to expunge this sinful pollution further supports my assessment of Gregory's desire to flee and to return ready for battle. I am grateful to Bradley Storin for drawing my attention to this point in private correspondence and for his helpful feedback on this chapter. 
Gregory states that even the emperor was impressed with Basil's emboldened response, "for even the enemy can admire a man's excellence" (Orat. 43.51). Nevertheless, Valens signed a decree calling for Basil's removal, and it appeared that the bishop would soon be dethroned. What Gregory describes next is particularly interesting for our purposes here. Basil was not exiled. Instead, the emperor's son was suddenly struck with an illness. "There was the sentence of banishment, here the decree of sickness. The hand of the wicked scribed was restrained, and the saint was preserved, and the man of piety presents to us by the fever that brought to reason the arrogance of the emperor" (Orat. 43.54). Like the young prince, we soon learn that another has fallen ill. The unnamed prefect standing in as the emperor's liaison was also struck down. Sufficiently humbled, the false Christian then sought out the aid of the saint: "I own that you were in the right; only save me!" (Orat. 43.55). ${ }^{41}$ Gregory triumphantly proclaims that all threats of Basil's removal were quickly forgotten. Basil's faith, forged in the desert, proved too strong for his enemies. The man of the desert won the day. Basil, that virtuous man whose family set an important example of Christian flight, lived his life as an example of their pious legacy. After his own brief retreat, Basil returned empowered with the memory of the desert that undermines the threats of any emperor or heretic.

\section{A MODEL RETURN: IN PRAISE OF ATHANASIUS}

Lived memory of the desert also arises in another funerary speech and focuses on a man we have met in the desert before. Gregory of Nazianzus's lesser-known oration on Athanasius tells us a great deal about not only his theory of Christian flight but also how the Athanasian legacy was intimately tied to a vision of the orthodox city-just not the city we might expect. For Gregory of Nazianzus, the road from Nicaea ends not in Alexandria but in Constantinople. The speech, In Praise of Athanasius, was delivered in 380, on the eve of the seventh anniversary of Athanasius's death. Gregory's account of Athanasius's precarious position in Alexandria signals the politics during the former's shaky tenure in the city of Constantinople and resonates with the instability of so many fourth-century urban episcopacies. Constantinople, Antioch, Alexandria, and Nicomedia stand at the center of the battle over Nicaea's legacy and the Theodosian project. The panegyric was delivered at a time of significant theological uncertainty and provides us with a unique look into how Athanasius's legacy as an exile must be reconciled with his legacy as an ardent defender of Nicaea.

41. This phrase calls to mind other infected and diseased bodies, such as that of the empress Eudoxia in Ps.-Martyrius's Funerary Speech, which I discuss in Jennifer Barry, "Diagnosing Orthodoxy: Ps.-Martyrius's Funerary Speech for John Chrysostom," Journal of Early Christian Studies 24, no. 3 (2016): 395-418. 
Much like Gregory's speech on Basil, this oration follows a standard literary formula that lauds the efforts of the chief subject but, for our purposes, the use of a panegyric simultaneously bolsters the authority of the speaker. ${ }^{42}$ Others have noted, for example, how Gregory's funeral oration on Basil helped to recover his own questionably orthodox reputation after his flight from Constantinople. In this earlier eulogy on Athanasius, the Alexandrian's reputation as a staunch supporter of Nicaea also serves as a way for Gregory to affirm his pro-Nicene position, despite his ties to a pro-Meletian contingent in Antioch. This grand oratory display may have further strained his relationship with Alexandria.

The speech is broken into three parts. The first section is meant to establish Athanasius as the legitimate heir to the Alexandrian patriarchate. The second section then interprets the bishop's desert sojourn, although it departs slightly from Athanasius's own theory of exile. In the third and final section, Gregory recounts Athanasius's glorious return and reaffirms his legitimacy as the one true bishop of Alexandria and champion of Nicene orthodoxy.

Two details are worth noting about this particular speech that will help us to see how Gregory uses Athanasius's theory of exile to establish a pro-Nicene platform. First, Gregory states that he does not intend to write a history of the bishop's life. The professed goal of the speech is to praise the life of a virtuous man whose example is worth glorifying: "To speak of and admire him fully would perhaps be too long a task for the present purpose of my discourse, and would take the form of a history rather than of a panegyric" (Orat. 21.5). Instead, Gregory's purpose is to focus on specific details in Athanasius's life that demonstrate why he is the rightful heir of Alexandria despite, if not because of, his exile(s).

Second, Gregory is clearly familiar with Athanasius's vita of the desert monk Antony. While expressing his own concerns about composing an entire life of the Alexandrian bishop, he notes that it should be, "for the pleasure and instruction of posterity, as he himself wrote the life of the divine Antony, and set forth, in the form of a narrative, the laws of the monastic life" (Orat. 21.5). This latter detail is significant because it is from the vita that Gregory draws and develops Athanasius's theory of exile as a desert askesis.

As we saw in the previous chapter, the desert functions for Athanasius of Alexandria as a heterotopia. It is a space where he reimagines that place from which he is absent. The city of Alexandria is reflected both in the real and in the imagined space of the desert-the desert has been made into a new city. The desert thus functions as a counterspace to which Athanasius has been banished. It also functions as a space that both reflects and reinvents the space he aspires to reinhabit. The city in the desert, the new Alexandria, is a city devoid of heresy, as the

42. Tomas Hägg, Philip Rousseau, and Christian Høgel, eds., Greek Biography and Panegyric in Late Antiquity (Berkeley: University of California Press, 200o), 1-28. 
incarnated truth-the bishop or monk-transforms the very spaces he inhabits. This process is possible only through Christian flight.

Before we turn to his adoption of Athanasius's work, let us begin where Gregory does, with an explanation on why Athanasius matters in the construction of a pro-Nicene position, when so much of Athanasius's life was spent defending his own legitimacy as the bishop of Alexandria. Gregory starts the speech with a description of Athanasius's background, which includes both a secular and a religious education. "He was brought up, from the first, in religious habits and practices, after a brief study of literature and philosophy, so that he might not be utterly unskilled in such subjects or ignorant of matters that he had determined to despise. ... Thus brought up and trained, as even now those should be who are to preside over the people and take the direction of the mighty body of Christ" (Orat. 21.5-6). Athanasius strikes a careful balance between philosophical study and scriptural knowledge. He neither confuses the two disciplines nor misinterprets the order of importance for correctly managing the body of Christ.

Gregory then states that Athanasius is the true successor to the Alexandrian throne not because he seized his throne through "bloodshed and oppression" (unlike George of Cappadocia or Macedonius of Constantinople), but because he did so in an "apostolic and spiritual manner" (Orat. 21.8). Thus any rival to the Alexandrian throne only provides further proof of Athanasius's legitimacy.

For unity in doctrine deserves unity in office, and a rival teacher sets up a rival throne; the one is a successor in reality, the other but in name. For it is not the intruder, but he whose rights are intruded upon, who is the successor, not the lawbreaker, but the lawfully appointed, not the man of contrary opinions, but the man of the same faith; if this is not what we mean by successor, he succeeds in the same sense as disease to health, darkness to light, storm to calm, and frenzy to sound sense. (Orat. 21.8)

Gregory insists that the doctrinal unity Athanasius represents is grounded in Nicaea. As a promoter of the Nicene cause himself, Gregory identifies the disease and frenzy that threatens to overthrow orthodoxy as Arianism. As is common in heresiological discourse, he provides a stock account of the rise of Arianism: the heresy is born with Arius and then draws in all those heretical instigators who challenge the authority of the council of Nicaea. Much like Athanasius's take on this heretical faction, all who oppose Nicaea are easily lumped together. Following in this logic, Gregory crowns Athanasius as Nicaea's chief defender.

Athanasius's credentials are secured by his philosophical training and his impeccable character. This combination gives him a privileged position among his peers and elders at Nicaea even before he achieves any official rank: "Though not yet ranked among the bishops, he held the first rank among the members of the Council, for preference was given to virtue as much as to office" (Orat. 21.14). By way of contrast, Gregory provides a detailed account of Athanasius's rival, who is a mere vagabond hailing from Gregory's own Cappadocia, the most deplorable of characters: 
There was a monster from Cappadocia born on our farthest confines, of low birth, and lower mind, who by blood was not perfectly free, but mongrel. ... After passing, as exiles, do from country to country and city to city, last of all, in an evil hour for the Christian community, like one of the plagues of Egypt, he reached Alexandria. There, his wandering being stayed, he began his villainy. Good for nothing in all other respect, without culture, without fluency in conversation, without even the form and pretense of reverence, his skill in working villainy and confusion was unequaled. (Orat. 21.16)

George of Cappadocia is the perfect literary foil: As ignorant as Athanasius is learned, George is a mongrel whose patrilineage is mixed, whereas Athanasius is the successor not only of Alexander, but also of the apostle Mark. Most importantly, Gregory asserts, George of Cappadocia is a wandering exile. George is a foreigner, a voluntary exile who wanders from country to country. We might recall that this is the same argument used against Athanasius by the emperor Constantius II (Athanasius, Apol. Const. 31). This detail establishes Gregory's depiction of Athanasius's exile-or, as he will eventually identify it, his "illustrious banishment" - as a mark of pride because it is the result of persecution. The term initially used for exile for both George and Athanasius is fugadeia, but after Athanasius returns from the desert, the term used is ekdemia.

In this speech, exile transforms and is transformed by Athanasius's ascetic retreat. The shift in terms also appears to accommodate his transformative experience in the desert. Athanasius does not wander from country to country or city to city. During his exile, he plants himself among the ascetics of the desert:43 "Then he was in retirement, and arranged his exile most excellently, for he took himself to the holy and divine homes of contemplation in Egypt, where secluding themselves from the world, and welcoming the desert, men live to God more than all who exist in the body" (Orat. 21.19). Even though Athanasius is a displaced bishop, he uses his time in the desert to reaffirm ecclesiastical authority among the desert ascetics. Gregory envisions Athanasius's exile as a serendipitous moment: it provides the desert monks with an authoritative guide to intervene on their behalf. Athanasius not only resides among the desert monks but also instructs them; he acts as a bishop in the desert as if it were the city. Unlike his monstrous counterpart, who sows discord and confusion, Athanasius cultivates peace and unites two seemingly opposing ways of life, those of monastic seclusion and communal life, "by showing that the priesthood is capable of contemplation, and that contemplation is in need of a spiritual guide" (Orat. 21.19).

Gregory goes on to expand upon Athanasius's theory of exile as a desert askesis in order to explain why this time in the desert was necessary. In the Life of Antony,

43. This is an interesting contrast. In Athanasius's Defense before Constantius, Constantius describes Athanasius as a wandering exile in the Letter to the Auxumis Princes, where it is Athanasius who wanders from city to city. 
the desert is a reflection of the Alexandrian city as both a real and imagined space; the desert exists as itself, but it has also been reimagined as a city from which Athanasius is noticeably absent. This literary theme takes on new life as the monk Antony (the bishop in disguise) flees into the desert. Antony both flees into and begins to embody the desert space. The politeia is not only the location of civilization but also, for Athanasius (by way of Antony), a shared way of life found not in the typical city, but in the heterotopic city of the desert.

Gregory builds on this heterotopic vision in his speech. Instead of confining the truth to one physical landscape, like Athanasius's Alexandria reflected in the Nitrian desert, he mobilizes the desert by embedding it in the monk-bishop. The desert askesis transforms into a way of life and serves as a guide for others in a manner that, as David Brakke has argued, defines Athanasius's larger ascetic program: "[Gregory] made Athanasius the virtual founder of monasticism as an organized, disciplined phenomenon within Christianity: 'Whatever he thought was law to them [the monks], and they rejected whatever did not seem good to him. To them his teachings were the tablets of Moses, and their veneration of him surpassed what human beings owe to the saints." 44 The monastic life is not simply about bodily retreat; it is a way of being: "Thus he combined the two, and so united the partisans of both calm action and of active calm, as to convince them that the monastic life is characterized by steadfastness of disposition rather than by bodily retirement" (Gregory of Nazianzus, Orat. 21.20).

To further support his point, Gregory invokes the biblical king David: "Accordingly the great David was a man of at once the most active and most solitary life" (Orat. 21.20). Athanasius, like David, gains a deeper understanding of the contemplative life during his time in the desert and then carries this symbiotic relationship between the active and the solitary with him back into the city. It no longer matters where the bishop resides, because the life of the ascetic always resides in the person of the orthodox bishop. Through Athanasius, ecclesiastical authority is reconfirmed in the desert and activated in the city.

Athanasius's exile is ultimately only temporary. After Athanasius returns to the city, Gregory insists that the bishop's exile, as well as the exile of all his fellow Nicene bishops, was an "illustrious banishment." Gregory states, "Our champion was restored from his illustrious banishment, for so I term his exile [ek tēs kalēs ekdēmias ho athlètēs houtō gar egō kalō . . . phygēn]" (Orat. 21.27). To be clear, Athanasius is no vagabond wandering aimlessly, like Oedipus; he is a victim of persecution who takes full advantage of his circumstance by providing others with pastoral direction. Athanasius's exile is indeed a desert askesis, but a temporary one. James Goehring has noted elsewhere that Gregory does not see the desert as a classical cultured retreat (otium liberale). ${ }^{45}$ Much like his description of the

44. Brakke, Athanasius and Asceticism, 14.

45. Goehring, "Dark Side of the Landscape" 445-46. 
desert in his letter to Basil (Ep. 4), the desert is filled with spiritual dangers and hardships. According to Gregory, the desert is a training ground from which the bishop ultimately must return. ${ }^{46}$

To prove this point, in the final section of the oration, Athanasius's illustrious banishment is quickly overshadowed by a lengthy and elaborate description of his reentry into the city. ${ }^{47}$ Gregory depicts Athanasius's return much like Christ's procession into Jerusalem: "he rode upon a colt"; "he is welcomed with branches of trees"; and there "were those who went before with shouts and followed with dances" (Orat. 21.29). Once reinstated, Athanasius also "cleansed the temple of those who made merchandise of God" and "those who had been wronged he set free from oppression" (Orat. 21.30). ${ }^{48}$ The savior of Alexandria has returned once more and is more glorious than before.

For Gregory, Athanasius is the ideal monk-bishop. His exile is not physically bound to the desert, but the desert is carried with him into the active life of the city. Truth is first affirmed in the desert and then put to use in the city center. In the final paragraphs of the oration, Gregory draws us back to another city, prompting us to look to Nicaea. He is careful to note that the most important work Athanasius did was for the Nicene cause. It is for this reason alone that Athanasius suffered his illustrious banishment. Athanasius's temporary withdrawal and triumphant return were ultimately designed for the greater good of orthodoxy. This message is not meant for Alexandria alone but is carried into and proclaimed in that beacon of Nicene orthodoxy, Constantinople.

\section{CONCLUSION}

Gregory reimagined Athanasius's exile as an ascetic retreat to reaffirm this fleeing bishop's reputation as a persecuted orthodox figure. He also used Athanasius's exilic discourse to emphasize his return to the city as a transformed man. The true Alexandrian bishop was ultimately made over into the ideal monk-bishop ready to take up his episcopal throne after his illustrious banishment. Gregory transformed that heterotopic vision of the desert into an embodied state of active civic engagement. The monk-bishop serves as a model for the new ecclesiastical ideal: the true monk-bishop easily transitions back into the active life of the city because he holds onto the solitary life of the desert.

It is in Gregory's funerary oration on Basil of Caesarea that we begin to see how Christian flight is intimately wedded to ascetic training. Only when we accept

46. Gregory of Nazianzus, Letter to Basil, Ep. 4.

47. In this last section, Gregory expands upon Athanasius's reflection on his return to Alexandria after his second exile in 346 in $H$. Ar. 25.

48. Gregory does take note of one last exile under Julian but does not include Athanasius's exile under Jovian. 
Gregory's logic is the bishop capable of taking on his heretical foes. In his efforts to promote and secure Nicene orthodoxy, Gregory of Nazianzus makes use of Nicaea's most ardent defender, Athanasius of Alexandria. Unlike Athanasius, however, Gregory had to stress the impermanence of exile. He did this by making it clear that a bishop's flight was never intended to be an end in itself. Basil's greatest triumphs are brought about in Caesarea, and Athanasius's flight is significantly overshadowed by his return. Gregory's emphasis on return was a litmus test not just for Basil and Athanasius but for later bishops as well. If a bishop found himself exiled, his orthodoxy was affirmed by his glorious return. For it is clear that the orthodox bishop must live on not in the desert but firmly seated on his episcopal throne.

Persecution continued to play an important role in legitimizing a forced departure, much as Athanasius argued. The legacy of imperial persecution remained a powerful one. Any bishop under threat could easily invoke this claim, as we saw with Demophilus's reference to Matthew 10:23. As later pro-Nicene historians would see it, Demophilus does not return, and that is proof enough that his flight is no illustrious banishment. Gregory effectively assembled several important components, such as Christian flight, persecution, ascetic training, and return, in order to create an orthodox formula.

Gregory's panegyric on Athanasius (and his exile) set a rhetorical standard that strategically aligned Constantinople with Alexandria. This alliance would remain a contested one as Antiochene politics continued to clash with Alexandrian power plays. It is only in hindsight and with the recovery of the memory of John Chrysostom, another fleeing bishop of Constantinople, that the battle for the Athanasian legacy will once again play a significant role in the pro-Nicene narrative. In the next chapter, we will explore how John Chrysostom's identity as an exile and his theory of Christian flight posed a significant problem when compared with Gregory's formula. Episcopal exile continued to put orthodoxy at risk, particularly when there was no return in sight. 


\title{
John Chrysostom in Flight
}

\begin{abstract}
For ... if you speak of exile, you mention that which only involves a change of country and the sight of many cities, or if you speak of confiscation of goods, you mention what is only freedom and emancipation from care.

-JOHN CHRYSOSTOM, LETTER TO OLYMPIAS ${ }^{1}$
\end{abstract}

Alliances in the late fourth century were easily made and almost as easily broken. As was the case for Gregory of Nazianzus, with whom you associated often determined your status as an orthodox or heretical bishop. Gregory's use of panegyric to frame both himself and his associates as orthodox was one approach to remembering an orthodoxy firmly in place. John Chrysostom's many relationships-both friendly and hostile-were equally important for the making (or the unmaking) of the orthodox bishop. This bishop of Constantinople produced an expansive epistolary campaign, which was integral to his life as an exile and will be the focus of this chapter. Although these letters did not secure his return during his lifetime, they provide us with a different vision of exile than what we have seen so far-and one that would later cause a great deal of concern for his biographers.

Like many of the fleeing bishops we have examined, John Chrysostom (ca. 349407) had a tumultuous episcopal career. He was exiled twice from Constantinople and died during his second expulsion. But John was not a man of any one city. First as an influential presbyter of Antioch and then as the bishop of Constantinople, he is often noted more for his skills as an orator-his "golden mouth"-than for his particular location. In many ways, this wandering man embodies the transient nature of the late antique bishop. And it is this identity that John used to interpret his identity as an exile. Unlike Athanasius of Alexandria or Gregory of Nazianzus, John does not turn only to saints who fled into the desert or to martyrs of imperial persecution as his literary guides. He also appeals to classical models of exile to create his own exilic discourse. In a curious move, one we have not explored before, this discourse evolves as his identity as an exile appears to become a permanent one.

1. John Chrysostom, Ep. 9. Edition: SC 13. Translation: NPNF1 9 (with some slight alterations). 
John's first exile, and even the earlier years of his second exile, are dependent upon themes of return. But with each new departure, John alters his episcopal identity and the spaces from which he finds himself absent. As his position shifts, so do his descriptions and understandings of exile and its relationship to holy spaces. Even though John was a bishop on the move, he used spatial rhetoric to find and locate orthodoxy. We will begin this chapter, therefore, by looking at how John envisions model cities of orthodoxy, which include his hometown of Antioch and that noble city, Constantinople. By assessing his treatment of another bishop in flight, Meletius of Antioch, we see how John's construction of the sanctity of these cities is created beyond their walls. As we will see, John explores this process of boundary making by examining the life and legacy of his own wandering hero, whose episcopal authority is reaffirmed by his legacy of flight.

We will then turn to consider how John interprets his own experience of flight, which is first evident in his letters to the bishop of Rome, Innocent I (Ep. 7 and Ep. 41). ${ }^{2}$ Then we will examine the evolution of the exilic discourse in his extensive literary corpus composed during the early stages of his second exile. As we will come to see, John's exilic discourse shifts and changes to meet the needs of a man intent on return. Finally, we will investigate two treatises composed at the end of his life that sum up John's resolution as a permanent exile. Like his hero Meletius, John resigns himself to the fate that he will not return-a detail that will remain a damning one.

\section{A MAN IN FLIGHT: JOHN CHRYSOSTOM}

John Chrysostom was born in Antioch around 349. ${ }^{3}$ Most scholars agree that John's mother was a Christian and his father a non-Christian civil servant. Due to a relative amount of material affluence, John was well educated and famously schooled by the rhetorician Libanius. ${ }^{4}$ John was recruited and then baptized by the

2. Letters 1 and 2 to Innocent I are found in Palladius, Dia. 2. Both Wendy Mayer and Geoffrey Dunn refer to the collection of John's letters to Innocent as Epistles 7 and 41, respectively. Translation in consultation with Dunn's prepublished translations, which were made in preparation for CCSL and are available on Wendy Mayer's webpage: www.academia.edu/581150o/Translation_Letter_1_to_Innocent_bishop_of_Rome and www.academia.edu/5811509/Translation_Letter_2_to_Innocent_bishop_of_ Rome. Edition: SC 342, 68-95. Epistle 7 (Letter to Innocent I) is John's first letter to Innocent I, while Ep. 41 is a follow-up message. These letters are sometimes referenced as Epistles 1 and 2, respectively, but I follow the new numbering of the letter collection by Dunn, found in his "Date of Innocent I's Epistula 12."

3. The most extensive biography of John Chrysostom is still J. N. D. Kelly, Golden Mouth: The Story of John Chrysostom - Ascetic, Preacher, Bishop (Ithaca, NY: Cornell University Press, 1998). Many scholars have supplemented and critiqued Kelly's contribution, but it still sets the standard. The Centre for Early Christian Studies hosts an extensively curated (and growing) bibliography that is invaluable to Chrysostom scholars, www.cecs.acu.edu.au/chrysostombibliography.html.

4. For a review of Libanius's school, see R. Cribiore, The School of Libanius in Late Antique Antioch (Princeton: Princeton University Press, 2007). For a recent discussion of his so-called religious identity 
then-contested bishop Meletius. He appears to have dedicated his life to austere ascetic discipline, possibly under the auspices of two significant spiritual teachers, Diodore and Carterius. Eventually, he was ordained a priest by Meletius's successor, Flavian, and continued to develop his pastoral skills and responsibilities in Antioch, which soon gained him a reputation. John was elected bishop of Constantinople in October-November 397 and, after a short tenure, was sent into exile for the first time in September-October $403 .{ }^{5}$ His second and final expulsion from Constantinople took place on the June 20, 404, and he died while in exile in September 407.

Despite the large amount of evidence, there was no clear and discernible cause for John's two exiles. As was the case with Athanasius, several charges were made against him, but the ultimate reason for his exile remains a mystery. Nevertheless, it is evident that the events leading up to John's two exiles were driven by his controversial election as bishop of Constantinople (ca. October 397). After the death of his predecessor, the bishop Nectarius, many vied for the position as the ruling patriarch of Constantinople. John was said to have been "secretly" elected by the young emperor Arcadius-or, as J. N. D. Kelly insists, appointed under the influence of Eutropius, whom Sozomen states was an infamous eunuch and superintendent to the imperial sacred bedchamber. ${ }^{6}$ Yet, as Wendy Mayer has aptly pointed out, John's election was hardly incidental; it was steeped in a long history of conciliar politics. ${ }^{7}$ Tensions arose once it was clear that John would remain actively involved in Antiochene politics upon his election. For example, he proved to be an avid supporter of the Meletian faction in Antioch under the leadership of bishop Flavian.

The fact that one of John's first acts is to use the status accorded by the see to approach Rome to secure approval of Flavian's election as bishop of Antioch and therefore approval of the claim by the faction to which John was loyal to be the legitimate orthodox Nicene church in that city, confirms his partisan interests in the affairs of the Meletian-Nicene faction at Antioch and suggests that his election was indeed no accident. ${ }^{8}$

in relationship to John, see Isabella Sandwell, Religious Identity in Late Antiquity: Greeks, Jews, and Christians in Antioch (Cambridge: Cambridge University Press, 2007).

5. See Claudia Tiersch, Johannes Chrysostomus in Konstantinopel (398-404). Weltsicht und Wirken eines Bischofs in der Hauptstadt des Oströmischen Reiches, Studien und Texte zu Antike und Christentum 6 (Tübingen: Mohr Siebeck 2002), 327-53. Tiersch reconfirms that John's first exile must have taken place between September and October 403 and discusses arguments for this date, as well as the reasons behind his exile.

6. Kelly, Golden Mouth, 105-6. Claudian composes a scathing poem about Eutropius's questionable conduct in Against Eutropius. For this, and for a description of Eutropius's treatment in non-Christian texts, see Jacqueline Long, Claudian's In Eutropium: Or, How, When, and Why to Slander a Eunuch (Chapel Hill: University of North Carolina Press, 1996).

7. Wendy Mayer, "John Chrysostom as Bishop: The View from Antioch," Journal of Ecclesiastical History 55, no. 3 (2004): 455-66.

8. Ibid., 459. For a more detailed argument for why the election of Flavian was so controversial as well as the Antiochene politics that secured John's election, see in particular ibid., 460-62. I will address this controversy in more detail in chapter 6. 
The history behind this controversial endorsement linked Constantinople to Alexandria through that long-standing rivalry in Antioch. The support of this particular faction would ensure problems with Alexandria, as we saw in the previous chapter, when Gregory of Nazianzus's clash with Timothy of Alexandria eventually resulted in his flight from Constantinople. John's ongoing involvement in the battle for control of Antioch, and Asia Minor more broadly, earned him the reputation as a meddlesome bishop and a threat to ecclesial autonomy.

\section{HOW TO CONSTRUCT A MODEL CITY: ANTIOCH}

To understand why John was an important bridge in pro-Nicene Christian memory, it is helpful to briefly revisit the complex Antiochene politics that gave way to his own entrance into Christianity. ${ }^{9}$ In the aftermath of the Nicene council, Eustathius, then bishop of Antioch, was exiled, as early as 326 or as late as $331 .^{10}$ Again, it is difficult to reconstruct why or even how a given bishop was expelled from his see. According to Athanasius, Eustathius was exiled for insulting the emperor Constantine's mother (Athanasius, $H$. Ar. 4.1), although later ecclesiastical historians would argue that it was for his heretical leaning or even his insatiable sexual appetite. The ultimate cause remains unknown. ${ }^{11}$ What we do know is that Eustathius's exile ushered in a period of upheavals that placed Antioch at the center of Nicene politics and intense theological debates.

Soon after Eustathius's departure, he was replaced by the first of more than a few anti-Nicene bishops in Antioch. It appears that the anti-Nicene faction had a strong hold on the episcopal office until Eudoxius departed for Constantinople in 36o. The fallout that ensued after his promotion was due in no small part to the differing theological as well as political parties represented in and around Antioch. This fight over the episcopacy resulted in at least three (and briefly four) Christian factions crossing the theological spectrum of the Trinitarian controversy. We will pay attention to the battle that raged after Eudoxius's move to Constantinople, because it was a move that would be replicated by John (equally controversially), and because it is significant for understanding his exilic discourse (Theodoret, Eccl. Hist. 2.23). Eudoxius's advancement left the post in Antioch up for grabs and paved the way for an ongoing competition between bishops for control. Meletius

9. For a full assessment of this controversy, see Thomas Karmann, Meletius von Antiochien. Studien zur Geschichte des trinitätstheologischen Streits in den Jahren 360-364 n. Chr., RST 68 (New York: Lang, 2009); and Karmann, "Johannes Chrysostomus under der Neunäznismus. Eine Spurensuche in ausgewählten Predigten des antiochenischen Presbyters," SacEr 51 (2012): 79-108.

10. For a review of current debates on the dating of his exile, see Sara Parvis, Marcellus of Ancyra and the Lost Years of the Arian Controversy 325-345 (Oxford: Oxford University Press, 2006).

11. Socrates, Eccl. Hist. 1.24, states that Eustathius was exiled for his Sabellianist teachings, while Theodoret, Eccl. Hist. 1.20-21, cites an accusation of adultery. Edition: L. Parmentier, F. Scheidweiler, and G.C. Hansen, Theodoretus Cyri, Kirchengeschichte, 3rd ed., GCS 19 (Berlin 1998). Translation: NPNF2 3. 
was elected in Eudoxius's stead but was unable to hold onto his position for more than a few months, possibly an even shorter period of time than that. He was replaced by Euzoius, who was a homoian favorite. With Constantius's death and Julian's recall of all Christian exiles in 361, chaos ensued as Meletius returned. There were now two bishops of Antioch. A third was soon added to the mix with the appointment of Paulinus, the favored candidate of the Athanasian party out of Alexandria. These three bishops embodied, at least in hindsight, the fallout of Nicene politics. ${ }^{12}$ For example, Euzoius was remembered as a staunch anti-Nicene bishop, and Paulinus firm in his pro-Nicene position. ${ }^{13}$ Meletius, however, occupies a much more ambiguous position within Christian memory.

According to Theodoret, a fifth-century ecclesiastical historian, Meletius was elected by an anti-Nicene group "in the hope of establishing their impiety" (Theodoret, Eccl. Hist. 2.27). ${ }^{14}$ Little did this heretical faction know, according to this same pro-Nicene historian and defender of Meletius, "the maintainers of apostolic doctrine, who were perfectly well aware of the soundness of the great Meletius." At least from Theodoret's point of view, it appears that the true orthodox community had a different plan in mind for Meletius. We will return to this perspective in chapter 6. For now, it is important to note that Meletius's identity as an orthodox bishop was questionable at best from the perspective of fifth-century pro-Nicene historians, and different accounts will remember the end of his life in starkly different ways.

As we know by now, the battle over Antioch was not easily resolved and would be a source of contention until 415, when it appears the Meletian party won the day. Yet Meletius remained at the center of this conflict and was frequently painted as a victim. Much like Athanasius, he was exiled multiple times, in 360, 364, and 369. His critics would point to his exiles as evidence of his guilt, and his entire episcopacy appeared to be defined by his displacement. Socrates, for example, would question Meletius's claim to the episcopal see after Paulinus's election. He noted that Meletius's status as an exile undermined his claim and was careful to note that Paulinus was never forced to flee his post (Socrates, Eccl. Hist. 5.5).

Before his final expulsion, sometime around 369, Meletius was credited with bringing John Chrysostom into the Christian fold. ${ }^{15}$ But what flavor of Christianity John would adopt was left to the ecclesiastical historians to determine, well after the fact. His ongoing commitment to Meletius remained shrouded in controversy both during his lifetime and after his death. This was made most clear in a text

12. A fourth man, Vitalis, was elected in 375 .

13. After Euzoius died, he was replaced by Apollinarius, who stood in as the Arian representative.

14. For a detailed discussion on Theodoret's role in how pro-Nicene historians will remember Antioch see chapters 5 and 6 .

15. Theodoret, Eccl. Hist. 5.2, would argue that Meletius did not die as an exile but returned after the death of Valens (378). 
written while he was still in Antioch, in which John praises his mentor. Before we turn to John's career as an exile and his epistolary efforts to construct and defend his orthodoxy, we will begin by examining his mentor's identity as a fleeing bishop. John's hagiographical reflection in On St. Meletius, much like Gregory's funeral orations, constructs the controversial bishop as a saint worthy of praise, not a man who should be condemned. It will quickly become clear why. This text ushers us into John's exilic discourse, which would shape the path he followed in his mentor's fleeing footsteps.

\section{BISHOPS WHO DIE IN FLIGHT: \\ MELETIUS OF ANTIOCH}

John Chrysostom composed the sermon On St. Meletius while still in Antioch, five years after the famed Council of Constantinople in 380 and Meletius's death. ${ }^{16}$ The homily directly addresses Meletius's first exile and, more importantly, his death in Constantinople. John was not the only pro-Nicene author to praise Meletius after his death. Gregory of Nyssa also composed a funeral oration for the bishop. ${ }^{17}$ Both authors state that Meletius died in Constantinople at the ecumenical council, thus proving his legitimacy as a pro-Nicene supporter and not an Arian in disguise. Despite the strong contingency in Antioch that supported Paulinus, later historians would take their cues from both John and Gregory. Nevertheless, Meletius remained a controversial figure who never fully escaped his Arian past precisely because he posed a direct threat to Alexandrian politics in and around Antioch. By threatening Alexandria, Meletius's legacy had a chance to undermine Athanasius's legacy as well.

On St. Meletius is broken into four sections. The first addresses the strong support for Meletius in Antioch, which seems only to have increased after his death. John then discusses Meletius's difficult history as a perpetual exile, which will be our primary focus here, along with the third section, which addresses Meletius's activity in Constantinople. The sermon ends with John praising the bishop's virtuous activity and affirming the Antiochene community's (as well as his own) ongoing adoration of their deceased leader.

When addressing Meletius's exile and the Meletian faction mourning his loss, John states, "And God yielded, wanting to show both that man's virtue and your courage" (Melet. 4).$^{18}$ His exile was not only for the saint's benefit but also for the benefit of the Antiochene community:

16. John Chrysostom, Melet. Edition: PG 50.515-20. Translation: Wendy Mayer, The Cult of the Saints: St. John Chrysostom (Crestwood, NY: St. Vladimir's Seminary Press, 2006), 43-44, unless otherwise noted.

17. Gregory of Nyssa, In Mel.; Wendy Mayer, "Cathedral Church of Cathedral Churches?” Orientalia Christiana Periodica 66 (2000): 63 n56.

18. We might recall that Cicero makes a similar claim in De re publica. See the introduction for a more detailed description of classical motifs. 
For when he arrived [in Antioch], like Moses in Egypt, and freed the city from heretical error and, by cutting off from the rest of the body the limb that was festering and in an incurable state, brought back uncontaminated health to the majority of the church, the enemies of truth couldn't endure the correction and, stirring up the emperor of the time, expelled him from the city, hoping by this to subvert the truth and overturn the correction of events. (Melet. 4)

The first thing to note is what John purposefully leaves out. At no point does he reference Meletius's initial election from a heretical community, which later historians like Theodoret will be forced to address. Instead, he refers to Meletius's election as a celebratory experience and a correction to the unnamed heretical divisions present in Antioch. Meletius not only freed the Antiochene community but also began to heal them from heretical error. In this text, Meletius's orthodoxy is not in question. Instead, John affirms the saint's orthodoxy by yet again drawing our attention to his exile. He was cast out, John argues, because of his mission. His exile was then proof of his persecution, now a familiar theme.

The reaction to Meletius's expulsion was swift and violent. John insists that the city was so enraged by the decision that they were willing, even desperate enough, to resort to violence. Rocks and stones were thrown at the prefect whose job it was to remove Meletius from the city. Meletius alone was able to protect the prefect and gently correct the grieving city. He was a true leader, John argues, who not only brought healing but also prevented the city from descending into chaos. His reach was so great and his hold over Antioch so steady that even his absence was no deterrent for his continued influence over Antioch's people. In fact, John describes Meletius as carrying the city with him into exile: "And he took the entire city with him when he went off to Armenia" (Melet. 5). The bond between the city and its bishop was so strong that it transcended space and time: "For, although you were situated here and circumscribed by the city, by love's spirit, you were lifted up to Armenia day after day and saw his holy face and heard his most pleasurable and blessed voice, and so came back again" (Melet. 5). This temporary displacement, Meletius's first exile, was not actually a separation but a chance to strengthen the bond between bishop and city in a way that no physical separation could ever sever.

This first exile, although brief - a mere thirty days, according to John-ended in joyous celebration. Meletius's triumphant return, not unlike Athanasius's, as described by Gregory of Nazianzus, was met with great fanfare. Curiously, John does not mention Meletius's subsequent career as an exile or his establishment of a church just beyond the Antiochene walls. Other writers note that Meletius was expelled up to two more times after this initial removal, a detail with which John would have been intimately acquainted and which he even mentions in a later text on the martyr Babylas. In this text, John chooses to turn to the Council of Constantinople and omits the series of expulsions that appeared to undermine his central message. This intentional omission is replaced with John's insistence that the community went with him, even into exile, and appeared to return daily, as the quote above insists. 
John states that the Christian community in Constantinople, where all the churches were summoned, was given the opportunity to witness Meletius's virtue first hand. It is worth noting that it is in Constantinople that Meletius died. What John leaves out is that Meletius was not present in Constantinople as the unquestioned representative of Antioch. At this point, Paulinus appeared to have gained significant popularity, and Meletius's orthodoxy also may have been still doubted, due to the nature of his election by an anti-Nicene faction. To avoid addressing these more difficult issues, John decides to emphasize why Meletius had to die in Constantinople and not Antioch. He assures his readers that Meletius's death spared the city the full weight of grief, which would have shaken it to its very foundations. That his death occurred well beyond the reaches of his flock was a divine act of mercy and, we soon learn, instructional as well.

Meletius died without a firm grip on his episcopal position back in Antioch. If we follow Gregory's logic, the triumphant return justifies the exile. Meletius's death outside of Antioch was clearly troubling for John, especially when Meletius's legacy remained so uncertain. John takes full advantage of Meletius's history of displacement. Exile, as we now know, served as a sign of persecution, an idea John is all too happy to exploit. The efficacy of the return, however, was paramount to ensuring that the bishop's persecution was not ill-founded or construed as proof of guilt, which explains why John places great emphasis on Meletius's initial triumphant return. Yet Meletius's career as an exile did not end there. From John's perspective, Meletius had to die in Constantinople not as a failed exile but as the true bishop of Antioch. His ongoing support of Meletius's successor, Flavian, makes this point all the more significant and explains why John's defenders would go to great lengths to make similar claims, even if they admit that Meletius's election was questionable. We will pick up Meletius's legacy within the pro-Nicene narrative in greater detail in chapter 6 . For now, it is enough to note that John was well aware of how exile could easily slip into an admission of guilt, and he did his best to cover this up.

Christian flight reread as exile is an effective way to justify a bishop's displacement. Biblical examples of fleeing men were a significant part of this reasoning, as we saw in Athanasius's Defense of His Flight. John also made use of this literary strategy when he compared Meletius's experience of flight to the biblical narrative of the three boys who were tried by the fire while in exile (Dan 3:1-30). John remarks:

And so, at that time, he [Meletius], too, was present there [in Constantinople]. And, just as in the case of the three boys, when they were about to be heralded and crowned, they extinguished the fire's force, trampled on the tyrant's pride, put on trial every form of impiety, and had the entire world watching them as spectators (for although the satraps from all over the world and consuls and prefects had been summoned for another reason, they became spectators of those athletes), this is how it turned out, too, on that occasion, with the result that the theater became magnificent 
for that blessed man. Summoned for another reason, the bishops who administer the churches all over the world were in attendance and watched that holy man. (Melet. 7, emphasis mine)

Particularly in that last statement, John challenges all who knew Meletius as a fleeing bishop and thus doubted his orthodoxy. While he may have died outside of Antioch-a space on which he only ever had a tenuous hold-his death proved instructive. Meletius, like those three youths, was tried and his virtue confirmed outside his homeland. If we follow John's earlier point that the city was carried into exile along with Meletius, his identity as an exile would hardly matter. It is not the city that makes the man, but the man who makes the city-even when he is outside its walls. John concludes that any who still question Meletius's legitimacy are no better than that tyrant who threw the youths into the fire. Meletius's status as the true bishop of Antioch remained intact. He was a holy man, found in a foreign land and tried by fire. His death in Constantinople serves as proof of his legitimacy. The fact that the most holy council members in that most holy city bore witness to this trial further affirms Meletius's orthodox identity. This is not a story of failure, John insists. It is a story of unwavering success, due in no small part to Meletius's death in Constantinople.

\section{HOW NOT TO FLEE: THEOPHILUS OF ALEXANDRIA}

The city, as a site of Christian authority, was an important and consistent theme in John's literary life. Peter Brown proclaimed that John's golden tongue sounded the death knell of the ancient city, but Aideen Hartney thinks the bell may have been rung a bit prematurely. ${ }^{19}$ Hartney mined John's many homilies for evidence of how the bishop contributed rhetorically to the changes that took place in the city during this transformative period in antiquity. John's reorganization of city life away from traditional views of civic engagement was no rejection of the city itself. Instead, Hartney insists, John reinterpreted the city as one more site-if not the site-for the formation of Christian identity and orthodoxy.

Christine Shepardson provides a careful analysis of John's efforts to control urban space through spatial rhetoric used in his Discourses against Judaizing Christians. ${ }^{20}$ The Antiochene cityscape, in particular, was transformed into a distinctly Christian space by demonizing Jewish and other non-Christian spaces. For example, Shepardson notes how John uses harsh comparisons to create a topophobia

19. See Aideen M. Hartney, John Chrysostom and the Transformation of the City (London: Duckworth, 2004). Hartney pays particular attention to key sermons written by John that help him to articulate the city as a Christian locale and space in which to discover and cultivate an identity.

20. Christine Shepardson, "Controlling Contested Places: John Chrysostom's Adversus Iudaeos Homilies and the Spatial Politics of Religious Controversy," Journal of Early Christian Studies 15, no. 4 (2007): 483-516. 
with regard to the space of the synagogue. ${ }^{21}$ He redefines this Jewish space as the mouth of the devil, ${ }^{22}$ the theater, ${ }^{23}$ or the den of thieves and the inn of prostitutes. ${ }^{24}$ For our purposes here, Shepardson notes how this logic extends beyond the synagogue to any space that appears questionable, such as Jewish festivals or sacred spaces, like the healing shrine found in the cave of Matrona in neighboring Daphne. John also applies this rhetoric to pagan spaces, such as the Temple of Apollo. ${ }^{25}$ Shepardson states, "Through his spatial rhetoric, Chrysostom remapped Antioch (and Daphne), constructing a Christian city and requiring of his congregation 'orthodox' Christian behavior to mirror their 'orthodox' beliefs." ${ }^{26}$ John effectively remaps the Antiochene city into an orthodox space through this spatial rhetoric, which travels with him to Constantinople, much like it did with Meletius.

John's rhetorical creation of the city while he was in Antioch and Constantinople has been well studied, but little scholarship exists on his use of the city when he found himself outside of its walls. John did not recreate the city in the desert like Athanasius did, but he did articulate for the reader an urban space unlike any other in his letters to Innocent I. In order to accomplish this goal, he built upon the utopian ideals of the city found in his Homily on Matthew to express the absolute destruction that results once he is exiled. ${ }^{27}$ The ideal city, or politeia, captures the vision of absolute justice and proper order. There can be no heavenly politeia without justice. The bishop's presence is necessary to maintain order and secure the borders around his city, even if he is just beyond those borders, rather than in the city itself. John's conflict with another bishop from another powerful city, Alexandria, thus becomes another important point for discussing the evolution of John's exilic discourse.

John's link to Antioch was not the only theologically and politically infused urban space that would serve to define and unravel his episcopacy in

21. Shepardson relies on the theory of topophobia to show how John actively instills a sense of fear in the process of demonizing non-Christian spaces. See also Yi-Fu Tuan, Topophilia: A Study of Environmental Perception, Attitudes, and Values (Englewood Cliffs, NJ: Prentice Hall, 1974).

22. Shepardson, "Controlling Contested Places," 504.

23. Ibid., 507.

24. Ibid., 509.

25. Christine Shepardson, "The City, a Text: Inscribing Orthodoxy in Antioch's Landscape" (paper presented at the North American Patristics Conference, Chicago, IL, May 23, 2013).

26. Shepardson, "Controlling Contested Places," 515.

27. John Chrysostom, Hom. Matt. 12-17. Edition: PG 57,13-58,794. Here we see parallels with the utopian city-state in Plato's Republic. John would maintain that Plato's republic is "ridiculous," yet the hierarchical structures set in place by John closely follow those found in Plato's interpretation. John has much to say about the faults of Plato and other classical philosophers but, in typical patristic fashion, follows Plato's lead in philosophical discourse. John Chrysostom continues to play with the language of scripture out of Matthew 5:14 (hymeis este to phōs tou kosmou ou dynatai polis krybēnai epanō orous keimenè) as a way to redefine Plato's commonwealth through the use of Christian imagery (Hom. Matt. 15.11-12). 
Constantinople. In addition to his early controversial ecclesial activity in Antioch, John's polarizing personality, evident in his sermons and openly acknowledged by his biographers, appears to have put him at odds with a variety of powerful individuals outside the city. ${ }^{28}$ Theophilus of Alexandria was notably involved in ensuring John's expulsion, and this is frequently commented upon by both his ancient and contemporary biographers. Like John, Theophilus is presented as a meddlesome bishop who oversteps his authority by playing party politics within Constantinople. He is frequently criticized for his harsh tactics and political ambition. As Elizabeth Clark highlights, Theophilus's afterlife presents him in a much harsher light than is probably warranted. ${ }^{29}$ This was due in large part to how John characterized Theophilus's involvement in John's affairs in Constantinople, which are remarked upon in a letter written to the bishop of Rome during his first exile, here referred to as Letter to Innocent I. This letter, along with a follow-up exchange, is found embedded and framed by Palladius's text, Dialogue on the Life of John Chrysostom. ${ }^{30}$ Chrysostom scholars have recently noted that John's first letter to Innocent may not accurately represent what he actually wrote to the bishop of Rome. ${ }^{31}$ Mayer observes: “The letter's authenticity is widely accepted, but a degree of suspicion attaches to the relationship between the version that survives and the original, by virtue of the neat correlation between the careful legalism of the arguments presented in the letter in its present form and its publication within a work framed as a piece of judicial rhetoric." ${ }^{22}$ It appears as if Palladius has taken some liberties with the text to fulfill his own goals, which I highlight in the next

28. While I explore primarily the depiction of John's tenuous relationships with Theophilus and the empress Eudoxia, there were, of course, a variety of other figures who were set against John. One notable figure is Epiphanius of Salamis, whose hostility is noted by both Socrates and Sozomen. Mayer questions this figure's motivations ("John Chrysostom as Bishop," 460-62). See Socrates, Eccl. Hist. 6.12, 14 and Sozomen, Eccl. Hist. 8.14.

29. Clark, Origenist Controversy, 6-10.

30. John's most famous biographer, Palladius of Helenopolis, was born in Galatia. He became a monk in 386 and spent several years in Palestine near the ascetic communities of Melania the Elder and of Rufinus of Aquileia. He would later spend time in Alexandria with Isidore, who was the favored bishop of Theophilus for the Constantinopolitan see before John took the post. (Isidore, like so many others, later fell out of favor with the Alexandrian bishop.) Palladius also spent time in the Nitrian desert, where he became acquainted with the infamous Tall Brothers, and soon traveled further south to become a student of Evagrius of Pontus. He was eventually ordained by Dioscorus and then elected bishop of Helenopolis in Bithynia Prima in 400. For a recent detailed biography of Palladius, see Demetrios S. Katos, Palladius of Helenopolis: The Origenist Advocate (Oxford: Oxford University Press, 2011); and Anne-Marie Malingrey (ed.), Palladios, Dialogue sur la vie de Jean Chrysostome, 2 vols., SC 341-42 (Paris: Paillart, 1988) 2:68-95.

31. For a thorough assessment of this analysis, see Wendy Mayer, "John Chrysostom as Crisis Manager: The Years in Constantinople," in Ancient Jewish and Christian Texts as Crisis Management Literature: Thematic Studies from the Centre for Early Christian Studies, ed. D. Sim and P. Allen, LNTS 445 (London: T \& T Clark, 2012), 129-43. See also Katos, Palladius of Helenopolis, 42-69.

32. Mayer, "John Chrysostom as Crisis Manager," 131. 
chapter. What, then, is possible to reconstruct regarding John's construction of the orthodox city? If we place these letters alongside the Meletian hagiography above, a few overlapping themes stand out.

In his first brief letter to Innocent I, John issued a complaint against Theophilus of Alexandria's wrongful involvement in Constantinopolitan affairs, which led to John's present state in exile. He was intent on demonizing the bishop's activity in and around Constantinople, and he came to the conclusion that the Theophilus's involvement was nothing short of an act of war. Almost immediately, Theophilus is described as an outsider and an enemy to the city and its church who illegally invaded the borders of the city.

This text asks us to reimagine John inside the borders of the city, even though he is writing during his first exile. He begins by lauding the city's glorious past as "the great city Constantinople" (tès megalēs Kōnstantinoupoleōs). This brief indulgence in nostalgia sets up his readers for what will inevitably be its destruction. He then mournfully states that Innocent has no doubt heard of the "lawlessness" (paranomian) that the Constantinopolitans (and he) have had to endure.

Next John appeals to the natural alliance forged between Constantinople and Rome. He appears to be playing on Constantinople's history as the second Rome and may even be appealing to earlier documents that affirm this connection. The city is cited as a "new Rome" in canon 3, drafted at the Council of Constantinople in 381: "The bishop of Constantinople shall have the prerogatives of honor after the bishop of Rome through its being New Rome." ${ }_{33}$ John uses this link repeatedly to unsettle the borders around Rome. By shaking Constantinople's walls, he hopes to provoke a response from Rome. These presumed twin pillars of orthodoxy, he argues, must join their efforts to defend themselves against those threatening to invade their cities and supplant their positions of power.

As he constructs this alliance, John simultaneously makes it clear that a rivalry exists between this new Rome and Alexandria and, therefore, between their bishops. While Innocent is a confidant and a like-minded citizen of Rome, John marks Theophilus as an outsider, and a jealous one at that. To make his case, John states that Theophilus completely undermines the laws of the fathers (tous nomous tonn paterōn) that dictate appropriate behavior toward fellow bishops. He goes against "the laws and the canons and all regular procedure" set out at both the councils of Nicaea and Constantinople, and his behavior has largely to do with why he arrived in Constantinople in the first place. John argues that the Alexandrian bishop was

33. Translation: Neil McLynn, "Two Romes, Beacons of the Whole World: Canonizing Constantinople," in Two Romes: Rome and Constantinople in Late Antiquity, ed. Lucy Grig and Gavin Kelly (Oxford: Oxford University Press, 2012), 345. McLynn resists the presumption that this canon may have been set in an effort to dissuade the overreaching influences of Alexandria as well as promote the standing of Constantinople as the capital chosen by Theodosius as a beacon of orthodoxy. That said, the letter does appear to note a standing rivalry between the two cities. 
initially summoned by the pious emperor (ho eusebestatos basileus) to answer for charges of misconduct. Although John does not elucidate the charges here, he is presumably referring to Theophilus's foul treatment of the Nitrian monks, who were expelled from Egypt at the early stages of the Origenist controversy.

As the Origenist controversy began to heat up, and Theophilus started to feel pressure from his Jerusalem counterparts, he confronted the Nitrian monks to correct their theological leanings. The scene quickly turned violent. Theophilus was repeatedly noted for his irascible temper, a detail mentioned by several biographers. After refusing Theophilus's entreaties to curb their heretical ways, the socalled Tall Brothers were reportedly beaten by the bishop and chased out of Egypt. They fled to more friendly allies across the empire and made their way to Constantinople. They were taken in by both the empress Eudoxia and John Chrysostom upon their arrival.

John only alludes to the aftermath of this controversy, but he does stress that Theophilus was commanded to come to Constantinople to account for his behavior, and to come alone. He was called as a defendant, not an equal. Theophilus ignored even this simple request. Instead of humbly entering that great city, Theophilus brought a contingency of Egyptian supporters as if "to show from the outset that he came for war and conflict" (Ep. 7, 2.8). ${ }^{34}$ His offensive tactic was confirmed by his ongoing militant behavior. The Alexandrian bishop stubbornly rebuffed all of John's attempts at hospitality. He then blatantly refused to reside within the city limits of Constantinople. John states that Theophilus settled outside the polis (exō pou tès poleōs), as if laying siege to Constantinople. While alarmed by these decisions, John still hoped that the two men might come to a civil resolution and bring an end to this uncomfortable affair. When John was further urged by the emperor "to go outside the walls to the place where Theophilus was sojourning, and hear the argument against him" (Ep. 7, 2.9), John reluctantly obeyed. He insisted that he never sought to condemn Theophilus, but dutifully left the sanctity of the city to parley with the hostile outsider.

The situation only escalated from there. It appears that Theophilus did not come empty handed but carried with him certain documents that were meant to undermine John's authority and eventually threatened his position. John implies that these documents contained key canons laid out at the council of Nicaea when he says, "For we had too much respect for the laws of our Fathers" (tous nomous tōn paterōn) $(E p .7,2.9)$. Since we know the outcome of the tense situation, it is believed that John was referring specifically to canons 5 and 6 . Canon 5 states:

34. "Synagagōn meth' heautou plēthos Aigyptiōn ouk oligōn paraginetai, kathaper ek prooimiōn deixai boulomenos, hoti eis polemon kai parataxin aphikneitai." Edition: PG 47 2.8. Translation: Robert T. Meyer (ed. and trans.), Palladius: Dialogue on the Life of St. John Chrysostom, ACW 45 (New York: Newman, 1985) in consultation with PG 47 2.8-12. 
Concerning those, whether of the clergy or the laity, who have been excommunicated, the sentence is to be respected by the bishops of each province, according to the canon that forbids those expelled by some to be admitted by others. But let an inquiry be held to ascertain whether anyone has been expelled from the community because of pettiness or quarrelsomeness or any such ill nature on the part of the bishop. (Emphasis mine) $)^{35}$

If we are to believe that these letters include the quoted canon, the message was loud and clear: Theophilus's decision to expel the Nitrian monks was none of John's business. Canon 6 also reaffirmed the Alexandrian bishop's autonomy: "The ancient customs of Egypt, Libya, and Pentapolis shall be maintained, according to which the bishop of Alexandria has authority over all these places, since a similar custom exists with reference to the bishop of Rome. Similarly in Antioch and the other provinces the prerogatives of the churches are to be preserved" (emphasis mine). ${ }^{36}$ These letters (grammata) Theophilus carries with him lay out the terms of a bishop's rights outside of his episcopacy. All charges made against a bishop, however grievous, were to be contained within the borders of his episcopal see. Ironically, this privilege of autonomy was one that Theophilus would ultimately deny John.

Soon after this confrontation, Theophilus began to gather evidence against John and initiated a campaign to oust the bishop of Constantinople. John states that Theophilus "seduced" the citizens of Constantinople, "as if the church were already widowed, and had no bishop" (Ep. 7, 2.9). Theophilus then went a step further, brazenly accusing John of lawlessness and even soliciting the assistance of known enemies of John to further condemn him. The bishop of Constantinople, not Alexandria, was now on trial. Aghast at his boldness, John reminded Innocent that it was Theophilus, not John, who was accused of misconduct.

John insisted that Theophilus's brazen decision to act the judge was completely absurd and evidence of his illegal activity against both John and, more importantly, the church. He continued, "He had not yet received the charges against us, yet from the very beginning he had cut himself off from the church and communion

35. Translation based on the standard Latin text in Giuseppe Alberigo, et al. (eds.), Conciliorum Oecumenicorum Generaliumque Decreta, critical edition, vol. 1, The Oecumenical Councils from Nicaea I to Nicaea II (325-787), Corpus Christianorum (Turnhout: Brepols, 2006). Canons 5 and 6 of the Nicene document of 318 are subsequently violated. Canon 5 continues: "Accordingly, in order that there may be proper opportunity for inquiry into the matter, it is agreed that it would be well for synods to be held each year in each province twice a year, so that these inquiries may be conducted by all the bishops of the province assembled together, and in this way by general agreement those who have offended against their own bishop may be recognized by all to be reasonably excommunicated, until all the bishops in common may decide to pronounce a more lenient sentence on these persons. The synods shall be held at the following times: one before Lent, so that, all pettiness being set aside, the gift offered to God may be unblemished; the second after the season of autumn."

36. This statement might also refer to canon 3 from the council of Constantinople in 381 , which I will address shortly. 
and prayer, and he was even bribing our accusers. He transferred the clergy and emptied the churches; how could he rightly mount the judge's bench which in no way belonged to him?" (Ep. 7, 2.9). Not only is Theophilus's reputation called into question, but his presumption as an outsider exacerbates the situation even more. Theophilus was no member of the Constantinopolitan community-an argument reminiscent of Athanasius's charges against his Cappadocian competitors. By what right, John exclaimed, could Theophilus even begin to presume to judge its citizens or its bishop? The audacity of the situation leads John to exclaim, "Nor was it even fitting for one from Egypt to act as judge in Thrace, considering that he was answerable for charges and was an enemy [echthron] and hostile [polemion] besides" (Ep. 7, 2.9). Theophilus was the outsider. He was the enemy. And he dared to mount charges against John.

To add insult to injury, Theophilus arraigned a synod to remove John from his bishopric. The illegality of this act was due in no small part to the fact that John was not there to defend himself. ${ }^{37}$ Under the right circumstances, John argued, he would have happily defended himself before his accusers. The arguments of Athanasius in Defense before Constantius (34-35) echo in the background. Theophilus's actions, however, are illegal (para thesmon) and undermine accepted canons (kanona) and customary procedures (akolouthian). But they were successful, and John was sent into exile in 403. Now he was the outsider just beyond Constantinople's walls.

To contrast these two scenarios still more, John goes on to compare his own forced removal (ekbalen) from Constantinople with Theophilus's flight back to Alexandria. First, we learn that John was seized in the dead of night and placed on a ship against his will. Theophilus's departure from the city also took place at night and on a ship but was done in secret (lathra ... apedra): "Theophilus secretly at midnight flung himself into a boat, and so made his escape, taking all his company with him" (Ep. 7, 2.9)..$^{38}$ One man was forcefully and illegally removed, while the other fled willingly. John then pauses to remind Innocent that Theophilus still has not stood trial for his crimes. After his flight, Theophilus was commanded by

37. Again John shames his opponent, stating that the heathens would not have acted so callously: "Not even in the heathen courts would such audacious deeds ever have been committed, or rather not even in a barbarian court, neither Scythians, nor Sarmatians would ever have judged a cause in this fashion, deciding it after hearing one side only, in the absence of the accused, who only deprecated enmity, not a trial of his case, who was ready to call any number of judges, asserting himself to be innocent and able to clear himself of the charges in the face of the world, and prove himself guiltless in every respect" (John Chrysostom, Ep. 7, 2.12). Not unlike Athanasius, Apol. Const., the theme of absence plays a significant role in this letter (see chapter 1).

38. “[Theophilus] lathra meson nyktōn eis hakation heauton hembalōn, houtōs apedra, meth' heautou pantas epagomenos." 
the emperor to return for his trial, but he refused to return, and John remained a condemned man.

These parallel stories were meant to highlight the stark difference between the two men. On the one hand, we have a bishop who would gladly have appeared to defend himself before a lawful court, but after an illegal trial, he was forced from the city deep in the night. On the other hand, we have a warring bishop who not only refused to answer for his crimes but also fled into the night like a coward. The two men could not be more different, and their flights reveal who the real guilty party was in this unfortunate situation.

John closes the letter with a brief description of the devastation that resulted in the aftermath of Theophilus's departure and John's expulsion from the city. The oft-quoted scene of the invasion of Hagia Sophia, mentioned only briefly in this letter but greatly detailed in Palladius's account, foreshadows what would happen if John were not restored to his see. It was as if all of Constantinople experienced exile. John concludes, "the whole city moved outside the walls" (Ep. 7, 2.9). ${ }^{39}$ Once again, like John's mentor, Meletius, a bishop carries the city with him into exile.

These calamities affect not only the faithful, according to John, but all the citizens of Constantinople, including its heretics, Jews, and Greeks. ${ }^{40}$ In a curious statement, John paints for us a dark image of what took place and what would happen if Innocent fails to take action:

For the trouble has not been confined to Constantinople but has extended into the east. When some evil matter discharges from the head, all the limbs are corrupted; in the same way, now that the evil has begun in this great city, disorder has made its way everywhere, like water from a spring. Everywhere clergy are in revolt against bishops, and as for the lay congregations, some are split up into factions, others are likely to be so; everywhere we find the throes of evil, and the undoing of the whole world (Ep. 7, 2.8).

The picture painted by John was indeed alarming. If we expand our understanding of what was at stake-namely, John's position as the orthodox bishop of Constantinople-we find the makings of a quite unusual heresiology. On more than one occasion, Theophilus acted the part of a heretic, although he was never explicitly

39. "Pasa hē polis exō teicheōn metōkizeto." The concept of voluntary and involuntary flight during this tenuous moment is clearly under debate. John wants to assure his readers that his removal from Constantinople was completely against his will. Theophilus, on the other hand, skulks secretly out of the city; the image is not unfamiliar if one keeps in mind Athanasius's own departure from Alexandria.

40. "Ouch hoi homodoxoi monon, alla kai hoi hairetikoi kai Ioudaioi kai Ellēnes" (Ep. 7, 2.11). This is a significant break with John's construction of these groups in his Antiochene homilies. See the discussion of how John constructs the Greeks and Jews as others in Shepardson, "Controlling Contested Spaces," 483-85; and Sandwell, Religious Identity, 88. 
charged. He was labeled hostile and an open enemy of both Constantinople and the church. John even states that he severed himself from the church. If those accusations are not enough, John demonstrates how he violated the laws of the fathers (tous nomous tōn paterōn) (Ep. 7, 2.9). If we follow John's logic and draw attention to how Christian flight was used in this text, it becomes clear that John's enemy has no right to the office of the bishop or even to be called a Christian. To state it another way, John insists on several occasions that the pious emperor urged him to pursue this lawless figure to administer judgment. Theophilus first undermined John's authority in violation of the very same canons he brought with him to keep John out of Alexandrian affairs. He went on to accuse John of crimes he never committed and against which he was not present to defend himself. Theophilus then solicited the help of common criminals whom John had cast out of his community before fleeing from that holy city after the damage had been done.

After reading this letter, it is clear that Theophilus's violation of the Nicene canons - the very ones he brought to ensure his own authority-and his repeated attempts to undermine John's authority put him in a position that was questionable at best. And, according to John, his illegal activities and involvement in John's forceful removal call into question Theophilus's claims to orthodoxy. While John did not explicitly call Theophilus a heretic, John's biographers certainly would, and it is clear why. We will return to Theophilus when we examine John's biographical afterlife in the next chapter. For now, it is enough to say that the events that transpired placed Alexandria and its bishop into a contentious relationship with Constantinople and its bishop. The battle is one we have heard before and one will hear again.

\section{BISHOPS WHO DO NOT RETURN}

As we saw in the previous chapter, the growing importance of Constantinople brought with it a series of challenges that would make John's attempts at control a trepidatious one at best. This becomes all the clearer when we consider that John's problems were equally, if not more, problematic inside the city as they were without. His interactions with the court in Constantinople, for instance, were anything but placid. Many scholars follow the lead of John's ancient biographers and take particular note of his tempestuous interactions with the empress Eudoxia. ${ }^{41}$ But these often overexaggerated accounts of their relationship are suspect. Mayer has made a clear case for why and how Eudoxia's memory was strategically maligned. ${ }^{42}$

41. Socrates, Eccl. Hist. 6.18.1-5 makes a case for the enmity that arises between Chrysostom and Eudoxia.

42. Wendy Mayer, "Doing Violence to the Image of an Empress: The Destruction of Eudoxia's Reputation," in Violence in Late Antiquity: Perceptions and Practices, ed. H. A. Drake (Aldershot, UK: Ashgate, 2006), 205-13. For discussion of the significant role Eudoxia's death in childbirth plays in 
In addition to John's tense imperial relationships, his ties to the urban ascetic community in Constantinople and the surrounding area were also strained. Unlike Athanasius, John was frequently at odds with the monastic community due to his intense reform efforts. Clark has noted that John's early condemnation of subintroductae - a practice of spiritual marriage in which celibate men and women lived together-was particularly unpopular. ${ }^{43}$ John's disdain for the influential ascetic Isaac, whom Kelly identifies as the "founder of monasticism in the capital," also did not win him any friends. ${ }^{44}$ John's brief tenure as the reigning bishop of Constantinople was just as difficult to defend inside its walls as it was from the outside.

John's efforts to transform Constantinople into a distinctly Christian city brought its own set of conflicts, as Nathaniel Andrade has convincingly argued. This was due to John's controversial insistence that it was the bishop who made the city holy. ${ }^{45}$ Andrade further gleans from John's homilies images of a heavenly politeia present in the very structures of an urban reality. John therefore engaged in yet another battle, this time within the city itself, to take on those imperial ceremonies that elicited the sights, smells, and noises of its lingering pagan past:

Such imperial ceremonies drew individuals into a material context of vision, hearing, and scent that deprived them of the agency to act and speak morally as they became coerced by demons, overwhelmed with sinful desires, and mired in relationships that challenged the integrity of Christian bonds. In this way, John emphasized the materiality of imperial ceremonies in civic spaces and claimed that they prohibited the acts of individual moral agency necessary for the creation of a Christian community. ${ }^{46}$

John's response was to degrade potent sites of imperial self-aggrandizement, such as the hippodrome, monuments, and statues. We hear of John carrying out his own processions and even introducing new saints to the city in an effort to strip away the power of competing symbols. By filling the city streets with prayers and psalms, John wrested away a pagan past and replaced it with a distinctly Christian future. ${ }^{47}$ Yet this battle would also be lost once John was cast into exile not once, but twice. And if we follow his conclusions from his letter to Innocent and keep with his logic in his praise of Meletius, it is clear that he, too, intended to take the city with him after he was expelled.

Ps.-Martyrius's recovery of the legacy of John Chrysostom as an unquestionably orthodox figure, see Barry, "Diagnosing Orthodoxy."

43. Elizabeth A. Clark, "John Chrysostom and the 'Subintroductae," Church History 46, no. 2 (1977): 171-85.

44. Kelly, Golden Mouth, 124.

45. Nathaniel Andrade, "The Processions of John Chrysostom and the Contested Spaces of Constantinople," Journal of Early Christian Studies 18, no. 2 (2010): 161-89.

46. Ibid., 166.

47. Andrade (ibid.) points to the literary work of Ps.-Martyrius as an example of how this literary transformation crystallizes in John's afterlife, a topic to which we will return in the next chapter. 
While in exile, John looked for other strategies to continue his fight for the city as its one true patron. A total of around 242 surviving letters written by John between 404 and 407 demonstrate this point..$^{48}$ Mayer has thoroughly examined John's effort to exploit the patron-client relationships he built while in Constantinople and relied upon throughout his life as an exile:49

John was not as isolated as he claims (he instead had a number of clergy at his service throughout the three years of his exile), it also now becomes clear that being isolated from the services of individuals of the rank of bishop for the role of envoy was a significant component of the penalty of exile. Because his access was restricted to lesserranked clergy (presbyters and deacons) to fulfill this role, the effectiveness of that portion of John's correspondence aimed at achieving rehabilitation was from the beginning compromised, with the potential of effecting the opposite result to that intended..$^{50}$

His use of these political envoys and his reliance upon previously established networks helped to ensure that his authority would still be felt in the city even if this epistolary campaign failed to secure his return. Despite his compromised position, John never ceased to believe that he was the legitimate bishop of Constantinople. These letters also reveal the evolution of John's exilic identity once it is clear that his appeals to Innocent would not result in his return.

Mayer traces the various exilic personae that John used to elicit sympathy and help from his supporters. He made ample use of classical tropes to achieve his "exilic agenda." ${ }_{11}$ And he altered the content of each letter to bend the persona of exile to his advantage. In other words, his representation of his own condition while in exile shifts depending upon the recipient of his letter. Epistle 173, for example, is a letter to Evethius, a presumed member of a noble family and among one of many supporters in Caesarea..$^{52}$ In this letter, his exile is described as

48. See Roland Delmaire, "Les "lettres d'exil" de Jean Chrysostome. Études de chronologie et de prosopographie," Recherches Augustiniennes 25 (1991): 72-180. Delmaire has provided a helpful reconstruction of the dating and delivery of these works, as well as a synopsis of the contents of each letter. A more recent article on the history of the letter collection is Daniel Washburn, "The Letter Collection of John Chrysostom," in Late Antique Letter Collections: A Critical Introduction and Reference Guide, ed. Cristiana Sogno, Bradley K. Storin, and Edward J. Watts (Oakland: University of California Press, 2016), 190-204. The total number of letters also depends on how one calculates those found in various manuscript traditions. For a discussion of the different groupings and reception of the letters, see Washburn, "Letter Collection," 192-93.

49. For the collected translation, see Wendy Mayer and Pauline Allen, John Chrysostom (London: Routledge, 2000), which builds upon the exhaustive efforts made by Delmaire. For more on this collection, see also Wendy Mayer, "John Chrysostom: Deconstructing the Construction of Exile," Theologische Zeitschrift 62, no. 2 (2006): 248-58.

50. Mayer, "John Chrysostom as Crisis Manager," 134.

51. Mayer, "John Chrysostom: Deconstructing the Construction of Exile," 250.

52. Delmaire states that Evethius was a member of noble family that aided John throughout his exile and dates this letter to September 404. The family lived in either Cappadocia or Galatia. See Delmaire, "Les "lettres d'exil," 125. 
a peaceful retreat, even a welcome break from the demands of life in the city. John remarks that he is "delighting in the quiet of the countryside and the freedom from politics" (Ep. 173.711-12)..$^{53}$

In a series of letters written in November 404 to affluent individuals in Constantinople, John again presented his authority as if it were firmly in place. ${ }^{54}$ For example, he used his authority to encourage and even reproach the behavior of certain members of his former community. He consoled Studius, who has lost a family member (Ep. 197). He accused Theophilus and Salustius of neglecting their duties and avoiding attending prayers (Ep. 212). And in the summer of 405, John used flattery and bold address to connect with Gemellius, the newly elected prefect of Constantinople (Ep. 124). Even though John was removed from Constantinople, he constructed his persona as a pastor and ecclesial leader still heavily invested in the community.

His tone shifted dramatically in his correspondence with Olympias, his chief benefactress in Constantinople. ${ }^{55}$ Olympias is the direct recipient of seventeen letters from John. ${ }^{56}$ In one letter we find a remarkably charged lament over the harsh conditions and desolate terrain in which John has found himself (Ep. 6). Contrary to the peaceful ascetic retreat he described in the earlier letter to Evethius and in subsequent letters to other Caesarian supporters, John here detailed the hardships and terrors he had to face along the way to his destination. And he did so again in another letter that addresses the horrors of his current state (Ep. 61).

The marked contrasts between these letter collections signal to Mayer an intentional use of familiar exilic tropes to interpret his condition in exile. Comparisons could easily be made to Ovid, for example, whose exilic identity easily slips between lament and ease. John's approach, unlike Ovid's, relies on philosophical commitments to take life's hardships in stride. In his letters to the Caesarean community, for example, he reasserted his stature and authority as a bishop who is quite capable of finding beauty in any circumstance. And we see in John's letters to Olympias how his use of consolatory themes is meant to demonstrate how his suffering strengthens him and refines his character. But each self-presentation is used to reinforce his authority. We see in these various collections how John presented himself in different ways: In one set, he is a man of leisure taking advantage of his circumstances, much like Athanasius. In another set, he is merely a temporarily displaced pastor who still directs his community

53. "Entruphōntes tē hēsychia tou chōriou, kai tē apragmosynē." Edition: PG 52.711-712. Translation mine. Mayer adds that this letter is one of many addressed to the Caesarean community that supported John; see Mayer, "John Chrysostom: Deconstructing the Construction of an Exile," 255-57. The other Caesarean letters include Ep. 80-84 (Edition: PG 52, 651-53e) and Ep. 172 (Edition: PG 52 710).

54. John Chrysostom, Ep. 117, 197, 212, 217, and 220.

55. John Chrysostom, Ep. 6. Edition: SC 13, 126-27. A similar lament takes place in John Chrysostom, Ep. 236.

56. Wendy Mayer, "Constantinopolitan Women in Chrysostom's Circle," Vigiliae Christianae 53, no. 3 (1999): 265-88; and Elizabeth Clark, Jerome, Chrysostom, and Friends: Essays and Translations (New York: Mellen, 1982). 
in absentia. In still another, John describes himself as a victim of circumstance, who, despite the odds, is able to weather his hardship. Mayer concludes: "What emerges from the letters is a man totally focused on rehabilitation and on regaining control of the reins of a see from which, he believes, he has been wrongfully deposed. John writes as someone who is still, despite his physical distance, the Bishop of Constantinople." 57

Yet John does not return. After realizing that his status as an exile appears to be permanent, John's exilic persona takes on universalizing tones, which build on the consolatory themes present in his letters to Olympias. These themes overlap with popular discourses focused on universalizing the experience of exile to cultivate a philosophical life found in the Greek authors of the Second Sophistic..$^{5}$ It is clear that John combined classical works with biblical models of suffering while in exile as a way to recast his experience of displacement. Mayer also takes notice of this shift in letters composed at the end of his life:

In letters written directly to clergy and laity who were in prison, in hiding, or who were being harassed, John's approach is not to reassure them that he is doing everything possible to have them released or the persecution terminated, but to commend them for their endurance and the love for him this demonstrates. In essence, he counsels them to bear their sufferings nobly, since they are doing it for orthodoxy and for God, and to comfort themselves with the knowledge that their persecutors will draw down upon themselves their own punishment. ${ }^{59}$

It is in his treatises No Man Can Be Harmed and To Those Who Are Tempted that John fully developed his exilic discourse and finally departed from earlier notions that focused on a theory of return. To add credence to his claims, these two treatises lay out not only the terms for John's experience but also the tenets of his version of the Christian life. To be a true Christian, John concludes, is to accept a life filled with perpetual suffering and, more importantly, displacement.

57. Mayer, "John Chrysostom: Deconstructing the Construction of an Exile," 257.

58. See, e.g., Favorinus of Arelate, On Exile, whose reflections intentionally blur the lines between an imagined and literal exile. See Whitmarsh, "Greece in the World," 290. Whitmarsh states that the historian is left wondering whether Favorinus was actually exiled by the emperor Hadrian or whether it was his literary practice that placed him in that position. In either case, Favorinus's reflections function as a political commentary that stresses cosmopolitanism rather than genealogy as the source of one's identity. In other words, Favorinus envisions exile as a universal condition. As Simon Goldhill points out, Greekness was an identity adopted by both Roman and Greek authors living under Roman rule and proved to be a powerful trope that elite authors used to identify themselves as the civic elite. Although Favorinus is still a Greek in the Roman Empire, he uses his circumstance "to authorize and empower himself as a writer and orator in the present." Goldhill, Being Greek under Rome: Cultural Identity, the Second Sophistic and the Development of Empire (Cambridge: Cambridge University Press, 2007), 178.

59. Wendy Mayer, "The Bishop as Crisis Manager: An Exploration of Early Fifth-Century Episcopal Strategy," in Studies of Religion and Politics in the Early Christian Centuries, ed. David Luckensmeyer and Pauline Allen, Early Christian Studies 13 (Strathfield, Australia: St Paul's, 2010), 163. 
No Man Can Be Harmed and To Those Who Are Tempted were written during the last two to three years of John's life (ca. 406-407).$^{60}$ Both texts are apologetic treatises and were addressed to Olympias. In the first, No Man Can Be Harmed, we find a dialogue on the nature of human suffering. The proem asks us to imagine John standing before a universal court. He boldly appears before his accusernamely, public opinion-as a representative of God's providence. (Here we may have a reimagined trial at the Synod of the Oak.) John's goal in this text is to refute the claims of public opinion that many are unjustly injured. Unmerited suffering, they argue, undermines the providential nature of God. John countered this argument by asserting that no man is capable of injury that he has not already inflicted upon himself.

John presented this philosophical dictum as being particularly true for the Christian philosopher. In many ways, his logic follows that of Seneca the Younger (1-65), who was exiled to Corsica by Claudius in 41. During his exile, Seneca wrote his three treatises titled Consolations, in which he addressed the theme of a universalized exile. Like John's, his concern was suffering. In No Man Can Be Harmed, John appears to have come across similar conclusions as Seneca, as both state that external forms of suffering are incapable of harming the wise man. Seneca addresses this topic in Consolations 2:

"What then?" you say; "will there be no one who will attempt to do the wise man injury?" Yes, the attempt will be made, but the injury will not reach him. For the distance which separates him from contact with his inferiors is so great that no baneful force can extend its power all the way to him. Even when the mighty, exalted by authority and powerful in the support of their servitors, strive to injure him, all their assaults on wisdom will fall as short of their mark as do the missiles shot on high by bowstring or catapult, which though they leap beyond our vision, yet curve downwards this side of heaven. ${ }^{61}$

Although Margaret Amy Schatkin has argued that John's link to Seneca is often misunderstood as what she termed a "pseudo-Stoic" principle, there do remain overlapping conclusions. ${ }^{62}$ Whether John favors one philosophical principle over

6o. The full title of the first treatise is No Man Can Be Harmed Who Does Not Harm Himself (Quod nemo laeditur nisi a se ipso), which I shorten here for the sake of brevity. Edition: SC 103. Translation mine in consultation with the French and NPNF1 9. It is clear that the text is written prior to To Those Who Are Tempted as it is referenced in two sections of that text. Edition: SC 79. Translation is mine in consultation with the French.

61. Seneca, Dial. 2. Edition: LCL 214. Seneca also refers to Ovid's poetry of exile. For direct evidence linking the two authors, see John Gahan, "Seneca, Ovid, and Exile," Classical World 78, no. 3 (1985): 145-47.

62. Margaret Amy Schatkin, John Chrysostom as Apologist (Thessaloniki: Hidryma Patriarchikon Paterikon Meleton, 1987), 90. Schatkin states, "Though this dictum circulated as a Stoic paradox in the time of Seneca, who wrote a diatribe on it, its origin is not Stoic but Socratic." She emphasizes that there is a stronger link to the Socratic principle-to do injustice is a greater evil than to suffer 
another is not important for our purposes here. What is clear is that John appealed to a variety of philosophical voices to reconcile and rearticulate his condition as a permanent exile. In No Man Can Be Harmed, we no longer hear the urgency of return or the paternalistic demands of a pastor temporarily removed from his flock. The intertextual links that weave throughout this work instead reveal how John attempts to locate and defend a universalized understanding of the exilic state. ${ }^{63}$

It is notable that John frequently cited exile as a primary example of what others might deem unmerited suffering. For example, as an exile one is robbed of one's possessions, suffers the loss of one's status, and is forced to live beyond the boundaries (hyperorios) of one's homeland. Upon reflection, however, John deemed these supposed losses as lacking merit. He began by describing the destructive nature of wealth. It does not provide pleasure, it does not create honor, and it does not bring power. To illustrate, he compared and contrasted biblical figures such as Job, Lazarus, and Judas. ${ }^{64}$ Despite their seemingly lamentable experiences of suffering, Job and Lazarus avoid blasphemy and subsequently attain eternal glory. ${ }^{65}$ Judas, on the other hand, greedily chooses blasphemy and falls into eternal disrepute, with a messy outcome. John concluded that each individual is responsible for his own destiny.

Pushing the point still further, John rounded out his argument by examining two biblical accounts. ${ }^{66} \mathrm{He}$ compared the story of those Jews who remain in their homeland (ho Ioudaion demos) with that of three children who were exiled. The Jews who stayed in their homeland brought on all sorts of calamity, whereas the "virtue of the three children" (tèn aretèn tōn paidōn tōn triōn) who lost their homeland (patridos apobolē) remained intact as they stood up to the barbarians and the Persian king. ${ }^{67}$ The children, of course, win the glory of victory over hardship. John emphasized this point by stating that the children neither shared in the luxuries of home nor even had access to the comforts of the familiar, yet, despite every hardship they faced in a foreign land as exiles, they maintained their stalwart natures. As in John's sermon on Meletius, it is their condition of exile that confirms their virtue and not their failure.

The theme of suffering is again taken up in the second and last treatise, To Those Who Are Tempted, which was composed chiefly for his supporters in

an injustice-than to pseudo-Stoic leanings. Yet many Stoic themes resonate with the work of Seneca the Younger.

63. John outlines his case first through theoretical proofs (chaps. 2-11), then through historical proofs (chaps. 12-17), and finally through an epilogue that sums up his conclusions.

64. See John Chrysostom, No Man Can Be Harmed, chapters 4-10.

65. Job is not only cast out (ekballo) of his city, but he also makes his home in the "dunghill" (kopria).

66. These accounts are found in Daniel 3.

67. It is unclear whether or not John counts these children as Jews. It appears their faithfulness and courage contrast significantly with the so-called Jews who stay in their homeland. 
Constantinople. ${ }^{68}$ The text addresses several key themes: the cause of scandal, which is doubt in the providence of God; the remedy, which includes both scripture and external experience; the nature of suffering, which is a summation of his earlier treatise; and the benefits of suffering, which includes a discussion of exile. Finally, in typical apologetic form, John offers a description of the rewards that will be given to the faithful and the retributive acts of the divine that will be inflicted upon sinners. ${ }^{69}$

This particular consolatory text makes ample use of exilic topoi to describe the nature of suffering as a universal experience that is not determined by one's spatial location. Instead, regardless of where one is, suffering ultimately takes place within oneself. Suffering is an internal battle that must be conquered in order to master the self. The suffering of the just must ultimately be explained. And it is through the claim that suffering is an instructive tool that teaches moderation and humility. In other words, suffering is beneficial.

John is no longer a defendant on trial. Instead, he depicts himself as the physician who prescribes a universal cure for all those tempted to succumb to despair. While he remains in one place, his logos, or discourse, is sent out in his place to heal and remedy the downtrodden. Schatkin again has drawn our attention to John's use of the Stoic principle regarding an unhealthy philosophical life that is overrun by pathos when logos is absent. The remedy then must be the importation of the logos. Schatkin states, "To cure the diseased soul, the Stoics, beginning with Chrysippus, employed a double method: prophylaxis and de facto cure."70 Correspondingly, this double prescription is made available through divine scripture and empirical experience.

Once again, John characterized exile as a universal condition by invoking key biblical exemplars. The wandering biblical figures surface in John's exploration of the benefits of suffering. In a startling appeal, he invoked the infamous Cain as his first example. The bloodthirsty brother, we are reminded, is one of the first to be condemned to a life of wandering. Links to the condemned man are reminiscent of that similarly unlikeable hero, Oedipus. Although both men are condemned to wander, they also wander with divine protection.

Next, we find the typical leaders of God's people, such as Abraham, Jacob, and Moses, who move from one place to another (apo topōn eis topous metēgage). These suffering men wander not because they are guilty, but because of their righteousness. These are divinely commanded wanderings. Their education, like that of Odysseus, comes from their travels. John contrasted these two literary

68. The text consists of a prologue, a description of the scandal (chaps. 2-4), a proposed remedy (chaps. 5-23), and an epilogue (chap. 24).

69. This last theme will resurface in our discussion of both Palladius's epilogue and Ps.-Martyrius's description of the empress Eudoxia's death.

70. Schatkin, John Chrysostom as Apologist, 124. 
motifs in order to universalize the Stoic principle that to suffer is to be human, regardless of whether one is guilty or innocent. All are exiles, because all souls must wander. How one makes use of this condition is what separates the Cains from the leaders of God's people.

The pinnacle event comes when God's Son is sent to wander the earth and ultimately suffer and die for the redemption of humanity. Here John's logic sounds very similar to Athanasius's in the Defense of His Flight. John, too, stressed that the Logos wandered. What is different in this wandering is that in the process of taking on the human condition, Jesus also healed this natural state. ${ }^{71}$ It is not enough to model oneself after this biblical link. John's logos has been sent out to heal, just like the divine Logos-even when he is unable to attend to his patients in person. Like the divine Logos, John's physical absence is replaced with the healing power of his words (logos). John then reassured his supporters that no harm would come to them that they did not create for themselves. Their particular form of suffering will pass if they only heed the words of his logos.

\section{CONCLUSION}

The circumstances surrounding John's exile enable us to realize that the borders John constructs are conceptual. They are fantasies-imagined realities-that help him to justify and re-narrate his own predicament. In his earlier works and letters, he constructs a narrative of the self, as well as of the borders of the city. As Denise Walker states, "our narratives of the self, both in casual conversation and in written autobiography, are dominated by narratives of place. Indeed, the generic imperative of autobiography to represent who we are is more often than not answered by the recollection of where we were." ${ }^{72}$ At first, John's desire was to preserve his legacy as a bishop intent on return. Throughout his epistolary efforts, he built an authoritative exilic persona that he then crystalized in two apologetic treatises composed at the end of his life. As we have seen, the legacy he built for himself changed when it became clear that John would not be reinstated as bishop, and he described exile instead as a universal condition. To do so, he appealed to familiar themes found in the classical conciliatory tradition. ${ }^{73}$ John's episcopal authority was thus affirmed precisely because he suffered as an exile. John's exilic discourse evolved over the course of his experience and ultimately crystalized as a universal position that all humans must experience. By keeping the end in mind, the individual experiences of suffering, exile chief among them, blur into the larger

71. Athanasius, Fug., also appeals to these familiar biblical tropes of flight, although they are used to justify his flight in times of persecution.

72. Denise Walker, "The Displaced Self: The Experience of Atopia and the Recollection of Place," Mosaic: A Journal for the Interdisciplinary Study of Literature 36, no. 1 (2003): 21-33.

73. See, in particular, Plutarch, Cons. ux. and Cons. Apoll.; Cicero, Tusc.; and Seneca, Marc. 
vision of a shared experience of wandering on this earth among the guilty and innocent alike. Some will wander in ignorance, and others-those willing to learn (and cure)-will wander with knowledge and without harm.

As Ruth Morello and A. D. Morrison have argued, letters helped ancient authors to negotiate social status and power relations as well as dramatize roles. ${ }^{74}$ This is certainly the case when we look at the variety of genres present in John Chrysostom's expansive epistolary campaign. In the Letter to Innocent I, John aligns Constantinople with Rome. He stresses that these two holy cities-and the bishops who appropriately reside within-are at risk when outsiders threaten to invade and undermine their authority. John describes what he sees as an assault. He focuses on the activities of Theophilus of Alexandria, who has unlawfully interfered in Constantinopolitan politics. Due to his heinous activity, John argues, the very sanctity of Constantinople, and possibly of other holy Roman cities, is under threat. Here we see jettisoned, once again, two significant imperial cities: Constantinople and Alexandria. Familiar appeals to themes of persecution and tacit charges of episcopal malfeasance frame this letter, as well as the Letter to Olympias.

When his appeals to Rome fail to secure a permanent return, John increases his epistolary efforts, and his exilic identities forged in the letter collection produced between 404 and 407 changes significantly. The letters in this second group are modeled on classical themes and include references to long suffering, indifference, and even descriptions of luxurious retreat. The aim in this second phase was to produce an authorial persona that justified his ongoing status as an exile. John's epistolary efforts perform what Owen Hodkinson has identified as a "macro-unit of composition" and what he sees as "a kind of literature in which the author can experiment with miniature correspondences, personas, chronological and thematic relations and intratextual allusion., 75

John was a masterful craftsman and appealed to a variety of literary models and themes to fashion his exilic self, but his efforts failed to secure his ultimate objective. He remained a bishop in exile with no end in sight. This outcome is seen most clearly in the two theological treatises composed for his most intimate correspondent, Olympias. In No Man Can Be Harmed and To Those Who Are Tempted, John argues that exile is the natural state of all humanity. His experience in exile might appear, at first sight, different-and maybe even suspicious. Quite to the contrary, he concludes: all Christians are in exile.

And while this definition of exile as wandering and the status of all Christians as wanderers was picked up by later Western exilic discourses, it remained

74. Ruth Morello and A. D. Morrison, eds., Ancient Letters: Classical and Late Antique Epistolography (Cambridge: Oxford University Press, 2007). Epistles also promoted what Morello and Morrison identify as a didactic mode: "In pursuing a didactic agenda, the letter genre becomes remarkably elastic, adapting and adopting features from almost any other genre for best effect" (ibid., $\mathrm{x}$ ).

75. Hodkinson, "Better Than Speech," 287. 
a troubling concept for those who attempted to dispel rumors of John's exile as evidence of his guilt. ${ }^{76}$ During his own lifetime and soon after his death, John's reputation was quickly discredited by associations that placed him in dangerous company. His storyline mirrors that of Cain or Oedipus more than the biblical patriarchs and Moses, or even Odysseus, with whom he would take common cause at the end of his life. John's biographers would not adopt this universalization of the exilic state as a paradigm. ${ }^{77}$ Much like his treatment of Meletius, John's own death outside of his episcopacy was not so easily dismissed. The biographies written by Palladius of Helenopolis and the so-called Ps.-Martyrius instead contain localized exilic discourses that elevate the significance of a bishop's position in the city. As we will come to see, this might explain why the dissenting voices of the anti-Johanite party are eventually drowned out. The bishop and his city, especially the city of Constantinople, proved to be much too powerful a picture of orthodoxy for even contemporary biographers to latch on to as a standard for evaluating John's exile. We now turn to see how John's story of exile was wrapped into yet another heroic tale of wandering. We will once again ask ourselves: What does Alexandria have to do with Constantinople?

76. Scholars at the International Medieval Congress at the University of Leeds in 2002 examined the different forms exile took during the Middle Ages from ca. 900 to ca. 1300 in western Europe; the results are published in Laura Napran and Elizabeth van Houts, eds., Exile in the Middle Ages (Turnhout: International Medieval Research, 2004). The second half of the volume focuses on exile in an ecclesiastical context as it is linked to new interpretations of Christian identity.

77. Palladius does invoke themes of earthly detachment that crop up in these two treatises, but the state of universalized exile is not extended to all who suffer. The uniqueness of John's exile is the only thing that reveals his status as the rightful and true heir to the Constantinopolitan see. Palladius also seems to adopt John's use of Plutarch's notion of the delay of divine punishment evident in To Those Who Are Tempted and in his letters to Olympias (see, e.g., Ep. 7). 


\section{4 \\ To Rehabilitate and Return a Bishop in Flight}

Having thoroughly investigated every form of slander and wickedness and having discovered that all <their efforts $>$ were being overcome by the truth, they sought refuge in the illegal laws of the Arians and with them plotted evil concerning the saint [John], copying < the Arians'> madness concerning the blessed Athanasius [concerning his return].

-PS.-MARTYRIUS, FUNERARY SPEECH FOR JOHN CHRYSOSTOM ${ }^{1}$

The forty bishops who held communion with Arius had legislated that "if any bishop or any priest who had been deposed, justly or unjustly, should reenter his church on his own initiative, without permission of a synod, such a one shall have no opportunity of defense, but shall be absolutely excluded." Now that canon was declared null and void as being illegal and passed by illegal persons....

-PAlladius, Dialogue on the life of JOHN CHRYSOSTOM ${ }^{2}$

As we have come to see throughout this book, the reputation of a bishop was often determined and solidified in the works of his defenders. But whose message should we trust? Is it that of the naysayers, who condemn any man in flight? As Tertullian had remarked, a man who flees persecution is clearly at fault. Or is it the word of those who properly reorder and orient our understanding of the events surrounding an orthodox flight the more trustworthy of voices? A temporary exile could be explained away as long as the man in flight returned triumphant. And yet some exiles never return. What are we to make of the man suspended in flight?

1. Ps.-Martyrius, Fun. Orat. 99. Edition: M. Wallraff (ed.) and C. Ricci (trans.), Ps.-Martyrius, Oratio funebris in laudem sancti Iohannis Chrysostomi: epitaffio attribuito a Martirio di Antiochia (BHG 871, CPG 6517), Quaderni della Rivista di bizantinistica 12 (Spoleto: Fondazione Centro italiano di studi sull'Alto Medioevo, 2007). Translation: T. D. Barnes and George Bevan, The Funerary Speech for John Chrysostom, Translated Texts for Historians 60 (Liverpool: Liverpool University Press, 2013), with slight alterations for clarity marked here by brackets, unless otherwise noted.

2. Palladius, Dia. 9. Edition: SC 341-42. Translations mine. 
We are left to conclude that the memory-making exercise and its intersection with exilic discourse was a fraught process, particularly when the very terms of exile appeared to shift, as we saw in John Chrysostom's reflections on his status as an exile in the previous chapter. John, that failed bishop of Constantinople, did not return triumphant. His defenders, who sought to recover John's reputation, and whose work we will explore in this chapter, were left with a new and difficult challenge: how do they recover the reputation of their hero when his death appeared to confirm his guilt? Even John's finals words on the subject of exile threatened to undermine his earlier, and more defensible, thoughts on the subject.

As we explored, John Chrysostom's exilic discourse transitioned from a local to a universal one as it became clear that he would not return triumphant but would die a condemned man. It is rare to find biographies, ancient or contemporary, that emphasize this point. Instead, John's biographers continued to proclaim him as a defender of the faith and an unquestionably orthodox father of the church. They did not ignore his exile, but they did make clear that John died a victim of circumstance and assured their readers that he was not a heretic. We have an unusual abundance of evidence regarding the circumstances of John's expulsion from Constantinople, yet the details contained in both his own account and the accounts offered by his biographers provoke more questions than they answer. ${ }^{3}$ Again, we must ask: whose word should we trust? If words fail, John's biographers argue, then the spaces of orthodoxy must prove the innocence of the man in flight.

In this chapter, I will show how two ancient biographers, the so-called Ps.Martyrius and Palladius of Helenopolis, offer significantly altered versions of the events leading up to and during John's exile from Constantinople. His defenders did not invoke their hero's final vision of a universalized exile but instead drew their readers back to the space he was first exiled from. They made Constantinople once again a central focus for the promotion and restoration of John's afterlife, much as Gregory of Nazianzus did with Athanasius's legacy. According to John's biographers, it is clear that the reasons for his exile were tied directly to his status as a symbol of Christian truth in a theologically infused space. For Ps.-Martyrius and Palladius, what was at stake in how they told the story was not just John's legacy but also the legacy of Constantinople and its orthodoxy. And it is their version of the events that influenced how later pro-Nicene authors would remember John and his two exiles.

To accomplish this goal, we will concern ourselves with how both of John's biographers localize his exile as they begin to sort out the heretics from the orthodox. As many scholars have noted, John was not only embroiled in the Trinitarian controversies surrounding Arianism, but he also found himself similarly intertwined with the growing Origenist controversies of the later fourth and early fifth 
centuries. ${ }^{4}$ His reputation as a bishop became the intense focus of a Johanite faction in and around Constantinople soon after his death. John's orthodoxy was called into question precisely because he died while in exile. Finally, we conclude with an examination of how John's memory was revived and returned to the recognizably orthodox space of Constantinople.

As we will see, John must be returned to that glowing city of Nicene orthodoxy. Yet, as the two epitaphs that open this chapter point out, the return was as challenging to retell as the removal itself. John's posthumous return must therefore be tied to another return, and the biographers accomplish this by invoking the legacy of Athanasius, bringing it into the city of Constantinople, even if by seemingly conflicting routes. John Chrysostom and Athanasius of Alexandria both embody a complex history of Christian flight that must be reconciled within the boundaries of Constantine's, and later Theodosius's, city of Christian orthodoxy.

\section{HOW TO DIAGNOSE EXILE: PS.-MARTYRIUS'S FUNERARY SPEECH}

The lesser-known Ps.-Martyrius provides yet another example of how Christian flight and heresiological discourse travel within the orthodox project. In his Funerary Speech, Ps.-Martyrius attempts to transform John into a martyr and a saint. The speech was written around 407 by an unnamed supporter of John and focuses primarily on the events leading up to John's expulsion from Constantinople. ${ }^{5}$ Similar in style to Gregory of Nazianzus's panegyric on Athanasius of Alexandria, the Funerary Speech includes the details of John's early life but emphasizes his exile in order to laud John's efforts to promote and preserve orthodoxy. For example, John's involvement in the Gainas affair plays a definitive role in the early sections of this account. ${ }^{6}$ Gainas, a Gothic general commanding troops in and around Constantinople, appealed to the emperor Arcadius in an effort to secure the right to worship inside of the city limits. Although more well known elsewhere as a "barbarian," Ps.-Martyrius's text describes Gainas as an Arian bent on invading

4. For a comprehensive evaluation of the Origenist controversy, see Clark, Origenist Controversy. For a recent examination of Palladius's involvement in the controversy as it pertains to his Dialogue, see Katos, Palladius of Helenopolis.

5. See T. D. Barnes, “The Funerary Speech for John Chrysostom (BHG3 $871=$ CPG 6517)," Studia Patristica 37 (2001): 328-45. Barnes argues that the author is a deacon by the name of Cosmas, although this argument is contested, and the pseudonym Ps.-Martyrius remains the key identifier of the author. Wallraff and Ricci argue the author is Philip of Side; see Wallraff and Ricci, Ps.-Martyrius, 27n11. The structure of the text is carefully dissected by Florent van Ommeslaeghe, "De lijkrede voor Johannes Chrysostomus toegschreven aan Martyrius van Antiochie: Tekstuitgave met commentaar, hoofdstukken uit de historische kritiek" (PhD diss., Katholieke Universiteit te Leuven, 1974); and van Ommeslaeghe, "La fête de S. Jean Chrysostome dans l'église grecque," Analecta Bollandiana 96 (1978): 38.

6. The account is also mentioned in Socrates, Eccl. Hist. 8.7, and Sozomen, Eccl. Hist. 6.5. 
and overtaking the city. John successfully convinces Arcadius to refuse Gainas, and this is described as a decisive win for Nicene orthodoxy (Fun. Orat. 24-26).

Although often apologetic in nature, the bulk of the speech serves as an invective against John's two chief enemies: Theophilus of Alexandria and the empress Eudoxia. Ps.-Martyrius characterizes Theophilus as a villainous and irascible patriarch. What he takes issue with is not Theophilus's orthodoxy but his political activities, which Ps.-Martyrius saw as dishonoring his role as a bishop. Elm states, "The Theophilus portrayed by Ps.-Martyrius is not a likeable character either, but rather than the abject villain portrayed by Palladius, we find here a man who was a shrewd politician and excellent power-broker, quick to forge and dissolve alliances without being overtly impeded by scruples." 7 Ps.-Martyrius highlights Theophilus's violent treatment of the Tall Brothers, for example, but the Origenist controversy is clearly not his chief concern.

The role of chief opponent and heretical threat in this text is instead reserved for the imperial matriarch. T. D. Barnes addresses Ps.-Martyrius's choice of an imperial literary foil, noting that a standard schema is used to describe rulers who persecute the faithful: the persecutor is afflicted by a painful illness, worms consume him, and then, in pain, he acknowledges his error and is permitted to die. ${ }^{8}$ The deaths of Antiochus IV of Syria (2 Macc 9:5-28) and King Herod Agrippa serve as popular models within Jewish texts. For example, in Flavius Josephus's Jewish War, we find a detailed description of Herod's untimely end:

After this, the distemper seized upon his whole body, and greatly disordered all its parts with various symptoms; for there was a gentle fever upon him, an intolerable itching over all the surface of his body, continual pains in his colon ... and a putrefaction of his privy member, that produced worms ... when he sat upright, and had a convulsion of all his members. ... The diviners said those diseases were a punishment upon him for what he had done to the Rabbins. ${ }^{9}$

Elizabeth Castelli draws attention to the use of this literary schema in later Christian invectives. ${ }^{10}$ Gruesome medical conditions are a frequent form of fantastical retribution in Lactantius's Death of the Persecutors, in which, for example, Galerius, like the infamous Nero, sets fire to the city and blames it on the Christians; a painful gastrointestinal disease is the consequence of this poor choice. Lactantius described for his readers how the cancerous ulcer slowly rots away the emperor's intestines: "As the marrow was assailed, the infection was forced inwards, and got hold of his internal organs; worms were born inside him. The smell pervaded not

7. Elm, "Dog," 76.

8. Barnes, "Funerary Speech," 336.

9. Flavius Josephus's Jewish War 1.656. Translation: William Whiston, The Works of Flavius Josephus: Complete and Unabridged (Peabody, MA: Hendrickson, 1989), 596.

10. Elizabeth Castelli, "Religious Identity through the Prism of Spectacle in Early Christianity" (paper presented at the Symposium on Identity in Late Antiquity, Duke University, February 20, 2009). 
just the palace but the whole city; and this was not surprising, since the channels for his urine and excrement were now confused with each other. He was consumed by worms, and his body dissolved and rotted amid insupportable pain" (Mort. 33.6-8). ${ }^{11}$ The pain was so excruciating, Lactantius reported, that it compelled him to cry out to God, saying "that he would restore the temple of God and make satisfaction for his crime" (Mort. 33.11). It was only after he kept Christians from further persecution that his disease finally eased into death. Lactantius carefully dissected the body of the persecutor to display before his readers the internal corruption of the tyrant. Each detail penetrates the reader's senses: we hear the guilty cry out, we smell the bodily decay, and we see their insides burst forth in a display of their guilt.

Retributive schemas and vivid depictions of human suffering and gore such as these surface in heresiological texts later in the fourth century as well. As Ellen Muehlberger has noted, Arius's illness and death were frequently commented upon. ${ }^{12}$ In his Letter to Serapion concerning the Death of Arius, Athanasius of Alexandria invoked execrable images similar to those engaged by Lactantius. Only moments before Arius is supposed to be received back into communion with the church, Athanasius gleefully reported, "a wonderful and extraordinary circumstance took place.... Arius, who had great confidence in Eusebius and his fellows, and talked very wildly, [was] urged by the necessities of nature [and] withdrew, and suddenly, in the language of Scripture, 'falling headlong he burst open in the midst,' and immediately expired as he lay, and was deprived both of communion and of his life together."13 The phrase "burst open" (elakēsen) links Arius to the death of Judas Iscariot in Acts 1:18, which reads, "Now this man [Judas] obtained a field with the reward for his wickedness, and falling headlong, his body burst open and all his intestines gushed out." Both Arius and Judas Iscariot are deprived of mercy, and their bodies are unable to contain the error within them, so their corrupted bodies are cut off from communion with the church.

It was popular after the second half of the fifth century to imagine heresy as a disease. ${ }^{14}$ These Christian etiologies of heresy proved to be an effective means

11. Edition: SC 39, 115. Translation: J. L. Creed (ed. and trans.), Lactantius, De Mortibus Persecutorum, Oxford Early Christian Texts (Oxford: Clarendon, 1984).

12. See Ellen Muehlberger, “The Legend of Arius' Death: Imagination, Space, and Filth in Late Ancient Historiography," Past and Present 277 (2015): 8-10. Muehlberger traces how the story of Arius's death is co-opted into different ancient historiographical projects from the 360 on. The details of how and where Arius dies shift in order to meet the needs of different Christian authors. For example, she compares the emphasis on the exposure of Arius's shame in a public toilet in Rufinus, Eccl. Hist. 10.14, with the added spectacle of his death out in the open, near the porphyry column, in Socrates, Eccl. Hist. 1.38.7.

13. Athanasius, Ep. mort. Ar. 3. Edition: Hans-Georg Opitz (ed.), Athanasius Werke 2, Band 1, Erster Teil: Die Apologien (Lfg. 1-7) (Berlin: de Gruyter, 1940), 178-80. Arius's death is also reported in Socrates, Eccl. Hist. 2.38. Epiphanius also describes Arius's death with reference to Judas, see his Pan. 68.6.9.

14. See, e.g., John Rufus, Plerophories, 26, 40, 65. An earlier link between the rhetoric of psychagogy in philosophical traditions and medical imagery in New Testament texts treats diseased souls and 
of identifying the impious and reimagining how the enemies of God were punished. ${ }^{15}$ By overlapping the medical with the theological, Christian authors also helped their readers to distinguish the guilty from the innocent. This growing trend took a troubling turn once the pregnant body of a persecuting empress became the target of Christian invective. Ps.-Martyrius's description of Eudoxia's punishment for her involvement in John's two exiles makes this link all the clearer.

Eudoxia remains an infamous character within Christian memory, as Wendy Mayer has noted. ${ }^{16}$ Her involvement in John's first exile is not detailed in this text, but one presumes the empress is at least complicit with the imperial strength used to ensure John's initial departure from the city. It is only from other biographical sketches that we learn more about her particular influence. The fifth-century historians Socrates and Sozomen, for instance, claim that Eudoxia called for John's second exile after an inflammatory sermon he gave chastising the empress. ${ }^{17}$ According to later Byzantine vitae, however, it was John's criticism of her effort to confiscate a poor widow's vineyard that prompted the empress's actions, which clearly link her to Jezebel. ${ }^{18}$ Barnes and Bevan have recently suggested that the strife between the empress and John actually arose from John's sharp critique of imperial politics, especially as they related to the treatment and subsequent execution of the powerful eunuch Eutropius in $399 .{ }^{19}$

appears to underline much of what Christian authors view as the corruptive nature of heresy; see A. Malherbe, "Medical Imagery in the Pastoral Epistles," in Texts and Testaments: Critical Essays on the Bible and Early Church Fathers in Honor of Stuart Dickson Currie, ed. W. Eugene March (San Antonio, TX: Trinity University Press, 1980), 19-35; and M. Nussbaum, "Therapeutic Arguments: Epicurus and Aristotle," in The Norms of Nature: Studies in Hellenistic Ethics, ed. M. Schofield and G. Striker (Cambridge: Cambridge University Press, 1986), 31-74.

15. For a discussion on the infection of worms in tyrants, see T. Africa, "Worms and the Death of Kings," Classical Antiquity 1, no. 1 (1982): 1-17. The most famous etiology of heresies is list of heresies and prescribed cures in Epiphanius of Salamis's Panarion. For a recent discussion of the overlap of heresy and disease, see P. Mena, "Insatiable Appetites: Epiphanius of Salamis and the Making of the Heretical Villain," Studia Patristica 67 (2013): 257-64; and R. Flower, "Genealogies of Unbelief: Epiphanius of Salamis and Heresiological Authority," in Unclassical Traditions, volume 2: Perspectives from East and West in Late Antiquity, ed. Christopher Kelly, Richard Flower, and Michael Stuart Williams (Cambridge: Cambridge Philological Society, 2011), 70-87.

16. Mayer, "Doing Violence." Eudoxia's reputation is often marred by her perceived involvement in John's exile. See also Mayer, "Constantinopolitan Women."

17. Socrates equated Eudoxia with the infamous Herodias in Mark and Matthew's gospel. He exclaimed: "Herodias rages madly again, dances again and again seeks to receive the head of John on a platter" (Socrates, Eccl. Hist. 6.18.1-6). Ps.-Martyrius, however, favored the equally slanderous Jezebel. Sozomen, Eccl. Hist. 8.16, 20, contain his records of the ill-fated speeches.

18. K. G. Holum, Theodosian Empresses: Women and Imperial Dominion in Late Antiquity (Berkeley: University of California Press, 1982), 48-78. The link to Jezebel is discussed further below.

19. See Barnes and Bevan, Funerary Speech, xi. They go on to argue that this criticism appears to have put him at odds with the royal couple to such an extent that Arcadius and Eudoxia have their son, Theodosius, baptized by Severianus of Gabala, as a public sign of their rejection of John's authority; 
Although Arcadius could easily have also played the role of persecuting despot in the Funerary Speech, Ps.-Martyrius focused almost exclusively on Eudoxia. It remains to be seen why he would favor an invective solely against the empress and not the emperor as well. Retributive literature frequently aligned punitive illness with male rulers. ${ }^{20}$ At first glance, we might assume that the woman with power was singled out because she fully embodied the role of the persecuting imperial figure. If we look closer, however, we see that her body contained a more grievous error and made her experience akin to the fate of Arius.

In a charged moment of the narration, John's first exile ends immediately after Eudoxia's miscarriage:

I will not willingly hide the symbol of the Lord's anger at what was done ... knowing that the root of all evil had been concealed [tès kakias apasēs hè rhiza apokekryptai] in the woman who exercised power, [he then] released his hand. The arrow flew and hit the stomach of the wretched woman, reminding her and saying: "Woman, in pain will you give birth to children" [Genesis 3.16], sending them forth from your stomach straight to the grave, mixing with the first swaddling clothes the final burial shroud and becoming in one instant both a mother and childless. (Ps.-Martyrius, Fun. Orat. 66 $)^{21}$

This striking passage reveals several details about John's imperial enemy. First, the body of the empress is the explicit target of God's anger. Her husband is not to blame, and neither is the Alexandrian bishop Theophilus-at least not yet. Second, the arrow strikes her body and instantly kills the root of all evil within her. ${ }^{22}$ And,

later pro-Johanite sources omit this event entirely. The link to children appears to support the message conveyed in this account. See note 24 below on the death of Jezebel's children.

20. The notable exception is found in a much older source: Herodotus's Histories. He references the death of the queen of Cyrene, Pheretime, whom the gods punish with a comparable disease because she used excessive force against her enemies, impaling the chief instigators of her son's murder and cutting off the breasts of their wives. Herodotus notes, "Pheretime ... died an evil death, having become suddenly full of worms while yet alive; for, as it seems, too severe punishments inflicted by men prove displeasing to the gods" (Herodotus, Hist. 4.205). As we will soon see, Eudoxia’s body was also overcome with worms.

21. The translation here has been altered for reasons I explain in greater detail below in note 32. I translate gastros as "womb," but the most common terms in medical literature are mêtra, "womb," or hystera, "uterus." If we follow the retributive literature from which this text is drawing, then gastros should be translated as "belly" or "stomach." Barnes and Bevan translate this term as "stomach" in other passages in the text, which I explore in detail later in this chapter.

22. Ps.-Martyrius here appeals to the classical trope of poisoned arrows from the gods. Divine beings were known to use poisoned arrows as punishment. Poisoned arrows are also an ambivalent symbol. They kill off many monsters in Greek myth, but they also injure innocent bystanders: e.g., the death of the centaurs Chiron and Pholus (Ps.-Apollodorus, Biblio. 2.83-87). It appears that even the most powerful heroes and villains are vulnerable to poisonous arrows. The most famous example is Heracles, who kills with poisonous arrows and is himself killed by one (indirectly). For a popularized version of his death, see Ovid, Metam. 9.134-272, and Her. 9. 
finally, the episode ends with a damning reference to Eve's curse. This revealing biblical link emphasizes that the empress's body is predisposed to error, a frequent claim regarding both women and heretics. Nosological treatises also consistently stress that the constitution of the patient determines a proper diagnosis. ${ }^{23}$ Both biological and external factors must be taken into account to read the disease. In this instance, Eudoxia's cursed body and the poisoned arrow results in a painful and deadly disease that kills the evil growing inside her.

Ps.-Martyrius makes use of other typological links as well. He frequently refers to Eudoxia as Jezebel (Ps.-Martyrius, Fun. Orat. 3; 6; 138), the infamous matriarch of the Northern Kingdom who exiles the prophet Elijah (1 Kgs 19). ${ }^{24}$ This second biblical link further supports the idea that Eudoxia promoted competitive Christian factions in and around Constantinople. ${ }^{25}$ Readers attuned to the biblical narrative might recall that Jezebel's first son, Jehoram, died from an arrow wound (2 Kgs 9:19-21). The comparison was clearly not lost on Ps.-Martyrius. ${ }^{26}$

The Funerary Speech also evokes classical myths. The myth of Niobe, the queen of Thebes, would have been familiar to Ps.-Martyrius's readers. Ovid, for example, recounted how Niobe's taunting of the goddess Leto draws the wrath of the gods. Her children are subsequently hunted down and killed by the poisoned arrows of Leto's children, Apollo and Artemis. ${ }^{27}$ Both the hubris of nefarious women and the original mother's curse place Eudoxia within a long line of deviant mothers, as well as persecuting despots.

After she miscarries (and is sufficiently humbled), Eudoxia immediately calls for John's return. She even attempts to personally reinstate him as the bishop of

23. The Hippocratic author of Airs, Waters, Places, for instance, emphasizes the role that the constitution of the sufferer plays in diagnosis (Hippocrates, Aer. 9). According to Ps.-Martyrius, this predisposition appears to be the case with women, all of whom fall under the curse of Eve, which is discussed in later detail in this chapter.

24. Jezebel was a more threatening power than her husband, Ahab, and promoted the worship of the god Baal. For a discussion on Jezebel's afterlife, see T. Pippin, "Jezebel Re-Vamped," in A Feminist Companion to Samuel and Kings, ed. A. Brenner, Feminist Companion to the Bible (Sheffield, UK: Sheffield Academic, 1994), 196-206. For a description of the gendered pairing, see P. Trible, "The Odd Couple: Elijah and Jezebel," in Out of the Garden: Women Writers on the Bible, ed. C. Büchmann and C. Spiegel (New York: Ballantine, 1994), 166-79. Eudoxia's second miscarriage might also be linked to Jezebel's daughter, Athalia, who was married to the corrupt king of the Southern Kingdom, Jehoram (n.b., this Jehoram is not the same as Jezebel's first son, also named Jehoram). Athalia is also described as corrupt ruler, but it is her husband, Jehoram, who dies from a disease of the bowels. The disease described mirrors Eudoxia's second miscarriage. Like Eudoxia's, his bowels are painfully expelled from his body (2 Chron 21:19-21). While Jezebel's progeny die as adults, there may be a loose allusion here to Eudoxia's supposed culpability as the mother of whores.

25. The empress's alliances with the bishop Arsacius (d. 405) and his successor, Atticus (d. 423), John's rivals, are frequently remarked upon throughout the text.

26. Mayer, "Doing Violence," 206-8.

27. See, e.g., Ovid, Metam. 6.146-312. These arrows were particularly deadly and resulted in a swift death. 
Constantinople. Yet John, Ps.-Martyrius insists, would not willingly take back his see without the consent of a council; readers are reminded that the empire does not hold any jurisdiction in matters of faith. It is only after an unnamed council clears John of Theophilus's false charges that he agrees to return to his bishopric. ${ }^{28}$

Yet John's return is only temporary. Ps.-Martyrius reports, "He [the Devil] caused the woman who wielded power to forget the earlier blow and introduced in its place a deep hatred, which was without any trouble, planting many lies through many mouths" (Fun. Orat. 4, emphasis mine). As forgetfulness sets in and the many lies take root in what would be her last pregnancy, the empress calls for John's last exile. For a final time, then, John leaves Constantinople, and, as Ps.-Martyrius narrates, the entire city suffers as a consequence. Bereft of its true father, the church is burned, and, as Nathaniel Andrade has noted, all spiritual life departed from the city along with the bishop. ${ }^{29}$

With the city ablaze, fatherless, and devoid of spirituality, Ps.-Martyrius turns his gaze once again to the fecund mother and says, "another arrow of the Lord again hit the woman, no longer saying 'in pain,' but 'in death, woman, shall you bear children' [Genesis 3.16]" (Ps.-Martyrius, Fun. Orat. 121). Eve's story is once again read through the body of the empress, but the root of evil is replaced with a horrific monstrosity. Unlike her previous crime, for which she was justly punished, this final pregnancy is significantly different. It is no longer the simple pride of a monarch or the stain of Eve's disobedience that gestates within her, but an all-consuming excrescence that must be pierced by another arrow. But this second arrow releases a powerful disease. Ps.-Martyrius remarks, "[The arrow] loosed against her a painful and many-headed illness [nosma polykephalos] that virtually spoke: 'This is the finger of God'" (Fun. Orat. 121). The arrow that strikes Eudoxia in the first instance kills the root of evil growing within her. This second attack lets loose a disease that devours her from the inside out. What Eudoxia carries within her is much more dangerous than before.

In order to reveal the growing monster within and the epic battle waged by this disease, Ps.-Martyrius draws us into a detailed and elaborate account of Eudoxia's suffering:

28. John is once again removed from his position on the grounds that a second council could not be lawfully adjudicated after an initial deposition was been made. Ps.-Martyrius cites a law instituted after Athanasius's deposition thought to be carried over with Theophilus from Alexandria. Canon 5 from the Council of Nicaea states, "Concerning those, whether of the clergy or the laity, who have been excommunicated, the sentence is to be respected by the bishops of each province, according to the canon that forbids those expelled by some to be admitted by others. But let an inquiry be held to ascertain whether anyone has been expelled from the community because of pettiness or quarrelsomeness or any such ill nature on the part of the bishop." Edition: Alberigo et al., Conciliorum Oecumenicorum Generaliumque Decreta, and PG 47 2.9. Translation mine.

29. Nathaniel Andrade, "The Processions of John Chrysostom and the Contested Spaces of Constantinople," Journal of Early Christian Studies 18, no. 2 (2010): 161-89. 
See: there was a dead fetus in her, buried in its mother's cavities, which, by blocking the passage of foods, turned what was recently ingested in nauseous bile and forced the bitter fluid to rush back up to her throat, and thrust what had long lain dead downwards by the weight of the body with a great rushing. Next, as may be expected to happen with a dead body, floods of worms teemed forth, some quivering on top of the head of the unseen corpse and causing vomiting of the undigested food; others under its feet making the flux of the belly sharper and painful; and some, on occasion, creeping out with the mass of blood flowing forth. In addition, a fever seized the whole of the rest of her body, so close to fire that it shone, and all sleep, as you know, shuns the eyes of the delirious (Fun. Orat. 121). ${ }^{30}$

Eudoxia's stomach is flooded with the most nauseating of concoctions. As this glimpse into the birthing chamber shows, her torment follows a familiar pattern to the stomach ailments of those persecuting emperors before her: her intestines [along with her child] rot, spewing forth worms; sharp pains overcome her; and her body is racked by a fever. Like her male predecessors, she is fully conscious of every stage of her torment.

What stands out in this section of the speech is that Ps.-Martyrius avoids any description of gynecological disease..$^{31}$ The Greek term for "womb" is absent from both descriptions of Eudoxia's body being struck by the arrows of God. We are certainly aware that she is pregnant, because the outcome of each strike is described as a miscarriage. But Ps-Martyrius favors the more generic term gastros, "stomach, belly" to describe the target..$^{32}$ Particularly in this second scene, Ps.-Martyrius

30. I have altered the translation by Barnes and Bevan to more accurately convey the ambiguous nature of the fetus and what Ps.-Martyrius suggests is actually rooted within Eudoxia's body. If Ps.-Martyrius is using medical theory related to fetal development, the fetus has no independent agency until at least the eighth month of pregnancy; see A. E. Hanson, "The Gradualist View of Fetal Development," in Lembryon: formation et animation; antiqué grecque et latine tradition he'braï, chrétienne et islamique, ed. L. Brisson, M.-H. Congourdeau, and J.-L. Solère (Paris: Librairie Philosophique, 2008), 96-97.

31. For a discussion on different gynecological diseases related to the womb, see C. Faraone, "Magi$\mathrm{cal}$ and Medical Approaches to the Wandering Womb in the Ancient Greek World," Classical Antiquity 30, no. 1 (2011): 1-32. There is quite a bit of discussion in the Hippocratic corpus and medical literature at large (from Plato to the more contemporaneous doctors of late antiquity) on the relationship between the "wandering womb" and the "sacred disease." Faraone (3) argues that the wandering womb provokes diseases: the "womb was not the site of disease but rather the cause of spasmodic disease in other areas of the body." As many have argued, male and female bodies are often divided and treated separately within ancient medical literature. A series of gynecological texts was created to account for this difference. The Hippocratic corpus devotes an entire treatise to these particular gendered issues; see H. King, Hippocrates' Women: Reading the Female Body in Ancient Greece (New York: Routledge, 1998), 21-39; and the translation and introduction to the Diseases of Women by A. E. Hanson, "Hippocrates: 'Diseases of Women 1,'” Signs 1, no. 2 (1975): 567-84.

32. This term does have a semantic range that includes "womb." It appears that the choice made by Barnes and Bevan to translate gastèr as such is tied to their understanding of John's interactions with Eudoxia and her children; see Barnes and Bevan, Funerary Speech, 25-28, sections 8.1 and 8.2. Ps.-Martyrius's contemporaries also compare the empress to Jezebel. 
intentionally distances Eudoxia from her sex and queers her gender to fit her within the long line of persecuting emperors. ${ }^{33}$ The disease that pierces and takes over her body is a gastrointestinal one that places her firmly within the retributive tradition. ${ }^{34}$ For our purposes, it is worth noting that according to various medical texts, these diseases not only frequently result in horrific pain and are troublesome to treat, but they are also extremely difficult to diagnose, because they remain hidden from view. ${ }^{35}$

While it is clear that Ps.-Martyrius makes full use of the retributive tradition, a few notable differences do stand out. ${ }^{36}$ We are reminded of the reason for Eudoxia's excessive torment. When she cries out in pain in this second scene, she calls out not to God, but to John: "Why do you attack me, John?" Her suffering is thus tied directly to the suffering of the exiled bishop. This connection to John's experience-and, as we will soon learn, his reputation-requires the divine to take matters into his own hands.

Ps.-Martyrius again relies on classical tropes to explain why such a disease is required to punish Eudoxia: it is what she carries that makes her such a dangerous threat. The description of the battle that takes place within her recalls the second labor of Heracles, in which he defeats the many-headed serpent, the Lernean hydra. ${ }^{37}$ After shooting flaming arrows at the beast, Heracles grabbed the hydra

33. Another queering takes place when John and his rival are compared to the two mothers in $1 \mathrm{Kgs} 3: 16-28$. John cares for his child(ren) and is characterized as the true mother who proved her (his) legitimacy when she (he) willingly handed over her (his) child in order to save it from being cut into two. See Ps.-Martyrius, Fun. Orat. 128-29.

34. Stomach ailments are particularly notable in ancient medical literature. Discussions pepper the Hippocratic corpus; see, e.g., Hippocrates, Aer. 7 and Acut. 17. These diseases are also particularly prevalent throughout Pliny, Nat. For his discussion on various diseases and treatments, see esp. Pliny, Nat. 30.19-23.

35. Nosological treatises, such as the Hippocratic Sacred Disease and Acute Diseases, place a particular import on the need for careful diagnosis, especially when the effects of the diseases are not visible.

36. This includes John Chrysostom's narration of exploding bodies and other texts such as the death of Julius Julianus, the uncle of Julian the Apostate, in his martyrology on St. Babylas. I will discuss St. Babylas in more detail in the next chapter. This foolish man unwisely decided to first touch the relics with a defiled hand then decided sit on the remains of the martyr. John writes, "Immediately, he paid the penalty for this unlawful session: his genitals became putrefied and generated worms. That the disease was sent by God is shown by this fact: when physicians killed luscious rare birds and placed them next to the putrefied members to elicit the worms, they did not emerge but clung tenaciously to the rotten parts, and he perished after many days" (Bab. 92). Edition: SC 362, 90-274. Translation: Margaret Amy Schatkin and Paul W. Harkins (trans.), Saint John Chrysostom: Apologist, FC 73 (Washington DC: Catholic University of America Press, 1983).

37. Several references to the second labor of Heracles circulated in and around Constantinople; see Diodorus Siculus, Hist. 4.11.5; Ps.-Apollodorus, Biblio. 2.77-80; and Ovid, Metam. 9.69 ff. As he proves throughout the course of his twelve labors, Heracles is the ultimate slayer of monsters. His cult was widespread in late antiquity. The tragedy Herakles, for example, composed by Euripides and then later adapted by Seneca as the Hercules Furens, was frequently performed in the theaters and depicted in the material culture of Constantinople. For the performance of material culture, see Ismene 
as it wrapped itself around his foot. As Hercules chopped off each of the hydra's heads, multiple regenerated heads would appear in its place, making the hydra a difficult monster to defeat. To prevent regrowth, Heracles has his companion, Iolaos, burn the sinews of each neck..$^{38}$ When the beast is finally defeated, Heracles dips his arrows into the venomous blood of the monster. In later labors, he uses the arrows to defeat his enemies. A simple touch of the arrow results in a burning sickness that attacks the body and lets off a putrid smell. ${ }^{39}$ Ps.-Martyrius, certainly familiar with this popular tragedy, weaves in several narrative strands to describe the war waged within Eudoxia. The many-headed lies growing within the empress required a many-headed illness to kill it. Similar themes such as the hero's hand, the burning fever, and the putrid smells invoke familiar visceral, literary links in Ps.-Martyrius's description of Eudoxia's bedroom struggle.

Ps.-Martyrius also evokes this familiar story to reveal to his readers what has taken root in Eudoxia. The many-headed lies are tied to the circulating rumors of John's collusion with and protection of known heretics. Heresy as a disease-a description favored by John Chrysostom himself-is particularly pernicious, as it spreads quickly and is hard to kill. Other heresiologists, such as Epiphanius of Salamis, also describe heresy as a "many-shaped monstrosity" (Epiphanius, Pan. 30.1.1). ${ }^{40}$ To kill off even the rumor of heresy requires the drastic intervention of the divine. ${ }^{41}$ These rumors, or lies, gestate within the empress. Her very person

Lada-Richards, “'By Means of Performance’: Western Greek Mythological Vase-Paintings, Tragic 'Enrichment, and the Early Reception of Fifth-century Athenian Tragedy," Arion 17, no. 2 (2009): 99-166. For Seneca's interpretation of Heracles's madness, see Anna Lydia Motto and John R. Clark, "The Monster in Seneca's Hercules Furens," Classical Philology 89, no. 3 (1994): 269-72. Two statues of Heracles were believed to be present in the hippodrome in Constantinople; see Albrecht Berger, "Herakles and the Hippodrome of Constantinople," in Hippodrom/Atmeydani: İstanbul'un Tarih Sahnesi, ed. Brigitte Pitarakis (Istanbul: Pera Müzesi, 2010), 194-205. Later Byzantine hagiography (e.g., the Halkin (or Patmos)-Vita) would depict Constantine as a type of Heracles who defeats several trials at the court of Galerius; see Samuel Lieu and Dominic Montserrat (eds.), From Constantine to Julian: Pagan and Byzantine Views: A Source History (New York: Routledge, 1996), 102.

38. Heracles gains sole credit for the defeat of hydra in Euripides, Her. 154.

39. Ironically, Heracles is infected later with this same poison, and it is the cause of his own death; see Ps.-Apollodorus, Biblio. 2.157; Ovid, Metam. 9.129, 158. Two accounts use the story of centaur(s), who is shot by one of Heracles's arrows washed his poisoned wound in the Anigros. This story is used to explain why the river emits such a horrific odor; see Strabo, Geog. 8.3.19; and Pausanias, Descr. 5.5.9. The waters were also supposed to have healing powers, and many lepers came to be healed there, according to Strabo: "The baths here cure leprosy, leuke, and leichene"; see Duane Roller, The Geography of Strabo: An English Translation, with Introduction and Notes (Cambridge: Cambridge University Press, 2014), 348.

40. See Andrew Jacobs, Christ Circumcised: A Study in Early Christian History and Difference (Philadelphia: University of Pennsylvania Press, 2012), 105. Jacobs highlights this phrase found in Epiphanius's description of the Ebionite heresy.

41. Ps.-Martyrius is stepping outside of convention in several ways. This is a curious twist on the popular image of God as good physician. Here he introduces a retributive disease to cure the disease of heresy. It does not cure Eudoxia but is intended to heal the church (and restore John's reputation). To kill 
threatens to reproduce them and possibly create still more. What is even more remarkable is that, instead of finding care in the hands of a competent midwife, Eudoxia is pierced by the finger of God (daktylos theou) and suffers grievously.

Yet, Ps.-Martyrius disdainfully remarks, Eudoxia does not repent and die. Like the pharaoh of Exodus, her heart is hardened, and she makes no attempt to recall John from exile as she did before. Writhing in pain, she obstinately summons John's rival, Arsacius, to her bedside instead. Eudoxia brazenly receives the Eucharist and, Ps.-Martyrius exclaims, "this was the only sin she had not yet committed" (Fun. Orat. 121). Ps.-Martyrius then uses grotesque imagery to draw the reader's eye to what is typically hidden from view:

[Eudoxia] seized the infant, and she quickly vomited out her soul along with the communion. Still breathing and half-alive, she filled the sensory organs of those standing by her with an evil stench surpassing the plants of India and the flies of Persia, ... her suffering hinting at nothing else than that $<$ it $>$ had long been among the dead things. In this way she brought her life to a close. (Ps.-Martyrius, Fun. Orat. 121) ${ }^{42}$

The violence of this spectacle grabs our senses. We see the fetus clutched in her arms, we hear her vomit out both soul and Eucharist, and we smell the stench emanating from her belabored breaths and the decaying bodies. Ps.-Martyrius makes visible through Eudoxia's second miscarriage and in her postmiscarriage emesis the corruption of both the body and the soul. ${ }^{43}$ In her pursuit of the cleansing perfection of a deathbed absolution, she perfects her sinfulness. The only evidence of holiness is vomited out, and, like that most notorious heretic, Arius, Eudoxia is successfully cut off from the church.

These textual (and gendered) allusions made by Ps.-Martyrius, if we can assume they are indeed at play here, serve a similar purpose to those employed by Cyprian of Carthage. Sonja Anderson has recently shown how Cyprian made ample use of this violent bodily rejection of the Eucharist in his text The Lapsed to reveal what is often hidden. Her observations point to the functionality of the Eucharist as both judge and judgment. ${ }^{44}$ She highlights two sections in the text where lapsed

a disease with another disease is also an aberration in the medical tradition, although not without some support. See, e.g., the reference to hemorrhoids, which are said to cure melancholia, mania, and nephritic affections (Hippocrates, Aph. 4.11, 21). My thanks to Richard Flower for pointing out this reference.

42. "Kai toutōn ontōn en toutois ekeinē to brephos katelambane, tacheōs tē koinōnia synexemesasa tēn psychēn. tosautēs de eneplēse ta tōn parestēkotōn aithētēria dysōdias, empnous epi kai hypozōos ousa, hōste nikasthai kai ta Indias phyta kai tous Perikous myas hapasan te . . . ouden heteron tou pathous ainittomenou ē hoti palai en nekrois etynchane. kai houtō dē katalyei ton bion." (Wallraff and Ricci, Ps.-Martyrius, 523b-524b, with slight emendation).

43. Ps.-Martyrius may be gesturing here to John Chrysostom, Catech. illum. 2.2. Edition: PG 49. 233. This is a catechetical sermon in which he describes how the mouths of the wicked defile the Eucharist.

44. These observations were made by Sonja Anderson, "Discerning the Body in Cyprian's De Lapsis" (paper presented at the North American Patristics Conference, Chicago, May 27, 2017). Many thanks to her for allowing me access to this paper. 
Christian women, in particular, are administered the Eucharist but are unable to stomach the rite. In the first case, we hear about an infant who was left behind by her Christian parents during the height of the Christian persecutions. During their departure, the baby was exposed to food and drink meant for idols without the parents' knowledge. After they returned and recovered their child, they brought the corrupted infant to church. When she was forcibly given the elements, the baby could not hold anything down. Cyprian describes the scene as such: "The Eucharist could not remain in a body or a mouth that was defiled; the drink which had been sanctified by Our Lord's blood returned from the polluted stomach. So great is the power of the Lord, so sacred His majesty; under His light the hidden corners of darkness were laid bare, even secret crimes did not escape the priest of God" (Cyprian, Laps. 25).

Cyprian's second scenario involves a youthful woman who attempts to slip by unnoticed. It is not entirely clear what her crime may have been, but it appears Cyprian accuses her of being a false Christian, who, like the empress, is unable to hide her internal error. And the outcome of this crime was no less poisonous:

It was not food that she took so much as a sword against herself, and what she swallowed might have been some deadly poison entering her breast. After the first spasms, struggling for breath, she began to choke and, a victim now not of the persecution but of her own crime, she collapsed in tremors and convulsions. The guilt which she had tried to hide did not remain long unpunished or concealed. If she had deceived man, she was made to feel the avenging hand of God. (Laps. 26) ${ }^{45}$

In Ps.-Martryius's Funerary Speech, the Eucharist functions as a revealer not only of duplicity, as in these examples from Cyprian, but also of heresy, even when Christian flight appears to place the blame upon those who flee. In the case of both Ps.-Martyrius and Cyprian, the author shifts our focus away from the true Christians in flight (read fleeing bishops) and back toward those who remain and try to pass as righteous. Only the hand of God or his physical presence in the elements proves otherwise.

This final scene in the Funerary Speech reveals that Eudoxia is not simply a persecuting empress, although she has certainly proven that she holds court among the most notorious of emperors. Her suffering in this second miscarriage mirrors the gastrointestinal diseases of her heinous imperial predecessors; her heretical counterpart, Arius; and even the duplicitous female members of Cyprian's lapsed community. Ps.-Martyrius concludes that what Eudoxia harbors is nothing short of a hidden war against the church (Fun. Orat. 122). Even more insidious for him is that error she houses within her body, an error which threatens John's legacy: the charge of heresy. She carries not a child but "the many lies spread through many mouths" (Fun. Orat. 4). It is a contagion of error that is initially hidden from view.

45. For a possible intertextual link, see my description of the trope of true martyr (Polycarp) versus the false martyr (Quintus), discussed in the prologue. 
We are made aware of its corrupting power only after the divine introduces the many-headed illness that consumes Eudoxia's body from the inside out and when her body physically rejects the Eucharist.

Ps.-Martyrius laments that the cause of Eudoxia's suffering is not readily apparent to the casual observer. We find this point reinforced by the inconsistent rumors surrounding John's death. One rumor stands out among the rest: John, too, dies of an unknown illness aggravated by his travels in exile. ${ }^{46}$ After news of the bishop's death spreads, Atticus-John's rival and Arsacius's replacement-dons the robes of bishop. He travels about the city attempting to win over those who had supported John and to ease the tensions that had arisen after his final exile. Ps.-Martyrius berates Atticus's efforts and calls him a false physician:

Tyrant ... with what objective in view do you apply medications to wounds that you have inflicted? Or, because you know how to flatter, did you deliberately cause pain before so that you might have an opportunity to practice your skill, acting exactly like a doctor who, having gathered countless herbs and fastened them with a rag, might carry this in his left hand, strike a man with a club in his right hand and say to him: "Cheer up, my dear friend, I have the remedy in my hands." (Fun. Orat. 137)

Here the medical mingles here with the theological once again. We find several arguments on the danger of false physicians in the Hippocratic corpus. Chief among the characteristics of false physicians is the intentional harm they cause their patients. ${ }^{47}$ It therefore remains unclear who the true impostor might be. John dies as an accused heretic in exile, while his rival walks free.

Ps.-Martyrius's exilic discourse is dependent upon the city-centered exilic discourse of John himself. Individual places in the city, such as the bedroom or the throne room, are transformed by those who inhabit them. The buildings and public gathering places are also miraculously changed by those given the authority to control them. The Gothic general Gainas is again an excellent example of the threat heresy posed to the citizens of Constantinople. His desire to use a church inside the city limits might infect all the other buildings in turn. Walls do not just make Christians; they make heretics as well, as Athanasius argued before. ${ }^{48}$

46. Ps.-Martyrius reports that his death was "brought about not by iron, but by what was much more cruel than iron-long forced marches and illness imposed on the natural frailty of the body" (Fun. Orat. 135). As Andrew Crislip has pointed out in his description of the saints Papias and Stephen, illness in the saints has symbolic value and invokes a certain element of ambivalence in hagiographers; see Crislip, Thorn in the Flesh: Illness and Sanctity in Late Ancient Christianity (Philadelphia: University of Pennsylvania Press, 2013), 17-18. Palladius (another of John's biographers) makes great use of illness in the saints in Laus. Hist. 12.3, 24.2; Crislip highlights Palladius's repeated discomfort with saints who fall ill and draws attention to John's homilies on the topic (Thorn, 182n2o).

47. Pliny rants against the lack of accountability in the profession, which he says is the only one in which killing another human being is permissible and without consequence (Nat. 29.8).

48. See chapter 1 . 
John's presence, as well as his eventual absence, also proves to be spatially transformative. Once again, we return to John's exilic discourse of the Christian experience. This time it is not a universalized vision that moves along with John but an atopia, a nonplace, that reveals the mobility of his orthodoxy:

The blessed Constantine long ago had made that space into a hippodrome before he founded the city. As a result it seems to me that it is owed to that man [John] that all his [Constantine's] works became churches, namely the colonnaded streets [stoai], the agora, the city, the baths, the hippodrome (when the holy father was present, all these places had been filled with prayers, but when he left for exile, they reverted to their previous status), and the church itself, which acquired the additional name and function of an agora. (Ps.-Martyrius, Fun. Orat. 97.7-16, emphasis mine) ${ }^{49}$

What stands out here is that exile, as an identity and as a condition, is a powerful discourse with which to construct oneself outside of a particular space, as Andrade has also emphasized. In this case, John's exile is thought to have brought an end to that vision of heaven on earth, so much so that once John is exiled from the pristine city, the spaces he transformed revert back to what they once were. Like Athanasius's city in the desert, we are left to wonder if it was just a mirage. But this is no Foucauldian reflection; it is a nonplace, an atopia, once the bishop flees.

As John Culbert has assessed, Roland Barthes links atopia, that which is unclassifiable, with the desire for the always-absent other. ${ }^{50}$ The city contains a palpable longing in the absence of the displaced bishop-or, for Ps.-Martyrius, the misplaced bishop. A bishop's absence is as significant as his presence, a claim we saw John make regarding Meletius in the previous chapter. His exile, therefore, becomes a desirable and powerful literary trope. John's legitimacy is preserved in the city. For Ps.-Martyrius, however, it is not the villains that substantiate this claim; it is ultimately the bishop's displacement that confirms John's orthodoxy. ${ }^{51}$ As a victim of persecution, he concludes, we are able to authenticate John's status as a purveyor of truth. Yet John's failure to return remains a significant problem. It takes the return of another story, another fleeing saint, to satisfy the longings of the city, but we must first look to another biographer, whose details of John's victimhood will eventually lead us - and John himself, by way of his biographersback to that golden city.

49. Translation: Andrade, "Processions," 162.

50. John Culbert, Paralyses: Literature, Travel, and Ethnography in French Modernity (Lincoln: University of Nebraska Press, 2010), 34 .

51. Theophilus plays a relatively minor role in this retelling of John's exile. There are many heretics in the text that tempt John and invade his episcopal space. In this particular account, however, Arian maniacs, pagans, barbarians, and even the heretic Origen himself enter the scene in order to substantiate John's power and identity as an orthodox leader. 


\section{HOW TO INTERPRET EXILE: PALLADIUS OF \\ HELENOPOLIS'S DIALOGUE ON THE LIFE \\ OF JOHN CHRYSOSTOM}

Palladius of Helenopolis (ca. 363-420) also constructs a localized vision of John's exile by foregrounding a dystopian image of the cityscape. His Dialogue on the Life of John Chrysostom is meant to rehabilitate John's legitimacy, as well as his own. Palladius appears to have composed his biography during his own exile in southern Egyptian city of Syene..$^{52}$ On the eve of John's second exile, we find not a description of partisan politics but a much bleaker vision of catastrophe and war. The city of Constantinople is invaded by an outsider, and the most unlikely of characters find themselves united: believers, heretics, Jews, and pagans all sympathize with one another over a common cause. The citizens of Constantinople unite and lament the calamity that led to John's expulsion from their most noble city. In that moment of crisis, we find a localized exilic discourse that sheds light on two descriptions of the aftermath of John's expulsion from that beacon of orthodoxy.

Written a year after John's death, Palladius's Dialogue (408) contains four sections: introduction (chaps. 1-4), narration (chaps. 5-11), argumentation (chaps. 12-19), and conclusion (chap. 20). ${ }^{53}$ The text unfolds in the interactive dialogue between a bishop from Constantinople and a deacon in Rome. The narrator, another delegate not unlike those in the introduction to John's letter, travels to defend John's orthodoxy and to clear his name.

Demetrios Katos, building on the work of Florent van Ommeslaeghe, offers a thorough examination of the Dialogue's value as a rich resource for understanding Palladius's involvement in the Johanite crisis. ${ }^{54}$ Many scholars look to Palladius's

52. See Peter Van Nuffelen, "Palladius and the Johannite Schism," Journal of Ecclesiastical History 64 (2013): 28n7. Van Nuffelen challenges the date of Palladius's exile given by both Edward Cuthbert Butler, The Lausiac History of Palladius (Cambridge: Cambridge University Press, 1898), 179-84; and Malingrey, Palladios, 18. Those scholars argue that Theophilus's death marks the turning point in the author's political career and initiates his return to Constantinople. Following the lead of Charles Pietri, Roma Christiana. Recherches sur l'Eglise de Rome, son organisation, sa politique, son idéologie de Miltiade à Sixte III (311440), 2 vols. (Rome: École Francaise, 1976), 1329, Van Nuffelen argues that an amnesty appears to have taken place while Theophilus was still alive and, after John's death and not the death of the Alexandrian bishop. As evidence, he points to passages that present a more tempered Palladius in the Dialogues and political policies that appear to have been put in motion such as those referenced in a letter to Theophilus from Synesius, the bishop of Ptolemais. While I do not agree with Van Nuffelen's reconstruction of a tempered Palladius, he convincingly argues that a major reason why Palladius could return while Theophilus was still alive is that no rivals to the Constantinopolitan see surfaced after John's death.

53. Katos argues that the text should be understood as a legal document that follows the principles of judicial rhetoric traceable to the Art of Political Speech attributed to Aspines of Gadara; see Katos, Palladius of Helenopolis, 46-52. There is an introduction (prooimion), narration (diēgēsis), argumentation (kataskeue), and conclusion (epilogos).

54. Katos, Palladius of Helenopolis. Also see Florent van Ommeslaeghe, "Que vaut le témoignage de Pallade sur le procès de s. Jean Chrysostome?” Analecta Bollandiana 95 (1977): 389-413. Van 
Lausiac History as more historically accurate and by far the most well known of Palladius's works. The Dialogue has also often been viewed either as a history or as a biography but hardly ever as both. Katos convincingly restores the historical value of the text by demonstrating all the traits of judicial rhetoric that make this work a legal defense and help us understand it as a bridge between the biographical and the historical.

The details of John's life, as well as the events that led up to his exile, are carefully crafted in the Dialogue. I depart from Katos's argument that this shift in rhetorical structure eclipses the emphasis upon Origenist controversy in the text. In addition to its use of judicial rhetoric, the text invokes an exilic discourse similar to what we find in Gregory of Nazianzus's panegyric on Athanasius of Alexandria. Like Gregory, Palladius uses episcopal exile to reinstate the authority and orthodoxy of an exiled bishop.

Palladius's introduction includes John's two letters to the bishop of Rome, Innocent I (Ep. 7 and Ep. 41), as well as Innocent's too-little-too-late response. Palladius, himself a traveling bishop, wandering far from the borders of Constantinople, builds on John's account in order to exonerate his hero's reputation. He does this by invoking the theme of justice as one of the basic characteristics of a utopian city. This politeia is balanced and just. All runs afoul, however, once the true and just bishop is removed from the city. Palladius begins:

The unfortunate East has suffered just as in the case of one who has paralyzed limbs realizes that vital forces make their way to the healthier parts of the body. With her limbs entirely paralyzed, the church is unable to function properly, since harmony has abandoned her. Most of us who are her champions and adherents make ourselves exiles from our own country, since we cannot live quietly and safely in our own land, as we love the truth. (Dia. 1, emphasis mine $)^{55}$

Just as John is exiled, so the rest of the church body is quartered and put to flight. As Palladius describes it, the church body is incapable of functioning properly without its bishop there to keep it all together.

Palladius fills in the details and takes great liberties with John's description of his departure from Constantinople. In this extended version of the story, Theophilus is vilified to a greater extent than he is in Ps.-Martyrius's account. Palladius describes him as an irascible character who flies into a tirade at a moment's notice and attempts to undermine anyone who stands in the way of his violent ambitions. He also presents the backstory to John's troubles with Theophilus, which includes a detailed description of his harboring of the Nitrian monks within the walls of city

Ommeslaeghe offers a necessary corrective to an overemphasis on the Origenist controversy as the chief cause of John's exile using source material from the Ps.-Martyrius. This work stems out of van Ommeslaeghe, "De lijkrede."

55. Translation altered slightly. The phrase "make ourselves exiles" is phygades tēs chōras katestēmen. 
of Constantinople. ${ }^{56}$ Their arrival in the city is due in no small part to Theophilus's inability to conduct his ecclesial duties in a just manner. Palladius goes on to shame Theophilus's treatment of the monks in his description of one particularly violent scene:

Certain monks went down to Alexandria with their priests to ask Theophilus to state the reason why they were condemned to be cast out. He regarded them like a dragon with bloodshot eyes. He glared like a bull. With his temper beyond control, he was at first livid, then sallow, and then smiling sarcastically. He snatched the pallium from the aged Ammonius and twisting it around his neck he inflicted blows upon his jaw, making his nose bleed with his clenched fists, and kept crying out: "Anathematize Origen, you heretics!" (Dia. 6)

Heretic or not, Palladius asserts, "one does not treat evil with evil, but evil with good," as a corrective (Dia. 6). The monks subsequently flee Alexandria and eventually make their way to Constantinople for refuge. ${ }^{57}$ Subsequently, John appeals to Theophilus pastorally as a fellow leader of the flock to correct, lovingly and fairly, the wayward.

Theophilus's arrival in Constantinople and his foul treatment of John only further supports Palladius's description of a leader who has lost control. In order to compensate for his failure in his own episcopal see, the madman attempts to cover up his own inadequacies by invading Constantinople. The invading bishop then participates in all manner of sins. He is violent, vengeful, and worst of all, "Theophilus not only spoke as a god, but even imagined he was god” (Palladius, Dia. 7).

John, ever the hospitable leader, welcomes both the wayward monks and Theophilus. If John possesses any fault in this unfortunate tale, it is his generosity for all. His intervention in the controversy ensures his fate as a victim of this insatiable villain's ire. The rest of the section traces Theophilus's endless pursuit to see John come to an untimely end. After he successfully brings about John's first, albeit brief, exile, Theophilus flees back to Alexandria.

After narrating Theophilus's flight, Palladius must momentarily tend to a more pressing issue: John's aiding and abetting of the fleeing monks. In the second section of his narrative, he is forced to contend with the issue of the Nitrian monks in more detail, along with John's controversial relationship with the deaconess Olympias. This section points to the larger controversy circulating in the background of this text. It is not the Arians that trouble Palladius, but those who are invested in the Origenist controversy. John has thus been tied into this later controversy as well, even though it does not take center stage until after his death. Nevertheless,

56. Palladius found himself embroiled in the Origenist controversy due to his friendship and frequent association with some of the biggest fourth-century supporters of Origen (ca. 184-254).

57. Isidore and the Tall Brothers were evicted from the Nitrian desert in 40o. The exiled monks first headed to Palestine but then continued on to Constantinople and arrived by 401 . See Jerome, Ep. 90 (Edition: CSEL 55); and Palladius, Dia. 17. 
as it was for Origen, even death does not place sufficient distance between oneself and the charge of heresy.

Olympias's decision to house and care for the exiled Origenist monks, for example, takes up a great deal of attention. In the first section, Theophilus was already branded as the antagonist and his authority undermined. The deacon listening to the defense, however, is not convinced of John's innocence in relation to the wayward monks. The stench of heresy is too strong to place all the blame on Theophilus, at least until the smell has dissipated. Palladius's inquisitive deacon remarks, "We grant that Theophilus performed a rash action in exiling them [the Tall Brothers], whether they really were orthodox or heretical. At any rate, the deaconess should not have taken them in" (Dia. 16). It is undoubtedly troubling, we are to assume, that a deaconess housed monks who were exiled by a bishop, even if that bishop's authority is questionable at best. Her involvement in the scandal must therefore be dealt with, especially since Olympias is the known benefactress of John. In addition to John, Olympias (and all of John's supporters) must also be cleared of all charges of heresy. Palladius justifies her actions by stating that the sympathy she showed the monks is a testament to her Christlike commitment to charity. He reminds his readers that Jesus fed a mixture of good and evil persons among the three thousand and that he ate and drank with both publicans and sinners. Olympias, like John, is guilty of nothing more than extreme, albeit naive, generosity. Once Palladius has cleared the air, he turns once again to the cityscape in order to restore John's name and reputation.

The final section of Palladius's Dialogue darkens as the entire eastern empire quickly deteriorates into a landscape of lawlessness. Stories of suffering overrun this section of the work and leave the reader with a sense of desperation and hopelessness. To solidify his argument, Palladius begins by taking stock of all those bishops who were sent into exile along with John: "I am referring to Eulysius and Palladius and Cyriacus and Demetrius. We have heard by the grapevine that they were banished" (Dia. 19). Their fate, much like John's, is to suffer for their orthodoxy. Their suffering is the very proof of their innocence, but the picture grows dim as the battle between good and evil wages on and they are thrown into further chaos: "As for the bishops, a first rumor had it that they had been drowned in the sea. However, the true story is that they were banished beyond the borders of their own territory into barbarian zones, where they are even now still kept prisoners and under police guard" (Dia. 20). Palladius then provides a lengthy list of the whereabouts of and the inflictions suffered by each of the exiled bishops scattered across the empire. For example, "Serapian ... underwent bodily tortures at the savage treatment from his judges, even to the extraction of his teeth. ... Hilarius, an aged holy man, was transported to innermost Pontus after he was beaten up, not by the judge mind you, but by the clergy. . . . Heracleides of Ephesus has been shut up in the prison of Nicomedia for four years now" 
(Dia. 20, emphasis mine). ${ }^{58}$ As Palladius highlights here, the enemies of the faithful are not the enemies of old, although they too take pleasure in inflicting harm. These enemies are the false clergy, who are to blame for the most horrendous acts of violence. Palladius points to the treatment of the blessed Eutropius to stress his point: "undefiled of women, a cantor, was struck and flayed most unmercifully on his sides and forehead so that his eyebrows were pulled out. Finally oil lamps were lit close to his ribs, which had been laid bare to the bone on both sides, and he expired on the rack. He was buried in the middle of the night by the clergy who had committed this crime" (Dia. 20, emphasis mine). Palladius uses what should now be a familiar theme: exilic discourses continuously invoke a past of persecution in order to substantiate authentic orthodox Christian identity. The imperial thugs are no longer the instigators of imperial persecution; it is now the false clergy who eagerly partake in these nefarious activities. This past, Palladius stresses, does not disappear with the arrival of so-called Christian emperors or with the surfeit of professed Christians in the church. Instead, we are to conclude that the mixing between empire and heretics is the ultimate cause of this particular dystopian nightmare. The picture is indeed bleak. Palladius then provides proof text after proof text that the end times, which were inaugurated with John's exile, have arrived. ${ }^{59}$

John's orthodox flight is the ultimate testament of truth. His banishment and subsequent suffering give hope to others who suffer the same fate and provide yet more people with an excellent example of someone who had no earthly claims. His suffering was his bodily condition in this world. Even before John was exiled, Palladius states, he held this life at a distance. His focus was on performing good works, not amassing wealth or human prestige. His suffering would therefore be beneficial to all who continue to read about his life: "He did not make a will in regard to his property, since he had already disposed of all by his life and thinking. Did death knock at the door of his emaciated body? Before John beheld him outside, he shouted: 'Let us go from here', and he intoned the Psalm: 'Woe is me that my sojourn has been so long'" (Dia. 20). Palladius then contrasts this exemplary man with those who claim to be orthodox but are instead false Christians, who also flee, but flee as cowards. He then turns back to Theophilus:

His nights are sleepless and troubled. He imagines plots against himself even by his associates. He has lost faith in himself and distrusts all men as liars. This is what he resembles: he is as cowardly as a rabbit, as bold as a swine, as deceitful as a chameleon, as roguish as a partridge, as pitiless as a wolf, and as untamable as a mouse. He is his own enemy, jealous without cease, punishing himself though he reckons it not. One who continually plots evil for others inevitably brings it on himself. (Dia. 20)

58. The phrase "not by the judge ... but by the clergy" is ou dikastou, alla tou klèrou. 59. 1 John 2:19; 2 Thess 2:3; John 2:18; Matt 20:1, 6. 
While Theophilus harbors safely in Alexandria, the faithful continue to live with this ongoing nightmare and are forced to flee in every direction. Nevertheless, Theophilus points to an eventual resolution. Palladius closes his dialogue by reasserting that John's exile will not go unrectified, even though, at present, it causes insurmountable suffering. The faithful now live within a nightmare, but justice will come: "For even though the blessed John has gone to sleep, nevertheless, truth is very much awake, for which a search will be made" (Dia. 20). The final judgment has yet to come, Palladius insists: "The divine justice will hunt them down to correct their evil actions" (Dia. 20). Peace will be restored and the church of Constantinople will once again be a heavenly city.

John's vision of a utopian Constantinople comes under threat with the invasion of a competing urban space. In his Epistle 7, Constantinople's position as a preserved city of orthodoxy quickly crumbles, as John's troubles escalate and he is exiled. His quick tongue, hot temper, and reforming practices, according to both his ancient and his contemporary biographers, make it easy to see why such a divisive figure found himself deposed from his position. John's own interpretation of the events that eventually lead to his exile, edited and reframed by Palladius, creates a powerful exilic discourse about the rivalry at play between Alexandria and Constantinople. This urban defender of Nicene orthodoxy comes to blows first in John's exilic discourse. And once Palladius enters into the Origenist controversy, the spatial imagination defines the terms of his orthodox project through a dystopian vision of crumbling landscapes and displaced men.

HOW TO RETURN FROM EXILE: ATHANASIUS

AND JOHN CHRYSOSTOM

We have seen that the difficulty in writing the history of John's exile is generated by the consistent conflation of various representations of his exile. By focusing instead on the use of space and place in each text independently, we now discover new ways to examine John's exile. I have drawn to the fore how the different investments of each author shape each text. As we saw in John's apologetic treatises, in the last chapter, he characterizes his exile as a universal condition. The exilic condition is not defined by any earthly homeland but by a heavenly politeia. Here we see a similarity to Athanasius's exilic discourse, which transforms into an embodied orthodoxy that is bound neither by space nor, in Antony's case, by time. But this universalized exilic discourse is not what survives. As Palladius and Ps.-Martyrius demonstrate, the orthodox process is dependent upon John's exilic discourse localized in the city and an eventual return. These biographies show us most clearly how displacement secures John's identity as an exile. But is this enough to ensure his orthodoxy? Ultimately, John's memory is successfully resurrected, but only with the help of a victorious Alexandrian legacy-not that of Theophilus, but of Athanasius. 
We might now understand why the intersection of exilic discourse with the discourse of orthodoxy and heresy is so productive in the afterlives of these exiled bishops. The exiled person, while fragile in his displacement during his own time and exile, embodies an orthodoxy that can be used and (re)placed by his biographers. The exiled bishop lives on as a moveable object. His narrative is constructed through literary tropes in order to promote and sustain definitive borders of what is considered and will eventually constitute a pro-Nicene orthodoxy that is unquestioned. We will explore this argument in the next chapter. For now, let us turn back to Athanasius and his refashioning of his second exile to see how John's biographers connect their hero to this emblem of orthodoxy.

In the summer of 339, Athanasius composed his Encyclical Letter while safely harbored in Rome, in which he constructs an identity as both victim and victor. ${ }^{60}$ The contents of the letter describe for his audience the series of dramatic events that resulted in what is considered his second exile. ${ }^{61}$ It is in this encyclical that Athanasius first constructs himself as a persecuted victim, while simultaneously stylizing himself as an unconventional literary hero. He accomplishes this through several steps. In his effort to create an unstoppable protagonist, Athanasius creates the most threatening of enemies: Gregory of Cappadocia. He then describes a particularly violent scene that had devastating effects on the faithful. Finally, he argues that his eventual flight was necessary for the benefit of the Alexandrian community and the church at large.

Athanasius begins his letter by emphasizing that Gregory is no ordinary villain. He is a foreigner with a particular taste for blood and a penchant for keeping bad company. Gregory and his associates are all "Arian madmen" (Ep. encycl. 2). ${ }^{62}$ To drive home the dubious nature of these intruders, he makes it clear that these men were, in fact, those responsible for his first departure to Trier. He then turns to a climactic moment that condemns his enemy further. Gregory's bloodlust is not for Athanasius alone but extends to the entire city of Alexandria. In the days preceding Athanasius's flight to Rome, Gregory gathered his Arian madmen and other co-conspirators, such as a known Manichean general, along with his disreputable imperial soldiers, to storm the "Great Alexandrian Church" (Ep. encycl. 7). ${ }^{63}$ Calamity ensues, and Athanasius describes the disaster as follows:

The church and the holy baptistery were set on fire, and straightway groans, shrieks, and lamentations were heard through the city; while the citizens, in their indignation

6o. Athanasius, Ep. encycl. Edition: Opitz, Athanasius Werke 2, 169-77.

61. Barnes, Athanasius and Constantius, 50.

62. For a detailed discussion on the rhetorical degradation and creation of the category of Arian madmen in Athanasius's other works, see Burrus, Begotten, Not Made, 47-68.

63. According to Barnes, the "Great Alexandrian Church" to which Athanasius refers here is the Church of Dionysius mentioned also by Socrates, Eccl. Hist. 2.11, 6, and Julius, Ep. 1 (341); see Barnes, Athanasius and Constantius, 49. 
at these enormities, cried shame upon the governor and protested the violence used against them. For holy and undefiled virgins were being stripped naked, and suffering treatment that is not to be named, and if they resisted, they were in danger of their lives. (Ep. encycl. 3)

Here I want to point out two details: First, the chosen location of this attack is the very heart of the Christian church: the baptistery. Second, virgins, presumably sexually assaulted in this scene, are highlighted as the chief victims of this attack. Gregory's violence is highlighted as both excessive and intentional. He targets the most vulnerable within the community. What is also striking about this passage, aside from the horrific events described, is the way this storyline develops over the course of Athanasius's career as an exile. This event is detailed along with the atrocities enacted by Gregory's successor, George, in both his Defense before Constantius and In Defense of His Flight. ${ }^{64}$ These attacks upon Athanasius and the vulnerable continue to take place as if the imperial persecutions were still alive and well. ${ }^{65}$ The only difference in this new martyrdom is that the bishop flees in order to stay alive.

Athanasius's survival does not go without criticism, however, and he must answer to the charge of cowardice in his Defense of His Flight. In this text, Athanasius concludes that it is more cowardly to persecute the innocent (i.e., the virgins and the elderly), while it is manly and Christlike to flee (Fug. 2.1). In short, this bishop is more valuable alive than dead.

Athanasius outlived his enemies and eventually returned to Alexandria triumphant. As we saw in chapter 2, his story takes on mythic proportions as it travels across the empire. Gregory of Nazianzus, in his panegyric delivered in Constantinople on the anniversary of Athanasius's death, never questions Athanasius's decision to flee. And to legitimize his hero's flight, Gregory goes so far as to describe Athanasius's exiles as an "illustrious banishment" and not an exile (Orat. 21.27). This point is proven by his successful return to Alexandria, which is the focal point of his speech. As Gregory narrates it, Athanasius enters the city with accolades and cries of victory over the Arian enemy.

Athanasius's legacy as a persecuted victim is thus intimately tied to graphic stories of violence and suffering, such as the invasion of the Alexandrian church and baptistery. Athanasius's survival is nothing short of miraculous and certainly lives on as a story of legends. ${ }^{66}$ With each retelling, this story of triumph became

64. Athanasius, Apol. Const. 27, and Fug. 6.24. The texts are discussed in chapter 1.

65. Julia Hillner, Prison, Punishment, and Penance in Late Antiquity (Cambridge: Cambridge University Press, 2015), 249-55.

66. Athanasius's repeated escape does not go without criticism. In the Defense of His Flight, Athanasius must address the charge of cowardice. Ultimately, he'll conclude that the death of martyrs, while valuable, is not the only example set by Christ. The command to flee during times of persecution in 
intertwined with the victory of Nicene orthodoxy and, therefore, the victory of the saint. Athanasius's story continued to take on cultural capital across the empire as Nicene Christianity built momentum, particularly in Constantinople. As the so-called defender of the faith, the Alexandrian bishop's reputation was used to substantiate other claims to orthodoxy and to rehabilitate, even posthumously, those like John Chrysostom who suffered from the suspicion of heresy. Unlike Athanasius, however, John did not have a victorious return, at least not while he was alive.

Both Ps.-Martyrius and Palladius successfully transform this questionable exile into a saint through the aid and agency of Athanasius. They accomplish this task by drawing strong narrative connections to the Nicene hero's struggles with invading bishops. The violence inflicted upon John's supporters and subsequent damage to the Constantinopolitan church also mirrors those events described in Athanasius's Encyclical Letter. Finally, John's biographers explicitly refer to Athanasius as a way to legitimize John's orthodoxy and transfer the Alexandrian legacy to Constantinople.

The literary connections begin when we compare invading episcopal competitors. Theophilus, for example, was a conniving politician whose lust for power extended well beyond the borders of his episcopal see. He leaves Alexandria and travels to Constantinople in order to convoke the Synod of the Oak and condemn John. Although John was never present at the synod, his absence ensured a guilty verdict. As Elm has noted, no clear doctrinal issues appear to be at stake between the two men, or at least no overt charge of heresy was made at the synod. John was never labeled an Origenist, for example. One does not have to be called an Arian or an Origenist, however, to be implicated by the company one keeps. Heresy by way of association is enough to discredit one's opponent, as we have seen time and again.

Guilt by association goes both ways. John's two biographers are fully aware of such rhetorical strategies and thus make use Athanasius's story to clear John of any wrongdoing, heretical or otherwise. Both Johanite apologists go further to turn the charge on its head and accuse Theophilus, not John, of keeping bad company. In both texts, Theophilus stands as John's literary foil and functions in a similar way to Athanasius's chief rivals. Theophilus's role as an invading bishop who colludes with other known heretics, criminals, and imperial officials bent on persecuting the orthodox was not lost on John's supporters. This is a story we have heard before. The actions of this invading bishop actively undermine his claim to the power of the Alexandrian episcopate or, at the very least, his orthodox legacy. That authority shifts to a new context and a new bishop. As we will come to see,

Matthew 10:23 is frequently cited by Athanasius and other fleeing bishops ("If they persecute you in this city, flee into another") (Athanasius, Ep. encycl. 5). 
Constantinople and John Chrysostom are the true inheritors of the Athanasian legacy. The city envelops Alexandria as Athanasius's story is first carried in and then reread within its walls.

The narrative sequence of violence explored in Athanasius's encyclical is inserted into both Ps.-Martyrius's and Palladius's accounts. In the Funerary Speech we see:

When some of those who come to the holy rites of initiation had just emerged from the pool of the baptismal font, others were still in it, and others were ready to immerse themselves, [when] a solid mass of soldiers entered with swords and clubs.... They beat and drove out those who lacked both clothing and sin, ... sparing no one, not even women, whose natures have taught especially to feel shame at being naked [Gen 3:7-11]. (Ps.-Martyrius, Fun. Orat. 93)

Once again, it is the baptistery that is invaded and, in their mad pursuit of John, these enemies target the faithful, even persons in the very process of Christian initiation.

We see an extended version of this same event in Palladius's text. Like Ps.-Martyrius, the attack on the church takes place at the Easter Vigil. A vicious soldier named Lucius the Greek brings with him known clerics of John's rival and enlists swordsmen to storm the inner sanctuary of the church. ${ }^{67}$

At night, he suddenly rushed to attack, furious, like a wolf, along with the priest who showed him and his soldiers the way. He pushed through the crowd with a sword, he came forward to the holy waters and cast out those who were about to be initiated into the Resurrection of the Savior. He arrogantly pushed aside the deacon and spilled the symbols of the mysteries. As for the priests, who were of a certain age, he struck their skulls with a club and defiled the baptismal pool with their blood. ... Naked women with their husbands were running away wounded, disgracing themselves for fear of being killed or disgraced. (Dia. 9.196-205)

In both narratives, John's enemies invade the baptistery, treat the initiates violently, and lay out the naked bodies of women before us. It is as if Gregory's attack has taken place once again, only this time in Constantinople. The faithful are tortured and, as we might expect, the bishop is expelled.

If the familiar narrative structure were not enough to link Athanasius to John, both authors explicitly refer to "the Great Athanasius of Alexandria" when they discuss the aftermath of John's first exile and presumably illegal return to Constantinople. Each author reports that, after the legitimacy of the Synod of the Oak was called into question, Theophilus fled back to Egypt and John was recalled from exile. The emperor Arcadius demanded an explanation, and Theophilus was also requested to return. He refused to do so and sent representatives instead. Theophilus's delegates did not come empty handed but carried with them the same canons that were meant to discredit and condemn Athanasius. In Ps.-Martyrius's account,

67. This character parallels Philagrius, the prefect of Egypt and noted kinsman of Gregory in Athanasius's story; see Athanasius, Apol. sec. 5.4, and H. Ar. 10.1. 
we read: "Having thoroughly investigated every form of slander and wickedness and having discovered that all <their efforts $>$ were being overcome by the truth, they sought refuge in the illegal laws of the Arians and with them plotted evil concerning the saint [John], copying < the Arians'> madness concerning the blessed Athanasius" (Ps.-Martyrius, Fun. Orat. 98). Athanasius's supposed illegal return to his episcopate is invoked to parallel that of John's experience. Ps.-Martyrius describes the contents of the letters as follows:

But being worsted in everything by the man's [Athanasius's] freedom of speech and by the true course of events, they finally deposed him on the grounds that he was a father of heresy and falsified the teaching of the apostles. However, suspecting a change in the political situation, they added to the deposition <of Athanasius $>$ a law that laid down that it was in no way whatever permissible for a deposed person to have his case adjudicated a second time. (Fun. Orat. 99)

Ps.-Martyrius seeks once again to overlay John's story with that of Athanasius. Like Athanasius, John's fatal flaw appears to have been his daring decision to return. Despite the accusations of heresy and general misconduct, these two bishops defied the stipulations of their depositions. According to Ps.-Martyrius, Athanasius's enemies, knowing that the charge of heresy would not stand (just as John's would not), added an additional clause stating that a second trial could not take place after a bishop had been deposed. John, even after an unnamed countercouncil cleared him of all charges of heresy, violated this added precautionary measure.

Palladius also refers to these same documents. The story repeats: After John returns from his first exile, Theophilus sends delegates with "certain canons, which the Arians had composed against the blessed Athanasius" (Dia. 9.19-20). These laws are ultimately deemed false by Palladius, given their dubious origins, but nevertheless cause him pause. He must explain why John does not violate any canons, legal or illegal. First he states, “They [John's enemies] thought that by the use of these canons they could devise a judgment against John, because he had returned to his see after being deposed-and that was on his own initiative" (Dia. 9.19-20). ${ }^{68}$ Palladius later details the contents of the canons in question: "The forty bishops who held communion with Arius had legislated that if any bishop or any priest who had been deposed, justly or unjustly, should reenter his church on his own initiative, without permission of a synod, such a one shall have no opportunity of defense, but shall be absolutely excluded.' Now that

68. Barnes and Bevan note that the canons appear to be from an Antiochene council c. 327; see Barnes and Bevan, Funerary Speech, 216n95. The reaffirmation of these canons is then linked to the Council of Antioch in 341; see Palladius, Dia. 9.60-63. The canon reads, "if a bishop deposed by a council ... attempts to perform any liturgy, ... it should no longer be possible for him to have a hope of being restored or the opportunity of defending himself, not even at another council." Edition: Joannou, CSP, 1962b, 107. 
canon was found to be lawless and passed by lawless persons" (Dia. 9.62-65). Palladius goes on to explain that these canons, presented to the emperor Arcadius, caused a great deal of confusion. Some agreed they were illegal, while others deemed them orthodox.

Palladius notably makes no mention of a countercouncil that cleared John of his charges. Instead, he dismisses the Synod of the Oak as an illegal civil tribunal and states that John's first removal was not, in fact, a legal deposition. John's initial return, then, did not violate any canon law, no matter its origins. This statement, of course, undermines Ps.-Martyrius's narrative, which may have more to do with Palladius's own precarious position as an exile and attempt to return than with John's activity.

Ps.-Martyrius and Palladius do agree, however, that the attempts to use these canons by John's enemies forge a strong link between John and Athanasius. It is John, not Theophilus, who is the rightful heir of Athanasius's legacy. The narrative of John's persecution and expulsion mirrors that of Athanasius's account discussed in the encyclical. Moreover, the canons carried by Theophilus's delegates reflect the charges of heresy and misconduct back upon John's accusers. It is the company Theophilus keeps, not John's associates, that condemn this invading bishop.

\section{CONCLUSION}

The Athanasian legacy was so successful that, by the time John Chrysostom's seemingly failed exile took place, the simple act of invoking Athanasius's experience was enough to resurrect and rehabilitate John's memory. Athanasius's larger-than-life persona as an exile was carefully constructed both in his own writings and in those of his supporters. His many exiles served as a powerful narrative and identity that was recycled across the empire. While stories of Christian orthodoxy were still intimately tied to the not-too-distant past of imperial persecution, claims to Christian authority were derived not from the dead but from the living. Unlike the heroic martyrs before him, however, Athanasius was not simply a victim. His legitimacy was confirmed by his ability both to suffer and to defend. He survived so others might live. John Chrysostom, like Athanasius of Alexandria, was brought back to the city and triumphantly proclaimed a defender of the faith precisely because his exile mirrored that of his literary and orthodox predecessor.

We began to see in this chapter how the Athanasian legacy and its role in preserving or challenging orthodox identities functioned in and around Constantinople. That legacy frames our understanding of John Chrysostom's political and theological troubles as the reigning bishop of that contested city. As we saw in chapter 3, certain alliances with Antioch continued to cause trouble for those men who attempted to hold on to the episcopal office in Constantinople. It is not 
surprising that John's support of Meletius of Antioch and his connections with his successor, Flavian, did not endear him to the Alexandrian patriarchate and, by extension, the pro-Athanasian legacy. Yet, in hindsight, John Chrysostom has still been remembered as an unquestionably orthodox figure. And we now begin to see how John's biographers played a key role in reviving not just John's reputation but Athanasius's as well. The Alexandrian legacy as a pro-Nicene position must be moved to Constantinople and embodied in stories of its heroes. At least, this is the claim the ecclesiastical historians would make, to which we will turn in the final chapters. As they, too, sift through and (re)place the bodies of bishops in flight, they will reset the stage of the pro-Nicene narrative and reinforce one of the primary arguments of this book: the space and place of orthodoxy is central to our understanding Christian flight in late antiquity. 


\section{5 \\ To Condemn a Bishop in Flight}

But they [Athanasius's accusers] were so overwhelmed by the consciousness of their own evil deeds that they took to flight and, by this flight, clearly proved the falsity of their accusation, as well as their own guilt.

-THEODORET, ECCLESIASTICAL HISTORY ${ }^{1}$

Not all Christian flights were created equal. With the aid of pro-Nicene authors, Athanasius of Alexandria's multiple flights quickly became the standard for an orthodox exile. But the charge of cowardice-or worse, heresy-was not so easily dismissed. While Athanasius attempted to explain away such charges, as did many of his defenders, not all could escape such a damning verdict. In this and the following chapter, we will explore how the enemies of Nicaea, reread as the enemies of Athanasius, also found themselves in exile. But their episcopal flights were no testament to their virtue. As the quote from Theodoret's Ecclesiastical History above demonstrates, the exiles of anti-Nicene bishops were remembered within pro-Nicene Christian tradition as evidence of their guilt.

The post-Nicene age may have begun with Athanasius's death, but the legends of Nicaea began with the literary birth of his enemy, the Arians. ${ }^{2}$ This birth was intimately tied to his life in flight, as I demonstrated in chapters 1 and 2. And we explored in chapter 4 how Athanasius's Encyclical Letter inaugurated his exilic discourse as both the victim of-and victor over-heresy. As should be evident by now, it is impossible to have heroes without villains. The pro-Nicene contingent created larger-than-life enemies to reinforce their status as victims, whether they be emperors or heretics. Despite the best efforts of later pro-Nicene authors,

1. Theodoret, Eccl. Hist. 2.6. Greek: L. Parmentier, F. Scheidweiler, and G. C. Hansen, Theodoretus Cyri, Kirchengeschichte, 3rd ed., GCS, vol. 19 (Berlin 1998). Translations of text are in consult with the Greek and NPNF2 3, unless otherwise noted.

2. For the beginning of the post-Nicene age, see Richard Lim, Public Disputation, Power, and Social Order in Late Antiquity (Berkeley: University of California Press, 1995), 183. For the beginning of the legends of Nicaea with the creation of the Arians, see Burrus, Begotten, Not Made, 48-58. 
those villainous anti-Nicene bishops were not always representative of a minority point of view. In fact, from 325 to 337 , it appeared as if Nicaea's ideals would be overthrown. A series of councils in the Eastern Roman Empire appeared to have replaced its more controversial claims, such as the now (in)famous term homoousios. Many cities within Asia Minor were decidedly anti-Nicene and had begun to rally around particular figures to combat what they perceived to be heretical ideas espoused by Alexander of Alexandria and his successor, Athanasius. Two cities, in particular, stand out both in the heat of the moment and well after the conflict over Nicaea had come and gone, namely, Nicomedia and Antioch. ${ }^{3}$ In these final two chapters, we will turn to these two powerful urban centers to once again assess how episcopal flight from particular spaces was intimately tied to the process of crafting orthodoxy.

Here we will critically examine the various competing narratives related to the exile and legacy of Athanasius's chief enemy, Eusebius of Nicomedia. Even though Eusebius died the bishop of Constantinople, his memory was tied to an alternate, and theologically rich, space. We will begin by assessing how the city of Nicomedia became a significant focus within the memory-making exercise of the fourth- and fifth-century ecclesiastical historians. Next, we will turn to Nicomedia's role in how its bishop, Eusebius, would be remembered. We then will attempt to reconcile why the bishop of Nicomedia's episcopal career might pose a spatial threat to proNicene historians. Finally, we will conclude that Eusebius's flight from and return to the city of Nicomedia was woven into a recognizable and effective story of failure. And so, now, we once again turn to the city in order to better understand the man who fled from it.

\section{HOW TO CONDEMN A MODEL CITY: NICOMEDIA}

The city of Nicomedia, founded in 264 BCE, was given its name by Nicomedes I. It was the capital of Bithynia Prima, while its neighbor, the city of Nicaea, was frequently referred to as the capital of Bithynia Secunda. ${ }^{4}$ The fourth-century writer Lactantius, among others, note that Nicomedia was the favored imperial residence of that nefarious emperor Diocletian, who made it the eastern Roman capital in 286 CE. ${ }^{5}$ It was also in Nicomedia that the young Constantine was tutored and where he prepared for his position as the future Caesar-a position

3. Ayres reconstructs the series of councils, key bishops, and cities that made a significant effort to undermine the creeds established at Nicaea; see Ayres, Nicaea and Its Legacy, 101-3.

4. For a recent entry on Nicomedia and Nicaea, see Klaus Belke, Bithynien und Hellespont (TIB 13), in press / forthcoming, s.v. Nikomedeia / Nikaia. Belke breaks down the archeological evidence as well as literary references to these significant cities.

5. For a biographical reconstruction of Lactantius's time in Nicomedia and when and where he wrote his Divine Institutes and On the Death of Persecutors, see T. D. Barnes, Constantine and Eusebius (Cambridge, MA: Harvard University Press, 1981), $291 n 96$. 
he was ultimately denied, in favor of Galerius. The most damning detail, however, remains that Nicomedia was where the edict of the Great Persecution in 303 was issued and where Lactantius reportedly witnessed firsthand attacks on the Christian community. ${ }^{6}$ It was in Nicomedia that Eusebius of Caesarea, another foundational ecclesiastical historian, states that the co-emperor Licinius would ultimately lose his life for his continued use of violence against Nicomedian Christians even after Constantine's edict of toleration was put into effect. It is unsurprising that later pro-Nicene historians place a great deal of emphasis on this fact. Nicomedia's reigning significance as a site of Christian persecution and the seedbed of the most horrific enemies of the church was not lost on later pro-Nicene writers.

And still, Nicomedia's significance as a powerful city in Christian memory continued to pose a set of historical challenges for those invested in condemning its memory. As our two earliest historians argue, Nicomedia remained an ambivalent space for Christians. Both Lactantius and Eusebius of Caesarea spent a great deal of their career either in or writing about Nicomedia, and they provide us with a rare glimpse into the historical exercise of remembering a contested city. Again, it is from Lactantius that we hear firsthand how Diocletian's persecution was sparked within the city's walls. And it is his detailed reports concerning the burning of books, the destruction of churches, and the first executions that are later recycled in many of the texts we have already explored.7 It is also from Eusebius of Caesarea that we learn about the persistence of persecutions even after Constantine's successful military campaign. Despite these details, not all visions of Nicomedia were negative.

These fourth-century authors also understood how space could be imbued with cultural and religious significance under the right circumstances. Jeremy Schott has argued, following the lead of Bruno Breckman and T. D. Barnes, that Nicomedia was the site where Constantine delivered his Speech to the Assembly of

6. "While it was still twilight the prefect came to the church with military leaders, tribunes, and accountants. They forced open the doors and searched for the image of God. They found the scriptures and burnt them; all were granted booty; the scene was one of plunder, panic, and confusion.... Bringing axes and other iron tools, and after being ordered from every direction, they leveled the lofty edifice to the ground within a few hours" (Lactantius, Mort. 12.2-5). Edition: SC 39 and Creed, Lactantius, De Mortibus Persecutorum. Translation: David M. Gwynn, Christianity in the Later Roman Empire: A Sourcebook (London: Bloomsbury, 2015), 20 (with some slight alterations).

7. When we place this narrative alongside the details in Athanasius's Encyclical Letter, we are presented with a counter-narrative. The burning of church buildings as evidence of Christian persecution stands out. And, as Shepardson has argued in her examination of the contested readings of the ruins of the burned Temple of Apollo, the destruction of the built landscape played an important role in identifying orthodox spaces during this period; see Shepardson, Controlling Contested Places, 67-79. As we have already seen, Athanasius takes great pains to note that the persecution in Alexandria began with attacks on two important churches in the city. A similar case was made earlier by Lactantius, who remarked that the destruction of the Nicomedian church was seen as a direct assault on Christianity. See chapter 4. 
Saints. ${ }^{8}$ In this speech, preserved in in Eusebius's Life of Constantine, we learn that Constantine describes Licinius as its unworthy champion and then condemns its heritage of persecution. ${ }^{9}$

The great city acknowledges this and praises with acclamation; and also the people of the dearest city wish <to do the same $>$, even if formerly, deceived by false hopes, it chose a champion unworthy of itself, who was at once caught in a manner appropriate to and worthy of his rash deeds, which it is not right to record, especially for me, as I speak to you and take all care to address you with holy and auspicious utterances. ${ }^{10}$

In the storyline of that great savior, the emperor Constantine, only one champion can redeem the city's sordid past. Licinius, unable to occupy the savior's position, seized hold of this territory and could not resist the temptation to persecute its Christian inhabitants. Constantine, by way of contrast, was the only true victor, the one who could break this curse.

At the end of Eusebius of Caesarea's panegyric, we learn that even this great man could not resist the allure of the city. ${ }^{11}$ While the emperor chose to build a new city in the port city of Byzantium, he nevertheless decided to reside and then die in Nicomedia, not Constantinople. Eusebius goes on to report that Constantine's crowning moment was his decision to be baptized on his deathbed and to encourage others to follow his lead. ${ }^{12}$

And yet this last imperial act was not enough to wash away the stain of persecution that persisted in Nicomedia and threatened to mar the emperor's reputation. Constantine's baptism took place in Nicomedia remained an embarrassing detail that later writers sought to explain away. Even Eusebius of Caesarea made frequent attempts to say that the company the emperor kept at the end of his life was not

8. Jeremy Schott also takes note of this memory-making process; see Schott, Christianity, Empire, and the Making of Religion in Late Antiquity (Philadelphia: University of Pennsylvania Press, 2008), 111-13. Schott highlights the significance of Nicomedia as the presumed site of Porphyry's anti-Christian polemics during and after the Christian persecution or where Lactantius wrote his Divine Institutes as an eyewitness to the destruction of the Christian churches $(53,81-82)$.

9. Constantine, Speech, 25.4. This speech is preserved in Eusebius of Caesarea, Vit. Const. Efforts to preserve the text as separate from Eusebius's panegyric have resulted in the critical edition by I. A. Heikel, Eusebius Werke, 7 vols., Die Griechischen Christlichen Schriftsteller 7 (Leipzig: Hinrichs, 1902), 1:151-92. Translation: Barnes, Constantine and Eusebius, 30.

10. Constantine, Speech, 22.1.

11. For a description of the end of Constantine's life and his baptism, see Eusebius of Caesarea, Life of Constantine 4.61-64. Editions: CPG 3495; SC 31, 41, 55. Translation: Averil Cameron and Stuart George Hall, Eusebius: Life of Constantine, Clarendon Ancient History Series (Oxford: Clarendon, 1999).

12. As Gwynn notes, Constantine's baptism by Eusebius of Nicomedia is only overtly credited by Jerome in Chronicon 2353. The pro-Nicene authors go to great lengths to avoid directly associating the baptism with the Nicomedian bishop. See Gwynn, Eusebians, 18n44. See also Garth Fowden's discussion of the various traditions associated with Constantine's baptism in "The Last Days of Constantine: Oppositional Versions and Their Influence," Journal of Roman Studies 84 (1994): 153-70. 
without the occasional false Christian-alluding to the number of false Christians in Nicomedia. Nicomedia and its questionable legacy must be overcome. Yet Nicomedia-and, we will soon see, its bishop-must be dealt with precisely because Constantine was baptized and died there. The memory of both Constantine and that doomed city was eventually transformed, and like Athanasius's, Constantine (along with his memory) was safely transferred to Constantinople, not only to preserve the orthodoxy of the emperor but also to ensure the damning of his more problematic companion, Eusebius of Nicomedia.

\section{AN UNORTHODOX RETURN FROM FLIGHT: EUSEBIUS OF NICOMEDIA}

Eusebius of Nicomedia, the so-called leader of the Eusebians after the council of Nicaea, lived on in infamy primarily for his ongoing support of Arius and his staunch opposition to Athanasius. ${ }^{13}$ In the aftermath of the Nicene council, Alexander of Alexandria condemned Eusebius and his efforts to rehabilitate Arius. After Alexander's death, Athanasius followed closely in his mentor's stead and targeted Eusebius and his followers for his own polemical purposes. The evolution of animosity between the Alexandrian patriarchate and Eusebius is well documented. And it is unsurprising why this would be so. Eusebius appears to have been behind the appointments of both Gregory and George of Cappadocia and, according to Athanasius, was the mastermind behind many of the travesties committed in Alexandria. ${ }^{14}$

Although little is known about Eusebius's life other than his dealings with proNicene politics, many have assumed some familial ties to the imperial household. According to the ecclesiastical historian Philostorgius, whom we will explore in more detail below, Eusebius was a student under Lucian of Antioch, also known as Lucian the Martyr, and quickly rose through the ranks of both political and ecclesiastical importance..$^{15}$ Eusebius was, without a doubt, a well-connected man and a powerful broker of imperial politics. For instance, his familial connections were frequently commented upon by ecclesiastical historians. He appears to have had some relation with Julius Julianus, the praetorian prefect for the emperor Licinius (315-324) in the East-that is, the emperor who quickly lost his life when

13. For a helpful overview of Eusebius's contemporary biographical reconstruction, see Gwynn, Eusebians, 1133 .

14. See chapter 1.

15. Philostorgius, Eccl. Hist. 2.12. Edition: Joseph Bidez, Philostorgius, Kirchengeschichte. Mit dem Leben des Lucian von Antiochien und den Fragmenten eines arianischen Historiographen, ed. Joseph Bidez, rev. Friedhelm Winkelmann, GCS (Berlin: Akademie Verlag, 1981). Translation: Philip R. Amidon, Philostorgius: Church History (Atlanta, GA: Society of Biblical Literature, 2007), unless otherwise noted. It was Helena, Constantine's mother, who discovered the remains of the martyr Lucian washed up on the shores of Nicomedia. This detail is also preserved in Eusebius of Caesarea, Vit. Const. 52. The territory around the bay of Nicomedia is said to have been renamed Helenopolis after Constantine's mother. 
Constantine had had enough of shared rule. Surprisingly, even after Licinius's defeat, Eusebius appears to have retained his political influence and became an important member of the inner circle of Constantine. This appears to have been due to Licinius's wife, Constantia, who was Constantine's half-sister. The imperial interfamily politics, however brutal the outcome for many, continued to work in Eusebius's favor throughout his life and career.

A few other connections, more dubious in nature, are frequently commented on. Most notable was the rumor that Eusebius briefly tutored Julian-later emperor and Christian apostate. His association or influence over the young Julian might be another attempt to malign the bishop's reputation. ${ }^{16}$ Nevertheless, the relationship Eusebius had with imperial circles was an intimate one, though it was tense at times. Eusebius, like Athanasius, was exiled under Constantine. And while this exile is frequently noted by ecclesiastical historians such as Socrates (Eccl. Hist. 2.1) and Sozomen (Eccl. Hist. 2.28), many of the details are left out.

The reasons behind Eusebius's short exile and his return, like those of Athanasius's many flights, are difficult to reconstruct. ${ }^{17}$ It is unclear whether it was Constantine who initiated Eusebius's removal in September-October 325 (Socrates, Eccl. Hist. 1.9; Sozomen, Eccl. Hist. 1.21) or a particularly active pro-Nicene council of bishops (Philostorgius, Eccl. Hist. 1.10, 2.1). Eusebius, like Athanasius, appears to have been exiled to Gaul along with the lesser known Theognis (Socrates, Eccl. Hist. 2.8). And like the Alexandrian bishop, he is permitted to return. His return is equally as difficult to reconstruct. Socrates insists he is permitted to return in 328 after Constantia, Constantine's half-sister, is said to have appealed to the emperor on his behalf (Socrates, Eccl. Hist. 1.14). As we have explored elsewhere, a similar appeal was made on Athanasius's behalf by Constans, the youngest son of Constantine..$^{18}$ And so the historian is left to ask if Eusebius eventually restored to his episcopal see due to the reconnaissance efforts initiated by his friends at court? Or was he allowed to return because his version of orthodoxy was slowly becoming the favored interpretation among eastern bishops? These questions cannot be answered here. What we are able to glean from this particular departure and return is how Eusebius's exile plays into his legacy as a heretic, even when all evidence points to

16. See Ammianus Marcellinus, Res Gest. 22.9.4. Aetius, of the so-called heteroousian faction, was also presumed to be a tutor of Julian. The emperor addresses a personal letter to Aetius, recalling him from exile and inviting him to visit him, due to their old acquaintance.

17. Some scholars insist that Eusebius advocated on behalf of Licinius and that this was one of the reasons why Constantine exiled the bishop. Theodoret preserves Constantine's Letter to the Church of Nicomedia (Theodoret, Eccl. Hist. 1.20). In the letter, Eusebius is presented as a co-conspirator in Licinius's tyrannical activities. I am not convinced this was actually written by Constantine but am inclined to see it as a later interpolation to support Theodoret's reconstruction of the past. For a biographical reconstruction of this position, see Gwynn, Eusebians, 117n38. The text is preserved in part in Theodoret, Eccl. Hist. 1.20; and Gelasius of Cyzicus, Eccl. Hist. 1.1-17.

18. For the conflict between Athanasius and Constantius, see chapter 1. 
a successful, even orthodox, career. His beginnings, like many of the enemies of Nicaea we have encountered before, are evident at the very start of his career.

Prior to his flight from Nicomedia, Eusebius is often described as a wanderer. After a brief time as bishop of Berytus, he was appointed to the much larger and significant see of Nicomedia. If this move was not enough to call attention to his questionable character, according to Theodoret, the infamous heretic Arius wrote to Eusebius soon after he was condemned by Alexander in $318 .{ }^{19}$ Eusebius appears to have championed Arius's cause, and he felt the strict disapproval of Alexander soon after. Socrates also preserved Alexander's intense disdain of this meddlesome bishop's tactics: "Eusebius, now bishop in Nicomedia, thinks that the affairs of the church lay under his control. ... He has now established himself at the head of these apostates, daring even to write in all directions in support of them, hoping to drag down some of the ignorant into this shameful and anti-Christian heresy" (Eccl. Hist. 1.6.4). ${ }^{20}$

Eusebius's reception of Arius (and his compatriots) is an obvious reason why later pro-Nicene historians condemned Eusebius. The company one keeps is surely enough reason to dismiss a bishop in flight, as we saw with John Chrysostom. ${ }^{21}$ While this explanation is one of the main reasons why this bishop was so easily maligned, we might look for other reasons why Eusebius's memory would be damned.

Unfortunately, like Eusebius's life, little is known about his actual theological leanings; few of his writings remain, and those that do are suspect, given that they were preserved by his opponents. For instance, his Letter to Arius was found in Athanasius's On the Synod, and Theodoret was responsible for preserving his Letter to Paulinus of Tyre. ${ }^{22}$ It is also telling that a questionable text titled Letter of Recantation makes it into Socrates's Ecclesiastical History along with a handful of sayings that made it into Sozomen's account. ${ }^{23}$ What we are able to discern is that this bishop, like Athanasius, found himself the victim of exile in the aftermath of Nicaea. And he, too, returns to his episcopal post as a triumphant victor. And when he did return, Eusebius's life and career swiftly took off. He was entrusted with the coveted Constantinopolitan bishopric in 338, and then he died a natural death a few years later, in 342. By all accounts, Eusebius had a resoundingly successful career.

19. Theodoret preserves a letter presumably written by Arius to Eusebius in 319 (Eccl. Hist. 1.3, 4). He argues that the letter serves as proof of Alexander's report of Arius's tactics and circle of heretical supporters.

20. The letter is preserved as Letter of Alexander of Alexandria to all Bishops. Translation: NFPF2 $2.3-5$.

21. See chapter 4 .

22. Letter to Arius (CPG 2046); Letter to Paulinus of Tyre (CPG 2045). His other writings that survive are Letter to the Council of Nicaea (fragment, CPG 2047) and Letter of Recantation of Eusebius and Theognis of Nicaea (CPG 2048).

23. Letter to the Council of Nicaea (CPG 2047) and Letter of Recantation of Eusebius and Theognis of Nicaea (CPG 2048). 
What continues to stand out when assessing the history of this particular bishop in flight is the insistence of linking Eusebius to Nicomedia. Not only was Eusebius the one who baptized the emperor on his deathbed, but Eusebius was also appointed the bishop of Constantinople. Why, then, is Eusebius remembered as a heretic rather than as an orthodox bishop? If we move beyond an overtly doctrinal and theological reconstruction (although these details do and will play a role) and look instead at the spatial arguments, we might begin to see how this process plays out in the minds of later writers. Before we turn to those reports, we will examine how an anti-Nicene historian insisted we remember Eusebius. Philostorgius of Cappadocia reveals the stakes involved in remembering Eusebius as either a failed or successful bishop. In his version of events, Philostorgius revives Nicomedia and reminds his readers that this city remained the space of imperial and ecclesiastical power well into the fourth century. ${ }^{24} \mathrm{His}$ presentation of Nicomedia as an important city and Eusebius as a hero points to the various rhetorical strategies deployed by other ecclesiastical historians to downplay the success of both.

\section{HOW TO REHABILITATE A BISHOP: PHILOSTORGIUS OF CAPPADOCIA'S ECCLESIASTICAL HISTORY}

Of all the ecclesiastical historians in the aftermath of Nicaea, Philostorgius of Cappadocia provides us with a rare glimpse into an alternate vision of Christian history. ${ }^{25}$ While his voice ought to be critically evaluated alongside the voices of his contemporaries, he does present a different view of interparty politics and an alternative character evaluation of the major players involved in the controversy. For example, Constantine does not come across as the infallible hero in Philostorgius's account. Instead, we hear of an unpredictable character willing to put to death his firstborn son, Crispus, and second wife, Fausta, as well as exhibit an intense sense of paranoia. ${ }^{26}$

24. All of our authors made note of the earthquake that devastated the city. Nicomedia was eventually rebuilt and appeared to remain an important strategic location for waging military campaigns, but in the minds of pro-Nicene Christian historians, it never regained its former glory. A recent archaeological research team under the support of the Scientific and Technological Research Council of Turkey (TÜBİTAK) and lead by Tuan Sare Agturk has resulted in some fascinating discoveries at the ancient site of Nicomedia and modern-day Izmit. These include sculpted colorful relief panels that reveal a lively and flourishing metropolis in the fourth century. Belke also notes that Nicomedia was the location of one of Asia Minor's three mints and remained a valuable port city for trade throughout late antiquity.

25. For notes on the problems related to the manuscript, see Amidon, Philostorgius, xxiii-xxv.

26. Philostorgius says that Crispus (or Pricus) was killed due to an illicit relationship (or false accusation of one) with Constantine's second wife, Fausta, who is eventually caught in adultery with another man (presumably not Crispus), is killed by being suffocated to death in a sealed bath. See Philostorgius, Eccl. Hist. 2.4. 
As an ardent defender of an anti-Nicene contingent, Philostorgius has been frequently dismissed. Thomas Ferguson has recently made significant headway in advancing our understanding of this historian. ${ }^{27}$ Philostorgius appears to have composed his Ecclesiastical History in Constantinople between 425 and 433, and he catalogues events between 320 and 425. And in his retelling of the immediate aftermath of Nicaea, Eusebius's exile lasts for three years (Eccl. Hist. 2.7). When Eusebius was eventually recalled by Constantine, we see a reversal in the Nicene tide: Alexander was cast out of Alexandria, and Eustathius was expelled from Antioch. ${ }^{28}$ To emphasize the significance of this change, Philostorgius proclaims Eusebius was soon after awarded the bishopric of Constantinople (Eccl. Hist. 2.10). To add to this auspicious event, the remains of the martyr Lucian were discovered by the emperor's mother, Helena, at the bay of Nicomedia (Eccl. Hist. 2.12). Philostorgius is careful to stress that Lucian was the patron saint of Eusebius throughout his career and is undoubtedly the reason why the bishop was able to round out his career in Constantinople.

Another hero is repeatedly lauded in this text alongside Eusebius. Constantius II, unlike his father, was the preferred imperial protagonist in Philostorgius's account. The working relationship between Eusebius and Constantius provides the historian with a poignant narrative twist. After Constantine fell ill, in the thirty-second year of his reign, he blamed his brothers for poisoning him (Eccl. Hist. 2.16). While on his deathbed, Constantine called Eusebius to his side and entrusted him with a letter describing the plot against his life. His letter was to be given to his favored son, Constantius (and not the eldest son, Constantine II), along with his will in order to bring his killers to account.

To further extol the favored son's virtues, Philostorgius remarks that it was Constantius, in control of the eastern empire, who erected the Great Church in Constantinople and transferred the bones of Andrew, Luke, and Timothy to the sanctuary (Eccl. Hist. 3.2). Most importantly, Constantius was responsible for deposing Eusebius's archenemy, Athanasius. Even after Athanasius manipulated the youngest son of Constantine, Constans, and secured his return, Constantius was not fooled but saw right through Athanasius's duplicitous character. The emperor's decision to replace Athanasius with George of Cappadocia was a defining moment and a decisive victory (Eccl. Hist. 3.3). ${ }^{29}$ For Philostorgius, a great deal of good could come from Cappadocia. ${ }^{30}$

27. Thomas Ferguson, The Past Is Prologue: The Revolution of Nicene Historiography (Leiden: Brill, 2005). Joseph Bidez has also careful reconstructed the pieces of this history; see Philostorgius, Kirchengeschichte: mit dem Leben des Lucian von Antiochien und den Fragmenten eines arianischen Historiographen, ed. Joseph Bidez (Berlin: Akademie, 1913).

28. For a description of Eustathius's exile, see chapter 3.

29. Gregory of Cappadocia is not mentioned here, and Amidon (Philostorgius, 39n6) suggests this was a chronological mix-up.

30. Cappadocia, like Nicomedia, would be a flag for nefarious activity. See chapter 1 for a discussion of how Athanasius's episcopal replacements are frequently referred to as Cappadocians and the significance of their outsider status. 
The emperor's constant vigilance ensured that a homoiousian position was upheld. For instance, Constantius called for two councils to settle the matter: one in the West, at Rimini, and one in the East, at Nicomedia. Here we learn about a devastating earthquake in Nicomedia, which prevented the council from taking place. ${ }^{31}$ This divinely inspired event was allowed to happen, according to Philostorgius, because too many bishops present were in favor of the consubstantialist doctrine (Eccl. Hist. 4.10-11). The Eastern Roman Empire was thus saved from a decisive Nicene victory.

Let us zero in on a few details that will occupy us for the remainder of this chapter. First, Philostorgius depicts Eusebius as an orthodox bishop whose exile and return reinforced this claim to orthodoxy. He was persecuted for a brief time but returned triumphant. The brevity of his exile and the success of his career as the celebrated bishop of Constantinople served as further proof of this claim. Second, Constantine appears to have chosen Eusebius as his confidant to deliver his letter revealing the cause of his death to Constantius II. Eusebius was clearly a trustworthy man, according to Philostorgius. Finally, the cause of Nicomedia's destruction was a strong pro-Nicene contingent in the city. These points depart significantly from those preserved in the histories of our pro-Nicene authors, and they tell us a great deal about how these historians deal with the same evidence.

One story, however, is left out of this narrative: Eusebius does not baptize Constantine, even though Philostorgius does confirm that the emperor died in Nicomedia. For this anti-Nicene historian, Eusebius's success was not determined by his relationship with Constantine. That privilege is passed to the emperor's true heir and defender of orthodoxy, Constantius..$^{32}$ Philostorgius nonetheless stresses the significance of Nicomedia as the space and place where Eusebius's identity and authority was secured. Ecclesiastical historians on both sides of the Nicene debate were reluctant to let go of this spatial link. The question remains: why was the destruction of Nicomedia so important to the history Christianity? As we will soon discover, it had a great deal to with Constantinople.

\section{HOW TO CONDEMN A MODEL EXILE: SOCRATES OF CONSTANTINOPLE'S ECCLESIASTICAL HISTORY}

The life of Socrates Scholasticus remains a mystery, much like that of Eusebius. What we learn of it is pulled directly from his Ecclesiastical History. ${ }^{33}$ This major work was composed in Constantinople, where the author was born and raised

31. For discussion of the use of earthquakes in the ecclesiastical historians of the fifth century, see Edward Watts, "Interpreting Catastrophe: Disasters in the Works of Pseudo-Joshua the Stylite, Socrates Scholasticus, Philostorgius, and Timothy Aelurus," Journal of Late Antiquity 2, no. 1 (2009): 79-98.

32. Theodoret, Eccl. Hist. 1.30, mentions that Constantine was baptized on his deathbed but, like Philostorgius, does not mention that it was Eusebius who baptized him. Given Theodoret's theological leanings, we might conclude that he omitted this for different reasons than Philostorgius.

33. Greek text: P. Maraval and P. Périchon, SC, Socrate de Constantinople, Histoire ecclésiastique (books 1-7), SC 477, 493, 505, 506 (2004-2007). Trans. NPNF2. 
(Socrates, Eccl. Hist. 5.24; 5.16) and covers the period from 325 to 439 . The early chapters begin with Constantine's journey to Christianity and his defeat of its known persecutors. After the death of Licinius, Constantine was faced with a new challenge: Arianism, that more dangerous enemy, threatened to infect the entire empire. This heresy, like the persecutions only recently put down, spread like fire and would be the most significant threat to the church. Socrates writes:

And thus from a little spark a large fire was kindled, for the evil which began in the Church at Alexandria ran throughout all Egypt, Libya, and the upper Thebes, and at length diffused itself over the rest of the provinces and cities. Many others also adopted the opinion of Arius, but Eusebius, in particular, was a zealous defender of itnot he of Caesarea, but the one who had before been bishop of the church at Berytus and was then somehow in possession of the bishopric of Nicomedia in Bithynia. ${ }^{34}$

According to Socrates, the Arian heresy, although the invention of a deviant presbyter, could not have succeeded without the help of Eusebius of Nicomedia. As we pointed out above, the letter from Alexander of Alexandria is preserved in the very early stages of the composition of this ecclesiastical history, in which Alexander describes Eusebius as the lead instigator of the Arian faith. He is the "head of these apostates" (Socrates, Eccl. Hist. 1.4).

In this reconstruction of events, Nicomedia stands in direct contrast to the orthodox spaces outside its boundaries. It serves as the touch point for where the most horrific events have and will continue to take place and for where persecution is indistinguishable from heresy. Here we will focus on a few compelling spatial elements in Socrates's narrative. Whenever Constantine is found in Nicomedia, his presence there is only temporary. For example, we first hear of Constantine stopping in Nicomedia when he is first made aware of the dispute between Arius and Alexander (Eccl. Hist. 1.7). We then learn of Eusebius's exile from Nicomedia along with his supporters such as Theognis of Nicaea, Maris of Chalcedon, Theonas of Marmarica, and Secundus of Ptolemais (Eccl. Hist. 1.8).

Socrates reluctantly admits that Eusebius and the even more mysterious Theognis were in exile only for a short while, because they recanted their position. A preserved letter declares that both men supported the term homoousios, although Socrates makes it clear that this is a blatant lie, one meant to ensure their return. He then goes on to supply a number of other letters that promote more confusion than clarity. One letter is conspicuously absent in its entirety, although Socrates relays its most significant contents. The letter, addressed to the Nicomedians by the emperor, states: "Writing to the Nicomedians against Eusebius and Theognis, he [Constantine] censures the misconduct of Eusebius, not only on account of his Arianism, but also because, having formerly been well affected to the ruler, he had 
traitorously conspired against his affairs." (Eccl. Hist. 1.9). ${ }^{35}$ Here Socrates stresses that Constantine was no fool. He was fully aware of Eusebius's dubious behavior. But this absent letter is not how Socrates's version of the following events actually unfolds. Time and again, to his chagrin, the evidence appears to support rather than condemn the infamous bishop.

To distract his readers, Socrates turns to yet another letter in which Eusebius and Theognis explicitly state-and, we are therefore to conclude, falsely claimwhy they did not subscribe to Nicaea's anathemas: "We did not subscribe to the anathematizing; not as objecting to the creed, but as disbelieving the parties accused to be such as was represented, having been satisfied on this point, both from his own letters to us, and from personal conversations" (Eccl. Hist. 1.14). Here Eusebius and Theognis argue that they were guilty of trusting Arius and his party, who had fled to Nicomedia for sanctuary.

In a curious move, Socrates notes that Arius was recalled from exile before Eusebius or Theognis. Arius, however, was not permitted to return to Alexandria. Socrates stresses: "This is evident from the fact that he afterward devised a way to return for himself both into the church and into Alexandria, by having made a fictitious repentance, as we shall show in its proper place" (Eccl. Hist. 1.14, emphasis mine). As we saw in the previous chapter, to return under your own volition was unwise in the best of circumstances. Illegal return ensured one's condemnation and was an explicit act against the church. Socrates makes it clear that no matter the reasons for Arius's return - and, eventually, Eusebius's return as well-both men confirm their guilt in their illegal action. According to Socrates, once a heretic, always a heretic.

To ensure this guilty verdict, Socrates expends a great deal of energy condemning not just the bishop in flight but the city Nicomedia to further elevate Constantinople. He stresses that, from early on, Constantine's support of Christianity was intimately tied to his building campaigns:

After the synod, the emperor spent some time in recreation, and after the public celebration of his twentieth anniversary of his accession, he immediately devoted himself to the reparation of the churches. This he carried into effect in other cities as well as in the city named after him, which being previously called Byzantium, he enlarged, surrounded with massive walls, and adorned with various edifices; and having rendered it equal to imperial Rome, he named it Constantinople, establishing by law that it should be designated New Rome. This law was engraved on a pillar of stone erected in public view in the Stregium, near the emperor's equestrian statue. He built also in the same city two churches, one of which he named Irene; and the other, The Apostles. (Eccl. Hist. 1.16, emphasis mine)

35. In a side note, that is amusing, though also altogether frustrating, to contemporary historians trying to piece together Socrates's evidence; he writes: "But I thought it would be superfluous to insert here the letters respecting these things, because of their length; those who wish to do so may find them elsewhere and give them a perusal. This is sufficient notice of these transactions" (Eccl. Hist. 1.9). The modern reader will just have to take his word for it. 
In this instance, it is not just the walls of the church that make Christians, but the walls of the city, along with its edifices, statues, pillars, and two great churches. ${ }^{36}$ The reconstruction of Constantinople as a holy city was reliant upon the transference of holy relics to the center of the city. These choice items were reportedly discovered by Constantine's mother, Helena, during her pilgrimage across the empire. Socrates is careful to note that the most significant find of all was the holy cross. While a piece remained in Jerusalem, Helena sent the remainder of the true cross to Constantine, who preserved its remaining pieces in his statue in Constantinople: "The other part she sent to the emperor, who, being persuaded that the city would be perfectly secure where that relic should be preserved, privately enclosed it in his own statue, which stands on a large column of porphyry in the forum called Constantine's at Constantinople" (Eccl. Hist. 1.17). The large column houses the memory of Christ transplanted in Constantinople both to spread a proNicene Christianity and to solidify Constantine's memory as an orthodox one. His very image protects the faith.

Socrates then turns his attention back to Nicomedia. As he describes it, a war had been waged within the empire. After Eusebius of Nicomedia's return from exile, he, along with his henchman, caused even greater mischief than before. Not only are these men infected with the Arian heresy, but they make it their main objective to ensure others become infected as well. To do so, they attempt to secure Arius's return to Alexandria from Nicomedia. Eusebius first writes to Athanasius asking him to readmit Arius. Athanasius, of course, refuses the request, and Eusebius subsequently appeals directly to the emperor. His appeal is initially rejected, but we learn that Eusebius eventually worms his way into the emperor's favor by an alternate route.

As with most heretics, women are the conduits of corruption, and Eusebius decides to target Constantia, the emperor's sister. He does this by soliciting the help of an unnamed presbyter sympathetic to Eusebius's cause. ${ }^{37}$ Socrates reminds his readers that Constantia is the widow of Licinius, the last known imperial persecutor of the faith. A questionable character indeed, not unlike Eudoxia, whom we discussed in the previous chapter.

The unnamed presbyter succeeds in winning Constantia's sympathies and, upon becoming gravely ill, she appeals to her brother, who, in a touching moment, returns to Nicomedia to be by her side. On her deathbed, she appeals to her brother and asks him to trust her new advisor. She inevitably dies from one cause

36. See chapter 1 for reference to Augustine's quote, "Do walls then make Christians?" and compare with Ps.-Martyrius's claim that a city is made holy only by the men who inhabit them, discussed in chapter 4.

37. On the importance of Constantia's role in creating social networks, see Julia Hillner, "FifthCentury Church Historians: Social Network Analysts Before Their Time?” Migration of Faith (blog), April 1, 2016, www.hrionline.ac.uk/sites/clericalexile/2016/04/o1/fifth-century-church-historians-social-network-analysts-before-their-time. 
or another, and we might conclude that there was a divine hand in this imperial death as well. Constantine, in his grief and under the influence of his Nicomedian surroundings, unwisely trusts the Nicomedian presbyter. This unnamed gobetween continues to advocate on behalf of Arius, who is eventually able to return to Alexandria with a letter of imperial support in hand.

Ever the orthodox defender, Athanasius predictably refuses to admit Arius back into the church. Constantine, not one to back down from a challenge, threatens to exile Athanasius in return. Seeing their opportunity, the partisans of Eusebius continue to sway the emperor during his stay in Nicomedia. The Eusebians then conspire with the Melitians and begin to invent charges against Athanasius. Fortunately, Athanasius has a few supporters present in Nicomedia who alert the emperor to their plan. After an initial reprieve from the emperor, despite the imperial letter of support in hand, Athanasius finally has a charge of treason brought against him. Constantine then arraigns a council at Tyre to settle the matter once and for all..$^{8}$ It remains unclear whether Constantine removed himself from Nicomedia at this point, but the damage had been done. The readers-and Athanasius-find themselves soon focused upon Tyre.

Athanasius, suspicious of this turn of events, was appropriately hesitant to attend this council. When he did arrive, he remained there only long enough to point out the absurdity of the charges brought against him. In a particular humorous scene, the Melitian representatives accuse Athanasius of murder and present a severed hand as evidence. The charge was soon dismissed when Arsenius, previously believed to be dead, was found in the audience observing the spectacle. Socrates gleefully reports: "Then addressing himself to those present, he [Athanasius] said, 'Arsenius, as you see, is found to have two hands: let my accusers show the place whence the third was cut off'" (Eccl. Hist. 1.24).

Eusebius and his supporters were not so easily dissuaded and state that Athanasius may not have had a hand in killing Arsenius, but he was guilty of tampering with the grain trade. This second charge was enough to scare any man, and Athanasius fled to Constantinople. The Eusebians, hot on his trail, brought with them the same charges of treason. The result, as we have already discussed, was Athanasius's first exile, spent in Gaul. Notably, in this text, Athanasius was sent to Gaul from Constantinople. Athanasius was not the first bishop to flee to and from Gaul. As we may recall, Eusebius was also exiled to Gaul, but from Nicomedia. These spatial details are not insignificant, as we will soon see.

Socrates then turns his attention to Arius in a moment of reflection. After Arius returned to Alexandria, he stirred up trouble and was forced to flee yet again, this time to Constantinople, where another Alexander awaited him. Compelled by both the Eusebians and Constantine, Alexander was forced to readmit Arius to the church, but the very presence of the heretic divided the city. Eusebius of 
Nicomedia promised that if Arius was not readmitted, the current bishop of Constantinople would be deposed; under the threat of this promise, Alexander spent a night in prayer in the holy church of St. Irene, recently built and dedicated to Constantine. Arius and his supporters, meanwhile, paraded through the center of Constantinople to celebrate winning over the emperor and being readmitted to the church. As he passed the porphyry column, Arius was struck with an intense pain in his stomach. He quickly retreated to a privy and, in a more detailed account of his demise than even Athanasius could dream up, died an ignominious and very public death. ${ }^{39}$ This column, upon which sits the image of Constantine, was where the remains of the true cross were hidden. While Arius may have been able to fool the real emperor in Nicomedia, he was unable to fool the emperor's holy likeness in Constantinople. As Socrates points out, the statue and the cross were of the same substance. And it was under the emperor's image in the likeness of the divine that the heretic was ultimately exposed.

The battle did not end there. The stones of Constantinople were now infected with the disease of heresy, along with the stench of Arius's memory. Not even the emperor was immune. Constantine soon became ill, and Socrates reports that the emperor left Constantinople to seek out the healing baths of Helenopolis. But the soothing waters were not enough to wash away his illness, so the ailing emperor traveled to Nicomedia. Socrates is careful to note that this brief stop was not the city center of Nicomedia, but one of the surrounding suburbs. It was there that the emperor was finally baptized and died, safely away from the scent of heresy. In Socrates's account, there is no mention of Eusebius's hand in this baptism, but the proximity to the cursed city continued to linger.

Socrates's narrative clearly departs from Philostorgius's account, examined above. Socrates, for example, says that Constantine entrusted his will not to Eusebius but to an unnamed presbyter, who was charged with delivering it to Constantius II. We might recall that Philostorgius's version of Constantine's illness credits an act of poisoning by one of Constantine's brothers. Socrates, on the other hand, seems to insinuate that Constantine's illness had more to do with Arius and his demise than with any plotting relative. It was only after his final acceptance of Nicaea and baptism - not by Eusebius of Nicomedia - that Constantine died. But Constantine's memory, like the cross in Constantinople, must be preserved.

The streets of this new Rome had yet to be cleaned, and this is where book 2 of Socrates's Ecclesiastical History returns to the battle for Nicene Christianity. Alexander of Constantinople died soon after Constantine, and it appears as if both church and empire were doomed. Two successors were proposed: Paul, who was supported by a pro-Nicene contingent, and Macedonius, who was supported by the so-called Arians in Constantinople. But both were rejected by the new

39. For a detailed examination of Arius's death in Socrates's Ecclesiastical History, see Muehlberger, "Legend of Arius' Death," 15-18. 
emperor of the East, Constantius II. As we already know, Eusebius of Nicomedia was appointed the archbishop of Constantinople instead.

His first act, which should now sound familiar, was to intervene in Antiochene and Alexandrian affairs. Eusebius immediately convened a synod at Antioch, under the pretense of dedicating the church that the father of the Augusti had commenced, which his son Constantius had finished in the tenth year after its foundations were laid. But his real intent was to subvert and abolish the Nicene doctrine.

In a revealing move, Socrates takes us back to the beginning and reminds us of Athanasius's identity as an exile. All may appear lost, but a return has yet to come. At this point, after the death of Constantine, Athanasius triumphantly reentered Alexandria. Eusebius, aghast at this bold move, called for his second exile and sent his replacement, Gregory of Cappadocia, to Alexandria. Here Socrates slightly alters the story for his own purposes, departing from the details provided by Athanasius in the texts we have already explored. ${ }^{\circ}$ Athanasius, hidden in the midst of his congregants, who were singing psalms, escaped the notice of his would-be captors and fled at once to Rome. It was only after he escaped that Gregory set the Great Church of Alexandria on fire-it is as if the fires of the Great Persecution in Nicomedia had begun once again.

It is this second flight and the climatic moment in Alexandria that marked the end of Eusebius's life. Socrates's description is neither graphic nor detailed. Eusebius does not earn the spectacle of death that Arius had previously provided. We simply hear that Eusebius did not live long enough to hear of the bishop of Rome's support for Athanasius and he simply "died a short time after the Synod was held." (Eccl. Hist. 2.12). The story then quickly passes on to a continued battle over the Constantinopolitan episcopacy. Eusebius's momentary control of Constantinople is overshadowed in Socrates's account by the momentous safe return of Constantine's exhumed body to Constantinople..$^{41}$

As we have seen, Eusebius must be remembered as the bishop of a cursed landscape and not the space of pro-Nicene Christian orthodoxy. And even though Eusebius died in Constantinople, his memory is returned to Nicomedia, just as Constantine's body is transferred back to that holy city. The damning of Nicomedia reinforces how space and place dictate Nicene orthodoxy and immortalized itself in Constantinople.

To briefly summarize, both Athanasius and Eusebius experienced exile and then went on to have successful careers. Eusebius of Nicomedia, like Athanasius,

40. See the previous examination of Athanasius's Defense before Constantius and Defense of His Flight in chapter 2 and his Encyclical Letter in chapter 4.

41. Barnes argues that Constantinople was not simply built on top of Byzantium, but that Byzantium was completely leveled by Constantine; see Barnes, Constantine and Eusebius, 113. Although a relatively insignificant port town, Byzantium was protected by Diocletian during the Gothic raids and then fortified against Maximinus in 311. 
spent a brief time in retreat, followed by a triumphant return. After his exile, he went on to live out an influential and successful career marked by two crowning achievements: he baptized Constantine on his deathbed (although Socrates distances Eusebius from this honor) and was then awarded the coveted bishopric of Constantinople (Socrates, Eccl. Hist. 2.7; Sozomen, Eccl. Hist. 3.4). What we find here is, for all intents and purposes, the makings of an orthodox exile. Yet Eusebius's exile would not be remembered as a testament to his piety. If elaborated on at all, it was used as proof of his guilt, with the noted exception of Philostorgius.

As we have examined here, these two successful bishops fled and returned to different spaces, which would play a significant role in how they would be remembered. Eusebius returned to the space from which he was first exiled, Nicomedia. According to Socrates, Athanasius was initially exiled from Constantinople. And like Constantine, his memory would later be revived and moved to Constantinople, just as Constantine's body was after his death.

Other ecclesiastical historians of the fifth century would go on to damn the Nicomedian landscape and everyone associated with it, as it transformed from a location of imperial persecution, as described by Lactantius and Eusebius of Caesarea, to one infected with heresy, as Socrates envisioned it. In the memorymaking process of the champions of Nicene orthodoxy, Nicomedia's failure was Constantinople's success. Eusebius, that failed bishop, was safely (re)placed where he rightfully belonged. The ecclesiastical historians altered the way in which exile was read, as well as how the spaces and places from which bishops were exiled ought to be remembered. As we have argued here, they did so in order to shape how we tell the heroes from the villains, particularly in those moments when it is not entirely clear who is who. Some spaces were just too powerful to erase. In order to damn the man, we learn, you must also damn the city. At the moment when Eusebius's story concludes and the city of Nicomedia is condemned, another battle of episcopal thrones take place, not in Constantinople, but in the strategically significant location of Antioch.

\section{HOW TO REHABILITATE A CONDEMNED \\ CITY: THEODORET OF CYRRHUS'S ECCLESIASTICAL HISTORY}

All the pro-Nicene historians we have examined throughout this book so far remark that Eustathius, a noted supporter of Athanasius, was targeted by Eusebius of Nicomedia after the Council of Nicaea. Along with his active role in Athanasius's deposition at the Council of Tyre in 335 and the reinstatement of Arius at the Synod of Jerusalem in 335, Eusebius played an important role in the Antiochene politics that would later shape Meletius of Antioch's political life, which will occupy us in the next chapter. Pro-Nicene followers of Eustathius, however, were critical of Athanasius and were subsequently labeled "Arians." Christine 
Shepardson helpfully summarizes the series of events: "In these decades, Antioch hosted a series of councils that attacked Athanasius's theology and authority and the orthodoxy of the Nicene council. Eastern bishops, following Eusebius of Nicomedia, met in Antioch in the winters of 337-338 and 338-339 in efforts to enforce Athanasius's deposition, which the Council of Tyre had advocated in 335 ." $^{42}$ These councils ostensibly allowed for a more ambiguous definition of the Nicene Creed, which enabled Eudoxius, a strongly so-called heteroousian-leaning bishop, to gain hold of the Antiochene see, although he, too, was temporarily exiled in 358 . As a rival, Eudoxius was also named bishop of Constantinople from 360 to 370. Although Eustathius supported Athanasius, the majority of the leaders in Antioch were staunch opponents. ${ }^{43}$ Would this city, alongside Nicomedia, be condemned as well? If John Chrysostom's life and career tell us anything, the answer must be a resounding no. Antioch, and the spaces and places of Nicene orthodoxy, also played a role in further damning Nicomedia and its bishop in an effort to preserve and promote Constantinople.

Theodoret of Cyrrhus, a man who also would find himself in flight, composed his history of the church between 425 and 428, while he was still actively invested in the Antiochene community where he was born and raised (b. 393). Although he was the (reluctant) bishop of Cyrrhus, many have noted his frequent visits to his hometown of Antioch. ${ }^{44}$ Many of Theodoret's modern biographers state that he was heavily influenced by John Chrysostom and the Antiochene bishop Flavian. ${ }^{45}$ Theodoret's episcopal career, like that of many of the bishops we have studied, was also immersed in and defined by controversy. Theodoret was exiled from 449 to 451 due to his involvement in the Christological controversies that occupied the remainder of the fifth century. Most recent scholarship has, therefore, focused on his involvement in the Nestorian controversy, which once again pitted Antioch against Alexandria and was the source of his many troubles. Instead of moving too far along into his episcopal career and the theological debates that occupied him there, we will focus on his preservation of a pro-Nicene legacy in his earlier work. Specifically, we will examine his exilic discourse on Eusebius of Nicomedia to reinforce the spatial arguments we have explored so far. Theodoret's spatial politics, much like those of Socrates, are key to his memory-making enterprise.

42. Shepardson, Controlling Contested Places, 489. Cf. Ayres, Nicaea and Its Legacy, 174-76, 226-28.

43. This may be one of the chief reasons why Gregory of Nazianzus attempted to reintroduce Athanasian orthodoxy through his panegyric. See chapter 1.

44. For a recent investigation of Theodoret and his social network, see Adam Schor, Theodoret's People: Social Networks and Religious Conflict in late Roman Syria (Berkeley: University of California Press, 2011), 19-39. For a thorough investigation of Theodoret's life, see Theresa Urbainczyk, Theodoret of Cyrrhus: The Bishop and the Holy Man (Ann Arbor: University of Michigan Press, 2002), 11-28.

45. As in the case of Socrates, knowledge of Theodoret's life stems mostly from his own works; see P. Canivet, Le monachisme Syrian salon Théodoret de Cyr., ThH 42 (Paris: Beauchesne, 1977), 37-63. 
Theodoret does not start with the council of Nicaea, like the other pro-Nicene historians we have examined. Instead, he zeroes in on the city of Alexandria and the birth of the Arian controversy. After describing a number of heresies that plagued this city, he then presents a list of trustworthy bishops along with a series of letters exchanged between each of these men to verify their legitimacy. It is quite striking that Alexander of Alexandria and Alexander of Constantinople are twin pillars of orthodoxy at the start of this narrative. According to Theodoret, pro-Nicene orthodoxy was already firmly rooted in both locations even before the council took place. Their example and alliance paved the way for their staunchest supporter and chief protagonist, Athanasius, who would stop at nothing to see their vision of orthodoxy fully realized across the rest of the empire.

The fiercest battle, however, took place in that city stuck in the middle, between these twin pillars: Antioch. In this account, we see how Eusebius of Nicomedia becomes the literary foil to Athanasius's every move. Theodoret claims that, like Arius, "he too vomited forth his own impiety" (Eccl. Hist. 1.4). It is not from Nicomedia that Eusebius will do the most damage, but from Antioch.

Before Theodoret turns to Antioch, we learn a great deal more about Eusebius's duplicitous nature and wandering habits. He too reaffirms Eusebius's prior appointment at Berytus and his penchant for spreading discord across the eastern empire. Theodoret also champions Constantine as a savior king. And like Eusebius of Caesarea, Theodoret describes Constantine as a well-intentioned emperor who was, unfortunately, easily deceived by false Christians such as the Eusebians. The emperor, however, would soon see through to Eusebius's true nature once Arius and his followers fled to Nicomedia. Eusebius was condemned and banished to Gaul not just because he protected heretics but also because he openly participated in their evil deeds. As we now know, this exile was only temporary. Theodoret concludes: "But the exiled bishops, employing their customary artifices, abused the benevolence of the emperor, renewed previous contents, and regained their former power" (Eccl. Hist. 1.19). And similar to what we find in other accounts, Eusebius's persuasive powers eventually resulted in his gaining control of Constantinople. It is this move-which was passed over quickly by Socrates-that Theodoret singles out as the true cause behind Eusebius's influence over Antiochene politics.

Much like Sozomen, with whom we will engage in more depth in the next chapter, Theodoret describes Eustathius-the first to experience exile from his episcopal post in Antioch-as the victim of the Eusebian (read: Arian) efforts to infect the empire by way of this strategic city. ${ }^{46}$ On his way to Constantinople, on the emperor's dime, Eusebius and his compatriot and fellow former exile, Theognis, stop temporarily in Antioch. While there, they stir up trouble and frame Eustathius by recruiting a woman of ill repute to accuse him of fathering and then abandoning her child. No other witnesses are brought forth, and Eustathius is condemned and banished to 
Illyricum. Thus began a fierce battle over Antioch's episcopal see. A series of Arians take hold of it but are unable to maintain control for any extensive period. After this woman of ill repute was struck with an illness - a story we have heard before-she confesses to her crime, and Eustathius's reputation was preserved. But the damage had been done, and Eustathius did not return. The outcome was a series of bishops competing for control of Antioch, which bound Alexandria to Antiochene politics and would be the source of significant strife from around 326 through 415 .

This fierce competition in Antioch preoccupies the entirety of book 2 of Theoderet's Ecclesiastical History. Theodoret's discourse on Christian flight was thoroughly shaped by Athanasius's account in his Defense of His Flight. ${ }^{47}$ He includes direct excerpts from the text to amplify his case. Time and time again, the cause of exile is characterized as the handiwork of the enemies of Athanasius and his supporters. There are no tactics they will avoid to dupe an emperor, slander righteous men, or chase saintly men out of their cities, only to murder them later. It was only natural, then, that the defenders of Nicaea flee to escape these power-hungry enemies of the true church. Yet heretics also flee. And their unholy flights, Theodoret insists, are evidence of their guilt (Eccl. Hist. 2.6). What, then, determines whether a bishop's flight is orthodox? According to Theodoret, it is one's dealings with Antioch.

Like Socrates, Theodoret is bound by spatial politics, but his dealings with heretical exiles start and end with his hometown. His heresiological conclusions are further challenged by another fleeing bishop, Meletius of Antioch, whom we will explore in greater depth in the following chapter. For now, it is enough to say that Theodoret, like Socrates, condemned Eusebius of Nicomedia precisely because his exile did not match up to Athanasius's many flights. His further involvement in Antiochene politics only confirmed this point.

\section{CONCLUSION}

Nicaea's legacy was crystalized in the ecclesiastical histories composed during and after the turn of the fifth century. Although Eusebius of Caesarea skirted around many of the theological battles waged between pro- and anti-Nicenes soon after the famed council, the fifth-century writers we encountered in this chapter took a different approach, recounting for their readers all the harried details that occupied the majority of the fourth century. But as we have begun to see, each historian shaped the past to meet the needs and demands of his own historical moment. And in the writings of the fifth-century authors explored here, Nicaea's victory was already assumed, and a Christian empire, however imaginary, was firmly in place. ${ }^{48}$

47. See discussion in chapter 2.

48. Lim also focuses his attention on other ecclesiastical historians are also writing around this period, including Rufinus of Aquileia and Gelasius of Cyzicus; see Lim, Public Disputation, 209-13. In 
These later writers often relied upon the writings of Athanasius as well as other heresiologists to reconstruct their version of the pro-Nicene story. ${ }^{49}$ And in their most revealing moments, these historians deviated from earlier narratives (and evidence) to identify and reflect on their contemporary theological and political debates. Socrates, invested in the preservation of a Constantinopolitan vision of orthodoxy, could not allow Eusebius to lay claim to that space. Instead, he must expel the memory of that failed bishop in order to preserve an Athanasian legacy. Theodoret too would preserve an Athanasian memory, but looked to the battle over Antioch to stake his spatial claims. The Christological controversies of Theodoret's day required him to condemn Eusebius and Nicomedia from a more eastern context. As the theological battles shifted further away from Rome, the exiles of the fifth century would continue to shape the literary landscape.

As we saw with John Chrysostom, how and why one flees often determine whether one's exile is remembered as a success or a failure. As a staunch supporter of Arianism, Eusebius of Nicomedia, the triumphant bishop of the East, all but disappears within pro-Nicene Christian memory, only to resurface as an example of nefarious activity against the orthodox church or of how not to flee. When we do hear of Eusebius's exile, it is characterized as a temporary exile and contrasted with the many sufferings Athanasius was forced to undergo. Eusebius was able to return only through deception, and his failure as an exile only proved this duplicity. Eusebius was recalled from exile after he agreed to sign an agreeable confession of faith, although, as the pro-Nicene biographers insisted, only under false pretenses.

Yet Eusebius's subsequent political and ecclesiastical career was a resounding success: he remained a notable confidant of both Constantine and his son Constantius II, he was awarded the bishopric of Constantinople in 339, he presided over the Antiochene synod in 341, and he died of natural causes. His return from exile should be read as triumphant, and it was by at least one-albeit anti-Niceneecclesiastical historian. He not only baptized the emperor but also was rewarded with the episcopal see at Constantinople. But his legacy was not often tied to Constantinople. His memory, like the city of Nicomedia, slowly fades into infamy, the rubble of which contains the most noxious of men never to be resurrected. His identity as a bishop thus remains a contemptuous one in pro-Nicene Christian memory. His ongoing rejection of Athanasian theology confirmed his legacy as a known heretic and staunch persecutor of the true church.

this chapter and the next, I look primarily at Socrates, Sozomen, and Theodoret for two reasons. First, these authors are heavily invested in the construction of an Eastern Roman Empire with Constantinople at the heart of orthodox urban space. Second, Socrates and Sozomen differ in how they preserve John Chrysostom's legacy. Their treatment of Meletius of Antioch, therefore, reveals a great deal about how a pro-Nicene legacy either accepts or rejects Meletius.

49. See chapters 3 and 5 . 
The contentious history of the episcopal succession in and around Constantinople and its links to the conflict in Antioch will continue to occupy us in our final chapter. Like Eusebius of Nicomedia, Meletius of Antioch will continue to call into question whether an exile was or was not deemed orthodox. The next legacy of Christian flight was a much more difficult case to reconstruct as orthodox. Meletius was a man with a sordid past. Would his baptism of John Chrysostom be enough to clear his name? As we have learned with Eusebius, baptism seems to muddy the waters rather than wash away the stains of a questionable past or future. 


\section{6 \\ Remembering Exile}

The ecclesiastical historians of the fifth century complicated the process of remembering clerical exile as they attempted to define the nature and purpose of Christian flight in a post-Constantinian context. A fleeing bishop was hard to define, let alone defend. Eusebius of Nicomedia, whom we examined in some depth in the last chapter, must be (re)placed in the city from which he was exiled to condemn his flight and label him a heretic, while Athanasius of Alexandria was transferred to a recognizably orthodox space to confirm and defend his status as an orthodox hero. Our last case study turns to yet another man in flight, and one we have encountered before, by way of John Chrysostom. Meletius of Antioch is a particularly difficult figure to define precisely because his status as an exile continues to slip beyond pro- or anti-Nicene categories of orthodoxy. He exists in a liminal space within the ecclesiastical histories of the fifth century. This almost-but-notquite-orthodox figure therefore demonstrates how exile further destabilizes the orthodox project.

In this final chapter, we will explore once again how the discourse of exile was used to remember and shape Nicene orthodoxy. And yet, this final bishop in flight had a conflicted legacy. We will then begin where we left off in the previous chapter and, here, examine Theodoret's reconstruction of the Antiochene landscape. In this examination, however, we will pay attention not to the invading bishop, but to Antioch's thrice-ousted bishop, Meletius. We then turn to a more detailed assessment of Sozomen of Constantinople's reconstruction of Meletius's exile and its role in the struggle for orthodoxy not in Antioch, but in Constantinople. Finally, we compare Sozomen to his Constantinopolitan counterpart, Socrates, who was also heavily invested in promoting a pro-Nicene vision in and around this golden city. As we will conclude, this new Rome, this space of imperial Christianity and the receptacle of Athanasian orthodoxy, wrestled with a legacy of episcopal flight because it continued to threaten to undermine the very orthodoxy it sought to reinforce. 


\section{REMEMBERING A NOT-SO-MODEL CITY: ANTIOCH}

Theodoret of Cyrrhus frames his assessment of Antioch by comparing Meletius to Athanasius. We have seen this tactic before. ${ }^{1}$ He sets the stage by describing for his readers how Eudoxius, a noted Arian and a Cappadocian, invaded Antioch and seized the bishopric after the Nicene representative, Eustathius, was ousted (ca. 332). Allusions to the arrival of Gregory and George of Cappadocia in Alexandria after Athanasius was expelled are clearly at play here. ${ }^{2}$ After receiving conflicting advice about this appointment, Constantius II, a dubious character in this text, calls a second council at Nicaea to settle any concerns related to Eudoxius's appointment, along with any debates related to the Nicene Creed. In order to prevent what would have been a theological disaster, Theodoret states that a divinely inspired earthquake, much like the one at Nicomedia, prevented this second Nicene council from taking place. ${ }^{3}$ There appeared to be too much support by known heretics for this to have safely ensured a pro-Nicene victory in Nicaea a second time.

In the aftermath of the earthquake, Eudoxius was successfully expelled from Antioch. His mischief, however, would not end there. The Arian bishop then dared to take control of Constantinople. (Again, Athanasius's dealings with Eusebius of Nicomedia lurk in the background.) Eudoxius's flight to Constantinople leaves Antioch without a bishop. Theodoret then announces that the most holy Meletius, not under his own volition (unlike Eudoxius), was elected as the replacement bishop:

It fell out opportunely that the divine Meletius, who was ruling a certain city of Armenia, had been grieved with the insubordination of the people under his rule and was now living without occupation elsewhere. The Arian faction imagined that Meletius was of the same way of thinking as themselves, and an upholder of their doctrines. They therefore petitioned Constantius to commit to his hands the reins of the Antiochene church. Indeed, in the hope of establishing their impiety, there was no law that they did not fearlessly transgress; illegality was becoming the very foundation of their blasphemy; nor was this an isolated specimen of their irregular proceedings. (Eccl. Hist. 2.27, emphasis mine $)^{4}$

As we learn here, Meletius was elected by an Arian community that believed he would champion their cause. He was awarded the post explicitly for this reason. Meletius went on to win the support of Constantius, and even the Jews and

1. For a description of how Ps.-Martyrius and Palladius revive John Chrysostom's reputation by associating him with Athanasius, see chapter 4.

2. For a description of these two invading bishops from Cappadocia, see chapter 1 .

3. In chapter 5 , I discuss how an earthquake in Nicomedia is used by Socrates as a description of divine justice.

4. Edition: CPG 6222 and L. Parmentier, F. Scheidweiler, and G. C. Hansen, Theodoretus Cyri, Kirchengeschichte, 3rd ed., Griechischen Christlichen Schriftsteller 19 (Berlin: Akademie Verlag, 1998). Translation: NPNF2, 33-159, with some slight modifications. 
non-Christians came out in droves to greet the new bishop. It appeared that Meletius had the support of the entire city. The true believers (that is, the Nicene Christians) knew the true reason God had allowed this man to be chosen. In the same chapter, Theodoret continues:

On the other hand, the maintainers of apostolic doctrine, who were perfectly well aware of the soundness of the great Meletius and had clear knowledge of his stainless character and wealth of virtue, came to a common vote and took measures to have their resolution written out and subscribed by all without delay. This document both parties as a bond of compromise entrusted to the safekeeping of a bishop who was a noble champion of the truth, Eusebius of Samosata. And when the great Meletius had received the imperial summons and arrived, forth to meet him came all the higher ranks of the priesthood, forth came all the other orders of the church, and the whole population of the city (Eccl. Hist. 2.27).

Unbeknownst to the uninitiated, Meletius was actually an orthodox leader, not an Arian ally, so the Nicene community also agreed to this appointment.

Yet Meletius, that arbiter of compromise and secret Nicene agent, was soon cast from his throne, like so many so-called orthodox bishops before him. Theodoret reveals that, in an ill-fated display of his oratory skill, Meletius (purposefully) promoted an analogy of the Trinity that landed him in trouble, because it exposed his Nicene commitments. The Arian community subsequently expelled the bishop and quickly replaced him with the unabashedly anti-Nicene Euzoius. And, predictably, the battle for orthodoxy raged on.

Theodoret's version of Meletius's story clearly reflects his own commitments to an orthodox, pro-Nicene vision of Antioch. By this point, the Meletian faction had won the day. Meletius was an unquestionably orthodox bishop as far as Theodoret was concerned. The bishop's experience of exile looked and sounded a lot like that of Athanasius. But Theodoret's positive assessment of Meletius was far from the consensus. Meletius's legacy remained a highly contested one.

As far as scholars today are able to discern, when Meletius was appointed bishop of Antioch, he was neither a strong advocate for nor a strong opponent of Athanasian theology. ${ }^{5}$ For example, during his lifetime, his election was not recognized by the pro-Nicene community either in Alexandria or in Rome. Even Theodoret must admit that Meletius was exiled almost immediately after he was appointed in 361 ,

5. See Brian Daley, "The Enigma of Meletius of Antioch," in Tradition and the Rule of Faith in the Early Church: Essays in Honor of Joseph T. Lienhard, S.J., ed. Ronnie J. Rombs and Alexander Y. Hwang (Washington, DC: Catholic University of America Press, 2010), 128-50; and Oliver Hihn, "The Election and Deposition of Meletius of Antioch: The Fall of an Integrative Bishop," in Episcopal Elections in Late Antiquity, ed. Johan Leemans, Peter Van Nuffelen, Shawn W. J. Keough, and Carla Nicolaye. Arbeiten zur Kirchengeschichte 119 (Berlin: de Gruyter, 2011), 357-74. Both authors appear to favor the more popular idea that Meletius's theology was a happy medium. I neither make this claim nor entirely refute it. My goal in this chapter is to show how this enigmatic figure, to borrow from Daley's title, came to be remembered in the writings of fifth-century historians. 
which is a conspicuous detail. Yet Meletius also returned under Julian's reprieve and, like Athanasius, found he had been replaced. In this instance, Euzoius, the anti-Nicene champion, and Paulinus, the pro-Nicene Alexandrian hero, had both occupied the city. As far as we know, Athanasius and other powerful bishops in the West recognized Paulinus as the one true bishop. And Richard Flower has made a firm case for the ongoing western influence in Antioch. ${ }^{6}$

And yet it is clear that Meletius continued to influence a competitive Antiochene community, even though he was expelled two more times (365-366 and 371-378). But his firmly pro-Nicene position was remembered only by Theodoret. As we will see, others would not easily agree. The claim to orthodoxy, at least a recognizably Athanasian orthodoxy, appears linked to that climactic moment later historians would frequently hark upon: Meletius's recruitment and baptism of John Chrysostom.

As we explored in chapter 3, the battle over an Antiochene orthodoxy remained a sore spot for John, and it followed him to Constantinople. His relationship with Meletius and his mentorship under Meletius's successor, Flavian, placed John at risk. To state it another way, John's initiation into Christianity under Meletius, specifically his baptism by a possible Arian-or, at the very least, anti-Nicenesympathizer, remained an embarrassing detail for later pro-Nicene writers. This detail was further exacerbated by John's ongoing praise of Meletius. It was John's continued efforts to promote Meletius's legacy of flight that would force later writers to reconcile this relationship. As we will come to see, it took nothing short of a miracle, provided by a long-dead martyr, to restore Meletius to a respectable, albeit still questionable, orthodox register.

Dead or alive, the places from which and to which a bishop was exiled could make or break his orthodoxy. This consequence is most clearly seen in John Chrysostom's assessment of another Antiochene hero to describe how later writers dealt with Meletius's memory. His martyrology On St. Babylas served as a literary model for later writers who were at a loss with what to do with a bishop in flight who was just too difficult to place.

\section{MARTYRS AND BISHOPS IN FLIGHT}

St. Babylas was an important martyr in Antioch, and his posthumous links to Meletius were a rehabilitative force, much as Athanasius's exile would later help restore John to Constantinople. But his memory proved efficacious only to those who inhabited the spaces in and around Antioch. Although the bones of the martyr would frequently move, the martyr would find his final resting place just outside the city limits. Christine Shepardson has provided a thorough investigation of

6. Richard Flower, Imperial Invectives Against Constantius II (Liverpool: Liverpool University Press, 2016), 18-20. 
St. Babylas's story in her book Controlling Contested Places, in which she highlights the significance of the competition over the memory of this saint's relics at a particularly tense moment in Antiochene history. ${ }^{7}$

As we learn in the contemporaneous writings of John Chrysostom, Libanius of Antioch, and the emperor Julian, the bones of Babylas were moved from Antioch to the neighboring territory of Daphne. The bones were then housed in a church built by Constantius Gallus (a nephew of the emperor Constantine), in 354, which eventually became an important religious site for Christians. Daphne was also the location of a famous Graeco-Roman Temple of Apollo and the oracle of Daphne. As we might expect, the two sacred sites eventually clashed.

Each of our authors preserves a version of the following story. After Julian's rise to power in 361, he sought out the oracle at the Temple of Apollo for guidance. After finding the oracle mute, he discovered that the bones of the martyr Babylas were the cause. So Julian ordered that the bones be removed and returned to their original location. The Christian community apparently used the occasion to challenge the emperor and turned the event into a religious parade. The bones were then reburied in the Antiochene city cemetery and became a site of rebellion. ${ }^{8}$ To add further insult to the emperor's efforts to restore the integrity of the temple, it was soon leveled to the ground by a suspicious fire. ${ }^{9}$

John Chrysostom, whose narrative we will explore in greater detail below, preserves our only evidence of Libanius's report on the events preceding and following the fire (John Chrysostom, Or. 60). As Shepardson has noted in detail, Libanius's version demonstrates that this peculiar story remained a sore spot among the non-Christian intellectual elite who lived during and after the event. While Julian's version pits the citizens of Antioch as a whole against the emperor, John and Libanius describe the event as an internal struggle over the sacred history of a city and its sacred places. John would ultimately have the final say on the matter, but all three authors provide us with one revealing detail: the bones of the martyr were returned to the heart of the city. Let us examine why this spatial detail is significant for our understanding of Meletius and his journeys in and out of the city.

In John's martyrology, On St. Babylas, and his later homily, On Babylas against Julian and the Pagans, he is careful to stress the location and movement of the bones of the martyr to recreate heterotopic spaces around the Antiochene city limits. ${ }^{10}$ In On St. Babylas, we first learn how Babylas, the bishop of Antioch, was killed.

7. See Shepardson, Controlling Contested Places, 163-203.

8. Shepardson, Controlling Contested Places, 74-78.

9. See Julian, Mis., 361B. Ammianus Marcellinus also notes the fire, which is a surprisingly welldocumented event that has been preserved from a variety of points of view, see Ammianus Marcellinus, Res gest. 22.13.1-2. We will soon see Sozomen's perspective on the events and how they relate back to Meletius of Antioch.

10. John Chrysostom, Bab. Jul. Editions: SC 362, 90-274; CPG 4348; PG 50, 533-72. Translation: Schatkin and Harkins, Saint John Chrysostom. According to Christine Shepardson, the text was written 
An uncommonly virtuous man, he called out a tyrannical emperor for his horrific behavior. At the height of the Decian persecution (250), an unnamed emperor unwisely chose to murder a young royal captive who had been moved to Antioch to be raised in the emperor's household. This violated a number of laws, but the boldest offense was the tyrant's decision to attend church after committing such a heinous act. Babylas, upon learning of the emperor's misdeed, expelled the murderer from the church. The emperor did not take too kindly to this and, in turn, chained the bishop and placed him in prison. ${ }^{11}$ The bishop was eventually killed and buried in a Christian burial plot. At this point in his narrative, John does not say whether this was inside or outside the city. Upon the martyr's request, he was buried with his chains, and both his bones and his chains were considered relics.

Many years later, another figure, Constantius Gallus (Constantine's nephew and then Caesar of the East), transferred these relics from the city of Antiochhere John is careful to say they were in the city-to the neighboring retreat of Daphne. According to John, Gallus did this in an effort to build upon and, in turn, influence the healing properties of the sacred site, as well as quell some of the more debauched behaviors that appeared to plague the Temple of Apollo. ${ }^{12}$ The transfer proved to be more effective than the young Caesar could have hoped for, and the demon that was housed in the Temple of Apollo was immediately silenced. The temple soon fell under disuse and disrepair and was in serious need of restoration by the time Julian rose to power.

Upon the death of Constantius II in November 361, Julian moved to Antioch and began his many efforts to restore and reform Greek traditions and revive the Roman cult practices across the empire (361-363). After his arrival, he heard about the troubles in the local temple at Daphne and sought to discover the source of its problems. He quickly learned of his brother Gallus's decision to move the bones of the martyr and effectively silence the oracle (or demon) in the temple. John then reports that Julian had the bones moved back to the original burial spot. In a particularly revealing moment, John states:

That he [Babylas] inspired these two individuals [Gallus and Julian] with greater fear than the first person [the original tyrant] is clear from this fact. The one seized,

while John was in Antioch, sometime between spring 379 and spring 380; see Shepardson, "Rewriting Julian's Legacy: John Chrysostom's On Bablyas and Libanius' Oration 24," Journal of Late Antiquity 2, no. 1 (2009): 99-115. John Chrysostom, Bab. Editions: CPG 4347; PG 50, 527-34. Translation: J. Leemans, W. Mayer, P. Allen, and B. Dehandschutter, Let Us Die That We May Live: Greek Homilies on Christian Martyrs from Asia Minor, Palestine and Syria c. AD 350-AD 450 (London: Routledge, 2003), 140-48.

11. For a history of imprisonment and the use of chains in late antiquity, see Hillner, Prison, Punishment, and Penance, 163-93.

12. We are led to believe that this was due to the behavior of its founder, Apollo, who infamously pursued the nymph Daphne in an effort to sexually assault her. Before Apollo could catch her, however, she was turned into a tree in an effort to preserve her from the insatiable desires of the pursuing god. John narrates the myth in chapter 67. 
bound, and executed him, but the other only changed his location.... [Julian] should have banished [apoikizein] it to the recesses of the mountains. But no less than Apollo himself, the wretch knew the strength of the blessed one and his relationship with God, and he feared that if he did this he would call forth a thunderbolt or some other disease upon himself (Bab., 91).

The original tyrant was a fool to destroy the bishop of Antioch, but Julian was a greater fool for moving the relics back to the burial plot rather than banishing them from the city. He appropriately feared that banishment would go too far, and we soon learn why. As soon as the martyr was transferred, John remarks, a fire took place at the temple and destroyed the roof, along with the image of Apollo held within it. ${ }^{13}$

The story of the martyr is repeated, although in a truncated version, in John's later homily, given on the feast days of both Ignatius and Babylas. In this reflection, John notes how the relics of Babylas find their final repose not inside the city, but outside the city and across the Orontes River (Bab. 3). It appears that the holy bones were eventually banished, just not under Julian's directive. Here we learn the significance of this final flight. The relics were cared for and attended to by a man who "shared with him the same dignity" (Bab. 10). Although the caretaker goes unnamed, we ought to assume that John is referring to Meletius, who also resided just outside the city limits. As Shepardson stresses, "Equally important for Chrysostom, however, was not just that Meletius and Babylas were both saints, but that Meletius had self-consciously forged a relationship with Babylas while he was still alive, and thus rightfully enjoyed his place next to him in death." ${ }^{14}$ While this is certainly a significant detail, even more important is where these relics were placed. At the end of Meletius's career, he was said to have led a community in a church attached to the martyrium named after Babylas outside of the city. When Meletius died, he found his final resting place in this spot where the martyr was buried. John is careful to stress in his hagiography that Meletius's remains do not stay in Constantinople, where he died, but are moved to the martyrium just outside of Antioch. ${ }^{15}$ And there he remains as Babylas's "fellow-lodger" and "imitator" (Bab., 10).

Meletius's decision to worship and to live outside the city limits was not an impossible detail for John to reconcile. In an earlier hagiography by John, Meletius was said to have carried the city with him into exile-a detail Ps.-Martyrius

13. Soon after this account, John also remarks that God's wrath frequently takes shape in spaces of idolatry. He notes another fire among the rebuilding efforts in Jerusalem when Julian encouraged the Jews to return and rebuild. In that instance, the Jews were also consumed by the flames (Bab. 119-20). John's vitriol for the Jews has been well documented. For an excellent recent survey, see Susanna Drake, Slandering the Jew: Sexuality and Difference in Early Christian Texts (Philadelphia: University of Pennsylvania Press, 2013).

14. Shepardson, Controlling Contested Places, 86.

15. This point is stressed in Shepardson, Controlling Contested Places, 87; and Wendy Mayer, "Antioch and the Intersection between Religious Factionalism, Place and Power," in The Power of Religion in Late Antiquity, ed. A. Cain and N. Lenski (Aldershot, UK: Ashgate, 2009), 361. 
was also careful to emphasize-and it appears that the bones of Babylas followed him (John Chrysostom, Melet. 5). ${ }^{16}$ Like Athanasius does in his heterotopic desert, Meletius recreates a holy site where the he and Babylas find their final rest, no longer confined by those walls that would determine who was or was not a Christian. The heterotopic spaces were free from those constraints.

The exiled bishop, neither firmly anti-Nicene nor explicitly pro-Nicene, embodied an exilic identity that may have paved the way for John in his later reflections. With the bones of Babylas firmly in his control, Meletius took on the authority of the wandering martyr. Both men were remembered as persecuted figures, and neither could stay put. It is only fitting, then, as John would stress, that the exiled bishop was buried alongside the martyr. Yet, as Sozomen will demonstrate, Meletius's legacy remained just outside the city, like his orthodoxy. For this next historian, the powerful memory of the martyr was not enough to preserve the legacy of the city or those fleeing bishops who were associated with them.

\section{HOW TO REMEMBER ORTHODOX FLIGHT: SOZOMEN \\ OF CONSTANTINOPLE'S ECCLESIASTICAL HISTORY}

The fifth-century historian Sozomen of Constantinople wrote his Ecclesiastical History in Constantinople between 440 and $443 .{ }^{17}$ Little is known about him beyond the autobiographical details he provided in his works. Like his predecessors, he begins his history by stating that he will begin where Eusebius of Caesarea left off and covers the history of the Christian Church from 323 to 439. With Nicaea's triumph echoed in Sozomen's work, it is clear why it was dedicated to Theodosius II. What stands out, however, is how Nicaea's legacy is intimately tied to Antioch's history. ${ }^{18}$ Other locations certainly play a role in his narrative. For instance, Alexandria and its dealings with Athanasius shift in and out of focus as the battle for Nicene terminology made its way across the Roman Empire. According to Sozomen, the West was won through the efforts of both Eusebius of Vercelli and Hilary of Poitiers, who aligned themselves with the Athanasian creed. Antioch proved to be a much more difficult case due to the party politics at play once the so-called apostate, Julian, sowed chaos among the Christian citizens of the empire. While exile played out as a larger plot point throughout Sozomen's broader narrative, it was absolutely central to Antiochene and Constantinopolitan efforts to lay claim to a Nicene presence in the Eastern Roman Empire.

16. For a discussion on the significance of this point, see chapter 4 .

17. Sozomen, Eccl. Hist. Edition: CPG 6030; PG 67.V. 14 (1253); G. C. Hansen, Sozomenus Kirchengeschichte, 2nd ed., Griechischen Christlichen Schriftsteller 4 (Berlin: Akademie Verlag, 1995). Translation: NPNF2 2:179-427.

18. For a more detailed exploration of Antioch's history and its role in how various exiles are tied to that space, see chapter 3 . 
Sozomen thus begins his history by telling us the history of Antioch. Due to the Great Persecution, he remarks, Antioch had no bishop. But after the Council of Nicaea, Eustathius was appointed as its first bishop. Important for our interests, Eustathius is also cited as the first bishop to be expelled in the fallout of Nicene debate. His flight introduced the series of controversies directly related to the Antiochene episcopacy, which included Meletius of Antioch's much-troubled appointment. Sozomen's history is a story of Christian flight. If Eustathius's noted support of Athanasius of Alexandria tells us anything, it is that this legacy of flight was tantamount to this pro-Nicene historian's history of orthodoxy.

Sozomen himself was also no stranger to exile. As he states in a rare autobiographical moment, his family also experienced Christian persecution and flight under Julian's rule: "Hence, although not absolutely persecuted by the emperor, the Christians were obliged to flee from city to city and village to village. My grandfather and many of my ancestors were compelled to flee in this manner" (Eccl. Hist. 5.14, emphasis mine). Notably, this lineage follows Sozomen's description of Athanasius's fourth exile. We are reminded that Athanasius, too, was expelled during the so-called apostate's reign. For Sozomen, Athanasius's exilic past provides insight into how a Christian persecution could take place even when no imperial edict had been invoked.

Julian's momentary reprieve of all those who had been exiled under Constantius's rule was not an act of benevolence, but a way to sow discord and chaos across the empire. It also gave the emperor an excuse to further persecute men like Athanasius, who rightfully took back his church upon his return. Yet it was this decision to take back control of Alexandria that Julian cited as the reason to expel him a fourth time. Christian persecution took on many forms in this new era, according to Sozomen. It was a secret war, and the many enemies of the church lurked about in disguise-some even claimed to be defenders of the faith. Yet Sozomen's treatment of Meletius's narrative departs significantly from the treatments of it by Theodoret and John. The significant difference is most clearly seen in his account of the transference of Babylas's bones to Antioch in book 5 .

Sozomen preserves fragments of Julian's oration, which described how the events unfolded, and provides his own creative interpretation. Here the story sounds familiar, with a few notable differences. According to Sozomen, after Constantius appointed Gallus, Julian's brother, to the position of Caesar, the young man took on the zeal of a true Christian. When he moved to Antioch, he took it upon himself to reform the city and the neighboring territory, including Daphne. Its reputation was notorious, and Gallus sought to cleanse the territory by first installing a house of prayer and then transferring the bones of the martyr Babylas to the area. We are familiar with the events that followed. As soon as the bones took up residence there, the demon who lived in the temple ceased to speak. The demon remained silent even after Julian's arrival close to a decade later, due to the martyr's oppressive presence. Julian went to consult the demon to figure out what 
was amiss, but the demon could only admit to the area being filled with dead bodies that silenced the oracle. Julian discerned the cause immediately and had the bones of Babylas removed and returned to the city.

Here Sozomen departs from John's narrative, described above. He states that the bones were moved to that place where they now reside, which meant outside the city. The movement of the relics then transformed into a religious procession that insulted Julian's sensibilities. In Sozomen's version, Julian attempts to punish the Christians for their offensive ritual and arrests several of them, including a young man named Theodore, who is tortured. This proved in vain, because the youth simply sang the same psalm that the crowd sang during their processional and went through the ordeal without any anguish. Rather than make a martyr out of the boy, Julian reluctantly released him, along with his compatriots.

Sozomen then reports on the great fire that took place at Daphne. Both the roof of the temple and the statue of Apollo were destroyed, and credit was ascribed to the departed martyr. In turn, the pagans are said to have blamed the Christians for setting fire to the temple, but no one was found guilty. Sozomen notes many instances when Julian attempted but failed to restore other non-Christian temples outside of Antioch, including the Jewish Temple in Jerusalem. Fire after fire broke out and laid waste to all of his efforts. It seems the relics of the long-dead martyr had inspired more than a few arsonists across the empire. Nevertheless, these relics were preserved beyond the city walls from the start to finish. This slight change in the reception of the story of the martyr Babylas is central to Sozomen's departure from John's glorification of Meletius and the problem of episcopal succession in and around Antioch.

The next two books in Sozomen's history focus more narrowly on the ecclesiastical battles that plagued Antioch and Constantinople. After Julian's death, and after his successor, Jovian (363-364) sought to undo the damage Julian had wreaked, we hear of the Synod of Antioch, where the Nicene Creed was to be confirmed once and for all. Euzoius, the leader the Arian faction in Antioch, went to great lengths to prevent the creed from being confirmed. He sent a representative to Alexandria to conspire with other known Arians to undermine Athanasius's authority. Jovian, not so easily duped, expelled these men and encouraged Athanasius to return. But, as we have come to expect, the life expectancy of Athanasius's imperial supporters was all too short. Jovian died a mere eight months after he had taken up his post, and Valentinian was proclaimed emperor (364-375).

The newly proclaimed emperor was himself a former exile, according to Sozomen. He had been banished to Armenia after offending Julian with his pious behavior (Eccl. Hist. 6.6). He was restored under Jovian and even moved to Nicaea, certainly a confirmation of his Christian faith. Then, after his rise to power, he moved to Constantinople and raised his brother Valens to the position as co-emperor. Valens, however, was not as pious as Valentinian proved to be. Valens had been baptized by the anti-Nicene bishop Eudoxius, who, at this point, was in control of 
Constantinople (360-370). It is for this reason, that ill-fated baptismal link, that Meletius was ultimately expelled. Valens took up residence in Antioch and, upon his arrival, exiled Meletius a second time. (Meletius had already returned from his first exile by this point.) Valens permitted Paulinus to remain, because of his virtuous life, but ordered all those who stayed in the city to either to fall in line with the anti-Nicene bishop Euzoius or risk expulsion as well (Eccl. Hist. 6.7).

In his narration of events, Sozomen then turns to Constantinople, where the pro-Nicenes and followers of Novatian were being persecuted in an identical fashion as their counterparts in Antioch. The consequence of any pro-Nicene claim, of course, was expulsion. Sozomen zeroes in on the Novatian community to emphasize this point: "They were all ultimately expelled from the city; and the churches of the Novatians were closed by order of the emperor. The other party [other Nicene Christians] had no churches to be closed, having been deprived of them during the reign of Constantius" (Eccl. Hist. 6.9). Peter Van Nuffelen has recently drawn attention to this peculiar moment in Sozomen's history. In his view, Sozomen may have been a member of the Novatian community in Constantinople, which is positively represented throughout this work. ${ }^{19}$ At the very least, he is certainly a sympathetic observer. We will return to Van Nuffelen's observations momentarily. For now, it is important to emphasize that Constantinople served as the focal point of Christian orthodoxy during Sozomen's lifetime. It is not without reason that Theodosius II, who represents this victory, is the imperial hero of this narrative and bookends Sozomen's narrative of Nicene triumph. The exiles that link Antioch, Alexandria, Nicaea, and now Constantinople mirror one another and are of key significance for Sozomen.

Books 6 and 7 function as the center point of his narrative and relate what serves as the foundation story of Nicene orthodoxy and Christian flight. Here Sozomen turns to the final exile of Athanasius. He states that one last attempt to undermine the Nicene cause is made by Eudoxius in Constantinople. Curiously, the heretic bishop attempts to persuade Valens to once again expel all those who had been banished by Constantius and returned under Julian. Readers might ponder why he would insist on the expulsion of this group? We learn this was a power move that condemned not just part of Athanasius's career as a fleeing bishop but the entirety of his life in flight. Sozomen remarks, "On account of this order, those who were at the head of the government of Egypt were anxious to deprive Athanasius of his bishopric and expel him from the city; for no light punishment was inserted in the imperial letters" (Eccl. Hist. 6.12). In response, the entire city of Alexandria unites. They implore the governor not to expel Athanasius once again. And here we find a summary of Athanasius's career as an exile from Constantius on:

19. Peter Van Nuffelen, "Episcopal Succession in Constantinople (381-450 C.E.): The Local Dynamics of Power," Journal of Early Christian Studies 18, no. 3 (2010): 425-51. 
The majority of Christians of the city, however, assembled and besought the governor not to banish Athanasius without further consideration of the terms of the imperial letter, which merely specified all bishops who had been banished by Constantius and recalled by Julian; and it was manifest that Athanasius was not of this number, inasmuch as he had been recalled by Constantius and had resumed his bishopric; but Julian, at the very time that all the other bishops had been recalled, persecuted him, and finally Jovian recalled him. The governor was by no means convinced by these arguments; nevertheless, he restrained himself and did not give way to the use of force. The people ran together from every quarter; there was much commotion and perturbation throughout the city; an insurrection was expected; he therefore advised the emperor of the facts and allowed the bishop to remain in the city (Eccl. Hist. 6.12).

Here we have a change in details. Constantius is noted as the emperor who exiles Athanasius a second time and then famously allows Athanasius to return. As we might recall, this return was due to the appeals made by the emperor's younger brother and co-emperor, Constans (who dies soon after Athanasius's return). The reprieve is short. Athanasius flees into exile a third time, and remains in exile until Constantius's death. ${ }^{20}$ According to Sozomen, he was expelled yet again, this time by Julian, because he took back his post and inspired a good portion of the city to follow Christ, which caused Julian to state that, while he had been allowed to return, he had not been permitted to take up his duties. This fourth flight, then, although imperially sanctioned, was fiercely contested by the Alexandrian citizens. Nevertheless, well-practiced in flight by this point, Athanasius secretly departed from the city a final time. Officials soon sought him out and, to their surprise, he was miraculously nowhere to be found. Upon learning of these events, Valens allowed Athanasius to return once again. Sozomen states that this was due to his fear of Valentinian and the general mutiny that the fourth exile might inspire, given Athanasius's popularity. Even the Arian leaders feared the fallout of this exile and did not protest. Sozomen concludes, "They were greatly troubled by the evidences of the virtue and courage of Athanasius, which had been afforded by the events that had transpired during the reign of Constantius" (Eccl. Hist. 6.12). And so Athanasius served as a model that other men of virtue ought to emulate. While others suffered expulsion during this period, Sozomen stresses, Athanasius had already proven too much the hero to take on and therefore preserved Alexandria from any further persecution.

Constantinople would also taste the rewards of Athanasius's success, but not yet. After the death of Eudoxius, another Arian bishop replaced him. But this bishop, Demophilus, as we have learned elsewhere, would not have as strong a hold as his predecessor. Evagrius was then elected as a pro-Nicene rival and ordained by that very first bishop exiled from Antioch after the Nicene council, Eustathius.

20. According to Sozomen, at least for a time during this third exile, Athanasius resides in the city with a famously beautiful (unnamed) virgin; see, Sozomen Eccl. Hist. 5.6. After Constantius's death, he once again appears in the midst of the city ready to take back his position, which Julian initially allows. 
In an effort to bring us full circle, Sozomen states that Eustathius had been recalled by Jovian but decided not to return to Antioch. Instead, he went to support and thus ensure the victory of the small Nicene community in Constantinople. Valens ultimately had to step in and quell the rising theological coup (from Nicomedia, no less), but the damage had been done. Even though Evagrius was banished, along with Eustathius, this event appeared to be the turning point for Sozomen, as all true exiles had proven. Athanasius had won. After a particularly horrific account, in which a number of exiles were placed on a boat that was eventually set on fire, resulting in the merciless death of all the men, we hear of weakening Arian attempts to expand their control with the help of Valens. One by one, the anti-Nicene efforts began to collapse.

Eusebius and Basil of Caesarea, for example, curtail the anti-Nicene efforts in Cappadocia. We heard of these events in Gregory of Nazianzus's account discussed in chapter 2. And like Gregory's report, Sozomen also takes notice of the events that led to a Nicene victory. As we might recall, the emperor Valens's son takes ill and ultimately dies. Sozomen states, “The death of his son was universally attributed to the vengeance of God as punishment of his parents for the machinations that had been carried on against Basil. Valens himself was of this opinion and, after the death of his son, offered no further molestation to the bishop" (Eccl. Hist. 6.16). In true biblical fashion, the death of the children of corrupt emperors (or empresses, as we saw with Eudoxia) appears to be the natural outcome of the enemies of God. ${ }^{21}$

The Nicene position was on the rise and peaked when Gregory of Nazianzus was appointed bishop of Constantinople. Valens was still determined, however, and returned yet again to Antioch, where he expelled all who aligned themselves with Nicaea. He even initiated what Sozomen describes as an imperial persecution, although members of his own heretical party resisted such efforts. And like in Alexandria, the Antiochene citizens proved too strong for the emperor and took the persecution as an opportunity for martyrdom. Not incidentally, Sozomen capitalizes on this moment by announcing the death of Athanasius. Peter, his successor, was arrested, and the Arians once again took hold of Alexandria, with aid from Euzoius, who, after installing Lucius as the Arian bishop in Alexandria, returns to Antioch. Yet this was only a temporary setback. Not even Athanasius's death would determine the outcome of Nicene orthodoxy. Dead or alive, the story of flight proved too strong.

Lucius, in his arrogance, decided to take on the desert. As we saw in chapter 1, the desert had already become a refuge and a stronghold for Athanasius, who had strategically aligned Alexandrian theology with the neighboring monks. Sozomen, not unfamiliar with this alliance, given his frequent references to Antony in

21. We might recall that the firstborn sons of the Exodus account, including the Pharaoh's son, also faced this consequence. See Exodus 11:1-13:16. 
this section, uses the desert to reveal Lucius's tenuous hold on the Nicene presence in and around Alexandria. These men of the desert were the disciples of Antony, a monk who had already reaped the benefits of the desert (and was cloaked in the robes of the Alexandrian bishop). The victory of Nicaea was sure to come, and the armed men and women of the desert knew where their strength came from.

The unquestionable orthodoxy of the monks in the desert further highlights Sozomen's own background as an ascetic sympathizer and a supporter of the Tall Brothers in a later tense and quite different controversy that pit John Chrysostom against Theophilus of Alexandria. We will return to the Origenist controversy momentarily, but for now it is important to note that Sozomen laid the groundwork for a fierce alliance between Alexandria and Antioch. It is this alliance that ultimately placed Meletius of Antioch's legacy in a precarious position.

\section{COMPETING MEMORIES: SOCRATES AND SOZOMEN}

The reception history of Meletius of Antioch in the reflections of both Sozomen and Socrates demonstrate the conflicting history of Christian flight and spatial politics. The pro-Nicene narrative is entirely dependent upon this link. As Wendy Mayer has pointed out, these two ecclesiastical historians had differing opinions when it came to the triangular battle between Antioch, Alexandria, and Constantinople. ${ }^{22}$ All orthodox roads would invariably lead to Constantinople, but the aftermath of the Johanite faction - that is, the reception of John Chrysostom's legacy after his death in exile-reveals for us the battle over the legacy of Christian flight and its complicated relationship with Christian authenticity. Again, we return to Van Nuffelen's observations, which we considered above. He also offers an invaluable analysis of fifth-century party politics as a way to trace how the memory of Christian purity during times of imperial persecution still played a significant role in and around Constantinople in its episcopal succession history. ${ }^{23}$ Both Mayer and Van Nuffelen provide us with the pieces necessary to determine how Meletius of Antioch's life as an exile, death in Constantinople, and eventual interment outside the walls of Antioch ultimately prevented him from inheriting an unquestionable, orthodox Nicene legacy after his death-unlike that of John Chrysostom.

Sozomen-and Socrates before him-have different takes on John Chrysostom's exile and his relationship with Meletius. As we previously explored in chapter 3, Mayer notes that John's election as the bishop of Constantinople came with its own controversies. Chief among them was his ongoing support of the Meletian faction in Antioch after he had taken control of Constantinople. Since Meletius and his successor, Flavian, were in direct opposition to the Alexandrian favorite

22. Mayer, "Antioch and the Intersection," 357-67.

23. See Van Nuffelen, "Episcopal Succession" n. 55 for a full description of his evidence. 
(and Athanasian theological surrogate), Paulinus, Nicene supporters were constantly at odds well before and after John's career. Mayer has remarked:

Indeed in 381 we see a council of western bishops at Aquileia, led by Ambrose of Milan, at which demands were made that a general council be convoked at Alexandria to rule in the case of Antioch in regard to the election of Flavian (in other words, to deny the legitimacy of his election in favor of Paulinus) and also to affirm Maximus, Alexandria's candidate, as the legitimate bishop of Constantinople. ${ }^{24}$

This battle plagued John's episcopacy and eventually resulted in a Johanite faction immediately after his death. Mayer has already convincingly showed how this division was confirmed in John's legacy. But how do heresiology and exilic discourse play a role in the memory-making process of two ecclesiastical historians in the fifth century? The exiles of Meletius and that of John Chrysostom tell us a great deal.

The Origenist controversy was a defining point of contention in how these two men would be remembered. Mayer has pointed to how Epiphanius (ca. 310-403), the bishop of Cyprus_and a wandering bishop in his own right-immediately questioned John Chrysostom's orthodoxy. ${ }^{25}$ This caustic rejection of John would result in more than a few ancient and contemporary rejections of Epiphanius's authority and credibility. ${ }^{26}$ Nevertheless, his suspicion of John is symptomatic of a larger issue at play between Antioch and Constantinople during and soon after Chrysostom's death.

Socrates, as noted above, is much more critical of Meletius's initial election by a non-Nicene party in Antioch. He states, "Now he at first avoided all doctrinal questions, confining his discourses to moral subjects; but subsequently he expounded to his auditors the Nicene Creed, and asserted the doctrine of the homoousion" (Eccl. Hist. 2.44). Socrates argues that Meletius was sent into exile because he promoted the Nicene Creed. Yet, even after a clear Nicene opponent was elected, Euzoius (who, incidentally, was deposed with Arius in Socrates's memory), the initial election of Meletius by a non-Nicene party was still too damning, and his supporters, all of them, would suffer for it. Socrates continues, "Such, however, were attached to Meletius, separated themselves from the Arian congregation, and held their assemblies apart: nevertheless, those who originally embraced the homoousian opinion would not communicate with them, because Meletius had

24. Mayer, "John Chrysostom as Bishop," 458.

25. Ibid., 460-61.

26. Two recent works have shown how Epiphanius's memory has often been cast off and rejected; see Young Richard Kim, Epiphanius of Cyprus: Imagining an Orthodox World (Ann Arbor: University of Michigan Press, 2015); and Andrew Jacobs, Epiphanius of Cyprus: A Cultural Biography of Late Antiquity, Christianity in Late Antiquity Series (Berkeley: University of California Press, 2016). The two have been reviewed together in a forum introduced by Mark DelCogliano, "Epiphanius of Cyprus: Reconsidered," Ancient Jew Review, January 30, 2017, www.ancientjewreview.com/articles/2017/1/12/epiphanius-of-cyprus-reconsidered. Other articles in the forum are linked from DelCogliano's introduction. 
been ordained by the Arians, and his adherents had been baptized by them" (Eccl. Hist. 2.44). This heretical memory is made all the more potent in book 3 of his Ecclesiastical History. Alexandria's ongoing rejection and Meletius's refusal to defer to Paulinus constituted the final breaking point. Meletius did indeed return from exile, but he found that Paulinus's congregants refused to unite with his supporters. So what did he do? He moved his supporters outside the city walls. Yet Socrates would not completely reject Meletius. His memory, although ambivalent, was still tied to John Chrysostom, which differs from Sozomen's assessment.

Sozomen also retains an ambivalent narrative regarding Meletius's episcopacy and his episcopal successors in Antioch (Flavian) and Constantinople (John). In section 7.7, Sozomen argues that the emperor Gratian's edict of toleration resulted in Meletius's return from his Syrian exile in 378. Sozomen reports that he goes unchallenged by Dorotheus, the Arian bishop, and although he is rejected by Rome and Alexandria, Meletius is eventually favored by the newly appointed emperor of the East and defender of Nicene Christianity, Theodosius I (379-383). Paulinus, the favorite of Alexandria and Rome, does not pose enough of a threat to unseat Meletius. And there remains a tripartite episcopacy in Antioch from at least 379 through 381 .

Both Sozomen and Socrates report that Meletius travels to Constantinople, presumably for the great council under the control of Gregory of Nazianzus, and dies there. And as previously stated, after Meletius's death in Constantinople, he was succeeded by Flavian, which caused further controversy in Antioch, as we now know. J. N. D. Kelly goes so far as to claim that Gregory of Nazianzus was responsible for this controversial appointment. ${ }^{27}$

According to Sozomen, there was a gentleman's agreement that, upon Meletius's death, the episcopacy would transfer directly to Paulinus, who still remained in control of his church and congregation. As do most gentleman's agreements, however, the attempt failed. The Antiochene position passed to Flavian, who was supported by John Chrysostom.

Socrates, on the other hand, places blame on Meletius and his decision to maintain a factional group in (or just outside) Antioch even after Paulinus's appointment. After Meletius's death, a firmly rooted community continued to divide the Nicene Christians. This story of division is replicated in John's life, exile, and death. Mayer points out that Socrates was a harsh critic of John, unlike his other biographers, Palladius and Ps.-Martyrius. She states, "Socrates' primary concern, in devoting an entire book to the events associated with John, is to document the most recent and most devastating schism within the church and to frame the individual at the centre of the schism, John, as a schismatic." ${ }^{28}$ Meletius served as an important and dangerous model for John, at least according to Socrates.

27. Kelly, Golden Mouth, 38; and Sozomen, Eccl. Hist. 7.3.

28. Mayer, "Making of a Saint," 40. 
Van Nuffelen strengthens this connection all the more in his recent assessment of episcopal succession in and around Constantinople, in which the ecclesiastical historians play a decisive role. ${ }^{29}$ Party politics are at play in Antioch, where antiNicene and pro-Nicene episcopal battles are waged and then replicated in Constantinople's history. What Van Nuffelen notes, however, is the way the Novatian community in Constantinople adds an additional layer to Constantinople's struggle over pro-Nicene orthodoxy. Sozomen, for Van Nuffelen, is at the heart of this connection, but I want to draw our attention to how the Novatians, as the inheritors of a presumably purer form of Christianity-meaning a history of confessors who did not flee-is preserved in a Constantinopolitan context. This link abuts a pro-Nicene community that finds itself at odds and yet in alliance with the group.

By the fourth century, the established community of Novatians in Constantinople had its own flavor and political alliances. As a reminder, this community harkens back to an earlier period, in which the heroes of Christianity were the men and women who stood up to the tortures of the empire during the Decian persecution (250-251), rather than the ones who fled..$^{30}$ Their refusal to admit the lapsed, the ones who committed atrocities such as flight during the persecution, often put them at odds with other Christian communities in Constantinople. The pro-Nicene faction in Constantinople was thus typified in the person and legacy of Athanasius of Alexandria and later aligned with John Chrysostom and his career in flight. This legacy posed a significant problem for the Novatian community. As Van Nuffelen has remarked: "The closer the Novations moved to the Nicenes, the higher the risk of succumbing to the pressure of assimilation exercised by the state." ${ }^{11}$ This contentious relationship was further exaggerated by their own experience of flight through frequent expulsions from the city and their on-again offagain status as heretics. ${ }^{32}$ Socrates and Sozomen would nevertheless refer to this particular community as an important ally at different stages in the battle between pro-Nicene and anti-Nicene Christians. Novatians would align themselves with bishops and even pass as pro-Nicenes when bishops believed this alliance would work to their advantage.

The one exception appeared to be over the election of the bishop Sabbatius (Socrates, Eccl. Hist. 5.21.6-19, 7.5). Socrates, either a Novatian himself or a sympathizer, stated that this troublesome character was a converted Jew-a suspicious beginning for Socrates-with high ambitions to become the bishop of Constantinople..$^{33}$ After his brief attempt at a coup to take the episcopacy, Sabbatius was

29. Van Nuffelen, "Episcopal Succession," 425-51.

30. Martin Wallraff, "Geschichte des Novatianismus seit dem vierten Jahrhundert im Osten," Zeitschrift für Antikes Christentum 1 (1997): 251-79.

31. Van Nuffelen, "Episcopal Succession," 431.

32. Caroline Humfress, Orthodoxy and the Courts (Oxford: Oxford University Press, 2007), 217-42.

33. For Socrates, formerly being a Jew meant that Sabbatius was therefore not a true Christian. Socrates even stated that Sabbatius had led many astray (Eccl. Hist. 7.5). 
exiled. He died on the island of Rhodes (a rare reference to an island exile), where his body continued to be adored by his followers and to lead Christians astray. Finally, Socrates states that the rival bishop Atticus had his body removed and hidden. "He caused the body to be disinterred at night and deposited in a private sepulcher; and those who had formerly paid their adorations at that place, on finding his tomb had been opened, ceased honoring that tomb thenceforth" (Eccl. Hist. 6.25). This exiled bishop would not posthumously return to Constantinople. He remained outside both place and memory of orthodoxy altogether. Meletius of Antioch's body, however, would take a different journey.

To briefly summarize, both Mayer and Van Nuffelen note the significance of the Johanite schism preserved in the works of both Socrates and Sozomen, and they place special emphasis on John's dealings in Constantinople. Mayer even highlights Socrates's strong anti-Johanite stance, which finds its links to the Meletian schism in Antioch. John is not Socrates's hero, and it is therefore unsurprising that his predecessor also receives harsh treatment in his narrative. Sozomen, on the other hand, with whom John's other biographers appear to be in alignment, was much more sympathetic to John for different reasons, according to both Mayer and Van Nuffelen. But Sozomen did not extend the same sympathy to Meletius. While Van Nuffelen has focused primarily on John's legacy and its ties to the Origenist controversy, Mayer's call to take an Antiochene point of view draws us back to this conflicted history of flight. ${ }^{34}$

As we have seen, John's ties to Meletius are more than a simple initiation into Christianity through baptism. Meletius serves as a model for John and his experiences of Christian flight, as we saw in his hagiographical texts in chapter 3. Their twin experiences of exile, which I have highlighted above, continued to be a source of contention for later historians such as Socrates and Sozomen. Meletius's return to Antioch is only ever a peripheral one. Socrates writes:

\begin{abstract}
About this period, [Meletius], bishop of Antioch, fell sick and died. . . . The body of the deceased bishop was by his friends conveyed to Antioch, where those who had identified themselves with his interests again refused subjection to Paulinus, but caused Flavian to be substituted in the place of [Meletius], and the people began to quarrel anew. Thus again the Antiochian church was divided into rival factions, not grounded on any difference of faith, but simply on a preference of bishops. (Eccl. Hist. 5.9)
\end{abstract}

Socrates states that Meletius's body could not stay in Constantinople and that it was returned to Antioch. This transference continued to harm the community rather than promote reconciliation. Not all would remember the movement of Meletius's body in the same way, however. Sozomen preserves this account instead:

34. Van Nuffelen, "Palladius and Johannite Schism," 2-3; and Mayer, "John Chrysostom as Bishop," 455. 
The remains of Meletius were at the same time conveyed to Antioch, and deposited near the tomb of Babylas the martyr. It is said that through every public way, by the command of the emperor, the relics were received within the walls in every city, contrary to Roman custom, and were honored with singing of psalms antiphonally in such places, until they were transferred to Antioch. (Eccl. Hist. 7.10)

While it is clear that Meletius could not stay buried in Constantinople, at least in this latter case the bones of the martyr were enough to preserve his orthodox memory, and also the orthodox memory of John, who would meet an equally questionable end. Meletius still remained on the outside, and it is clear why that may be, as both pro-Nicene historians have continued to stress.

Meletius's legacy as an Arian also influenced John's legacy as an Origenist or, at the very least, as a known colluder with heretics. Both men are questionable at best. While Sozomen was happy to initiate John in the Nicene vision and treat Meletius in a sympathetic manner on the assumption that Babylas would take care of him, Socrates took a more dismissive tone, but he also had to tread carefully. Ultimately, for the pro-Nicene historians, Meletius would remain just outside the city walls and also at the boundaries of Christian memory.

\section{CONCLUSION}

As we have seen, exilic discourse undermined the orthodox project as much as it supported it. Meletius of Antioch's history as an exile was also marred by his association with the anti-Nicene party in Antioch. But, like Tertullian of Carthage, with whom this book began, his memory was not so easily condemned. Instead, he rests uncomfortably just outside of orthodoxy. Meletius's failure was tied directly to his displacement. He never fully made it back into the Antiochene community but always resided just beyond its walls, even in death. It was his connection to John Chrysostom that served to mitigate some of his earlier misguided beliefs, and his association with the martyr Babylas that ultimately preserved his legacy.

Tertullian famously said that the blood of the martyrs is the seed of the church. If you happen to be buried near these seeds, you might take part in their efficacious power. Yet Meletius continues to hold a precarious position in pro-Nicene Christian memory. Due to his dubious election by an anti-Nicene majority in and around Antioch, he is unable to return fully to the city as a triumphant exile. Even if his biographers refer to him as a diplomatic Christian who really subscribed to Nicene Christianity, his earlier association would prove too powerful. Meletius would continue to be relegated to those spaces just beyond the borders of orthodoxy. 


\section{Epilogue}

Frequently identified as a metaphor for the postmodern condition, exile immediately evokes the cultural identity of otherness. ${ }^{1}$ Edward Said captures the significance of this by pointing to the massive shifts in our understanding of the exilic experience. ${ }^{2}$ Given that we are living in the quintessential age of exile, he surmised, it is unsurprising that the topic has been a principal focus in the field of literary studies. Michael Seidel also notes, "Exile is a compelling subject and a propelling action; it names a figure and establishes a narrative." 3 The theme of exile crosses narrative boundaries and elicits all the horrors and the pleasures of displacement. ${ }^{4}$ It can carry both religious and aesthetic significance. ${ }^{5}$ It can also

1. A wonderful example of an embodied exile is captured in Eli Clare, Exile and Pride: Disability, Queerness and Liberation (Cambridge, MA: South End Press, 1999), who explores how her experience as a queer, disabled, and gendered being put her body into exile from an early age. She critically examines her own life experiences, as well as those of others, to show how the othered body is in a constant state of displacement.

2. Edward Said, Reflections on Exile and Other Essays (Cambridge, MA: Harvard University Press, 2000), 174 .

3. Michael Seidel, Exile and the Narrative Imagination (New Haven, CT: Yale University Press, 1986), 1.

4. Dante's famous reflections in the Inferno poetically detail the vast imaginative possibilities of exilic discourse. Not only does he comment on his own exilic existence, but he also draws on the reflections of the most famous exiles in literary history. For Dante's use of Ovid, see D. M. Robatha, "Ovid in the Middle Ages," in Ovid, ed. J. W. Binns (London: Routledge and Kegan Paul, 1973), 191-209; J. L. Smarr, "Poetics of Love and Exile," in Dante and Ovid: Essays in Intertextuality, ed. by M. U. Sowell, Medieval and Renaissance Texts and Studies 82 (Binghamton: State University of New York at Binghamton, 1991), 139-51.

5. Boethius is a particularly notable exile whose influences on Dante and Chaucer ushered the consolatory tradition into the Western world. See Claassen, Displaced Persons. 
serve as a philosophical reflection or poetic expression of being. Patrick McHugh argues that critiques of the Enlightenment offered by Martin Heidegger and Theodor Adorno were crucially illustrated by the theme of alienation. Heidegger pondered the possibilities and mysterious effects of what Adorno conceived in rigorously negative terms as a transcendent resting place for thought, its origin and telos, its home. Heidegger's thought was like a crusade toward a homeland, while Adorno's thought remained in the melancholic truth of exile. ${ }^{6}$ As these writers demonstrate, the theme of exile has innumerable generative possibilities that capture both the narrative and critical imagination.

These theorists also argue that the condition of exile provides the author with a unique perspective. Said, speaking on the good of exile, states, "Most people are principally aware of one culture, one setting, one home; exiles are aware of at least two, and this plurality of vision gives rise to an awareness of simultaneous dimensions, an awareness that-to borrow a phrase from music-is contrapuntal." 7 In short, the condition of exile appears to provide a privileged vantage point. Too often, though, this vantage point has been used to promote certain claims to objectivity, particularly when the condition of exile is infused with religious authority. Consequently, exile is given a position that stands outside the realm of critique if it is left unproblematized. The person in exile, due to his or her experience, is frequently seen as an objective observer. In turn, the exile is even elevated to a position of unquestioned authority. It is as if the very experience of displacement authorizes his or her voice.

Carine M. Mardorossian has recently taken stock of a paradigmatic shift from exile to migrant literature as a response to such claims. She notes that postcolonial writers, in particular, have abandoned the term exile in favor of migrant as a way to draw attention to the problems that the identity of exile continues to carry with it:

It used to be-and too often still is-the case that the mere mention of a writer's condition of exile was sufficient to imply certain foundational premises about his or her work. Exiled writers, for instance, are often seen as better equipped to provide an "objective" view of the two worlds they are straddling by virtue of their alienation. They are ascribed the status of neutral observers, a detachment on which-according to the high modernist tradition that still dictates the discourse of exile-their literary authority is based. ${ }^{8}$

Rather than preserve this position of neutrality, the more open-ended term migrant seeks to emphasize movement, rootlessness, and the mixing of cultures,

6. Patrick McHugh, "Ecstasy and Exile: Cultural Theory between Heidegger and Adorno," Cultural Critique 25 (1993): 121-52. Cf. Seidel, Exile, 123.

7. Said, Reflections, 185 .

8. Carine M. Mardorossian, "From Literature of Exile to Migrant Literature," Modern Language Studies 32.2 (2002): 16 . 
races, and languages. ${ }^{9}$ Theoretically, then, a person in exile is no longer immune from social commentaries and discourses but is thoroughly exposed to these new cultural environments. The displacement of migrants promotes an ambivalence associated with old and new locations and involves a distinct shift away from being to becoming.

The focus on migrant rather than exilic literature in a postmodern context constitutes a political project that attempts to disrupt preset binaries that privilege the status of the in-between. Arguments like these, which hinge on debates over terminology (migrant versus exile), point to a larger problem: what does it mean to claim a displaced identity and its potential to destabilize cultural identities? As Mardorossian appropriately notes, the identity of the migrant helps to dispel modern conceptions of exile as a mediator between an alienating "here" and the romanticized "there" of the homeland. This serves as a necessary corrective once we begin to undermine the powerful cultural identity of the exile that too often blinds the way we see out-of-place bodies.

In this book, I have demonstrated that a similar critical approach is necessary in premodern texts as well. Too often, the term exile bolsters its claimant to an objective position with significant political as well as theological consequences. As we have seen, the path of a bishop in flight is a difficult one to follow. The twelfthcentury mosaic, "The Temptations of Christ," from the Basilica di San Marco in Venice, which serves as the book cover, depicts three images of a winged devil tempting Christ in the desert. ${ }^{10}$ The scenes are ornamented with embossed gold mosaics highlighting where the divinity and the desert landscape meet. It is the space Jesus has fled to before he returns to Jerusalem, ready to take on the final phase of his short ministry. This book seeks to trouble our ability to discern who is or who is not the model of Christian flight. And who is and who is not the devil banished in the lower right corner of the image. Is the bishop a Christ-like figure temporarily fleeing and preparing for his return? Or is he instead the tempter in disguise, marked by his telltale wings of cowardice and false claims to authority? The answer is not so simple. Explored here, we have found that the orthodox bishop is often shaped in the minds and memories of the pro-Nicene authors. Yet, as the mosaic reveals, all that glitters is not gold, at least not to the discerning eye.

As I have shown, Athanasius of Alexandria's identity as an exile was tied to his promotion as both a persecuted Christian and a purveyor of Christian truth. But this unquestioned identity was, and remains, dependent upon a logic of alienation

9. Ibid., 17 .

10. This mosaic is one among many golden images throughout the impressive space. For a description of all the images and, more specifically, the inscriptions found throughout San Marco, see, Rudolph M. Kloos, “The Paleography of the Inscriptions of San Marco" in The Mosaics of San Marco in Venice: The Eleventh and Twelfth Centuries, vol. 1, edited by Otto Demus, 295-385 (Chicago: University of Chicago Press, 1984). 
and persecution that demonizes others as it simultaneously reinforces the claims of the outsider. Like the romanticized exilic literature and postmodern condition of exile, these early Christian narratives exploit the realities of movement and displacement to identify the villains as well as the heroes. This process becomes all the more complicated when the very terms of Christian orthodoxy are defined by the experiences of some episcopal exiles and not others.

As the countercases discussed in the final two chapters have demonstrated, orthodox subjectivity, viewed through the lens of exilic self-fashioning, creates an unstable space. When the bishop was firmly seated on his episcopal throne, his political vulnerability was heavily masked by his position of power. But when the bishop was physically removed from that locus of power, he had to turn to rhetorically inventive strategies to defend his flight. Yet Christian flight and how it became infused with the experience of clerical exile occupied a complicated and contested position within Christian memory. As we examine later writers who looked back at an earlier period, it becomes all the clearer why someone critical of flight during times of persecution-someone such as Tertullian of Carthagecould easily be doubted as an authentic Christian. His criticisms of men in flight proved too powerful, so that his credibility frequently was-and continues to beundermined (was he or wasn't he a Montanist?). Cyprian, too, in his most defensive moments regarding clerical flight, would come under intense scrutiny-at least until he finally died as a martyr.

A consistent theme throughout this book has been that the stories of Christian martyrdom continued to threaten and undermine the seemingly cowardly flights of bishops. But once the imperial legacy of persecution worked to the advantages to the pro-Nicene cause, bishops in flight looked for new interpretative meanings to justify their removal and defend their orthodoxy, even when the terms and locations of orthodoxy had yet to be determined.

I have argued that exile was a new discursive mode deployed by heresiologists and late ancient historiographers in a post-Constantinian context. In this new political environment, bishops fused the language of persecution with classical motifs of exile to legitimize their removal from their episcopal sees and to redefine the terms of Christian flight. The right to survive over and against the privilege to die for one's faith must and did shift from earlier interpretations. It was not enough to stand as a pillar of faith; in this new era, the bishop must live. Exilic discourse provides the historian with a particular angle from which to examine the complicated processes involved in the invention of Christianity in its various manifestations, pro-Nicene and anti-Nicene alike.

In addition to this new discursive mode, I have also shown how the theory of space and place helps us to read displacement. ${ }^{11}$ As Juliette Day, Raimo Hakola,

11. Equally important for this study is how theory works to the advantage of the historian of late antiquity. Here I take seriously the observations made by Clark, who notes that late ancient historians 
Maijastina Kahlos, and Ulla Tervahauta aptly surmise, "Places and spaces are not approached as neutral categories but as key factors in how individuals and groups construct their identities." ${ }^{12}$ As I have frequently noted, the story of Athanasius's desert askesis became a powerfully transient tale. It was read and reread in several texts and spaces as Athanasius's fame, and his version of Christian orthodoxy, spread to cities across the Roman Empire and became central to the Nicene legacy in Constantinople.

Those bishops who were exiled but did not live on as exilic heroes also tell us a great deal about how spaces were infused with theological significance. Like their so-called orthodox counterparts, both Eusebius of Nicomedia and Meletius of Antioch found themselves in exile. While one returned a roaring success and even went on to become the uncontested bishop of Constantinople, the other was saved only by the biographical efforts that placed his death in that same holy city. Yet, through the memory-making process, particular spaces were either condemned or praised, as were the men associated with them. Eusebius and Meletius do not live on as stalwarts of Christian orthodoxy precisely because of the coded cities from which they were exiled. The pro-Nicene narrative of Christian triumph was therefore reliant on the privileged position of a few choice outsiders. Athanasius of Alexandria remained the model of Christian flight. And those who also fled after him had to tread carefully, or they too would find themselves just outside the spaces and places of orthodoxy.

\footnotetext{
"do not possess the type of documents on which social historians of modernity work, but high literary/ philosophical texts that lend themselves well to theoretical analysis" (Clark, History Theory Text, 159). As Esteel remarks, "modernity was infatuated with questions concerning time and history whereas the post-modern obsession appears to be with questions pertaining to space and to geography" (Esteel, "Nonplaces," 117-39). Esteel maps the so-called spatial turn in French theory through a critical lens of nonplace first espoused by Marc Augé.

12. Juliette Day, Raimo Hakola, Maijastina Kahlos, and Ulla Tervahauta, introduction to Spaces in Late Antiquity-Cultural, Theological and Archaeological Perspectives (New York: Routledge, 2016), 2.
} 



\section{B I B L I O G R A P H Y}

Africa, T. "Worms and the Death of Kings." Classical Antiquity 1, no. 1 (1982): 1-17.

Alberigo, Giuseppe et al., eds. Conciliorum Oecumenicorum Generaliumque Decreta. Editio critica. Volume 1: The Oecumenical Councils from Nicaea I to Nicaea II (325-787). Corpus Christianorum. Turnhout: Brepols, 2006.

Amidon, Philip R. Philostorgius: Church History. Atlanta, GA: Society of Biblical Literature, 2007.

Anatolios, Khaled. Athanasius. New York: Routledge, 2004.

. Athanasius: The Coherence of His Thought. New York: Routledge, 1998.

Anderson, Sonja. "Discerning the Body in Cyprian's De Lapsis." Paper presented at the North American Patristics Conference, Chicago, IL, May 27, 2017.

Andrade, Nathaniel. "The Processions of John Chrysostom and the Contested Spaces of Constantinople." Journal of Early Christian Studies 18, no. 2 (2010): 161-89.

Andrews, Jacob. Remains of the Jews: The Holy Land and the Christian Empire in Late Antiquity. Stanford, CA: Stanford University Press, 2004.

Antiochenus, Martyrius. Oratio funebris in laudem sancti Iohannis Chrysostomi: epitaffio attribuito a Martirio di Antiochia (BHG 871, CPG 6517). Spoleto: Fondazione Centro italiano di studi sull'Alto Medioevo, 2007.

Arnold, Duane W. H. The Early Episcopal Career of Athanasius of Alexandria. Christianity and Judaism in Antiquity 6. South Bend, IN: University of Notre Dame Press, 1991.

Athanasius, Jerome, Sulpicius Severus, and Gregory the Great. Early Christian Lives. Translated by Carolinne White. London: Penguin Classics, 1998.

Attridge, Harold W., and Gōhei Hata. Eusebius, Christianity, and Judaism. Detroit, MI: Wayne State University Press, 1992.

Ayres, Lewis. Nicaea and Its Legacy: An Approach to Fourth-Century Trinitarian Theology. Oxford: Oxford University Press, 2004.

Bagnall, Roger S. Egypt in Late Antiquity. Princeton, NJ: Princeton University Press, 1996. Bakhtin, M. M. Rabelais and His World. Bloomington: Indiana University Press, 1984. 
Barnes, Michel R., and Daniel H. Williams. Arianism after Arius: Essays on the Development of the Fourth Century Trinitarian Conflicts. Edinburgh: T \& T Clark, 1993.

Barnes, T. D. Athanasius and Constantius: Theology and Politics in the Constantinian Empire. Cambridge, MA: Harvard University Press, 1993.

- "The Career of Athanasius." In Second Century, Tertullian to Nicaea in the West, Clement of Alexandria and Origen, Athanasius, edited by Ann Livingstone, 390-401. Studia Patristica 21. Leuven: Peeters, 1989.

- Constantine and Eusebius. Cambridge, MA: Harvard University Press, 1981.

—. "The Funerary Speech for John Chrysostom (BHG3 871 = CPG 6517)." Studia Patristica 37 (2001): 328-45.

—. "Hilary of Poitiers on His Exile." Vigiliae Christianae 46, no. 2 (1992): 129-40.

—. "Valentinian, Auxentius and Ambrose." Historia 51, no. 2 (2002): 227-37.

Barnes, T. D., and George Bevan. The Funerary Speech for John Chrysostom. Translated Texts for Historians 6o. Liverpool: Liverpool University Press, 2013.

Barry, Jennifer. "Diagnosing Orthodoxy: Ps.-Martyrius's Funerary Speech for John Chrysostom." Journal of Early Christian Studies 24, no. 3 (2016): 395-418.

- "Heroic Bishops: Hilary of Poitiers's Exilic Discourse." Vigiliae Christianae 7o, no. 2 (2016): 155-74.

- "Receptions of Exile: Athanasius of Alexandria's Legacy." In Hillner, Ulrich, and Engberg, Late Antique Clerics in Exile, 251-62.

Barthes, Roland. Elements of Semiology. Paris: Macmillan, 1977.

—. S/Z. Translated by Richard Miller. New York: Editions du Seuil, 1970.

Bauer, Walter. Orthodoxy and Heresy in Earliest Christianity. Mifflintown: Sigler Press, 2006. Bauman, Richard. Crime and Punishment in Ancient Rome. New York: Routledge, 1996.

Becquette, John. Rhetoric in the Monastic Tradition. New York: Lang, 2012.

—_ "Sulpicius Severus's Life of Saint Martin: The Saint and His Biographer as Agents of Cultural Transformation." Logos: A Journal of Thought and Culture 13, no. 2 (2010): 56-78.

Berger, Albrecht. "Herakles and the Hippodrome of Constantinople." In Hippodrom/ Atmeydani: İstanbul'un Tarih Sahnesi, edited by Brigitte Pitarakis, 194-205. Istanbul: Pera Müzesi, 2010.

—. "Streets and Public Places in Constantinople." Dumbarton Oaks Papers 54 (2000): $161-72$.

Berzon, Todd. Classifying Christians: Ethnography, Heresiology, and the Limits of Knowledge in Late Antiquity. Berkeley: University of California Press, 2016.

Bevan, David. Literature and Exile. Amsterdam: Rodopi, 1990.

Bidez, Joseph. Philostorgius, Kirchengeschichte: mit dem Leben des Lucian von Antiochien und den Fragmenten eines arianischen Historiographen. Berlin: Akademie, 1913.

Bond, Sarah. Taboo and Trade: Sordid Professions in the Ancient Mediterranean. Ann Arbor: University of Michigan Press, 2016.

Borchardt, C. F. A. Hilary of Poitiers' Role in the Arian Struggle. Kerkhistorische studiën behorende bij het Nederlands Archief voor Kerkgeschiedenis deel 12. The Hague: Martinus Nijhoff, 1966.

—_ "Sulpicius Severus' Dependency on Hilary of Poitiers in His Chronica." Acta Patristica et Byzantina 5 (1994): 12-27.

Boyarin, Daniel, and Virginia Burrus. "Hybridity as Subversion of Orthodoxy? Jews and Christians in Late Antiquity." Social Compass 52 (2005): 431-41. 
Brakke, David. Athanasius and Asceticism. Baltimore, MD: John Hopkins University Press, 1998.

- Demons and the Making of the Monk: Spiritual Combat in Early Christianity. Cambridge, MA: Harvard University Press, 2006.

Brennecke, Hanns Christof. Hilarius von Poitiers und die Bischofsopposition gegen Konstantius II. Untersuchungen zur dritten Phase des arianischen Streites (337-361). PTS 26. Berlin: de Gruyter, 1984.

Brennecke, Hanns Christof, Uta Heilsand, and Annette Stockhausen (eds.). Apologia ad Constantium. Lieferung 8. Berlin: de Gruyter, 2006.

Brito-Martinis, Manuela. "The Concept of Peregrinatio in Saint Augustine and Its Influences." In Napran and van Houts, Exile in the Middle Ages, 83-94.

Brown, Peter. The Body and Society: Men, Women, and Sexual Renunciation in Early Christianity. New York: Columbia University Press, 1988.

- "The Rise and Function of the Holy Man in Late Antiquity, 1971-1997." Journal of Early Christian Studies 6, no. 3 (1998): 353-76. doi:10.1353/earl.1998.0041.

Buell, Denise Kimber. Why This New Race: Ethnic Reasoning in Early Christianity. New York: Columbia University Press, 2005.

Burns, Paul C. The Christology in Hilary of Poitiers' “Commentary on Matthew." Rome: Augustinian Patristic Institute, 1981.

. "Hilary of Poitiers' Road to Beziers: Politics or Religion?" Journal of Early Christian Studies 2, no. 3 (1994): 273-89.

—. "The Writings of Hilary of Poitiers in Medieval Britain from c. 700 to c. 1330." In The Writings of Hilary of Poitiers in Medieval Britain from c. 700 to c. 1330, 201-16. Ottawa: University of Ottawa Press, 1999.

Burrus, Virginia. Begotten, Not Made: Conceiving Manhood in Late Antiquity. Stanford, CA: Stanford University Press, 2000.

. "Equipped for Victory': Ambrose and the Gendering of Orthodoxy." Journal of Early Christian Studies 4, no. 4 (1996): 461-75.

—. "The Heretical Woman as Symbol." Harvard Theological Review 84, no. 3 (1991): 229-48.

- The Making of a Heretic: Gender, Authority, and the Priscillianist Controversy. Berkeley: University of California Press, 1995.

- Saving Shame: Martyrs, Saints, and Their Abject Subjects. Philadelphia: University of Pennsylvania Press, 2008.

- The Sex Lives of Saints: An Erotics of Ancient Hagiography. Philadelphia: University of Pennsylvania Press, 2004.

Butler, Edward Cuthbert. The Lausiac History of Palladius. Cambridge: Cambridge University Press, 1898.

Cameron, Averil. Christianity and the Rhetoric of Empire: The Development of Christian Discourse. Sather Lectures 55. Berkeley: University of California Press, 1991.

. "How to Read Heresiology." In Miller and Martin, Cultural Turn, 193-212.

- "Jews and Heretics-A Category Error." In The Ways That Never Parted: Jews and Christians in Late Antiquity and the Early Middle Ages, edited by Adam Becker and Annette Yoshiko Reed, 345-6o. Tübingen: Mohr Siebeck, 2003.

Cameron, Averil, and Stuart George Hall. Eusebius: Life of Constantine. Clarendon Ancient History Series. Oxford: Clarendon, 1999. 
Caner, Daniel. Wandering, Begging Monks: Spiritual Authority in Late Antiquity. Berkeley: University of California Press, 2002.

Canitz, A. E., and Gernot R. Wieland, eds. From Arabye to Engelond. Ottawa: University of Ottawa Press, 1999.

Canivet, P. Le monachisme Syrian salon Théodoret de Cyr. ThH 42. Paris: Beauchesne, 1977.

Castelli, Elizabeth. Martyrdom and Memory: Early Christian Culture Making. New York: Columbia University Press, 2004.

—. "Religious Identity through the Prism of Spectacle in Early Christianity." Paper presented at the Symposium on Identity in Late Antiquity. Duke University. February 20, 2009.

Chadwick, Henry. "Hilarius von Poitiers," in Die Religion in Geschichte und Gegenwart, ed. Kurt Galling and Wilfrid Werbeck (Tübingen: Mohr, 1959), 317.

Claassen, Jo-Marie. Displaced Persons: The Literature of Exile from Cicero to Boethius. Madison: University of Wisconsin Press, 1999.

. Ovid Revisited: The Poet in Exile. London: Duckworth, 2008.

Clare, Eli. Exile and Pride: Disability, Queerness and Liberation. Cambridge, MA: South End Press, 1999.

Clark, Elizabeth A. History, Theory, Text: Historians and the Linguistic Turn. Cambridge, MA: Harvard University Press, 2004.

- Jerome, Chrysostom, and Friends: Essays and Translations. Lewiston, NY: Mellen, 1982. . "John Chrysostom and the 'Subintroductae." Church History 46, no. 2 (1977): 171-85. "The Lady Vanishes: Dilemmas of a Feminist Historian after the 'Linguistic Turn." Church History 7, no. o1 (July 28, 2009): 1.

- The Origenist Controversy: The Cultural Construction of an Early Christian Debate. Princeton, NJ: Princeton University Press, 1992.

Cobb, L. Stephanie. "Polycarp's Cup: Imitatio in the Martyrdom of Polycarp" Journal of Religious History 38, no. 2 (2014): 224-40.

Cohen, Sarah. "Cicero's Roman Exile." In Gaertner, Writing Exile, 109-28.

Conant, Jonathan. Staying Roman: Conquest and Identity in Africa and the Mediterranean, 439-700. Cambridge: Cambridge University Press, 2012.

Corbett, John. "Changing Perceptions in Late Antiquity: Martin of Tours." Toronto Journal of Theology 3, no. 2 (1987): 236-51.

Creed, J. L. (ed. and trans.). Lactantius, De Mortibus Persecutorum. Oxford Early Christian Texts. Oxford: Clarendon, 1984.

Cresswell, Tim. In Place/Out of Place: Geography, Ideology, and Transgression. Minneapolis: University of Minnesota Press, 1996.

- Place: A Short Introduction. Malden, MA: Blackwell, 2004.

Cribiore, R. The School of Libanius in Late Antique Antioch. Princeton, NJ: Princeton University Press, 2007.

Crislip, Andrew. Thorn in the Flesh: Illness and Sanctity in Late Ancient Christianity. Philadelphia: University of Pennsylvania Press, 2013.

Croke, Brian. "Reinventing Constantinople: Theodosius I's Imprint on the Imperial City." In From the Tetrarchs to the Theodosians: Later Roman History and Culture, 284-450, edited by Scott McGill, Cristiana Sogno, and Edward Watts, 241-64. Yale Classical Studies 34. Cambridge: Cambridge University Press, 2010. 
Culbert, John. Paralyses: Literature, Travel, and Ethnography in French Modernity. Lincoln: University of Nebraska Press, 2010.

Daley, Brian. "The Enigma of Meletius of Antioch." In Tradition and the Rule of Faith in the Early Church: Essays in Honor of Joseph T. Lienhard, S.J., edited by Ronnie J. Rombs and Alexander Y. Hwang, 128-52. Washington, DC: Catholic University of America Press, 2010.

Day, Juliette, Raimo Hakola, Maijastina Kahlos, and Ulla Tervahauta, eds. Spaces in Late Antiquity-Cultural, Theological and Archaeological Perspectives. New York: Routledge, 2016.

DelCogliano, Mark. "Epiphanius of Cyprus: Reconsidered." Ancient Jew Review. January 30, 2017. http://www.ancientjewreview.com/articles/2017/1/12/epiphanius-of-cyprusreconsidered.

—. "Tradition and Polemic in Basil of Caesarea's Homily on the Theophany." Vigiliae Christianae 66 (2012): 30-55.

Delmaire, Roland. "Les «lettres d'exil» de Jean Chrysostome. Études de chronologie et de prosopographie." Recherches Augustiniennes 25 (1991): 72-180.

Doblhofer, Ernst. Exil und Emigration: Zum Erlebnis der Heimatferne in der römischen Literatur. Darmstadt: Wissenschaftliche Buchgesellschaft, 1987.

Doignon, Jean. Hilaire de Poitiers avant l'exil: recherches sur la naissance, l'enseignement et lépreuve d'une foi épiscopale en Gaule au milieu du IVe siècle. Paris: Études augustiniennes, 1971.

Douglas, Mary. Purity and Danger: An Analysis of Concepts of Pollution and Taboo. New York: Praeger, 1966.

Dragas, George Dion. Saint Athanasius of Alexandria: Original Research and New Perspectives. Rollingsford, NH: Orthodox Research Institute, 2005.

Drake, H. A. "Athanasius' First Exile." Greek, Roman, and Byzantine Studies 27 (1986): 193204.

Drake, Susanna. Slandering the Jew: Sexuality and Difference in Early Christian Texts. Philadelphia: University of Pennsylvania Press, 2013.

Dunn, Geoffrey. "The Date of Innocent I's Epistula 12 and the Second Exile of John Chrysostom.” Greek, Roman, and Byzantine Studies 45 (2005): 155-70.

Dunning, Benjamin. Aliens \& Sojourners: Self as Other in Ancient Christianity. Philadelphia: University of Pennsylvania Press, 2009.

Duval, Y.-M. "Vrais et faux problèmes concernant le retour d'exil d'Hilaire de Poitiers et son action en Italie en 360-363." Athenaeum 48 (1970): 251-75.

Elm, Susanna. "The Dog That Did Not Bark: Doctrine and Patriarchal Authority in the Conflict Between Theophilus of Alexandria and John Chrysostom of Constantinople." In Christian Origins: Theology, Rhetoric and Community, edited by Lewis Ayres and Gareth Jones, 68-93. London: Routledge, 1998.

- Sons of Hellenism, Fathers of the Church: Emperor Julian, Gregory of Nazianzus, and the Vision of Rome. Berkeley: University of California Press, 2012.

- Virgins of God: The Making of Asceticism in Late Antiquity. New York: Oxford University Press, 1994.

— . "Waiting for Theodosius, or the Ascetic and the City: Gregory of Nazianzus on Maximus the Philosopher." In Ascetic Culture: Essays in Honor of Philip Rousseau, edited 
by Blake Leyerle and Robin Darling Young, 182-98. Notre Dame, IN: University of Notre Dame Press, 2013.

Elm, Susanna, Eric Rebillard, and Antonella Romano, eds. Orthodoxie, Christianisme, Histoire: Orthodoxy, Christianity, History. CÉFR 270. Rome: École francaise de Rome, 2000.

Endsjø, Dag Øistein. Primordial Landscapes, Incorruptible Bodies: Desert Asceticism and the Christian Appropriation of Greek Ideas on Geography, Bodies, and Immortality. New York: Lang, 2008.

Erdkamp, Paul. The Grain Market in the Roman Empire: A Social, Political, and Economic Study. Cambridge: Cambridge University Press, 2009.

Ernest, James D. The Bible in Athanasius of Alexandria. Leiden: Brill, 2004.

Errington, R. Malcolm. "Church and State in the First Years of Theodosius I." Chiron 27 (1997): 21-72.

Esteel, Bruno. "Nonplaces: An Anecdoted Topography of Contemporary French Theory." Diacritics 33, nos. 3-4 (2003): 117-39.

Faraone, C. "Magical and Medical Approaches to the Wandering Womb in the Ancient Greek World." Classical Antiquity 30, no. 1 (2011): 1-32.

Feder, Alfred. Bischofsnamen und Bischofssitze bei Hilarius: Kritische Untersuchungen zur kirchlichen Prosopographie und Topographie des 4. Jahrhunderts, vorgelegt in der Sitzung am 12. Oktober 1910. Vienna: Hölder, 1911.

. Studien zu Hilarius von Poitiers III. Vienna: Hölder, 1912.

Ferguson, Everett, ed. History, Hope, Human Language, and Christian Reality. New York: Taylor \& Francis, 1999.

Ferguson, John. Utopias of the Classical World. London: Thames \& Hudson, 1975.

Ferguson, Thomas. The Past Is Prologue: The Revolution of Nicene Historiography. Leiden: Brill, 2005.

Field, Lester L. On the Communion of the Damasus and Meletius: Fourth-Century Synodal Formulae in the Codex Veronensis LX. Ontario: Pontifical Institute of Mediaeval Studies, 2004.

Flower, Richard. Emperors and Bishops in Late Roman Invective. Cambridge: Cambridge University Press, 2015.

- "The Emperor's New Past: Re-Enactment and Inversion in Christian Invectives Against Constantius II.” In Unclassical Traditions, volume 1, Alternatives to the Classical Past in Late Antiquity, edited by Christopher Kelly, Richard Flower, and Michael Stuart Williams, 28-43. Cambridge: Cambridge University Press, 2010.

—. "Genealogies of Unbelief: Epiphanius of Salamis and Heresiological Authority." In Unclassical Traditions, volume 2, Perspectives from East and West in Late Antiquity, edited by Christopher Kelly, Richard Flower, and Michael Stuart Williams, 70-87. Cambridge: Cambridge Philological Society, 2011.

- Imperial Invectives against Constantius II. Liverpool: Liverpool University Press, 2016. Foucault, Michel. The Archaeology of Knowledge: And the Discourse on Knowledge. New York: Psychology Press, 2002.

—. "Of Other Spaces." Diacritics 16, no. 1 (1986): 22-27.

- Power/Knowledge: Selected Interviews and Other Writings 1972-1977. Translated by Colin Gordon. New York: Pantheon, 1977.

- "What Is an Author?" In The Foucault Reader, edited by Paul Rabinow, 205-22. London: Penguin, 1991. 
Fournier, Eric. "Constantine and Episcopal Banishment: Continuity and Change in the Settlement of Christian Disputes," In Hillner, Ulrich, and Engberg, Late Antique Clerics in Exile 47-66.

. "Exiled Bishops in the Christian Empire: Victims of Imperial Violence?" In Violence in Late Antiquity: Perceptions and Practices, 157-66. Hampshire, UK: Ashgate, 2006.

_. "Victor of Vita and the Vandal 'Persecution': Interpreting Exile in Late Antiquity." PhD. diss., University of California, Santa Barbara, 2008.

Fowden, Garth. "The Last Days of Constantine: Oppositional Versions and Their Influence." Journal of Roman Studies 84 (1994): 146-70.

Gaertner, Jan Felix. Introduction to Gaertner, Writing Exile, 1-20.

—. "Ovid and the 'Poetics of Exile': How Exilic Is Ovid's Exile Poetry." In Gaertner, Writing Exile, 155-72.

- ed. Writing Exile: The Discourse of Displacement in Greco-Roman Antiquity and Beyond. Leiden: Brill, 2007.

Gahan, John. "Seneca, Ovid, and Exile." Classical World 78, no. 3 (1985): 145-47.

Galling, Kurt, and Wilfrid Werbeck. Die Religion in Geschichte und Gegenwart: Handwörterbuch für Theologie und Religionswissenschaft. Tübingen: Mohr, 1959.

Garnsey, Peter. Social Status and Legal Privilege in the Roman Empire. Oxford: Clarendon, 1970.

Garnsey, Peter, and Caroline Humfress. The Evolution of the Late Antique World. Cambridge: Orchard Academic, 2001.

Gärtner, Hans Armin. "Synkrisis." Der Neue Pauly 3:8-34.

Gillett, Andrew. Envoys and Political Communication in the Late Antique West, 411-533. Cambridge: Cambridge University Press, 2003.

Girardet, Klaus M. Kaisergericht und Bischofsgericht: Studien zu den Anfängen des Donatistenstreites (313-315) und zum Prozess des Athanasius von Alexandrien (328-346). Bonn: Habelt, 1975.

Giroux, Henry A., and Kostas Myrsiades, eds. Beyond the Corporate University: Culture and Pedagogy in the New Millennium. Oxford: Rowman \& Littlefield, 2001.

Gleason, Maud. Making Men: Sophists and Self-Presentation in Ancient Rome. Princeton, NJ: Princeton University Press, 1995.

Goehring, James. "The Dark Side of the Landscape: Ideology and Power in the Christian Myth of the Desert." Journal of Medieval and Early Modern Studies 33, no. 3 (2003): 43751.

- "The Encroaching Desert: Literary Production and Ascetic Space in Early Christian Egypt." Journal of Early Christian Studies 1, no. 3 (1993): 281-96.

- "The Origins of Monasticism." In Eusebius, Christianity, and Judaism, edited by H. W. Attridge and G. Hata, 235-55. Detroit, MI: Wayne State University Press, 1992.

Goldhill, Simon, ed. Being Greek under Rome: Cultural Identity, the Second Sophistic and the Development of Empire. Cambridge: Cambridge University Press, 2007.

- The Poet's Voice: Essays on Poetics and Greek Literature. Cambridge: Cambridge University Press, 1991.

Grasmück, Ernst Ludwig. Exilium: Untersuchungen zur Verbannung in der Antike. Paderborn: Schoningh, 1978.

Gregg, Robert C. Athanasius: Life of Antony and Letter to Marcellus. Mahwah, NJ: Paulist, 1977. 
Grig, Lucy, and Gavin Kelly. "From Rome to Constantinople." In Two Romes: Rome and Constantinople in Late Antiquity, edited by Lucy Grig and Gavin Kelly, 3-30. Oxford: Oxford University Press, 2010.

Gwynn, David M. Athanasius of Alexandria: Bishop, Theologian, Ascetic, Father. Oxford: Oxford University Press, 2012.

- Christianity in the Later Roman Empire: A Sourcebook. London: Bloomsbury, 2015.

- The Eusebians: The Polemic of Athanasius of Alexandria and the Construction of the "Arian Controversy." Oxford: Oxford University Press, 2007.

Haas, Christopher. Alexandria in Late Antiquity: Topography and Social Conflict. Baltimore, MD: Johns Hopkins University Press, 1997.

Hägg, Tomas, Philip Rousseau, and Christian Høgel, eds. Greek Biography and Panegyric in Late Antiquity. Berkeley: University of California Press, 2000.

Hahn, Johannes. "The Conversion of the Cult Statues: The Destruction of the Serapeum 392 A.D. and the Transformation of Alexandria into the 'Christian Loving' City." In From Temple to Church: Destruction and Renewal of Local Cultic Topography in Late Antiquity, edited by Johannes Hahn, Stephen Emmel, and Ulrich Gotter, 335-65. Leiden: Brill, 2008.

Hansen, G. C. Sozomenus Kirchengeschichte. 2nd ed. Griechischen Christlichen Schriftsteller 4. Berlin: Akademie Verlag, 1995.

Hanson, A. E. “The Gradualist View of Fetal Development." In Lembryon: formation et animation; antiqué grecque et latine tradition he'braï, chrétienne et islamique, edited by L. Brisson, M.-H. Congourdeau, and J.-L. Solère, 95-108. Paris: Librairie Philososophique, 2008. "Hippocrates: 'Diseases of Women 1.' Signs 1, no. 2 (1975): 567-84.

Harries, Jill. Law and Empire in Late Antiquity. Cambridge: Cambridge University Press, 2001.

Hartney, Aideen. M. John Chrysostom and the Transformation of the City. London: Duckworth, 2004 .

Heikel, I. A. Eusebius Werke. 7 vols. Die Griechischen Christlichen Schriftsteller 7. Leipzig: Hinrichs, 1902.

Herbich, Tomasz, Darlene Brooks Hedstrom, and Stephen J. Davis. "A Geophysical Survey of Ancient Pherme: Magnetic Prospection at an Early Christian Monastic Site in the Egyptian Delta." Journal of the American Research Center in Egypt 44 (2007): 129-37.

Hihn, Oliver. "The Election and Deposition of Meletius of Antioch: The Fall of an Integrative Bishop." In Episcopal Elections in Late Antiquity. Edited by Johan Leemans, Peter Van Nuffelen, Shawn W. J. Keough, and Carla Nicolaye, 357-74. Arbeiten zur Kirchengeschichte 119. Berlin: de Gruyter, 2011.

Hillner, Julia. "Fifth-Century Church Historians: Social Network Analysts Before Their Time?" Migration of Faith (blog). April 1, 2016. http://www.hrionline.ac.uk/sites/clericalexile/2016/04/o1/fifth-century-church-historians-social-network-analysts-beforetheir-time/.

- Introduction to Hillner, Ulrich, and Engberg, Late Antique Clerics in Exile, 11-43.

- Prison, Punishment, and Penance in Late Antiquity. Cambridge: Cambridge University Press, 2015.

Hillner, Julia, Jörg Ulrich, and Jakob Engberg, eds. Late Antique Clerics in Exile. New York: Peter Lang, 2016. 
Hodkinson, Owen. "Better Than Speech: Some Advantages of the Letter in the Second Sophistic." In Letters: Classical and Late Antique Epistolography, edited by Ruth Morello and A. D. Morrison, 283-300. Oxford: Oxford University Press, 2007.

Holum, K. G. Theodosian Empresses: Women and Imperial Dominion in Late Antiquity. Berkeley: University of California Press, 1982.

Hubbard, Phil, Rob Kitchin, and Gill Valentine, eds. Key Thinkers on Space and Place. London: SAGE, 2004.

Humfress, Caroline. Orthodoxy and the Courts. Oxford: Oxford University Press, 2007.

Iricinschi, Eduard, and Holger Zellentin, eds. Heresy and Identity in Late Antiquity. Tübingen: Mohr Siebeck, 2008.

Jacobs, Andrew. Christ Circumcised: A Study in Early Christian History and Difference. Philadelphia: University of Pennsylvania Press, 2012.

- Epiphanius of Cyprus: A Cultural Biography of Late Antiquity. Christianity in Late Antiquity Series. Berkeley: University of California Press, 2016.

Judge, E. A. The Earliest Use of Monachos for "Monk" and the Origins of Monasticism. Münster: Aschendorffsche Verlagsbuchhandlung, 1977.

Kannengiesser, C. “The Athanasian Decade 1974-1984." Theological Studies 46 (1985): 524-41.

Karmann, Thomas. "Johannes Chrysostomus under der Neunäznismus. Eine Spurensuche in ausgewählten Predigten des antiochenischen Presbyters." Sacris Erudiri 51 (2012): 79-108.

- Meletius von Antiochien. Studien zur Geschichte des trinitätstheologischen Streits in den Jahren 360-364 n. Chr. RST 68. New York: Peter Lang, 2009.

Katos, Demetrios S. Palladius of Helenopolis: The Origenist Advocate. Oxford: Oxford University Press, 2011.

Kelly, Gordon. A History of Exile in the Roman Republic. Cambridge: Cambridge University Press, 2006.

Kelly, J. N. D. Golden Mouth: The Story of John Chrysostom-Ascetic, Preacher, Bishop. Ithaca, NY: Cornell University Press, 1998.

Kim, Young Richard. Epiphanius of Cyprus: Imagining an Orthodox World. Ann Arbor: University of Michigan Press, 2015.

King, H. Hippocrates' Women: Reading the Female Body in Ancient Greece. New York: Routledge, 1998.

Kloos, Rudolph M. “The Paleography of the Inscriptions of San Marco.” In The Mosaics of San Marco in Venice: The Eleventh and Twelfth Centuries, volume 1, edited by Otto Demus, 295-385. Chicago: University of Chicago Press, 1984.

Konstan, David. "How to Praise a Friend: St. Gregory of Nazianzus's Funeral Oration for St. Basil the Great," In Greek Biography and Panegyric in Late Antiquity, edited by Tomas Hägg, 160-79. Berkeley: University of California Press, 2000.

Kosinski, Rafal. "The Exiled Bishops of Constantinople from the Fourth to the Late Sixth Century." Studia Ceranea 5 (2015): 231-47.

Krueger, Derek. Writing and Holiness: The Practice of Authorship in the Early Christian East. Philadelphia: University of Pennsylvania Press, 2004.

Lada-Richards, Ismene. “'By Means of Performance': Western Greek Mythological VasePaintings, Tragic 'Enrichment', and the Early Reception of Fifth-century Athenian Tragedy." Arion 17, no. 2 (2009): 99-166. 
Lallemand, Jacqueline. L'administration civile de l'Egypte de l'avènement de Dioclétien à la création du diocèse (284-382): Contribution à l'étude des rapports entre l'Egypte et l'Empire à la fin du IIIe siècle et au IVe siècle. Brussels: Palais des Académies, 1964.

Le Boulluec, Alain. Le notion d'heresie dans la litterature grecque IIe-IIIe siecles. Paris: Etudes Augustiniennes, 1985.

Leemans, J., W. Mayer, P. Allen, and B. Dehandschutter. Let Us Die That We May Live: Greek Homilies on Christian Martyrs from Asia Minor, Palestine and Syria c. AD 350-AD 450. London: Routledge, 2003.

Leppin, Hartmut. Theodosius der Große: Auf dem Weg zum christlichen Imperium. Darmstadt: Primus, 2003.

Lieu, Judith. Christian Identity in the Jewish and Graeco-Roman World. New York: Oxford University Press, 2004.

Lieu, Samuel, and Dominc Montserrat, eds. From Constantine to Julian: Pagan and Byzantine Views: A Source History. New York: Routledge, 1996.

Lim, Richard. "Christian Triumph and Controversy." In Late Antiquity: A Guide to the Postclassical World, edited by G. W. Bowersock, Peter Brown, and Oleg Grabar, 196-218. Cambridge, MA: Harvard University Press, 1999.

- Public Disputation, Power, and Social Order in Late Antiquity. Berkeley: University of California Press, 1995.

Long, Jacqueline. Claudian's In Eutropium: Or, How, When, and Why to Slander a Eunuch. Chapel Hill: University of North Carolina Press, 1996.

Luckritz Marquis, Timothy. Transient Apostle: Paul, Travel, and the Rhetoric of Empire. New Haven, CT: Yale University Press, 2013.

Lyman, J. Rebecca. "2002 NAPS Presidential Address: Hellenism and Heresy." Journal of Early Christian Studies 11, no. 2 (2003): 209-22.

- Christology and Cosmology: Models of Divine Activity in Origen, Eusebius, and Athanasius. Oxford: Clarendon, 1993.

—. "A Topography of Heresy: Mapping the Rhetorical Creation of Arianism." In Arianism after Arius: Essays on the Development of the Fourth Century Trinitarian Conflicts, edited by Michel R. Barnes and Daniel H. Williams, 45-62. Edinburgh: T \& T Clark, 2000.

Machado, Carlos. "Aristocratic Houses and the Making of Late Antique Rome and Constantinople." In Two Romes: Rome and Constantinople in Late Antiquity, edited by Lucy Grig and Gavin Kelly, 136-58. Oxford: Oxford University Press, 2012.

Malherbe, A. "Medical Imagery in the Pastoral Epistles." In Texts and Testaments: Critical Essays on the Bible and Early Church Fathers in Honor of Stuart Dickson Currie, edited by W. Eugene March, 19-35. San Antonio, TX: Trinity University Press, 1980.

Malingrey, Anne-Marie, ed. Palladios, Dialogue sur la vie de Jean Chrysostome, 2 vols. With Philippe Leclercq. SC 341-42. Paris: Paillart, 1988.

Malkki, L. "National Geographic: The Rooting of Peoples and the Territorialization of National Identity among Scholars and Refugees." Cultural Anthropology 71, no. 1 (1992): 24-44.

Mardorossian, Carine M. "From Literature of Exile to Migrant Literature." Modern Language Studies 32.2 (2002): 15-33.

Martin, Dale. Introduction to Miller and Martin, Cultural Turn, 1-24. 
Mayer, Wendy. "Antioch and the Intersection between Religious Factionalism, Place and Power." In The Power of Religion in Late Antiquity, edited by A. Cain and N. Lenski, 357-67. Aldershot, UK: Ashgate, 2009.

. "Antioch and the West in Late Antiquity." Byzantinoslavica 61 (2003): 5-32.

. "The Bishop as a Crisis Manager: An Exploration of Early Fifth-Century Episcopal Strategy." In Studies of Religion and Politics in the Early Christian Centuries, edited by David Luckensmeyer and Pauline Allen, 151-71. Early Christian Studies 13. Strathfield, Australia: St Paul's, 2010.

- "Cathedral Church of Cathedral Churches?" Orientalia Christiana Periodica 66 (2000): 49-68.

- "Constantinopolitan Women in Chrysostom's Circle." Vigiliae Christianae 53, no. 3 (1999): 265-88.

. The Cult of the Saints: St. John Chrysostom. Crestwood, NY: St. Vladimir's Seminary Press, 2006.

- "Doing Violence to the Image of an Empress: The Destruction of Eudoxia's Reputation." In Violence in Late Antiquity: Perceptions and Practices, edited by H. A. Drake, 205-14. Aldershot, UK: Ashgate, 2006.

- "John Chrysostom as Bishop: The View from Antioch." Journal of Ecclesiastical History 55 , no. 3 (2004): 455-66.

- "John Chrysostom as Crisis Manager: The Years in Constantinople." In Ancient Jewish and Christian Texts as Crisis Management Literature: Thematic Studies from the Centre for Early Christian Studies, edited by D. Sim and P. Allen, 129-42. LNTS 445. London: T \& T Clark, 2012.

- "John Chrysostom: Deconstructing the Construction of an Exile." Theologische Zeitschrift 62, no. 2 (2006): 248-58.

- "The Making of a Saint: John Chrysostom in Early Historiography." In Chrysostomosbilder in 1600 Jahren: Facetten der Wirkungsgeschichte eines Kirchenvaters, edited by M. Wallraff and R. Brändle, 39-59. Arbeiten zur Kirchengeschichte 105. Berlin: de Gruyter, 2008.

—. "Media Manipulation as a Tool in Religious Conflict: Controlling the Narrative Surrounding the Deposition of John Chrysostom." In Religious Conflict from Early Christianity to Early Islam, edited by W. Mayer and B. Neil, 151-68. Arbeiten zur Kirchengeschichte 121. Berlin: de Gruyter, 2013.

Mayer, Wendy, and Pauline Allen. John Chrysostom. London: Routledge, 2000.

McGuckin, John. "Aliens and Citizens of Elsewhere: 'Xeniteia' in East Christian Monastic Literature." In Strangers to Themselves: The Byzantine Outsider, edited by Dion C. Smythe, 23-38. Aldershot, UK: Variorum, 2000.

McHugh, Patrick. "Ecstasy and Exile: Cultural Theory between Heidegger and Adorno." Cultural Critique 25 (1993): 121-52.

McLynn, Neil. "Gregory Nazianzen's Basil: The Literary Construction of a Christian Friendship." Studia Patristica 37 (2001): 178-93.

_ . "Moments of Truth: Gregory of Nazianzus and Theodosius I." In From the Tetrarchs to the Theodosians: Later Roman History and Culture, 284-45o CE, edited by Scott McGill, Cristiana Sogno, and Edward Watts, 215-40. Yale Classical Studies 34. Cambridge: Cambridge University Press, 2010. 
. "Two Romes, Beacons of the Whole World: Canonizing Constantinople." In Two Romes: Rome and Constantinople in Late Antiquity, edited by Lucy Grig and Gavin Kelly, 345-63. Oxford: Oxford University Press, 2012.

Mena, P. "Insatiable Appetites: Epiphanius of Salamis and the Making of the Heretical Villain." Studia Patristica 67 (2013): 257-64.

Meyer, Robert T. (ed. and trans.). Palladius: Dialogue on the Life of St. John Chrysostom. ACW 45. New York: Newman, 1985.

Miller, Patricia Cox. Biography in Late Antiquity: A Quest for the Holy Man. Berkeley: University of California Press, 1983.

Miller, Patricia Cox, and Dale Martin, eds. The Cultural Turn in Late Ancient Studies: Gender, Asceticism, and Historiography. Durham, NC: Duke University Press, 2005.

Molloy, M. E. Champion of Truth: The Life of Saint Athanasius. New York: Alba House, 2003.

Momigliano, Arnaldo. The Development of Greek Biography. Cambridge, MA: Harvard University Press, 1993.

Mommsen, Theodore. Römisches Strafrecht. Graz: Akademische Druck- und Verlagsantstalt, 1955 .

Montiglio, Sylvia. Wandering in Ancient Greek Culture. Chicago: University of Chicago Press, 2005.

Morello, Ruth, and A. D. Morrison, eds. Ancient Letters: Classical and Late Antique Epistolography. Oxford: Oxford University Press, 2007.

Moss, Candida. Ancient Christian Martyrdom: Diverse Practices, Theologies, and Traditions. New Haven, CT: Yale University Press, 2012.

Motto, Anna Lydia, and John R. Clark. "The Monster in Seneca's Hercules Furens." Classical Philology 89, no. 3 (1994): 269-72.

Muehlberger, Ellen. “The Legend of Arius' Death: Imagination, Space, and Filth in Late Ancient Historiography." Past and Present 277 (2015): 3-29.

Napran, Laura, and Elizabeth van Houts, eds. Exile in the Middle Ages. Turnhout: International Medieval Research, 2004.

Negley, Glenn Robert. Utopian Literature: A Bibliography with a Supplementary Listing of Works Influential in Utopian Thought. Lawrence: Regents Press of Kansas, 1977.

Negley, Glenn Robert, and John Max Patrick. The Quest for Utopia. Ann Arbor, MI: McGrath, 1971.

Nussbaum, M. “Therapeutic Arguments: Epicurus and Aristotle." In The Norms of Nature: Studies in Hellenistic Ethics, edited by M. Schofield and G. Striker, 31-74. Cambridge: Cambridge University Press, 1986.

Opitz, Hans-Georg, ed. Athanasius Werke II, volume 1, part 1, Die Apologien (Lfg. 1-7). Berlin: de Gruyter, 1940.

Orlandi, Tito. "The Coptic Ecclesiastical History." In The World of Early Egyptian Christianity: Language, Literature, and Social Context, edited by James E. Goehring and Janet Timbie, 3-24. Washington DC: Catholic University of America Press, 2007.

Parmentier, L., F. Scheidweiler, and G. C. Hansen. Theodoretus Cyri, Kirchengeschichte. 3rd ed. Griechischen Christlichen Schriftsteller 19. Berlin: Akademie Verlag, 1998.

Parvis, Sara. Marcellus of Ancyra and the Lost Years of the Arian Controversy 325-345. Oxford: Oxford University Press, 2006.

Pazdernik, Charles F. "'How Then Is It Not Better to Prefer Quiet, Than the Dangers of Conflict?' The Imperial Court as the Site of Shifting Cultural Frontiers.” In Shifting Cultural 
Frontiers in Late Antiquity, edited by David Brakke, Deborah Mauskopf Deliyannis, and Edward Jay Watts, 99-111. Burlington, VT: Ashgate, 2012.

Perkins, Judith. The Suffering Self: Pain and Narrative Representation in the Early Christian Era. New York: Routledge, 1995.

Peters, Paul. "Comment Saint Athanase s'enfuit de Tyr en 335." Bulletin de l'Académie Royale de Belgique 30 (1994): 131-77.

Philostorgius. Kirchengeschichte. Mit dem Leben des Lucian von Antiochien und den Fragmenten eines arianischen Historiographen. Edited by Joseph Bidez. Revised by Friedhelm Winkelmann. GCS. Berlin: Akademie Verlag, 1981.

Pietri, Charles. Roma Christiana. Recherches sur l'Eglise de Rome, son organisation, sa politique, son idéologie de Miltiade à Sixte III (311-440). 2 vols. Rome: École Francaise, 1976.

Pippin, T. “Jezebel Re-Vamped." In A Feminist Companion to Samuel and Kings, edited by A. Brenner, 196-206. Feminist Companion to the Bible. Sheffield, UK: Sheffield Academic, 1994.

Rapp, Claudia. Holy Bishops in Late Antiquity: The Nature of Christian Leadership in an Age of Transition. Berkeley: University of California Press, 2005.

Rasmussen, Adam. "Basil of Caesarea's Uses of Origen in His Polemic against Astrology." Zeitschrift für Antikes Christentum C 18, no. 3 (2014): 471-85.

Reinkens, J. H. Hilarius von Poitiers. Schaffhausen: Hurter, 1864.

Reis, David. “The Rhetoric of Exile." Paper presented at the Annual Meeting of the Society of Biblical Literature. Atlanta, GA. November 20, 2010.

Robatha, D. M. “Ovid in the Middle Ages." In Ovid, edited by J. W. Binns, 191-209. London: Routledge and Kegan Paul, 1973.

Roberts, Michael. "The Last Epic of Antiquity: Generic Continuity and Innovation in the Vita Sancti Martini of Venantius Fortunatus." Transactions of the American Philological Association 131 (2001): 257-85.

Roller, Duane. The Geography of Strabo: An English Translation, with Introduction and Notes. Cambridge: Cambridge University Press, 2014.

Rousseau, Philip. Basil of Caesarea. Berkeley: University of California Press, 1998.

- Pachomius: The Making of a Community in Fourth-Century Egypt. Berkeley: University of California Press, 1985.

Said, Edward. Reflections on Exile and Other Essays. Cambridge, MA: Harvard University Press, 2000.

Sandwell, Isabella. Religious Identity in Late Antiquity: Greeks, Jews, and Christians in Antioch. Cambridge: Cambridge University Press, 2007.

Schanz, Martin von. Geschichte der römischen Literatur, bis zum Gesetzgebungswerk des Kaisers Justinian. Munich: Beck, 1927.

Schatkin, Margaret Amy. John Chrysostom as Apologist. Thessaloniki: Patriarchikon Hidryma Paterikon Meleton, 1987.

Schatkin, Margaret Amy, and Paul W. Harkins, trans. Saint John Chrysostom: Apologist. FC 73. Washington DC: Catholic University of America Press, 1987.

Schneider, Walter. "Creating a Metropolis: A Comparative Demographic Perspective." In Ancient Alexandria between Egypt and Greece, edited by William V. Harris and Giovanni Ruffini, 1-31. Leiden: Brill, 2004.

Schor, Adam. Theodoret's People: Social Networks and Religious Conflict in Late Roman Syria. Berkeley: University of California Press, 2011. 
Schott, Jeremy. Christianity, Empire, and the Making of Religion in Late Antiquity. Philadelphia: University of Pennsylvania Press, 2008.

Scott, James M. "Exile and the Self-Understanding of Diaspora Jews in the Greco-Roman Period." In Exile: Old Testament, Jewish, and Christian Conceptions, edited by James M. Scott, 173-218. Leiden: Brill, 1997.

Seidel, Michael. Exile and the Narrative Imagination. New Haven, CT: Yale University Press, 1986.

Sessa, Kristina. The Formation of Papal Authority in Late Antique Italy: Roman Bishops and the Domestic Sphere. New York: Cambridge University Press, 2012.

Shaw, Brent D. "Body/Power/Identity: Passions of the Martyrs." Journal of Early Christian Studies 4, no. 3 (1996): 269-312.

Shaw, Teresa. "Ascetic Practice and the Genealogy of Heresy: Problems in Modern Scholarship and Ancient Textual Representation." In Miller and Martin, Cultural Turn, $213-36$.

Shepardson, Christine. "The City, a Text: Inscribing Orthodoxy in Antioch's Landscape." Paper presented at the North American Patristics Conference, Chicago, IL, May 23, 2013.

_ . "Controlling Contested Places: John Chrysostom's Adversus Iudaeos Homilies and the Spatial Politics of Religious Controversy." Journal of Early Christian Studies 15, no. 4 (2007): 483-516.

- Controlling Contested Places: Late Antique Antioch and the Spatial Politics of Religious Controversy. Berkeley: University of California Press, 2014.

- "Rewriting Julian's Legacy: John Chrysostom's On Bablyas and Libanius' Oration 24." Journal of Late Antiquity 2, no. 1 (2009): 99-115.

Simonetti, Manlio. "Note Sulla Struttura e La Cronologia Del 'De Trinitate' Di Ilario Di Poitiers." Studi Urbanita (1965): 274-300.

Sizgorich, Thomas. Violence and Belief in Late Antiquity: Militant Devotion in Christianity and Islam. Philadelphia: University of Pennsylvania Press, 2008.

Smarr, J. L. "Poetics of Love and Exile." In Dante and Ovid: Essays in Intertextuality, edited by M. U. Sowell, 139-51. Medieval and Renaissance Texts and Studies 82. Binghamton: State University of New York at Binghamton, 1991.

Soja, Edward W. Thirdspace: Journeys to Los Angeles and Other Real-and-Imagined Places. Malden, MA: Blackwell, 1996.

Stancliffe, Clare. St. Martin and His Hagiographer: History and Miracle in Sulpicius Severus. Oxford: Clarendon, 1983.

Stini, Frank. Plenum exiliis mare: Untersuchungen zum Exil in der römischen Kaiserzeit. Stuttgart: Franz Steiner Verlag, 2011.

Storin, Bradley. "In a Silent Way: Asceticism and Literature in the Rehabilitation of Gregory of Nazianzus." Journal of Early Christian Studies 19, no. 2 (2011): 225-57.

- "The Letter Collection of Gregory of Nazianzus." In Late Antique Letter Collections: A Critical Introduction and Reference Guide, edited by Cristiana Sogno, Bradley K. Storin, and Edward J. Watts, 81-101. Berkeley: University of California Press, 2017.

Straub, J. "Constantine as Koinos Episkopos: Tradition and Innovation in the Representation of the First Christian Emperor's Majesty." Dumbarton Oaks Papers 21 (1967): 37-55.

Tetz, Martin. "Zur Biographie des Athanasius von Alexandrien." Zeitschrift für Kirchengeschichte 90 (1979): 158-92. 
Tiersch, Claudia. Johannes Chrysostomus in Konstantinopel (398-404). Weltsicht und Wirken eines Bischofs in der Hauptstadt des Oströmischen Reiches. Studien und Texte zu Antike und Christentum 6. Tübingen: Mohr Siebeck 2002.

Trible, P. “The Odd Couple: Elijah and Jezebel." In Out of the Garden: Women Writers on the Bible, edited by C. Büchmann and C. Spiegel, 166-79. New York: Ballantine, 1994.

Trout, Dennis. "Amicitia, Auctoritas, and Self-Fashioning Texts: Paulinus of Nola and Sulpicius Severus." Studia Patristica 28 (1993): 123-29.

- Paulinus of Nola: Life, Letters, and Poems. Berkeley: University of California Press, 1999.

Tuan, Yi-Fu. Space and Place: The Perspective of Experience. Minneapolis: University of Minnesota Press, 1977.

- Topophilia: A Study of Environmental Perception, Attitudes, and Values. Englewood Cliffs, NJ: Prentice Hall, 1974.

Urbainczyk, Theresa. Theodoret of Cyrrhus: The Bishop and the Holy Man. Ann Arbor: University of Michigan Press, 2002.

Van Andel, G. K. "Sulpicius Severus and Origenism." Vigiliae Christianae 34 (1980): 278-87.

Van Dam, Raymond. Remembering Constantine at the Milvian Bridge. New York: Cambridge University Press, 2011.

Van Nuffelen, Peter. "Episcopal Succession in Constantinople (381-450 C.E.): The Local Dynamics of Power." Journal of Early Christian Studies 18, no. 3 (2010): 425-51.

—. "Palladius and the Johannite Schism." Journal of Ecclesiastical History 64 (2013): 1-19.

Ommeslaeghe, Florent van. "De lijkrede voor Johannes Chrysostomus, toegeschreven aan Martyrius van Antiochie: Tekstuitgave met commentaar, hoofdstukken uit de historische kritiek." PhD diss., Katholieke Universiteit te Leuven, 1974.

_. "La fête de S. Jean Chrysostome dans l'église grecque." Analecta Bollandiana 96 (1978): 38 .

—_ "Que vaut le témoignage de Pallade sur le procès de s. Jean Chrysostome?” Analecta Bollandiana 95 (1977): 389-413.

Veness, A. R. "Home and Homelessness in the United States: Changing Ideals and Realities." Environment and Planning D: Society and Space 10, no. 4 (1992): 445-68.

Vieira, Fatima. “The Concept of Utopia." In The Cambridge Companion to Utopian Literature, edited by Gregory Claeys, 3-27. Cambridge: Cambridge University Press, 2010.

Vivian, Tim. The Life of Antony: The Greek and Coptic Lives, with an Encomium on Saint Antony of Egypt. Kalamazoo, MI: Cistercian, 2003.

Vivian, Tim, and Apostolos N. Athanassakis (trans.). Athanasius of Alexandria: The Life of Antony. The Coptic Life, and the Greek Life. With Rowan A. Greer. Cistercian Studies Series 202. Kalamazoo, MI: Cistercian, 2003.

Von Hase, Karl August. Kirchengeschichte: Lehrbuch Zunächst für Academische Vorlesungen. 2nd ed. Liepzig: Breitkopf und Härte, 1836.

Walker, Denise. "The Displaced Self: The Experience of Atopia and the Recollection of Place." Mosaic: A Journal for the Interdisciplinary Study of Literature 36, no. 1 (2003): 21-33.

Wallraff, Martin. "Geschichte des Novatianismus seit dem vierten Jahrhundert im Osten." Zeitschrift für Antikes Christentum 1 (1997): 251-79.

Wallraff, M., ed., and C. Ricci, trans., Ps.-Martyrius, Oratio funebris in laudem sancti Iohannis Chrysostomi: epitaffio attribuito a Martirio di Antiochia (BHG 871, CPG 6517). 
Quaderni della Rivista di bizantinistica 12. Spoleto, Italy: Fondazione Centro italiano di studi sull'Alto Medioevo, 2007.

Walter, Ferdinand. Geschichte des Römischen Rechts bis auf Justinian. Bonn: Weber, 1861.

Wand, J. W. C. The Greek \& Latin Doctors. Edited by John H. Morgan. Bristol, IN: Wyndham Hall, 1990.

Washburn, Daniel. Banishment in the Later Roman Empire, 284-476 C.E. New York: Routledge, 2013.

—. "The Letter Collection of John Chrysostom." In Late Antique Letter Collections: A Critical Introduction and Reference Guide, edited by Cristiana Sogno, Bradley K. Storin, and Edward J. Watts, 190-204. Oakland: University of California Press, 2016.

Watts, Edward. "Interpreting Catastrophe: Disasters in the Works of Pseudo-Joshua the Stylite, Socrates Scholasticus, Philostorgius, and Timothy Aelurus." Journal of Late Antiquity 2, no. 1 (2009): 79-98.

Weedman, Mark. "Not the Athanasius of the West: Hilary's Changing Relationship with Athanasius." Studia Patristica 42 (2006): 411-15.

. The Trinitarian Theology of Hilary of Poitiers. Leiden: Brill, 2007.

Weinandy, Thomas Gerard. Athanasius: A Theological Introduction. Aldershot, UK: Ashgate, 2007.

Weingarten, H. "Der Ursprung des Mönchtums im nachconstantinischen Zeitalter." Zeitschrift für Kirchengeschichte 1 (1877): 11-35.

Weingarten, Susan. The Saint's Saints: Hagiography and Geography in Jerome. Leiden: Brill, 2005.

Whiston, William. The Works of Flavius Josephus: Complete and Unabridged. Peabody, MA: Hendrickson, 1989.

Whitmarsh, Timothy. "'Greece in the World': Exile and Identity in the Second Sophistic." In Goldhill, Being Greek under Rome, 269-305.

- Greek Literature and the Roman Empire: The Politics of Imitation. Oxford: Oxford University Press, 2001.

- The Second Sophistic. Oxford: Oxford University Press, 2005.

Wickham, L. R., and Alfred Feder. Hilary of Poitiers' Conflicts of Conscience and Law in the Fourth-Century Church: Against Valens and Ursacius: The Extant Fragments, Together with His Letter to the Emperor Constantius. Liverpool: Liverpool University Press, 1997.

Williams, D. H. "A Reassessment of the Early Career and Exile of Hilary of Poitiers." Journal of Ecclesiastical History 42, no. 2 (1991): 202-17.

- "A Reassessment of the Early Career and Exile of Hilary of Poitiers." In Ferguson, History, Hope, Human Language, and Christian Reality, 338-54.

Williams, Gareth. Banished Voices: Readings in Ovid's Exile Poetry. Cambridge: Cambridge University Press, 1994.

Williams, Jeffrey. The Institution of Literature. New York: SUNY Press, 2002.

Young, Robyn Darling. "Xeniteia According to Evagrius of Pontus." In Ascetic Culture: Essays in Honor of Philip Rousseau, edited by Blake Leyerle and Robin Darling Young, 229-52. Notre Dame, IN: University of Notre Dame Press, 2013. 


\section{N D E X}

Abraham, 46, 99

Adomnan of Iona, 9

Adorno, Theodor, 174

Alexander of Alexandria, 37, 133, 136, 140, 142,150

Alexander of Constantinople, 61, 146, 150

Alexander the Great, 33

Alexandria, 32-34, 69, 79; and Antioch, 29, 149; Arian controversy in, 36, 142, 150; and Arius, 143, 145; and Athanasius, 3-4, 24, 32, $36,41,43,55,70,73,74,125-26,164-65$; and Constantinople, 124, 127-28, 131; ecclesiastical conflict in, 34-36; and Eusebius of Nicomedia, 136, 147; Great Church, 125-26, 147; and Gregory of Cappadocia, 125-26, 147; and Gregory of Nazianzus, 57, 70-71, 75; and John Chrysostom, 87, 92; and Meletius, 81; Nitrian monks in, 120-21; as orthodox space, 23-24, 27, 36; Sozomen on, 161, 164-65; Theodoret of Cyrrhus on, 150

Andrew, 59, 140

Antioch, 69-70, 133; and Alexandria, 29, 149; and Babylas, 157-60; and Basil of Caesarea, 64; Council of, 3, 4, 60, 63, 129n68; ecclesiastical conflict in, 64-65, 79-80, 151, 169-70; and Eusebius of Nicomedia, 147; and Meletius, 29, 81-84, 157, 168-69, 171-72; and John Chrysostom, 77-79, 81-85, 157-60, 167-68; and Julian, 158-60; Sozomen on, 161-63, 166-67; Synod of, 152, 163; Theodoret of Cyrrhus on, 149-52, 155-56
Antiochus IV, 106

anti-wanderer, 42

Antony, 49-54, 167

Apocryphon of James, 15

Apollo, 110, 159n12

Arcadius, 78, 105-106, 128, 130, 144

Arianism, 36, 71, 104, 142, 150, 152

Arians, 38-41, 43-45, 47-49, 62, 105, 125, 129, 146, $148,151,155-56,163,165-66,168-69$

Arius, 36, 61, 71, 107, 129, 136, 138, 143-46, 148

Arles, 18

Arsacius, 115

Arsenius, 3, 145

Artemis, 110

Asia Minor, 58, 60, 64, 79, 133

askesis, 26, 49, 50-51, 54, 66, 70, 72-73

Athalia, 110n24

Athanasius of Alexandria, 26, 31-32, 63, 177; and Alexandria, 24, 36; and Antioch, 148-49; and Arians, 36, 39, 42-45, 47-49; on ascetic withdrawal, 53; on askesis, 49, 50-51, 54; Athanasian creed, 161; on bishops, xiii, 53; career, 37; and church fathers, 45-47, 58; and Constantinople, 130-31; Defense before Constantius, 32, 37-44, 62, 126; Defense of His Flight, 32, 44-49, 62, 126; and the desert, 32, 38-40, 49-55; Encyclical Letter, 62, 125-27; and Eusebius of Nicomedia, 136; exile, 2-5, $32,37,42-44,72-73,125-27,130,162,164-65$, 175-77; on exile of Eustathius, 79; and John Chrysostom, 105, 127-31; Letter to Serapion, 
107; Life of Antony, 32, 49-54, 70, 72-73; on the logos, 47; on martyrs, 45-46; On the Incarnation, 50; On the Synod, 64, 138; Philostorgius on, 140; Socrates of Constantinople on, 144-45, 147-48; Sozomen on, 164-65; Tome of Antioch, 64

Athens, Xv, 57, 67

atopia, 118

Atticus, 117, 171

Augustine of Hippo, 8, 9, 31

Augustus of the West, 20

Auxentius of Milan, $41 \mathrm{n} 28$

Auxum, 41

Auxumis, 41

Babylas, 157-63, 172

Basilica di San Marco, 175

Basil of Caesarea, 57-58, 64-69, 74-75, 166

Berytus, 138, 150

Bithynia Prima, 133

Bithynia Secunda, 133

Boethius, 9

Byzantium, 135, 143, 147n41

Cadmus, 16

Caesarea, 57, 68, 75, 94-95

Caesarea Maritima, 57

Caesarius, 57

Cain, 99, 102

Canopica Way, 33

Cappadocia, 41n28, 71-72, 140, 166

Cappadocian fathers, 58. See also Basil of Caesarea, Gregory of Nazianzus, Gregory of Nyssa

Caracalla, 6

Carterius, 78

Christ, xv, 46, 74, 100, 122, 175

Christian-insider, 7

Christological controversies, 29, 149, 152

church fathers, 44-47, 58, 87, 92, 104

Church of the Martyrs, 36

Cicero, 11-12, 55n6o

citizenship, 6-7, 13-16

Claudian, $78 \mathrm{n} 6$

Claudius, 7, 97

Clodius, 11-12

Columba, 9

Constans, 3n9, 38, 137, 140, 165

Constantia, 137, 144-45

Constantine, 1, 6; and Athanasius, 2-4, 145; bones of, 59; column of, 144, 146; and Constantinople, 59-60, 118; and Eusebius of Nicomedia, 137, 140-41, 145, 147-48, 152; and
Nicomedia, 133-36; Philostorgius on, 139-41; Socrates of Constantinople on, 142-47; Speech to the Assembly of Saints, 134-35; Theodoret on, 150

Constantine II, 4, 140

Constantinople, 23, 27, 58-60, 167; and Athanasian legacy, 127-28, 130-31, 148, 177; contested patriarchate, 61-62; Council of, 1 , $63,81-83,87$; death of Arius in, 146; death of Meletius in, 81, 83-84; and Eudoxius, 155; and Eusebius of Nicomedia, 152; grain trade of, 3 ; Great Church, 140; and Gregory of Nazianzus, 58, 60-63, 69, 74-75; Hagia Sophia, 59, 91; Johanite conflict in, 20-21; and John Chrysostom, 24-25, 27, 76, 78-79, 85-91, 93-96, 101-102, 118-19, 124; as New Rome, 58n6, 87, 143; Novatians in, 170; as orthodox space, 23, 104-105; Palladius on, 24-25, 28, 104-105, 120-21, 124; Ps.-Martyrius on, 28, 104-105, 118; Socrates on, 143-44, 146-47, 152; Sozomen on, 164; and Theophilus, 88-92

Constantinus, 4

Constantius II, 4, 38, 40-44, 48, 59, 62, 72, 80, $140-41,146-47,152,155,159,164-65$

Constantius Gallus, 158-59, 162

Corsica, 97

countercouncil, 4, 129-30

counterspace, 24, 53-54, 70, 161

Crispus, 139

Cyprian of Carthage: on flight, xiv-xv, 39-40, 176; On the Lapsed, xiii, xiv-xv, 115-116

Cyrrhus, 149

Damascus, 43, 45

Daphne, 85, 158-59, 162-63

David, 45-46, 73

Decian persecution, xiv, 159, 170

desert: Athanasius on, 32, 35, 38-40, 49-55, 70; in Christian imagination, 56; Gregory of Nazianzus on, 66, 68-69, 70, 72-74; Nitrian, $32,34-35,40,73,86 n 30,121 n 57$; Sozomen on, 166-67

Demophilus, 61, 62n27, 75, 165

Dio Chrysostom, 7, 13-14

Diocletian, 33, 35, 133-34

Diodore, 78

Dioscorus, 86n3o

disease, gastrointestinal, 106-7, 112-13, 116

displacement: exile as, 23; theories of, 22-25

Domitian, 7, 13

Donatists, xiv

Dorotheus, 169 
East, the, 4, 136, 141, 147, 152, 159, 169

Easter, 38, 40

Easter Vigil, 128

Eastern Roman Empire, 29, 60, 122, 133, 141, 161 ecclesiastical historians, 148. See also Eusebius of Caesarea, Philostorgius of Cappadocia, Socrates of Constantinople, Sozomen of Constantinople, Theodoret of Cyrrhus

Edict of Milan, $35 \mathrm{n} 18$

edict of toleration, 134, 169

Egypt, 33-34, 51, 67, 72, 88-89, 128, 164

Elijah, 16, 45, 67, 110

Epiphanius of Salamis, 86n28, 108n15, 114, 168

Epistle to Diognetus, 15

epistolography, 25, 101

eremos, 51 . See also desert

eschatia, 50-51

Eucharist, 115-17

Eudoxia, 88, 92, 106, 108-17

Eudoxius, 79-80, 149, 155, 163-64

Euripides, 113n37, 114n38

Eusebians, 62, 136, 145, 150

Eusebius of Caesarea, 4-5, 134, 148, 151, 166; Life of Constantine, 135

Eusebius of Nicomedia, 152, 177; and Arius, 138; as bishop of Constantinople, 61-62; exile, 29, 137-38, 141, 147-48, 152; Letter to Arius, 138; Letter to Paulinus of Tyre, 138; Letter of Recantation, 138; life, 136-38; memory of, 133, 139; Philostorgius on, 141; Socrates on, 142-48; Theodoret on, 150-51

Eusebius of Vercelli, 161

Eustathius of Antioch, 64, 79, 140, 148-51, 155, $162,165-66$

Eutropius, 78, 108, 123

Euzoius, 80, 156-57, 163-64, 166, 168

Evagrius of Constantinople, 165-66

Evagrius of Pontus, 8

Eve, 110-111

Evethius, 94

exile: as alternative to death penalty, 5 ; as ascetic wandering, 8-9; and conformity, 1; difficult to reconstruct, 2, 4-5; as displacement, 23; exilium, 5-7; and heresiology, 17-22, 125, 176; and migrant, 174-75; models of, 16 ; as objective observer, 174-75; and orthodoxy, 125, 176; and postmodernity, 173-75; studies of, 5-15; terms for, 7-9; xeniteia, 8

exile (of individuals): Athanasius, 2-5, 32, 37, $42-44,72-73,125-27,130,162,164-65$, 175-77; Eusebius of Nicomedia, 29, 137-38, 141, 147-48, 152; Eustathius, 79, 162; Hilary of Poitiers, 18-20; John Chrysostom, 27-28, 76-78, 90, 93-102, 108, 119-121, 123-124, 128-30; Meletius of Antioch, 29, 80-83, 156-57, 164, 172; Sabbatius, 170-71; Theodoret of Cyrrhus, 149

fathers: ascetic, 8 ; of the church, 44-47, 58, 87, 92, 104

Fausta, 139

Favorinus of Arelate, 96n58

Fermentius, 41

Flavian, 78, 83, 131, 149, 157, 167-69, 171

Flavius Josephus, 106

flight, xiii-xvi, 7-8; as ascetic withdrawal, 46, 48; Athanasius on, 40, 46-48; discourse of, 2-5; Gregory of Nazianzus on, 65-67; of the logos (Son), 47-48, 100

fuga, 7,9

Gainas, 105-106, 117

Galerius, 106-107, 134

Gaul, 2, 19-20, 137, 145, 150

Gemellius, 95

George of Cappadocia, 41, 44, 62, 71-72, 136, 140, 155

Gorgonia, 57

Gratian, 169

Gregory of Cappadocia, 4, 125-26, 136, 147, 155

Gregory of Nazianzus, 26-27, 76, 169; on askesis, $66,70,72-73$; career, 60-63; on the desert, 55, 65-66, 68-70, 72-74; on flight, 56, 64-67; In Praise of Athanasius, 63, 66, 69-75, 126; In Praise of Basil the Great, 63, 65-70, 74-75; life, 57-58

Gregory of Nyssa, 57-58, 65, 81; Encomium on His Brother Basil, 65

Gregory of Tours, 19

Hagia Sophia, 59, 91

Heidegger, Martin, 174

Helena, 140, 144

Helenopolis, 136n15, 146

Heracles, 16, 109n22, 113-14

heresy: and exile, 17-22; as disease, 107-108, 114. See also Arianism, Arians

Herod Agrippa, 106

Herodias, $108 \mathrm{n} 17$

heterotopia, 24, 53-54, 70, 161

Hilary of Poitiers, 8, 18, 161; exile, 18-20

hippodrome, 93, 118

homoian, 61, 80

homoiousian, 141 
homoousion, 168

homoousios, 133, 142

Horace, 13

hydra, 113-14

Ignatius, 160

Illyricum, 151

Innocent I, 77, 85-87, 89-91, 93-94, 120

Iolaos, 114

Irene, 143,146

Isaac, 93

Isidore of Seville, 9

Israelites, 67

Jacob, 16, 45, 99

Jason, 16

Jehoram, 110

Jerome, 8, 20, 52

Jerusalem: Christ in, 74, 175; council, 4; holy cross in, 144; Jewish Temple, 163; Synod of, 148

Jezebel, 45, 108, 110

Job, 98

John Cassian, 8, 19

John Chrysostom, 100-102; and Athanasius,

124-31; biographers of, 104-6, 109-24, 127-31; and Constantinople, 24-25, 27, 76, 78-79, 85-91, 93-96, 101-102, 118-19, 124; correspondence in exile, 94-96, 101; Discourses against Judaizing Christians, 84; Epistle 173, 94-95; exile, 27-28, 76-78, 90, 93-102, 108, 119-21, 123-24, 128-30; and flight, 83-84; Letter to Innocent I, 86-92, 101; life and career, 76-78; and Meletius of Antioch, 157, 167-68, 171; No Man Can Be Harmed, 96-98, 101; On Babylas against Julian and the Pagans, 158, 160; On St. Babylas, 158-6o; On St. Meletius, 81-84; orthodox legacy of, 20-22, 29; Socrates of Constantinople on, 169, 171; Sozomen on, 171; and Theophilus of Alexandria, 86-92; To Those Who Are Tempted, 96-101; and urban space, 84-85, 93

Jovian, 163, 165-66

Judas Iscariot, 98, 107

Julian, 20, 59, 68, 80, 137, 157-65

Julius Caesar, 5

Julius Julianus, 113n36, 136

Justinian, 6

Kellia, 35n15

Lactantius, 106-107, 133-34

Lazarus, 98
Lernean hydra, 113-14

Leto, 110

Libanius of Antioch, 77, 158

Licinius, 134-37, 144

Logos, 47,100

Lucian of Antioch, 136, 140

Lucius of Alexandria, 166-67

Lucius the Greek, 128

Luke, 59,140

Lycopolis, 35

Macarius the Great, 8

Macedonius I, 61-62, 71, 146

Magnetius, 38

Manichean, 44, 125

Marcus Claudius Marcellus, 12

Maris of Chalcedon, 142

Marius Victorinus, 31

Mark, 72

Martyrdom of Polycarp, xv

martyrium, 160

Matrona, 85

Maximinus, 36, 66

Melania the Elder, 86n3o

Meletius of Alexandria, 35-36

Meletius of Antioch, 63-65, 77-84, 154, 177; and Babylas, 160-61; death, 81, 83-84; exile, 29, 8o-83, 156-57, 164, 172; and John Chrysostom, 157, 167-68, 171; Theodoret on, 155-57; Socrates of Constantinople on, 168-69, 171-72; Sozomen on, 169, 172

Melitians, 3, 70, 78, 80-81, 145, 156, 171

migrant, $174-75$

Milan, 18; Edict of, $35 \mathrm{n} 18$

Moses, 45-46, 99, 102

Nectarius, 78

Nero, 8, 106

Nestorian controversy, 149

New Rome, 58n6, 87, 143

Nicaea, 36, 58, 64, 66, 69-71, 74-75, 132-33; canons of, 63, 88-89, 92, 111n28; Council of, $36,37,64,71,79,87-88,136,148,162$; Nicene Creed, 149, 155, 163, 168

Nicomedes I, 133

Nicomedia, 23, 59, 69, 133-36, 139, 141, 148; earthquake in, 141; Socrates on, 142-43, 146-47

Niobe, 110

Nitrian: desert, 32, 34-35, 40, 86n3o, 121n57; monks, 88-89, 120-21

Nonna, 57

nonplace, 118 
North Africa, 35

Novatian, 164, 170

Odysseus, 12, 14, 16, 42, 99, 102

Oedipus, 42, 99, 102

Olympias, 27, 95-97, 101, 121-22

Origenist controversy, 88, 104, 106, 120-22, 124, 168

Origen of Alexandria, 57

Ovid, 7, 9, 12-13, 95, 110

Palestine, 36, 57

Palladius of Helenopolis, 24-25, 28, 86, 91, 103104; Dialogue on the Life of John Chrysostom, 86, 119-24, 127-30; Lausiac History, 120

pathos, 99

Patroclus, 16

Paul I, 61-62, 146

Paul (apostle), 16, 43, 45, 65

Paulinus, 63-65, 8o-81, 83, 157, 164, 168-69

peregrinatio, 7,9

persecution, xiii-xiv, 1-2, 9-10, 24, 35-36, 75, 116, 162, 166-67, 176; Athanasius on, 37, 42-49; Basil of Caesarea on, 68; Decian, 159, 170; destruction of buildings, 134n7; under Diocletian, 35, 134; Great, 35n18, 134, 162; John Chrysostom on, 27, 83, 101; under Maximinus, 66; in Nicomedia, 134-35, 142, 148; Palladius on, 123; Ps.-Martyrius on, 118; Sozomen on, 162; under Valens, 166

pharaoh, 45, 115

Pheretime, 109n2o

Pherme, 35n15

Philagrius, 128n67

Philip of Side, $105 n_{5}$

Philo, 15

Philocalia, 57

Philostorgius of Cappadocia, 136, 139-41; Ecclesiastical History, 140

Phrygia, 18

place, theories of, $23-25,176-77$

Plato, 85n27

Plutarch, 15

politeia, 48n40; Athanasius on, 32, 48-49, 54-55, 73; John Chrysostom on, 85, 93; Palladius on, 120

Polycarp, xv

Pontus, 66-67, 122

Porphyry, 16n56, 50n47, 135n8

postmodernity, 173-75

Pricus, 139 n26

Ps.-Martyrius, 28, 103-104; Funerary Speech, 105-18, 127-30

psychagogy, 107n14 return, 28; of Arius, 145; of Athanasius, 2, 4, 55, $70,73-74,126,129,148,162,165$; of Basil of Caesarea, 68-69; of Cicero, 12; of Eusebius of Nicomedia, 29, 137-38, 141, 144, 148, 152; Gregory of Nazianzus on, 56-57, 65-66, 68-70, 73-75; of Hilary of Poitiers, 20; illegal, 143; and John Chrysostom, 28, 77, 83, 96, 100-101, 104-5, 110-11, 118, 124, 127-30; of Meletius, 80, 82-83, 164, 169,171

Rhodes, 171

Rimini, 141

Rome, 87, 101

Rufinus of Aquileia, 86n3o, $151 n_{48}$

Sabbatius, 170-71

Salustius, 95

Sasima, 60, 63

Saturninus, 19n71

Scetis, $32 \mathrm{n}_{5}$

Second Punic War, 5

Second Sophistic, 96

Secundus of Ptolemais, 142

Seleucia, 60

self-exile, 8

Seneca the Younger, 7, 97; Consolations, 97

Septimius Severus, 33

Serapeum, 34n10

Serapian, 122

Severianus of Gabala, 108 n19

Silvanus, 19

Socrates, $\mathrm{xV}$

Socrates of Constantinople, 6o-61, 80, 108, 137-38, 141-48, 152, 167-72; Ecclesiastical History, 21, 141-42

Soma, 33

Sozomen of Constantinople, 61, 78, 108, 137-38, 161-67, 169-72; Ecclesiastical History, 21, 161

space, theories of, 22-25, 176-77

Stoicism, 97, 99-100

subintroductae, 93

Sulpicius Severus, 19, 20

Syene, 119

Synod of the Oak, 97, 127-28, 130

Tall Brothers, 88, 106, 121n57, 122, 167

Temple of Apollo, 85, 158-6o, 163

Tertullian of Carthage: on flight, xiii-xiv, 39-40, 176; On Flight in Persecution, xiii-xiv

Thebes, 42, 110, 142

Themistius, $58 \mathrm{n} 6$

Theodore, 163 
Theodoret of Cyrrhus, 8o, 138, 149-52; Ecclesiastical History, 132, 149, 151; exile, 149

Theodosian Code, 6

Theodosius I, 59-60, 169

Theodosius II, 164

Theognis of Nicaea, 137, 142-43, 150

Theonas of Marmarica, 142

Theophilus of Alexandria, 27, 86-92, 95; Palladius on, 120-24, 127-28, 130;

Ps.-Martyrius on, 106, 127-28, 130

Timothy of Alexandria, 63, 79

Trier, 3-4, 37, 125

Trinitarian controversy, 79, 104
Trinity, 156

Tyre, Council of, 3-4, 145, 148-49

Valens, 68-69, 163-66

Valentinian I, 163, 165

Wadi el-Natrun, 32n5

wanderer, 41-42

West, the, 4, 141, 157, 161

Western Roman Empire, 26

xeniteia, 8

xenos, 14-15 
Flight during times of persecution has a long and fraught history in early Christianity. In the third century, bishops who fled were considered cowards or, worse yet, heretics. On the face, flight meant denial of Christ and thus betrayal of faith and community. But by the fourth century, the terms of persecution changed as Christianity became the favored cult of the Roman Empire. Prominent Christians who fled and survived became founders and influencers of Christianity over time.

Bishops in Flight examines the various ways these episcopal leaders both appealed to and altered the discourse of Christian flight to defend their status as purveyors of Christian truth, even when their exiles appeared to condemn them. Their stories illuminate how profoundly Christian authors deployed theological discourse and the rhetoric of heresy to respond to the phenomenal political instability of the fourth and fifth centuries.

"This exciting book offers the first sustained examination of flight during times of persecution. A significant contribution to the study of late antiquity that readers are sure to find highly stimulating." SUSANNA ELM, author of Sons of Hellenism, Fathers of the Church: Emperor Julian, Gregory of Nazianzus, and the Vision of Rome

"A fascinating meditative exploration of the shifting nature of exile and its uses in late ancient Christianity. Jennifer Barry depicts with lucid prose the adoptions and adaptations Christian bishops made of the concept in order to tap the authority exile could grant to those who managed it well. Those who study early church politics and imperial power will relish this book." ELLEN MUEHLBERGER, author of Moment of Reckoning: Imagined Death and Its Consequences in Late Ancient Christianity

JENNIFER BARRY is Assistant Professor of Religion at University of Mary Washington. A Joan Palevsky Book in Classical Literature

\section{UNIVERSITY OF CALIFORNIA PRESS}

www.ucpress.edu | www.luminosoa.org

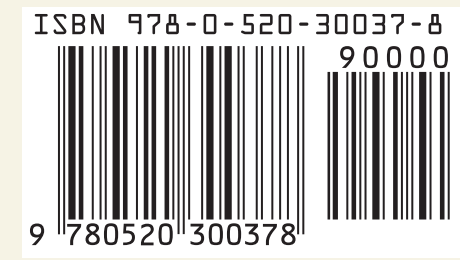

A free ebook version of this title is available through Luminos, University of California Press's Open Access publishing program for monographs. Visit www.luminosoa.org to learn more.

Cover illustration: Temptation of Christ (mosaic in basilica di San Marco), 12 th century. 